P.O. Box 98518

Las Vegas, NV 89193-8518

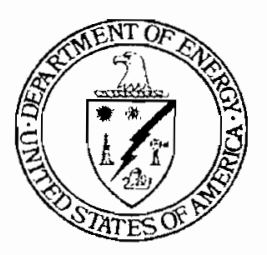

\title{
MAR 242009
}

Tim Murphy, Chief

Bureau of Federal Facilities

Division of Environmental Protection

2030 East Flamingo Road, Suite 230

Las Vegas, NV 89119-0818

SUBMITTAL OF THE FINAL POST-CLOSURE INSPECTION LETTER REPORT FOR CORRECTIVE ACTION UNITS ON THE NEVADA TEST SITE; REVISION 0, MARCH 2009

This letter serves as the post-closure inspection letter report for Corrective Action Units (CAUs) on the Nevada Test Site (NTS) for Calendar Year 2008.

\section{CAU 5, Landfills}

Eight Corrective Action Sites (CASs) in CAU 5 require inspections. CAS 05-15-01, CAS 05-16-01, and CAS 23-15-03 were inspected on November 25, 2008. CAS 06-08-01, CAS 06-15-02, and CAS 06-15-03 were inspected on November 13, 2008. CAS 12-15-01 was inspected on October 27, 2008. CAS 20-15-01 was inspected on October 28, 2008.

During the previous inspections performed for Calendar Year 2007, numerous signs were down, loose, or missing at CAS 05-15-01, CAS 05-16-01, CAS 06-08-01, and CAS 12-15-01. In addition, fences at CAS 06-08-01 and CAS 12-15-01 required repair. It was also recommended to replace the locks at CAS 06-08-01 and post an additional sign at CAS 06-08-01. Sign maintenance and additional repairs were completed in March and June of 2008.

During the 2008 inspections, several signs were down, loose, or missing due to high winds at CAS 05-15-01, CAS 05-16-01, CAS 06-08-01, and CAS 20-15-01. Sign maintenance will be completed in 2009 and reported in the next letter report. No other issues were identified.

\section{CAU 113, Area 25 R-MAD Facility}

CAU 113 was inspected on December 17, 2008. No issues were identified, and no maintenance or repairs were required.

\section{CAU 115, Area 25 Test Cell A Facility}

CAU 115 was inspected on December 17, 2008. During the inspection, several signs were down or missing. Sign maintenance will be completed in 2009 and reported in the next letter report. In addition, as a best management practice, it was recommended to reconfigure radiological postings to improve awareness of site conditions. No other issues were identified. 


\section{CAU 118, Area 27 Super Kukla Facility}

CAU 118 requires semiannual inspections. The site was inspected on October 9 and December 11, 2008. No issues were identified, and no maintenance or repairs were required.

\section{CAU 127, Areas 25 and 26 Storage Tanks}

Two CASs in CAU 127 require inspections. CAS 25-01-07 was inspected on December 8, 2008, and CAS 25-02-02 was inspected on December 9, 2008. No issues were identified, and no maintenance or repairs were required.

\section{CAU 137, Waste Disposal Sites}

Four CASs in CAU 137 require inspections. CAS 01-08-01 was inspected on November 13, 2008. CAS 07-23-02 was inspected on November 4, 2008. CAS 12-08-01 and CAS 12-23-07 were inspected on October 27, 2008. No issues were identified, and no maintenance or repairs were required.

\section{CAU 140, Waste Dumps, Burn Pits, and Storage Area}

Two CASs in CAU 140 require inspections. CAS 05-23-01 was inspected on November 13, 2008, and CAS 23-17-01 was inspected on November 25, 2008. During the previous inspections performed for Calendar Year 2007, one sign was down and one sign was loose at CAS 23-17-01. Sign maintenance was completed in August 2008. During the 2008 inspections, one sign was down at CAS 05-23-01. Sign maintenance will be completed in 2009 and reported in the next letter report. No other issues were identified.

\section{CAU 143, Area 25 Contaminated Waste Dumps}

Two CASs in CAU 143 require inspections. CAS 25-23-03 and CAS 25-23-09 were inspected on December 17, 2008. During the previous inspections performed for Calendar Year 2007, numerous signs and radiological postings were down, loose, or missing at CAS 25-23-09. Sign maintenance was completed in February 2008. During the 2008 inspections, several signs were down, loose, or missing at CAS 25-23-03 and CAS 25-23-09. Sign maintenance will be completed in 2009 and reported in the next letter report. No other issues were identified.

\section{CAU 145, Wells and Storage Holes}

CAU 145 was inspected on November 4, 2008. No issues were identified, and no maintenance or repairs were required.

\section{CAU 151, Septic Systems and Discharge Area}

CAU 151 was inspected on October 27, 2008. No issues were identified, and no maintenance or repairs were required.

\section{CAU 165, Area 25 and 26 Dry Well and Washdown Areas}

CAU 165 was inspected on December 3, 2008. During the inspection, one sign was down. Sign maintenance will be completed in 2009 and reported in the next letter report. No other issues were identified. 


\section{CAU 168, Area 25 and 26 Contaminated Materials and Waste Dumps}

Three CASs in CAU 168 require inspections. CAS 25-16-03 was inspected on December 8, 2008. CAS 25-23-02 was inspected on December 17, 2008. CAS 25-99-16 was inspected on December 3, 2008. During the previous inspections performed for Calendar Year 2007, several signs were down or loose at CAS 25-23-02. Sign maintenance was completed in March 2008. During the 2008 inspections, no issues were identified, and no maintenance or repairs were required.

\section{CAU 204, Storage Bunkers}

Five CASs in CAU 204 require inspections. CAS 01-34-01, CAS 02-34-01, and CAS 05-18-02 were inspected on November 13, 2008. CAS 03-34-01 was inspected on November 4, 2008. CAS 05-33-01 was inspected on November 25, 2008. During the previous inspections performed for Calendar Year 2007, T-post removal was recommended at CAS 05-18-02. T-post removal was completed in March 2008. During the 2008 inspections, one sign was down at CAS 02-34-01. Sign maintenance will be completed in 2009 and reported in the next letter report. No other issues were identified.

\section{CAU 254, Area 25 R-MAD Decontamination Facility}

CAU 254 was inspected on December 17, 2008. No issues were identified, and no maintenance or repairs were required.

\section{CAU 261, Area 25 Test Cell A Leachfield System}

CAU 261 was inspected on December 17, 2008. During the inspection, several signs were down or missing. Sign maintenance will be completed in 2009 and reported in the next letter report. No other issues were identified.

\section{CAU 262, Area 25 Septic Systems and UDP}

Three CASs in CAU 262 require inspections. CAS 25-02-06 was inspected on December 8, 2008. CAS 25-05-03 was inspected on December 10, 2008. CAS 25-05-08 was inspected on December 9, 2008. During the previous inspections performed for Calendar Year 2007, one sign was missing at CAS 25-05-08. Sign maintenance was completed in March 2008. During the 2008 inspections, one sign was down at CAS 25-05-03, and one sign was down at CAS 25-05-08. Sign maintenance will be completed in 2009 and reported in the next letter report. No other issues were identified.

\section{CAU 309, Area 12 Muckpiles}

The three CASs in CAU 309 that require inspections were inspected on October 27 and November 13,2008. During the previous inspections performed for Calendar Year 2007, several radiological postings were in poor condition. Sign maintenance was completed in June 2008. During the 2008 inspections, one T-post was loose. T-post repair will be completed in 2009 and reported in the next letter report. No other issues were identified. 


\section{CAU 322, Areas 1 \& 3 Release Sites and Injection Wells}

CAU 322 was inspected on November 4, 2008. During the inspection, one sign was down. In addition, the fence had been removed to facilitate demolition of the building that was located within the use restricted area. Sign maintenance and fence installation will be completed in 2009 and reported in the next letter report. No other issues were identified.

\section{CAU 339, Area 12 Fleet Operations Steam Cleaning Effluent}

CAU 339 was inspected on October 27, 2008. No issues were identified, and no maintenance or repairs were required.

\section{CAU 357, Mud Pits and Waste Dump}

Three CASs in CAU 357 require inspections. CAS 04-26-03 was inspected on November 13, 2008. CAS 10-09-06 was inspected on November 4, 2008. CAS 25-15-01 was inspected on December 8, 2008. No issues were identified, and no maintenance or repairs were required.

\section{CAU 528, Polychlorinated Biphenyls Contamination}

CAU 528 was inspected on December 9, 2008. During the previous inspection performed for Calendar Year 2007, three signs were down. Sign maintenance was completed in March 2008. During the 2008 inspection, numerous signs were down, loose, or missing. Sign maintenance will be completed in 2009 and reported in the next letter report. No other issues were identified.

\section{CAU 529, Area 25 Contaminated Materials}

CAU 529 was inspected on December 10, 2008. During the previous inspection performed for Calendar Year 2007, one sign was down. Sign maintenance was completed in June 2008. During the 2008 inspection, one sign was down. Sign maintenance will be completed in 2009 and reported in the next letter report. No other issues were identified.

\section{CAU 542, Disposal Holes}

The five CASs in CAU 542 that require inspections were inspected on November 4, 2008. During the previous inspections performed for Calendar Year 2007, one sign was down at CAS 03-20-07, and one sign was loose at CAS 03-20-10. Sign maintenance was completed in April 2008. During the 2008 inspections, several signs were down, missing, or faded at CAS 03-20-07, CAS 03-20-09, CAS 03-20-10, CAS 03-20-11, and CAS 06-20-03.

Sign maintenance will be completed in 2009 and reported in the next letter report. No other issues were identified.

\section{CAU 543, Liquid Disposal Units}

Three CASs in CAU 543 require inspections. CAS 06-07-01 was inspected on November 13, 2008. CAS 15-01-03 and CAS 15-23-03 were inspected on November 4, 2008. During the inspections, the polychlorinated biphenyl labels were faded at CAS 06-07-01, and it was recommended to replace the labels. Replacement of labels will be completed in 2009 and reported in the next letter report. No other issues were identified. 


\section{CAU 545, Dumps, Waste Disposal Sites, and Buried Radioactive Materials}

The two CASs in CAU 545 that require inspections were inspected on November 4, 2008. No issues were identified, and no maintenance or repairs were required.

\section{CAU 551, Area 12 Muckpiles}

CAU 551 was inspected on October 27, 2008. During the previous inspection performed for Calendar Year 2007, one sign was down. Sign maintenance was completed in June 2008. During the 2008 inspection, it was noted that one of the two shunts had eroded, allowing runoff down the road. Shunt repair will be completed in 2009 and reported in the next letter report. No other issues were identified.

\section{CAU 552, Area 12 Muckpile and Ponds}

CAU 552 was inspected on October 27, 2008. During the previous inspection performed for Calendar Year 2007, the fence was loose. Fence repair was completed in June 2008. During the 2008 inspection, no issues were identified, and no maintenance or repairs were required.

\section{CAU 554, Area 23 Release Site}

CAU 554 was inspected on November 25,2008. During the inspection, one sign was missing. Sign maintenance will be completed in 2009 and reported in the next letter report. No other issues were identified.

\section{DEFENSE THREAT REDUCTION AGENCY SITES}

The following use restrictions are associated with CAUs that were closed by the Defense Threat Reduction Agency (DTRA). A formal transfer of these sites from DTRA to the U.S. Department of Energy, National Nuclear Security Administration Nevada Site Office (NNSA/NSO) is being considered. Results of these inspections are included in this report on behalf of DTRA.

\section{CAU 383, Area 12 E-Tunnel Sites}

CAU 383 was inspected on October 27, 2008. No issues were identified, and no maintenance or repairs were required.

\section{CAU 476, Area 12 T-Tunnel Muckpile, and CAU 559, T-Tunnel Compressor/Blower Pad} CAU 476 and CAU 559 were inspected on December 11, 2008. During the inspection, the wording on the signs was noted to be inconsistent with the wording required by the Closure Report. It was recommended to replace the signs. The signs will be replaced in 2009 and reported in the next letter report. No other issues were identified.

\section{CAU 477, Area 12 N-Tunnel Muckpile}

CAU 477 was inspected on December 11,2008. During the inspection, the wording on the signs was noted to be inconsistent with the wording required by the Closure Report. It was recommended to replace the signs. The signs will be replaced in 2009 and reported in the next letter report. No other issues were identified. 


\section{CAU 478, Area 12 T-Tunnel Ponds}

CAU 478 was inspected on December 16, 2008. During the inspection, the wording on the signs was noted to be inconsistent with the wording required by the Closure Report. It was recommended to replace the signs. The signs will be replaced in 2009 and reported in the next letter report. No other issues were identified.

\section{CAU 482, Area 15 U15a/e Muckpiles and Ponds}

CAU 482 was inspected on December 9, 2008. During the inspection, the wording on the signs was noted to be inconsistent with the wording required by the Closure Report. It was recommended to replace the signs. The signs will be replaced in 2009 and reported in the next letter report. No other issues were identified.

Due to the large number of signs each year that require replacement at various CAUs on the NTS, NNSA/NSO has begun transitioning to the use of heavier duty sign posts and more effective attachments of the signs to these posts. This effort started at sites located in high-wind areas, but will be expanded to include all future signs that need to be replaced beginning in Calendar Year 2010. This is expected to significantly reduce the number of sign replacements required in the future.

Copies of completed inspection checklists are attached. Please direct comments and questions to Tiffany Lantow, of my staff, at (702) 295-7645.

ERP:5014.TL

Original signed by: $R$ Boehlecke

Robert F. Boehlecke

Federal Project Director

Environmental Restoration Project

Enclosures:

As stated 
Nevada

Environmental

Restoration

Project

\section{ENCLOSURE:}

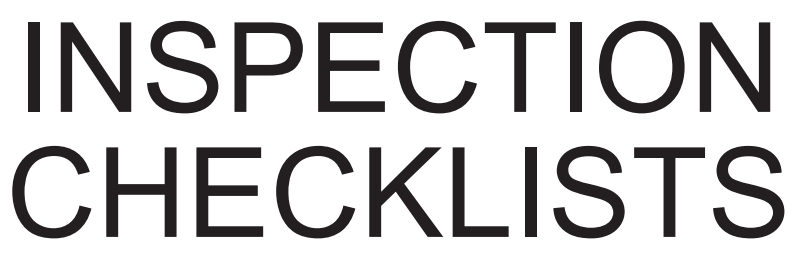

Post-Closure Inspection Letter Report for Corrective Action Units on the Nevada Test Site

\section{Calendar Year 2008}

March 2009

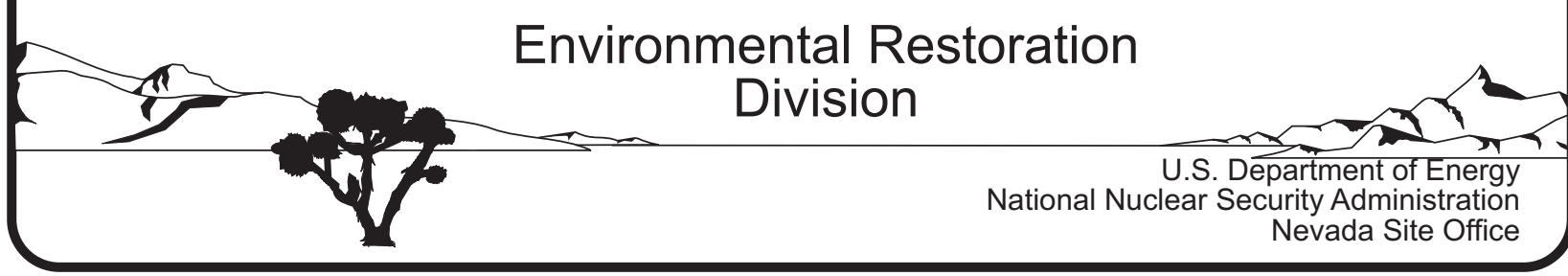


THIS PAGE INTENTIONALLY LEFT BLANK 
CAU 5: LANDFILLS 
THIS PAGE INTENTIONALLY LEFT BLANK 


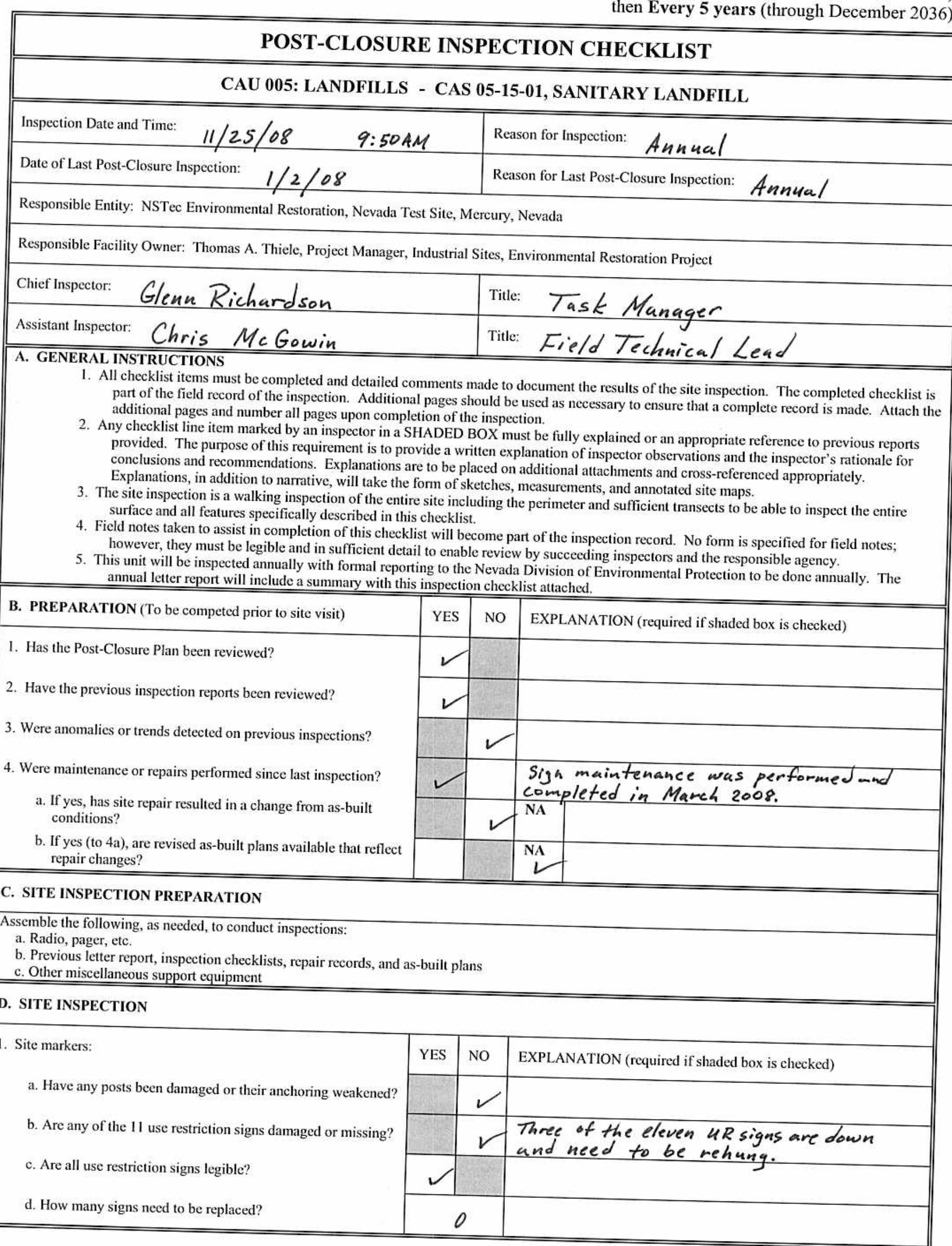




\section{POST-CLOSURE INSPECTION CHECKLIST \\ CAU 005: LANDFILLS - CAS 05-15-01, SANITARY LANDFILL}

2. Waste unit covers:

a. Is there evidence of settling?

b. Is there evidence of erosion (wind or water)?

c. Is there evidence of human intrusion onto the site?

d. Is there evidence of large animal intrusion onto the site?

3. Photograph Documentation (optional):

a. Have photographs been taken of the site?

If yes, how many photos were taken?

If yes, has a photographic $\log$ been prepared?

\begin{tabular}{|c|c|c|c|}
\hline E. FIELD CONCLUSIONS & YES & NO & EXPLANATION (required if shaded box is checked) \\
\hline $\begin{array}{l}\text { 1. Is there an imminent hazard to the integrity of the site? } \\
\text { (Immediate report required) }\end{array}$ & & & \\
\hline
\end{tabular}

Date reported:

Person/Agency to whom report was made:

2. Are more frequent inspections required?

3. Are existing maintenance/repair actions satisfactory?

4. Is other maintenance/repair necessary?

5. Field conclusions/recommendations: Noticed 3 UR signs down that need to be rehung. No evidence of settling or erosion noticed on the
landfill cover.

\section{F. CERTIFICATION}

I have conducted an inspection of CAS 05-15-01, Sanitary Landfill, in accordance with the procedures of the Post-Closure Plan as recorded on this checklist,
attached sheets, field notes, photographs, and photograph logs. attached sheets, field notes, photographs, and photograph logs.

Chief Inspector's Signature: /s/ $\overrightarrow{\mathrm{G}}$ Richardson 


\section{POST-CLOSURE INSPECTION CHECKLIST}

\section{CAU 005: LANDFILLS - CAS 05-16-01, LANDFILL}

\begin{tabular}{||l|l||}
\hline \hline Inspection Date and Time: $11 / 25 / 08 \quad 1 / 06 \mathrm{Am}$ & Reason for Inspection: Ann $\mathrm{n} /$ \\
\hline Date of Last Post-Closure Inspection: $1 / 23 / 08$ & Reason for Last Post-Closure Inspection: Ann $\mathrm{Aa} / \mathrm{A}$ \\
\hline
\end{tabular}

Responsible Entity: NSTec Environmental Restoration, Nevada Test Site, Mercury, Nevada

Responsible Facility Owner: Thomas A. Thiele, Project Manager, Industrial Sites, Environmental Restoration Project

\section{Chief Inspector: Glenn Richardson}

Assistant Inspector: Chris Mc Gowin

\section{A. GENERAL INSTRUCTIONS}

1. All checklist items must be completed and detailed comments made to document the results of the site inspection. The completed checklist is part of the field record of the inspection. Additional pages should be used as necessary to ensure that a complete record is made. Attach the additional pages and number all pages upon completion of the inspection.

2. Any checklist line item marked by an inspector in a SHADED BOX must be fully explained or an appropriate reference to previous reports provided. The purpose of this requirement is to provide a written explanation of inspector observations and the inspector's rationale for conclusions and recommendations. Explanations are to be placed on additional attachments and cross-referenced appropriately. Explanations, in addition to narrative, will take the form of sketches, measurements, and annotated site maps.

3. The site inspection is a walking inspection of the entire site including the perimeter and sufficient transects to be able to inspect the entire surface and all features specifically described in this checklist.

4. Field notes taken to assist in completion of this checklist will become part of the inspection record. No form is specified for field notes; however, they must be legible and in sufficient detail to enable review by succeeding inspectors and the responsible agency.

5. This unit will be inspected annually with formal reporting to the Nevada Division of Environmental Protection to be done annually. The annual letter report will include a summary with this inspection checklist attached.

\begin{tabular}{|c|c|c|c|}
\hline B. PREPARATION (To be competed prior to site visit) & YES & NO & EXPLANATION (required if shaded box is checked) \\
\hline \multicolumn{4}{|l|}{ 1. Has the Post-Closure Plan been reviewed? } \\
\hline \multicolumn{4}{|l|}{ 2. Have the previous inspection reports been reviewed? } \\
\hline \multicolumn{4}{|l|}{ 3. Were anomalies or trends detected on previous inspections? } \\
\hline 4. Was maintenance or repairs performed since last inspection? & & & $\begin{array}{l}\text { Sign maintenance was completed in March zoo } \\
\text { on the east of the berm. }\end{array}$ \\
\hline $\begin{array}{l}\text { a. If so, has site repair resulted in a change from as-built } \\
\text { conditions? }\end{array}$ & & & NA \\
\hline $\begin{array}{l}\text { b. If yes (to } 4 a \text { ), are revised as-built plans available that reflect } \\
\text { repair changes? }\end{array}$ & & & NA \\
\hline
\end{tabular}

\section{SITE INSPECTION PREPARATION}

Assemble the following, as needed, to conduct inspections:

a. Radio, pager, etc.

b. Previous letter report, inspection checklists, repair records, and as-built plans

c. Other miscellaneous support equipment

\section{SITE INSPECTION}

1. Site markers East of Berm:

a. Have any posts been damaged or their anchoring weakened?

b. Are any of the use restriction signs damaged or missing?

c. Are all use restriction signs legible?

d. How many signs need to be replaced? 


\section{POST-CLOSURE INSPECTION CHECKLIST}

\section{CAU 005: LANDFILLS - CAS 05-16-01, LANDFILL}

2. Waste unit cover East of Berm:

a. Is there evidence of settling?

b. Is there evidence of erosion (wind or water)?

c. Is there evidence of human intrusion into the cover?

d. Is there evidence of large animal intrusion into the cover?

3. Site markers West of Berm

a. Is there damage to the fence?

b. Have any posts been damaged or their anchoring weakened?

c. Are any of the use restriction signs damaged or missing?

d. Are all use restriction signs legible?

e. How many signs need to be replaced?

4. Waste unit cover West of Berm:

a. Is there evidence of settling?

b. Is there evidence of erosion (wind or water)?

c. Is there evidence of human intrusion into the cover?

d. Is there evidence of large animal intrusion into the cover?

5. Photograph Documentation (optional):

a. Have photographs been taken of the site?

If yes, how many photos were taken?

If yes, has a photographic log been prepared?

\section{E. FIELD CONCLUSIONS}

1. Is there an imminent hazard to the integrity of the site? (Immediate report required)

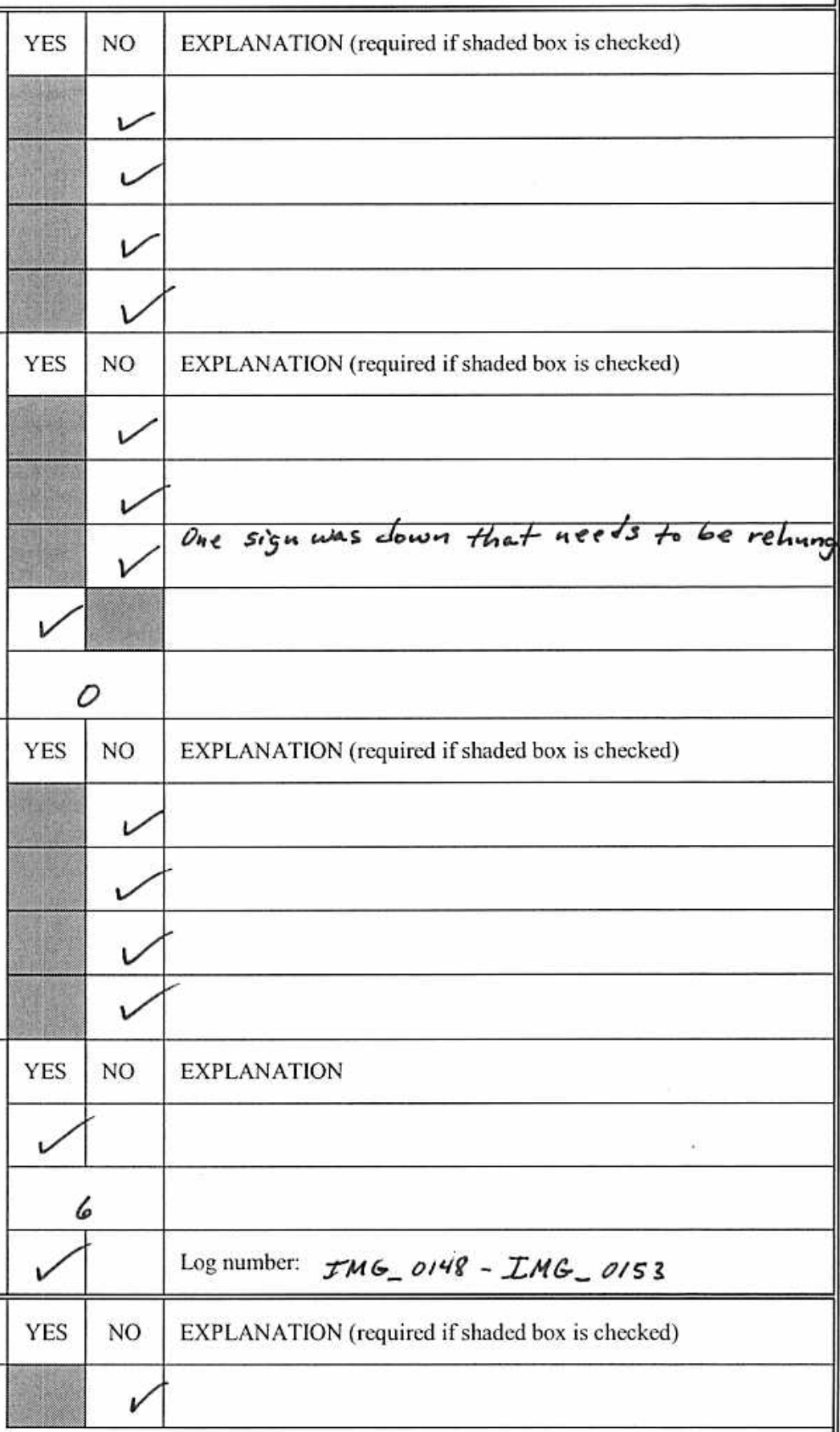

Date reported:

Person/Agency to whom report was made:

2. Are more frequent inspections required?

3. Are existing maintenance/repair actions satisfactory?

4. Is other maintenance/repair necessary? 


\begin{tabular}{|c|c|}
\hline \multicolumn{2}{|c|}{ POST-CLOSURE INSPECTION CHECKLIST } \\
\hline \multicolumn{2}{|c|}{ CAU 005: LANDFILLS - CAS 05-16-01, LANDFILL } \\
\hline \multicolumn{2}{|c|}{$\begin{array}{l}\text { 5. Field conclusions/recommendations: One GR sign on the east and west side of the } \\
\text { berm is down and needs to be rehung. The inspection was performed } \\
\text { with an escont from Area } 5 \text { RwMS. It was determined that the }\end{array}$} \\
\hline \multicolumn{2}{|c|}{$\begin{array}{l}\text { minor sign maintenance would be coordinated and completed by } \\
\text { Area } S \text { RWMS support personnel. }\end{array}$} \\
\hline \multicolumn{2}{|l|}{ F. CERTIFICATION } \\
\hline \multicolumn{2}{|c|}{$\begin{array}{l}\text { I have conducted an inspection of CAS 05-16-01, Landfill, in accordance with the procedures of the Post-Closure Plan as recorded on this checklist, attached } \\
\text { sheets, field notes, photographs, and photograph logs. }\end{array}$} \\
\hline Chief Inspector's Signature: /s/ G Richardson & Date: $\quad 11 / 25 / 08$ \\
\hline Printed Name: Glenn Richardson & Title: Task Manager \\
\hline
\end{tabular}




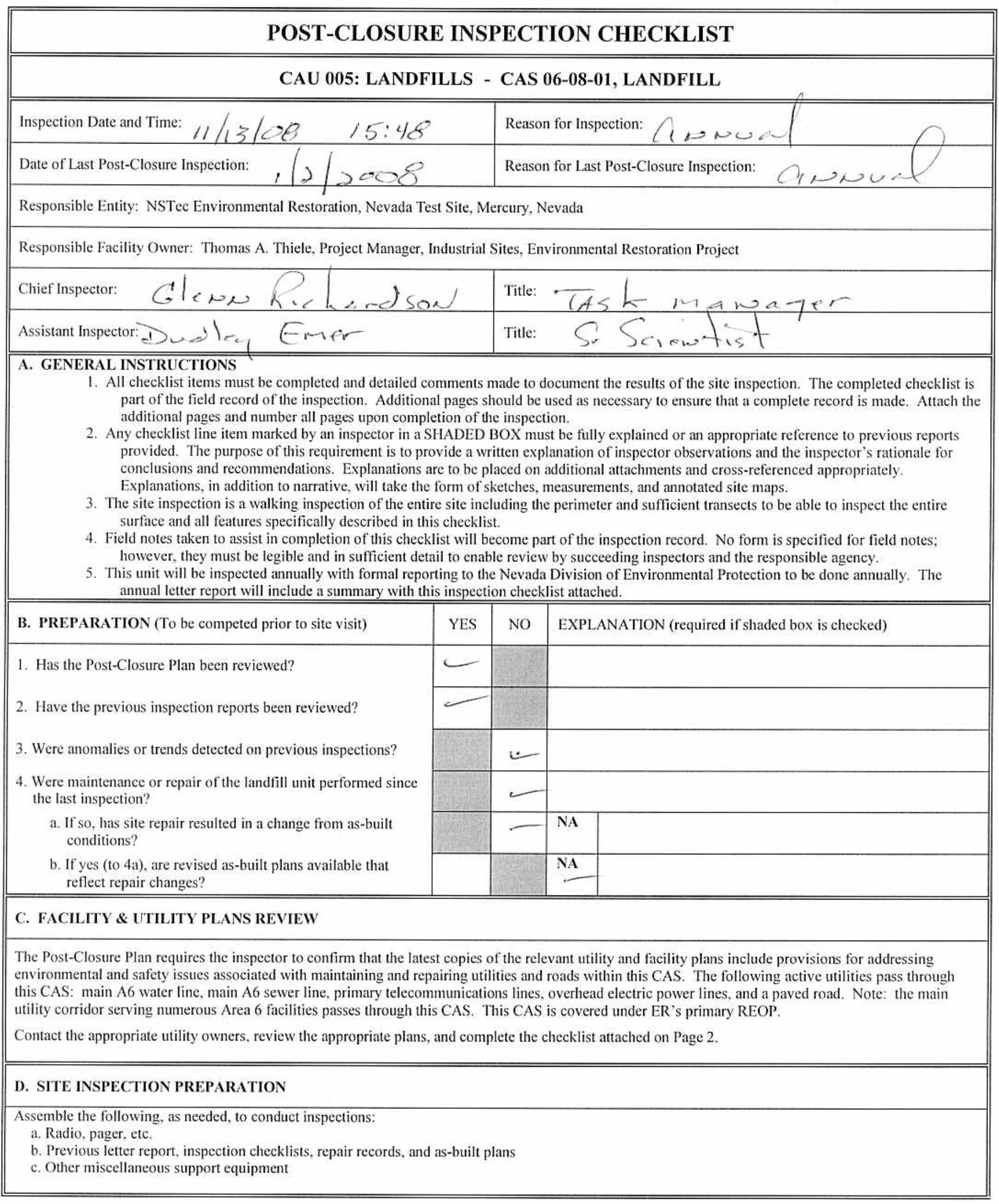




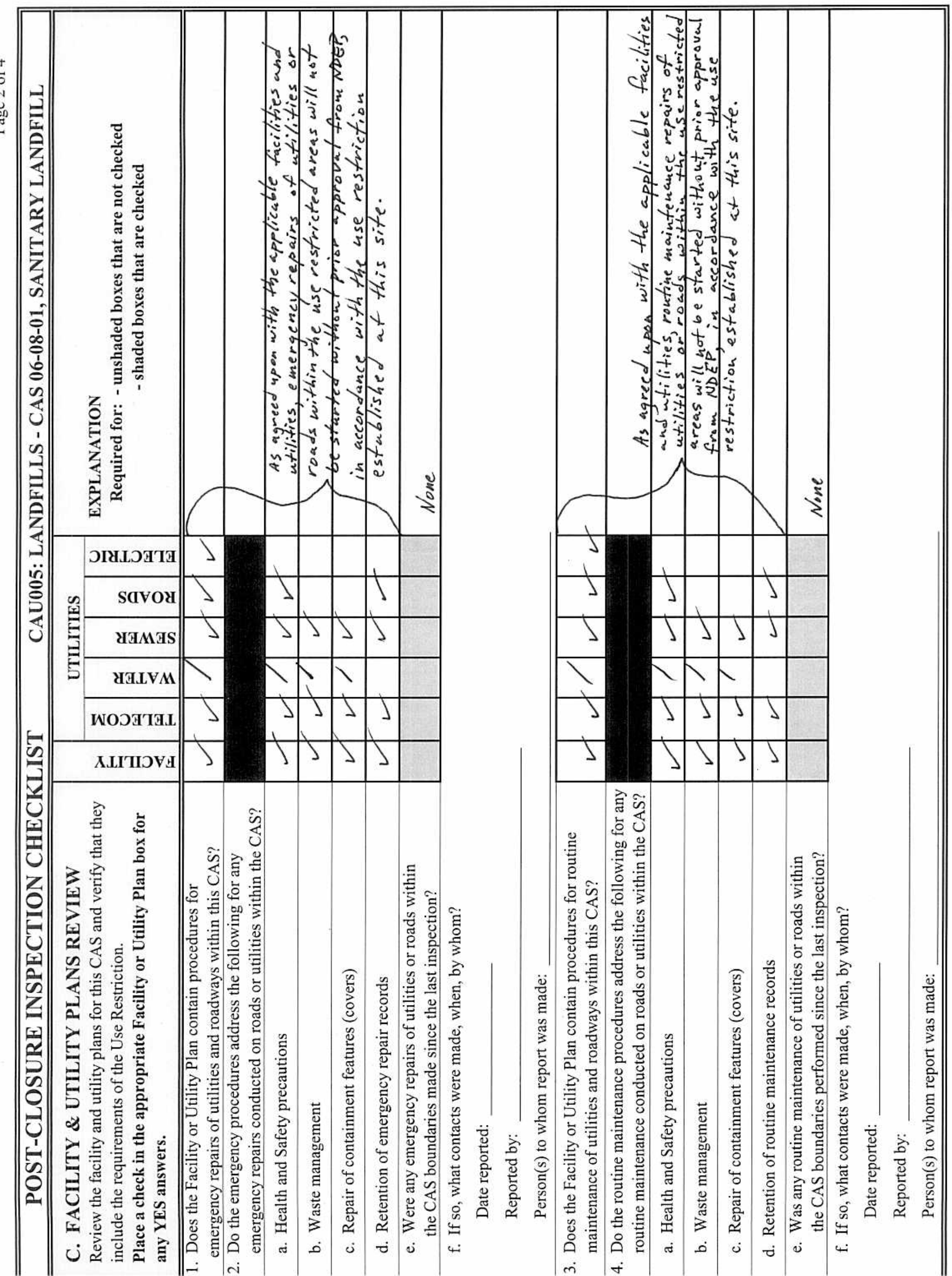




\section{POST-CLOSURE INSPECTION CHECKLIST}

\section{CAU 005: LANDFILLS - CAS 06-08-01, LANDFILL}

\section{E. SITE INSPECTION}

1. Site markers around fenced area:

a. Is there damage to the gates?

b. Are the gate locks in place and functional?

c. Is there damage to the fence?

d. Have any posts been damaged or their anchoring weakened?

e. Are any of the use restriction signs damaged or missing?

f. Are all use restriction signs legible?

g. How many signs need to be replaced?

2. Waste unit cover in fenced area:

a. Is there evidence of settling?

b. Is there evidence of erosion (wind or water)?

c. Is there evidence of human intrusion into the cover?

d. Is there evidence of large animal intrusion into the cover?

3. Site markers from south boundary of use restricted area to fence:

a. Have any posts been damaged or their anchoring weakened?

b. Are any of the use restriction signs damaged or missing?

c. Are all use restriction signs legible?

d. How many signs need to be replaced?

4. Waste unit cover from south boundary of use restricted area to fence:

a. Is there evidence of settling?

b. Is there evidence of erosion (wind or water)?

c. Is there evidence of human intrusion into the cover?

d. Is there evidence of large animal intrusion into the cover?

5. Photograph Documentation (optional):

a. Have photographs been taken of the site?

If yes, how many photos were taken?

If yes, has a photographic log been prepared?

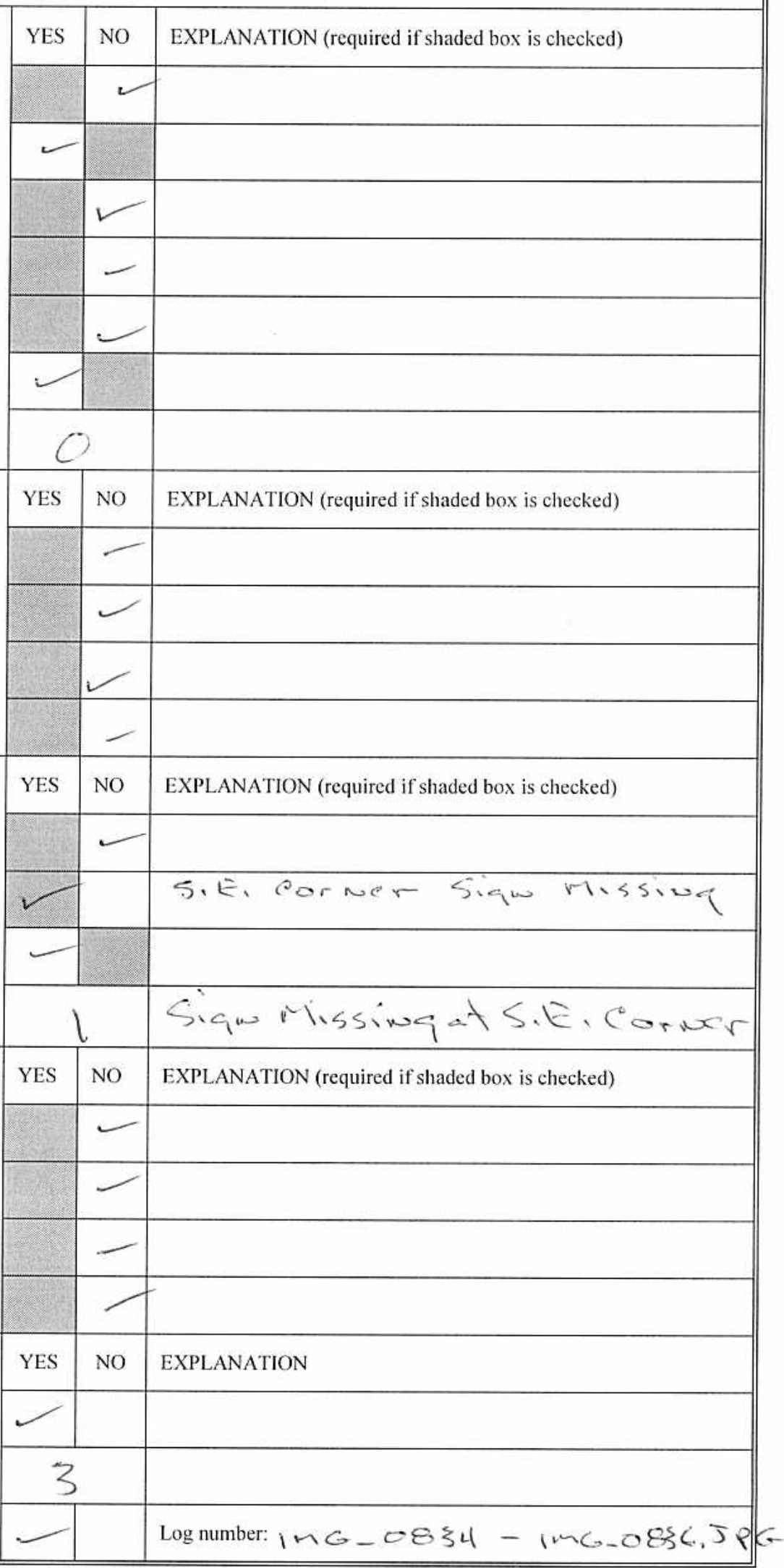




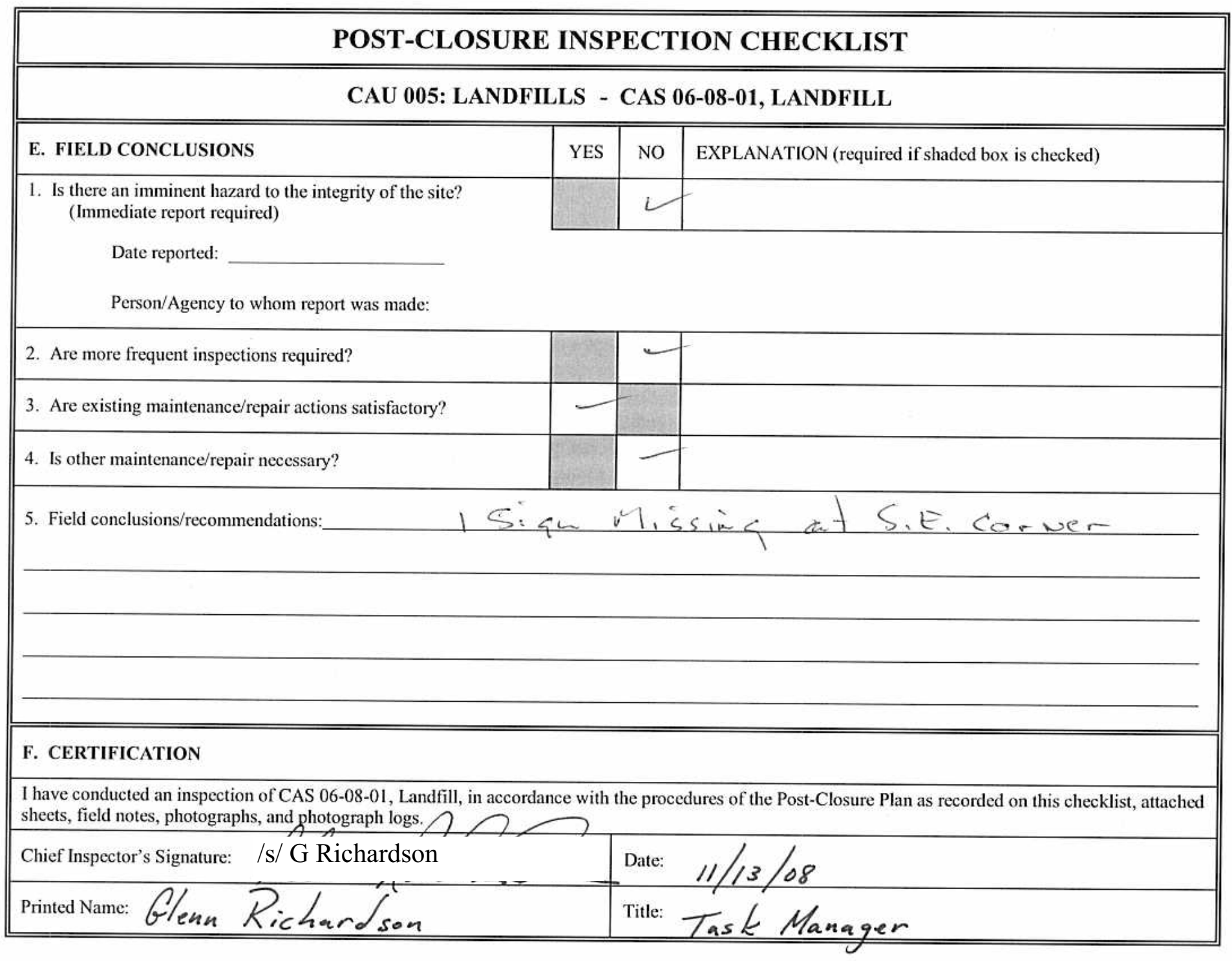




\begin{tabular}{|c|c|}
\hline \multicolumn{2}{|c|}{ POST-CLOSURE INSPECTION CHECKLIST } \\
\hline \multicolumn{2}{|c|}{$\begin{array}{l}\text { CAU 005: LANDFILLS - CAS 06-15-02, SANITARY LANDFILL } \\
\text { CAS 06-15-03, SANITARY LANDFILL, BURN PIT } \\
\end{array}$} \\
\hline Inspection Date and Time: $11 / 13 / 08$ & Reason for Inspection: $\left.C_{1}, N \cup C\right)$ \\
\hline Date of Last Post-Closure Inspection: $1 / 2 / 2008$ & Reason for Last Post-Closure Inspection: $C_{*}$ u \\
\hline
\end{tabular}

Responsible Entity: NSTec Environmental Restoration, Nevada Test Site, Mercury, Nevada

Responsible Facility Owner: Thomas A. Thiele, Project Manager, Industrial Sites, Environmental Restoration Project

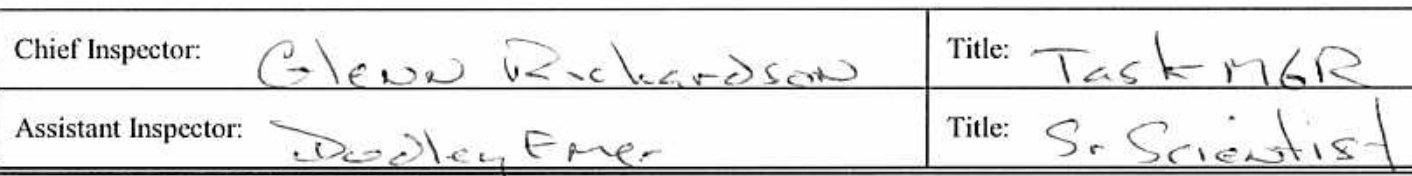

A. GENERAL INSTRUCTIONS

1. All checklist items must be completed and detailed comments made to document the results of the site inspection. The completed checklist is part of the field record of the inspection. Additional pages should be used as necessary to ensure that a complete record is made. Attach the additional pages and number all pages upon completion of the inspection.

2. Any checklist line item marked by an inspector in a SHADED BOX must be fully explained or an appropriate reference to previous reports provided. The purpose of this requirement is to provide a written explanation of inspector observations and the inspector's rationale for conclusions and recommendations. Explanations are to be placed on additional attachments and cross-referenced appropriately. Explanations, in addition to narrative, will take the form of sketches, measurements, and annotated site maps.

3. The site inspection is a walking inspection of the entire site including the perimeter and sufficient transects to be able to inspect the entire surface and all features specifically described in this checklist.

4. Field notes taken to assist in completion of this checklist will become part of the inspection record. No form is specified for field notes; however, they must be legible and in sufficient detail to enable review by succeeding inspectors and the responsible agency.

5. This unit will be inspected annually with formal reporting to the Nevada Division of Environmental Protection to be done annually. The annual letter report will include a summary with this inspection checklist attached.

B. PREPARATION (To be competed prior to site visit)

1. Has the Post-Closure Plan been reviewed?

2. Have the previous inspection reports been reviewed?

3. Were anomalies or trends detected on previous inspections?

4. Were maintenance or repairs performed since last inspection?

a. If yes, has site repair resulted in a change from as-built conditions?

b. If yes (to $4 a$ ), are revised as-built plans available that reflect repair changes?

\begin{tabular}{|l|l|l|l|}
\hline YES & NO & \multicolumn{2}{|l|}{ EXPLANATION (required if shaded box is checked) } \\
\hline & & \multicolumn{2}{|l|}{} \\
\hline & & \multicolumn{2}{|l|}{} \\
\hline & & & \multicolumn{2}{|l|}{} \\
\hline & - & & \multicolumn{2}{|l|}{} \\
\hline & & NA & \\
\hline & & NA & \\
\hline
\end{tabular}

\section{SITE INSPECTION PREPARATION}

Assemble the following, as needed, to conduct inspections:

a. Radio, pager, etc.

b. Previous letter report, inspection checklists, repair records, and as-built plans

c. Other miscellaneous support equipment

\section{SITE INSPECTION}

1. Site markers:

a. Have any posts been damaged or their anchoring weakened?

b. Are any of the use restriction signs damaged or missing?

c. Are all use restriction signs legible?

d. How many signs need to be replaced?

\begin{tabular}{|l|l|l||}
\hline YES & NO & EXPLANATION (required if shaded box is checked) \\
\hline & - & \\
\hline & - & \\
\hline & & \\
\hline 0 & \\
\hline
\end{tabular}




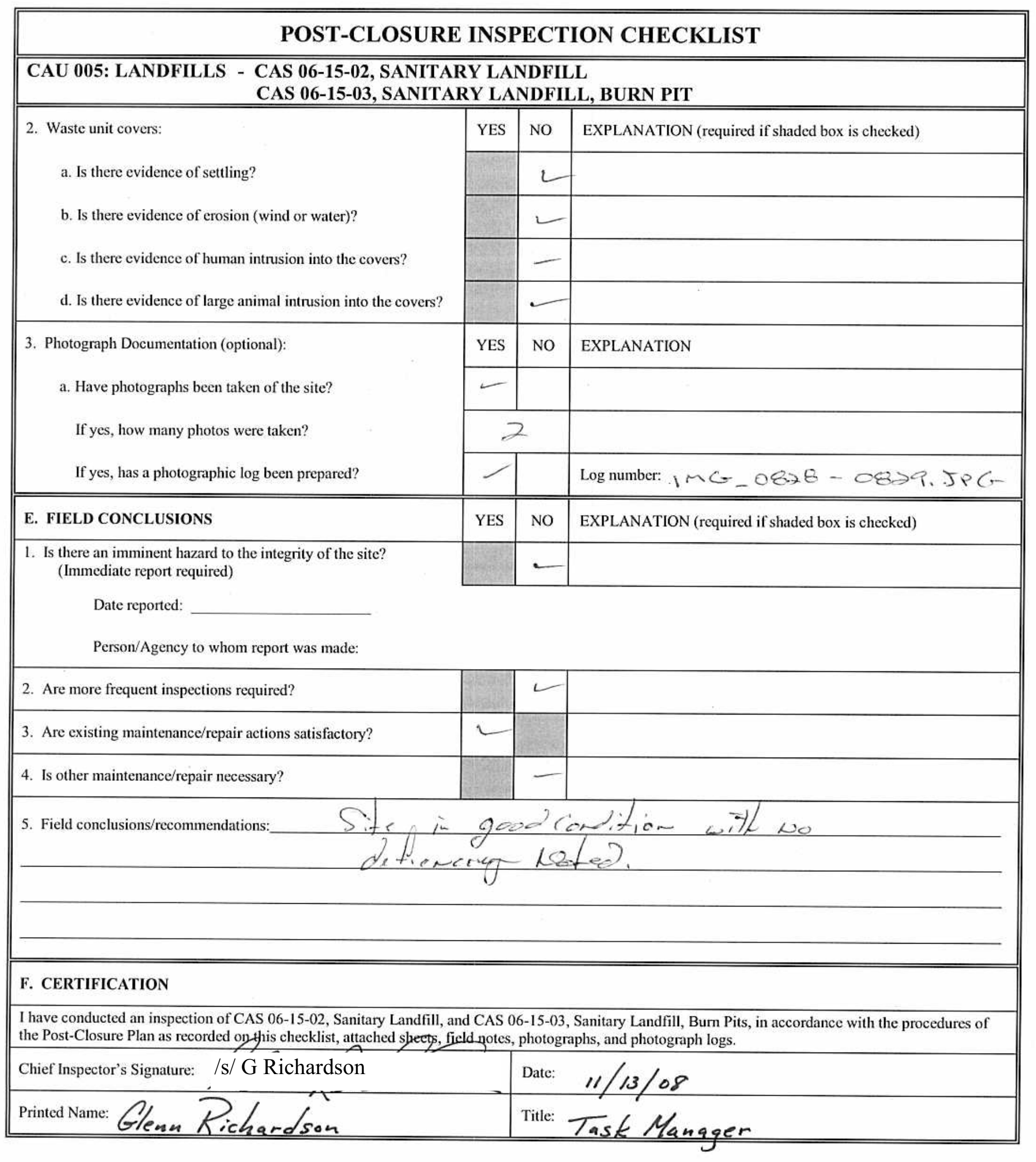




\section{POST-CLOSURE INSPECTION CHECKLIST}

\section{CAU 005: LANDFILLS - CAS 12-15-01, SANITARY LANDFILL}

\begin{tabular}{|c|c|c|c|c|}
\hline Inspection Date and Time: $\quad|>|>\rangle$ & 108 & 10,45 & Reason for Inspection: & $=1 \quad i v<\theta$ \\
\hline Date of Last Post-Closure Inspection: & $J A$ & $3, \Rightarrow 008$ & Reason for Last Post-Closure Inspection: & $A \sim \cdots \rightarrow \infty$ \\
\hline
\end{tabular}

Responsible Entity: NSTec Environmental Restoration, Nevada Test Site, Mercury, Nevada

Responsible Facility Owner: Thomas A. Thiele, Project Manager, Industrial Sites, Environmental Restoration Project

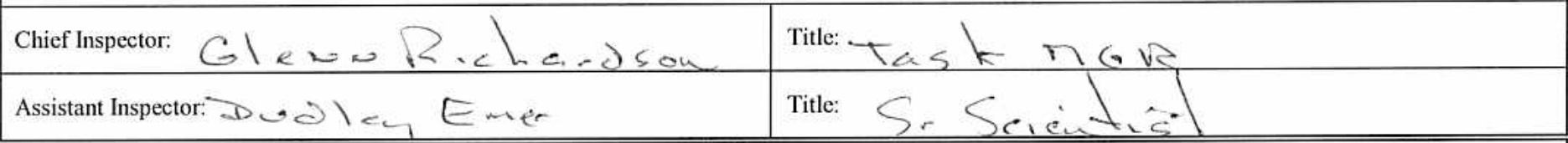

\section{A. GENERAL INSTRUCTIONS}

1. All checklist items must be completed and detailed comments made to document the results of the site inspection. The completed checklist is part of the field record of the inspection. Additional pages should be used as necessary to ensure that a complete record is made. Attach the additional pages and number all pages upon completion of the inspection.

2. Any checklist line item marked by an inspector in a SHADED BOX must be fully explained or an appropriate reference to previous reports provided. The purpose of this requirement is to provide a written explanation of inspector observations and the inspector's rationale for conclusions and recommendations. Explanations are to be placed on additional attachments and cross-referenced appropriately. Explanations, in addition to narrative, will take the form of sketches, measurements, and annotated site maps.

3. The site inspection is a walking inspection of the entire site including the perimeter and sufficient transects to be able to inspect the entire surface and all features specifically described in this checklist.

4. Field notes taken to assist in completion of this checklist will become part of the inspection record. No form is specified for field notes; however, they must be legible and in sufficient detail to enable review by succeeding inspectors and the responsible agency.

5. This unit will be inspected annually with formal reporting to the Nevada Division of Environmental Protection to be done annually. The annual letter report will include a summary with this inspection checklist attached.

\begin{tabular}{l}
\hline B. PREPARATION (To be competed prior to site visit) \\
$\begin{array}{l}\text { 1. Has the Post-Closure Plan been reviewed? } \\
\text { 2. Have the previous inspection reports been reviewed? }\end{array}$
\end{tabular}

\section{FACILITY \& UTILITY PLANS REVIEW}

The Post-Closure Plan requires the inspector to confirm that the latest copies of the relevant utility and facility plans include provisions for addressing environmental and safety issues associated with maintaining and repairing utilities and roads within this CAS. The following active utilities pass through this CAS: the main sewer line serving the Area 12 Camp the length of the CAS, overhead electrical power lines, one underground power line from the pole line to the sewer flow-meter shed, a road the length of the CAS, and the power line road.

Contact the appropriate facility and utility owners, review the appropriate plans, and complete the checklist attached on Page 2.

\section{SITE INSPECTION PREPARATION}

Assemble the following, as needed, to conduct inspections:

a. Radio, pager, etc.

b. Previous letter report, inspection checklists, repair records, and as-built plans

c. Other miscellaneous support equipment 


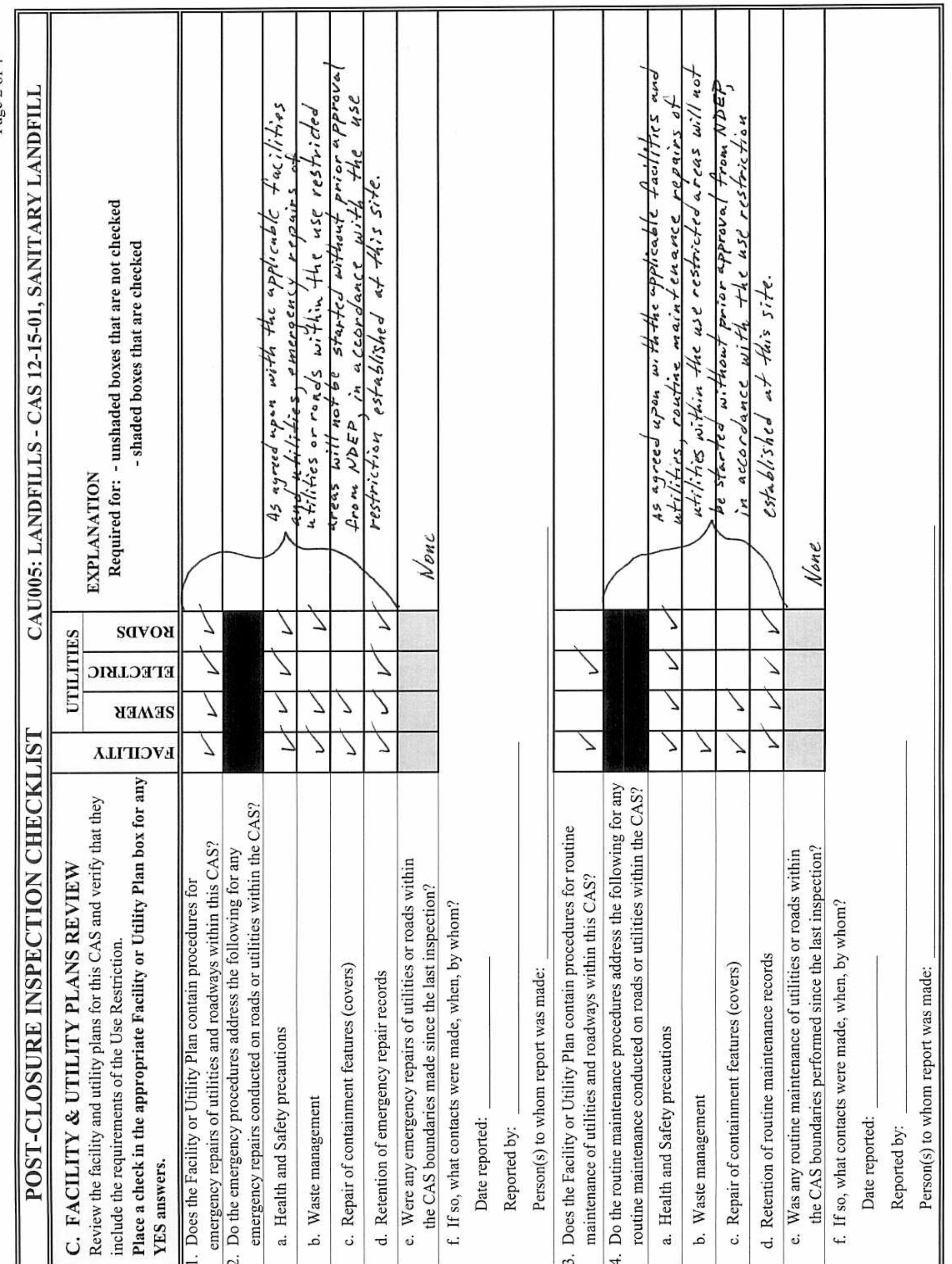


POST-CLOSURE INSPECTION CHECKLIST

\section{CAU 005: LANDFILLS - CAS 12-15-01, SANITARY LANDFILL}

\section{E. SITE INSPECTION}

1. Site markers:

a. Is there damage to the any of the 3 gates?

b. Are the gate locks in place and functional?

c. Is there damage to the fence?

d. Have any posts been damaged or their anchoring weakened?

e. Are any of the use restriction signs damaged or missing?

f. Are all use restriction signs legible?

g. How many signs need to be replaced?

2. Waste unit cover:

a. Is there evidence of settling?

b. Is there evidence of erosion (wind or water)?

c. Is there evidence of human intrusion into the cover?

d. Is there evidence of large animal intrusion into the cover?

3. Photograph Documentation (optional):

a. Have photographs been taken of the site?

If yes, how many photos were taken?

If yes, has a photographic $\log$ been prepared?

\section{E. FIELD CONCLUSIONS}

1. Is there an imminent hazard to the integrity of the site? (Immediate report required)

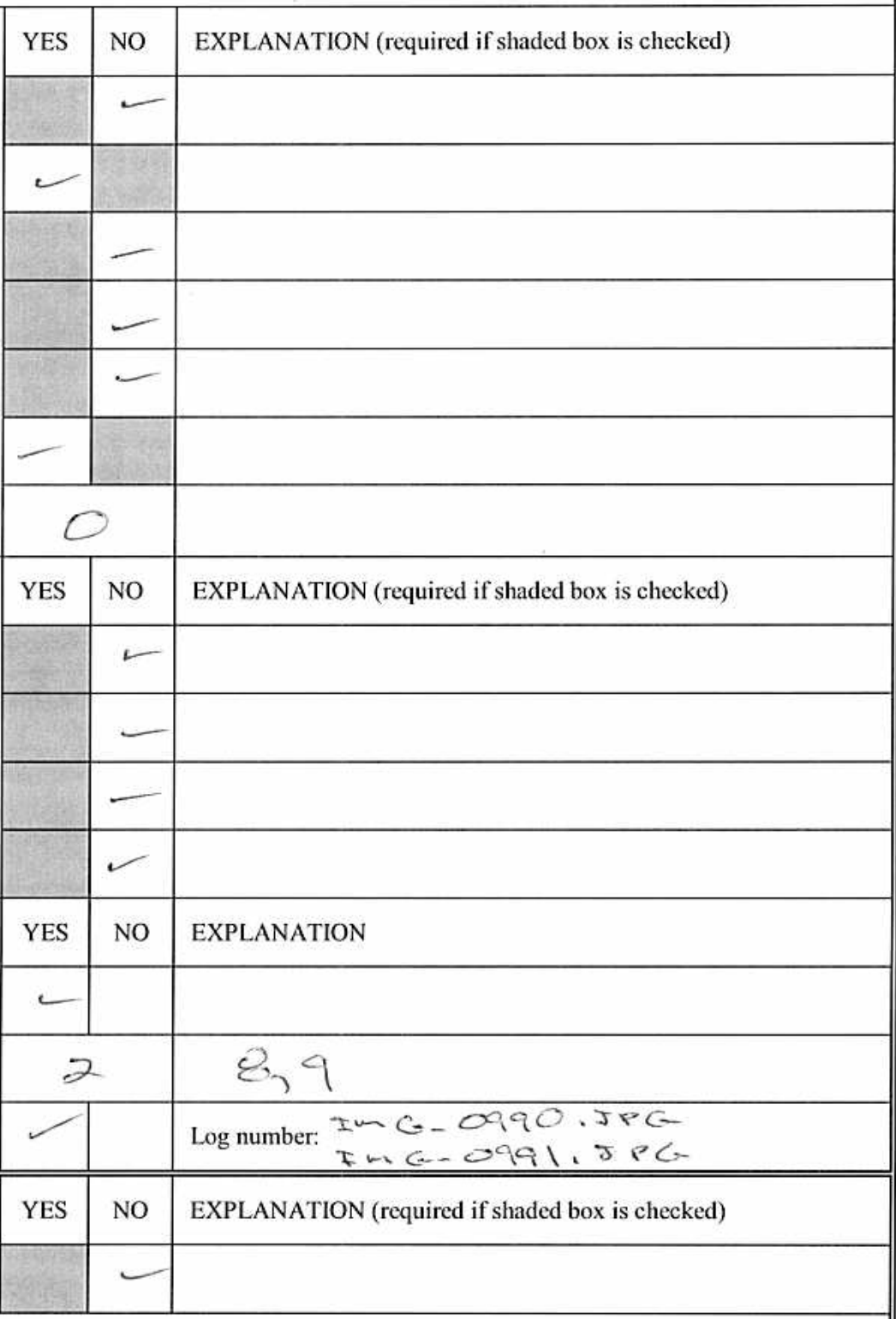

Date reported:

Person/Agency to whom report was made:

2. Are more frequent inspections required?

3. Are existing maintenance/repair actions satisfactory?

4. Is other maintenance/repair necessary?

5. Field conclusions/recommendations:

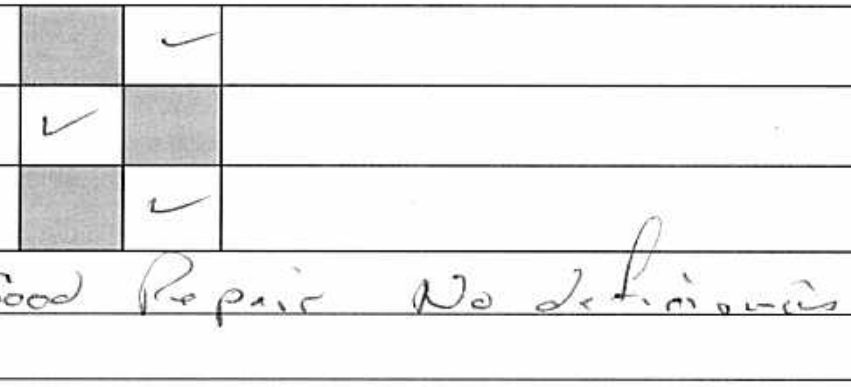




\begin{tabular}{|c|c|}
\hline \multicolumn{2}{|c|}{ POST-CLOSURE INSPECTION CHECKLIST } \\
\hline \multicolumn{2}{|c|}{ CAU 005: LANDFILLS - CAS 12-15-01, SANITARY LANDFILL } \\
\hline \multicolumn{2}{|l|}{ F. CERTIFICATION } \\
\hline \multicolumn{2}{|c|}{$\begin{array}{l}\text { I have conducted an inspection of CAS 12-15-01, Sanitary Landfill, in accordance with the procedures of the Post-Closure Plan as recorded on this checklist, } \\
\text { attached sheets, field notes, photographs, and photograph logs. }\end{array}$} \\
\hline Chief Inspector's Signature: / /s / G Richardson & Date: $\quad 10 / 27 / 08$ \\
\hline Printed Name: Glenn Richardson & Title: Task Manager \\
\hline
\end{tabular}




\section{POST-CLOSURE INSPECTION CHECKLIST}

\section{CAU 005: LANDFILLS - CAS 20-15-01, LANDFILL}

\begin{tabular}{|l|l|}
\hline \hline Inspection Date and Time: $10 / 28 / 08 \quad 12: 15 \mathrm{PM}$ & Reason for Inspection: Annual \\
\hline Date of Last Post-Closure Inspection: $12 / 11 / 07$ & Reason for Last Post-Closure Inspection: Ann nal \\
\hline
\end{tabular}

Responsible Entity: NSTec Environmental Restoration, Nevada Test Site, Mercury, Nevada

Responsible Facility Owner: Thomas A. Thiele, Project Manager, Industrial Sites, Environmental Restoration Project

\begin{tabular}{|l|l}
\hline Chief Inspector: Gleun Richardson & Title: Task Manager \\
\hline Assistant Inspector: Dudley Emer & Title: Sr. Scientist
\end{tabular}

A. GENERAL INSTRUCTIONS

1. All checklist items must be completed and detailed comments made to document the results of the site inspection. The completed checklist is part of the field record of the inspection. Additional pages should be used as necessary to ensure that a complete record is made. Attach the additional pages and number all pages upon completion of the inspection.

2. Any checklist line item marked by an inspector in a SHADED BOX must be fully explained or an appropriate reference to previous reports provided. The purpose of this requirement is to provide a written explanation of inspector observations and the inspector's rationale for conclusions and recommendations. Explanations are to be placed on additional attachments and cross-referenced appropriately. Explanations, in addition to narrative, will take the form of sketches, measurements, and annotated site maps.

3. The site inspection is a walking inspection of the entire site including the perimeter and sufficient transects to be able to inspect the entire surface and all features specifically described in this checklist.

4. Field notes taken to assist in completion of this checklist will become part of the inspection record. No form is specified for field notes; however, they must be legible and in sufficient detail to enable review by succeeding inspectors and the responsible agency.

5. This unit will be inspected annually with formal reporting to the Nevada Division of Environmental Protection to be done annually. The annual letter report will include a summary with this inspection checklist attached.

\begin{tabular}{|c|c|c|c|}
\hline B. PREPARATION (To be competed prior to site visit) & YES & NO & EXPLANATION (required if shaded box is checked) \\
\hline \multicolumn{4}{|l|}{ 1. Has the Post-Closure Plan been reviewed? } \\
\hline \multicolumn{4}{|l|}{ 2. Have the previous inspection reports been reviewed? } \\
\hline \multicolumn{4}{|l|}{ 3. Were anomalies or trends detected on previous inspections? } \\
\hline \multicolumn{4}{|l|}{ 4.Were maintenance or repairs performed since last inspection? } \\
\hline $\begin{array}{l}\text { a. If yes, has site repair resulted in a change from as-built } \\
\text { conditions? }\end{array}$ & & & NA \\
\hline $\begin{array}{l}\text { b. If yes (to } 4 \mathrm{a} \text { ), are revised as-built plans available that reflect } \\
\text { repair changes? }\end{array}$ & & & NA \\
\hline
\end{tabular}

\section{SITE INSPECTION PREPARATION}

Assemble the following, as needed, to conduct inspections:

a. Radio, pager, etc.

b. Previous letter report, inspection checklists, repair records, and as-built plans

c. Other miscellaneous support equipment

\section{SITE INSPECTION}

1. Site markers:

a. Have any posts been damaged or their anchoring weakened?

b. Are any of the use restriction signs damaged or missing?

c. Are all use restriction signs legible?

d. How many signs need to be replaced?

\begin{tabular}{|l|l|l||} 
YES & NO & EXPLANATION (required if shaded box is checked) \\
\hline & $\checkmark$ & \\
\hline & & $\begin{array}{l}\text { Approx. } 5 \text { to } 6 \text { uR signs need maintenance. Noticed } \\
2 / 3 \text { signs down and } 3 \text { signs loose. }\end{array}$ \\
\hline & & \\
\hline
\end{tabular}




\section{POST-CLOSURE INSPECTION CHECKLIST}

\section{CAU 005: LANDFILLS - CAS 20-15-01, LANDFILL}

2. Waste unit covers:

a. Is there evidence of settling?

b. Is there evidence of erosion (wind or water)?

c. Is there evidence of human intrusion into the cover?

d. Is there evidence of large animal intrusion into the cover?

3. Photograph Documentation (optional):

a. Have photographs been taken of the site?

If yes, how many photos were taken?

If yes, has a photographic log been prepared?

\section{E. FIELD CONCLUSIONS}

1. Is there an imminent hazard to the integrity of the site? (Immediate report required)

\begin{tabular}{|c|c|c|}
\hline YES & NO & EXPLANATION (required if shaded box is checked) \\
\hline & $V$ & \\
\hline & & \\
\hline & & \\
\hline & & \\
\hline YES & NO & EXPLANATION \\
\hline \multicolumn{3}{|c|}{2} \\
\hline & & Log number: IMG_1022, IMG_1023 \\
\hline YES & NO & EXPLANATION (required if shaded box is checked) \\
\hline & & \\
\hline
\end{tabular}

Date reported:

Person/Agency to whom report was made:

2. Are more frequent inspections required?

3. Are existing maintenance/repair actions satisfactory?

4. Is other maintenance/repair necessary?

5. Field conclusions/recommendations: The UR signs are not damaged and clearly legible. The T-posts are in tact, but could be readjusted to allow better stability for the uR signs. Noticed approx. 3 uR signs down that need to be rehung and approx. 3 uR signs loose that need to be tightened.

\section{F. CERTIFICATION}

I have conducted an inspection of CAS 20-15-01, Landfill, in accordance with the procedures of the Post-Closure Plan as recorded on this checklist, attached sheets, field notes, photographs, and photograph logs.

\begin{tabular}{ll|l}
\hline Chief Inspector's Signature: /s/ G Richardson & Date: $10 / 28 / 08$ \\
\hline Printed Name: Glenu Aichardson & Title: Task Manager
\end{tabular}




\section{POST-CLOSURE INSPECTION CHECKLIST}

\section{CAU 005: LANDFILLS - CAS 23-15-03, DISPOSAL SITE}

\begin{tabular}{|l|l|}
\hline \hline Inspection Date and Time: $/ 1 / 25 / 08 \quad 3: 56 \mathrm{PM}$ & Reason for Inspection: Annua/ \\
\hline Date of Last Post-Closure Inspection: $1 / 23 / 08$ & Reason for Last Post-Closure Inspection: Annua/ \\
\hline
\end{tabular}

Responsible Entity: NSTec Environmental Restoration, Nevada Test Site, Mercury, Nevada

Responsible Facility Owner: Thomas A. Thiele, Project Manager, Industrial Sites, Environmental Restoration Project

\begin{tabular}{l|l}
\hline Chief Inspector: Glenn Richardson & Title: Task Manager \\
\hline Assistant Inspector: Chris McGowin & Title: Field Technical Lead \\
\hline \hline
\end{tabular}

\section{A. GENERAL INSTRUCTIONS}

1. All checklist items must be completed and detailed comments made to document the results of the site inspection. The completed checklist is part of the field record of the inspection. Additional pages should be used as necessary to ensure that a complete record is made. Attach the additional pages and number all pages upon completion of the inspection.

2. Any checklist line item marked by an inspector in a SHADED BOX must be fully explained or an appropriate reference to previous reports provided. The purpose of this requirement is to provide a written explanation of inspector observations and the inspector's rationale for conclusions and recommendations. Explanations are to be placed on additional attachments and cross-referenced appropriately. Explanations, in addition to narrative, will take the form of sketches, measurements, and annotated site maps.

3. The site inspection is a walking inspection of the entire site including the perimeter and sufficient transects to be able to inspect the entire surface and all features specifically described in this checklist.

4. Field notes taken to assist in completion of this checklist will become part of the inspection record. No form is specified for field notes; however, they must be legible and in sufficient detail to enable review by succeeding inspectors and the responsible agency.

5. This unit will be inspected annually with formal reporting to the Nevada Division of Environmental Protection to be done annually. The annual letter report will include a summary with this inspection checklist attached.

\begin{tabular}{l}
\hline \hline B. PREPARATION (To be competed prior to site visit) \\
\hline $\begin{array}{l}\text { 1. Has the Post-Closure Plan been reviewed? } \\
\text { 2. Have the previous inspection reports been reviewed? }\end{array}$
\end{tabular}

\section{FACILITY \& UTILITY PLANS REVIEW}

The Post-Closure Plan requires the inspector to confirm that the latest copies of the relevant utility and facility plans include provisions for addressing environmental and safety issues associated with maintaining and repairing utilities and roads within this CAS. The following actively maintained utilities are within this CAS at the following active facilities: (1) The Area 23 Landfill has an access road that crosses this CAS. The road is maintained by landfill personnel. (2) The WSI training facility has a water main that services the fire hydrant for the firing range and roadways that cross the CAS.

Contact the appropriate utility owners, review the appropriate plans, and complete the checklist attached on Page 2.

\section{SITE INSPECTION PREPARATION}

Assemble the following, as needed, to conduct inspections:

a. Radio, pager, etc.

b. Previous letter report, inspection checklists, repair records, and as-built plans

c. Other miscellaneous support equipment 


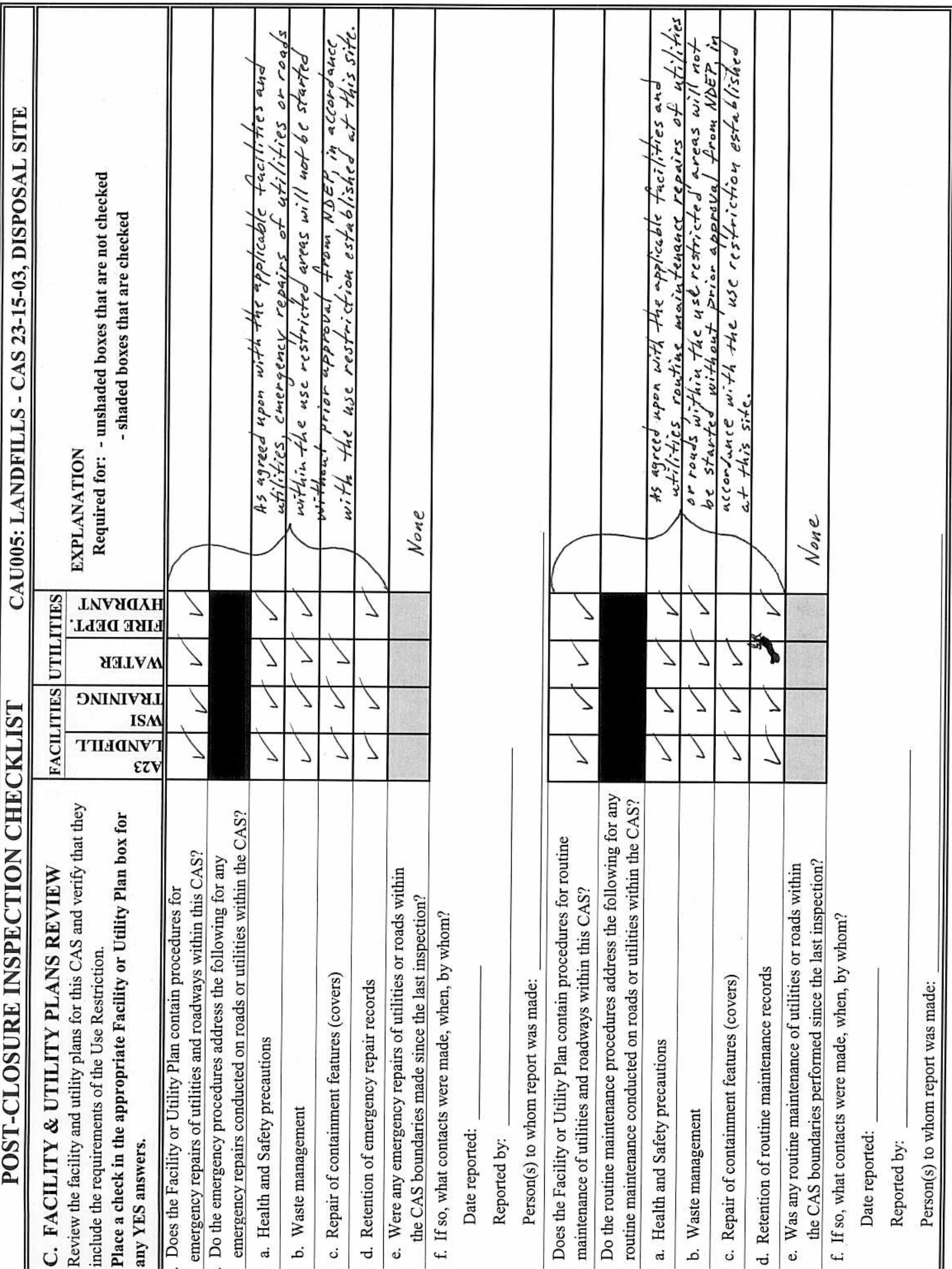


POST-CLOSURE INSPECTION CHECKLIST

\section{CAU 005: LANDFILLS - CAS 23-15-03, DISPOSAL SITE}

\section{E. SITE INSPECTION}

1. Site markers (Area 23 Landfill):

a. Have any posts been damaged or their anchoring weakened?

b. Are any of the use restriction signs damaged or missing?

c. Are all use restriction signs legible?

d. How many signs need to be replaced?

2. Waste unit cover (Area 23 Landfill):

a. Is there evidence of settling?

b. Is there evidence of erosion (wind or water)?

c. Is there evidence of human intrusion into the cover?

d. Is there evidence of large animal intrusion into the cover?

3. Site markers (WSI Training Facility):

a. Have any posts been damaged or their anchoring weakened?

b. Are any of the use restriction signs damaged or missing?

c. Are all use restriction signs legible?

d. How many signs need to be replaced?

4. Waste unit cover (WSI Training Facility):

a. Is there evidence of settling?

b. Is there evidence of erosion (wind or water)?

c. Is there evidence of human intrusion into the cover?

d. Is there evidence of large animal intrusion into the cover?

5. Photograph Documentation (optional):

a. Have photographs been taken of the site?

If yes, how many photos were taken?

If yes, has a photographic log been prepared?

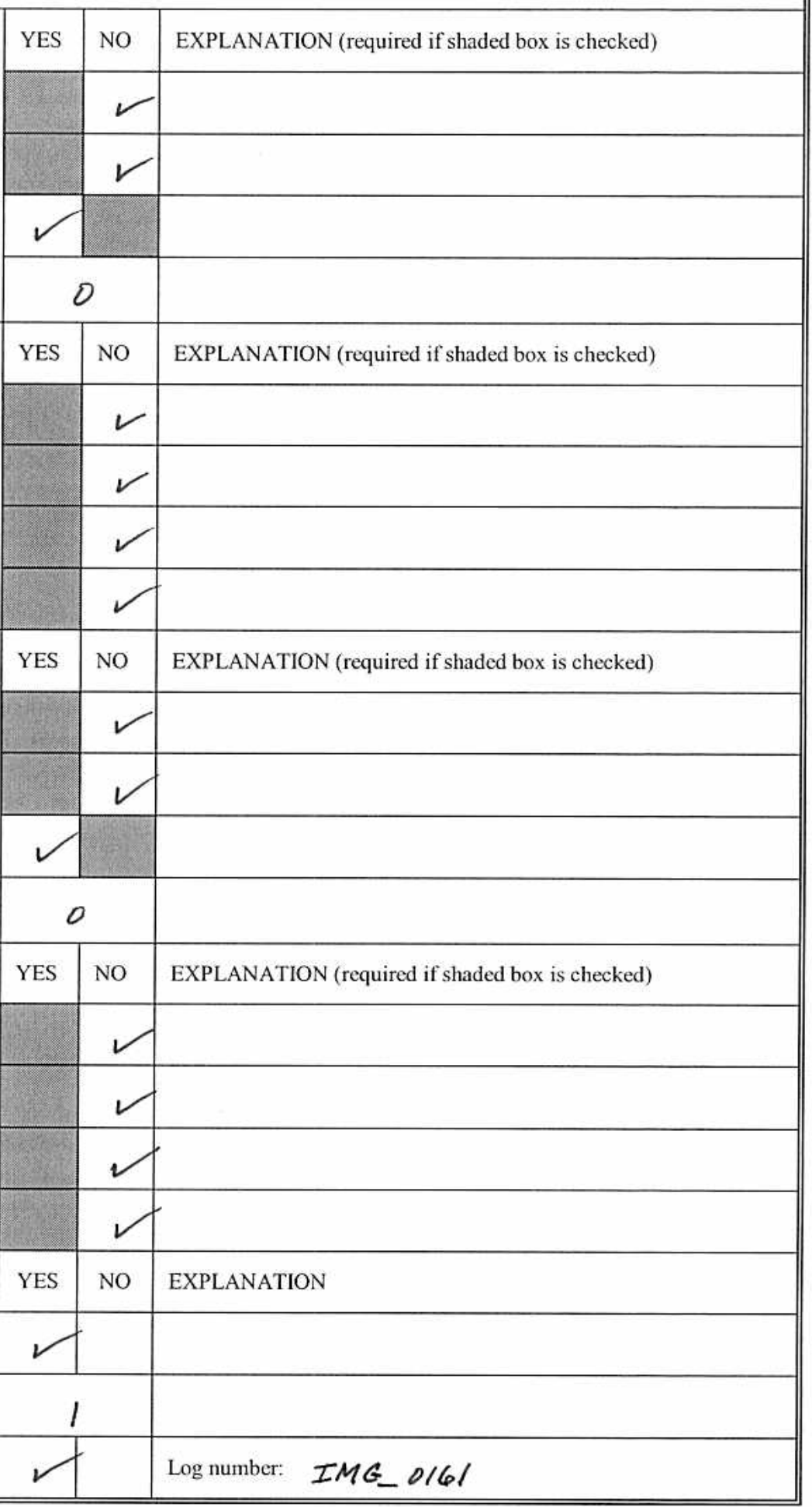




\begin{tabular}{|c|c|}
\hline \multicolumn{2}{|c|}{ POST-CLOSURE INSPECTION CHECKLIST } \\
\hline \multicolumn{2}{|c|}{ CAU 005: LANDFILLS - CAS 23-15-03, DISPOSAL SITE } \\
\hline E. FIELD CONCLUSIONS & NO $\quad$ EXPLANATION (required if shaded box is checked) \\
\hline \multicolumn{2}{|l|}{$\begin{array}{l}\text { 1. Is there an imminent hazard to the integrity of the site? } \\
\text { (Immediate report required) }\end{array}$} \\
\hline \multicolumn{2}{|l|}{ Person/Agency to whom report was made: } \\
\hline \multicolumn{2}{|l|}{ 2. Are more frequent inspections required? } \\
\hline \multicolumn{2}{|l|}{ 3. Are existing maintenance/repair actions satisfactory? } \\
\hline \multicolumn{2}{|l|}{ 4. Is other maintenance/repair necessary? } \\
\hline \multirow{2}{*}{\multicolumn{2}{|c|}{$\begin{array}{l}\text { 5. Field conclusionsirecommendations: The site is in good condition. The UR signs } \\
\text { are intact, visible, and well-maintained. There is no evidence } \\
\text { of erosion or settling on the landfill cover There are no }\end{array}$}} \\
\hline & \\
\hline \multicolumn{2}{|c|}{ issues or concerns at this site. } \\
\hline \multicolumn{2}{|l|}{ F. CERTIFICATION } \\
\hline \multicolumn{2}{|c|}{$\begin{array}{l}\text { I have conducted an inspection of CAS 23-15-03, Disposal Site, in accordance with the procedures of the Post-Closure Plan as recorded on this checklist, } \\
\text { attached sheets, field notes, photographs, and photograph logs. }\end{array}$} \\
\hline Chief Inspector's Signature: /s/ G Richardson & Date: $11 / 25 / 08$ \\
\hline Printed Name: Glenn Richardson & Title: Task Manager \\
\hline
\end{tabular}


THIS PAGE INTENTIONALLY LEFT BLANK 
CAU 113: AREA 25 R-MAD FACILITY 
THIS PAGE INTENTIONALLY LEFT BLANK 


\section{POST-CLOSURE INSPECTION CHECKLIST}

\section{CAU 113: AREA 25 R-MAD FACILITY - CAS 25-41-01, R-MAD FACILITY}

\begin{tabular}{|ll|l}
\hline \hline Inspection Date and Time: $12 / 17 / 08 \quad 12: 02 \mathrm{PM}$ & Reason for Inspection: Annual \\
\hline Date of Last Post-Closure Inspection: $\mathrm{N} / \mathrm{A}-$ Ist Inspcction & Reason for Last Post-Closure Inspection: $\mathrm{N} / \mathrm{A}$ \\
\hline
\end{tabular}

Responsible Entity: NSTec Environmental Restoration, Nevada Test Site, Mercury, Nevada

Responsible Facility Owner: Thomas A. Thiele, Project Manager, Industrial Sites, Environmental Restoration Project

\begin{tabular}{|l|l|}
\hline Chief Inspector: Glenu Richardson & Title: Task Manager \\
\hline Assistant Inspector: Dudley Emer & Title: Sr. Scientist \\
\hline \hline
\end{tabular}

A. GENERAL INSTRUCTIONS

- Complete all checklist items.

- If a SHADED BOX is checked, provide detailed information regarding what was found and/or appropriate references to other documents that have the information (e.g., Maintenance Order Form for CAU 113 dated 2/15/2008).

- All documentation must be legible and clear.

\section{B. PREPARATION (To be competed prior to site visit)}

1. Has the Post-Closure Plan been reviewed?

2. Have the previous inspection reports been reviewed?

3. Were anomalies or trends detected on previous inspections?

4. Were maintenance or repairs performed since last inspection?

5. Was the annual D\&D Engineering evaluation completed?

$$
\text { On what date? }
$$

6. Were both semi-annual D\&D radiological surveys completed?

$$
\text { On what dates? }
$$

\section{SITE INSPECTION PREPARATION}

Assemble the following, as needed, to conduct inspections:
a. Radio, pager, etc.
b. Camera, digital storage drive, and extra batteries
c. Previous Post-Closure Report, Inspection Checklists, repair records, and as-built plans
d. Tape measure
e. Key to RMAD facility
f. Other miscellaneous support equipment 


\section{POST-CLOSURE INSPECTION CHECKLIST}

\section{CAU 113: AREA 25 R-MAD FACILITY - CAS 25-41-01, R-MAD FACILITY}

\section{SITE INSPECTION}

- The site inspection is a walking inspection to check the perimeter fence and the use restriction signs. Other inspection activities are covered in accordance with the Surveillance and Maintenance Plan under the Decontamination and Decommissioning Program (copies are in the project file). The checklist should be completed during the site inspection.

- If a shaded box is checked, add detailed comments to document the results of the site inspection. Information provided should be of sufficient detail to enable reconstruction of observations regarding field conditions. Information can take the form of written narrative, sketches, measurements, and annotated site maps, all of which should be placed on additional attachments (if needed) and cross-reference appropriately. Attach the additional pages and number all pages upon completion of the inspection. The completed checklist is part of the field record of the inspection.

- Field notes taken to assist in completion of this checklist will become part of the inspection record. No form is specified for field notes, and additional field notes are not required if the checklist and associated attachments adequately describe site conditions.

1. Site markers:

a. Is there damage to the gate?

b. Is the gate lock in place and functional?

c. Is there damage to the fence?

d. Have any posts been damaged or their anchoring weakened?

e. Are any of the four (4) use restriction signs damaged or missing?

f. Are all use restriction signs legible?

g. How many use restriction signs need to be replaced?

h. Has demolition of the R-MAD building been completed?

\begin{tabular}{|c|c|c|}
\hline YES & NO & EXPLANATION (required if shaded box is checked) \\
\hline & & \\
\hline & & \\
\hline & & \\
\hline & & \\
\hline & & \\
\hline & & \\
\hline & & \\
\hline \multicolumn{3}{|c|}{0} \\
\hline & & $\begin{array}{l}\text { If "yes", the Task Manager must complete the "Follow-up Actions" } \\
\text { (not part of checklist) }\end{array}$ \\
\hline
\end{tabular}

Photograph Instructions:

- Photographs should be taken to document maintenance/repair needs at the site. These will be used to plan maintenance/repair activities and are not intended for use in the post-closure annual report.

- Anomalous features or new features (such as changes in adjacent area land use) should be photographed.

- Other photographs are optional.

- A photograph log entry will be made for each photograph taken.

2. Photograph Documentation:

a. Have photographs been taken of the site?

If yes, how many photos were taken?

If yes, has a photographic log been prepared?

\section{E. FIELD CONCLUSIONS}

1. Are more frequent inspections required?

2. Are existing maintenance/repair actions satisfactory?

3. Are maintenance/repair actions necessary?

If "yes", describe in Field conclusions/recommendations 


\section{POST-CLOSURE INSPECTION CHECKLIST}

\section{CAU 113: AREA 25 R-MAD FACILITY - CAS 25-41-01, R-MAD FACILITY}

\section{E. FIELD CONCLUSIONS (continued)}

4. Field conclusionsirecommendations: Overall site conditions are good. There are no issues as this facility transitioned from under the sém to post closure monitoring. The appropriate signage/postings are in place and well-maintained.

\section{F. CERTIFICATION}

I have conducted an inspection of CAS 25-41-01, R-MAD Facility, in accordance with the procedures of the Post-Closure Plan as recorded on this checklist, attached sheets, field notes, photographs, and photograph logs.

Chief Inspector's Signature: /s/ G Richardson

Printed Name: Glenn Kichardson

\section{Required Attachments:}

- Field Notes (if any)

- Photos (or note File Location: S:INTS\ER Share $\backslash$ Photos $\backslash$ CA4 $113 \backslash 2008 \backslash 07.02$ Date: $12 / 17 / 08$
Title: Task Manager

Distribution: Original - Industrial Sites Project Manager

Copy - Task Manager

\section{G. VERIFICATION}

I have reviewed this checklist and attachments and have verified that it is complete.

\begin{tabular}{l|l} 
Signature: $/ \mathrm{s} / \mathrm{R}$ Poderis & Date: $1-22.09$
\end{tabular}

Printed Name: Thomas A. Thiele (or designee) Reed Poderis

Distribution: Original - Task Manager 
THIS PAGE INTENTIONALLY LEFT BLANK 
CAU 115: AREA 25 TEST CELL A FACILITY 
THIS PAGE INTENTIONALLY LEFT BLANK 


\section{POST-CLOSURE INSPECTION CHECKLIST}

\section{CAU 115: AREA 25 TEST CELL A FACILITY - CAS 25-41-04, TEST CELL A FACILITY}

\begin{tabular}{|ll|l|}
\hline Inspection Date and Time: $12 / 17 / 08$ & Reason for Inspection: Annua $/$ \\
\hline Date of Last Post-Closure Inspection: $N / A \sim$ Ist Inspection $_{n}$ & Reason for Last Post-Closure Inspection: $\mathrm{N} / \mathrm{A}$ \\
\hline
\end{tabular}

Responsible Entity: NSTec Environmental Restoration, Nevada Test Site, Mercury, Nevada

Responsible Facility Owner: Thomas A. Thiele, Project Manager, Industrial Sites, Environmental Restoration Project

\begin{tabular}{l|l} 
Chief Inspector: Glenn Richardson & Title: Task Manager \\
Assistant inspector: Dudley Emer & Title: Sr. Scientist
\end{tabular}

\section{A. GENERAL INSTRUCTIONS}

- Complete all checklist items.

- If a SHADED BOX is checked, provide detailed information regarding what was found and/or appropriate references to other documents that have the information (e.g., Maintenance Order Form for CAU 115 dated 3/28/2008).

- All documentation must be legible and clear.

\section{B. PREPARATION (To be competed prior to site visit)}

1. Has the Post-Closure Plan been reviewed?

2. Have the previous inspection reports been reviewed?

3. Were anomalies or trends detected on previous inspections?

4. Were maintenance or repairs performed since last inspection?

5. Was the annual D\&D radiological survey completed?

On what date?

\begin{tabular}{|l|l|l|}
\hline YES & NO & EXPLANATION (required if shaded box is checked) \\
\hline & & \\
\hline & & $\begin{array}{c}S+M \\
\text { Engineering }\end{array}$ \\
\hline & & \\
\hline & \\
\hline
\end{tabular}

\section{SITE INSPECTION PREPARATION}

Assemble the following, as needed, to conduct inspections:
a. Radio, pager, etc.
b. Camera, digital storage drive, and extra batteries
c. Previous Post-Closure Report, Inspection Checklists, repair records, and as-built plans
d. Tape measure
e. ER66 key to Test Cell A facility
f. Other miscellaneous support equipment

\section{SITE INSPECTION}

- The site inspection is a walking inspection of the fence perimeter (of the Test Cell A compound) and of the perimeter of the userestricted (pad) area. The checklist should be completed during the site inspection.

- If a shaded box is checked, add detailed comments to document the results of the site inspection. Information provided should be of sufficient detail to enable reconstruction of observations regarding field conditions. Information can take the form of written narrative, sketches, measurements, and annotated site maps, all of which should be placed on additional attachments (if needed) and cross-reference appropriately. Attach the additional pages and number all pages upon completion of the inspection. The completed checklist is part of the field record of the inspection.

- Field notes taken to assist in completion of this checklist will become part of the inspection record. No form is specified for field notes, and additional field notes are not required if the checklist and associated attachments adequately describe site conditions. 


\section{POST-CLOSURE INSPECTION CHECKLIST}

\section{CAU 115: AREA 25 TEST CELL A FACILITY - CAS 25-41-04, TEST CELL A FACILITY}

\section{SITE INSPECTION}

1. Site markers:

a. Is there damage to the gate?

b. Is the gate lock in place and functional?

c. Is there damage to the fence?

d. Have any posts been damaged or their anchoring weakened?

e. Are any of the five (5) use restriction signs damaged or missing?

f. Are all use restriction signs legible?

g. How many signs need to be replaced?

h. Are any of the four (4) Underground Radiological Material signs (for pad) damaged or missing?

i. Are all of the Underground Radiological Material signs legible?

j. How many Underground Radiological Material signs need to be replaced?

\begin{tabular}{|l|l|l|}
\hline YES & NO & EXPLANATION (required if shaded box is checked) \\
\hline & & \\
\hline & & \\
\hline & & \\
\hline & & \\
\hline & & \\
\hline & & \\
\hline & & \\
\hline & & \\
\hline
\end{tabular}

Photograph Instructions:

- Photographs should be taken to document maintenance/repair needs at the site. These will be used to plan maintenance/repair activities and are not intended for use in the post-closure annual report.

- Anomalous features or new features (such as changes in adjacent area land use) should be photographed.

- Other photographs are optional.

- A photograph log entry will be made for each photograph taken.

2. Photograph Documentation:

a. Have photographs been taken of the site?

If yes, how many photos were taken?

If yes, has a photographic log been prepared?

\begin{tabular}{|l|l|l|}
\hline YES & NO & EXPLANATION \\
\hline & & \\
\hline YES & NO & EXPLANATION (required if shaded box is checked) \\
\hline & $\checkmark$ & $\begin{array}{l}\text { The configuration of the radiological posted } \\
\text { areas needs to be modified. }\end{array}$ \\
\hline & & \begin{tabular}{l} 
If "yes", describe below \\
\hline
\end{tabular}
\end{tabular}

\section{E. FIELD CONCLUSIONS}

1. Are more frequent inspections required?

2. Are existing maintenance/repair actions satisfactory?

3. Are maintenance/repair actions necessary?

4. Field conclusions/recommendations: The external chain-linkfencing is well maintained and very secure. Noticed $3 \& R$ signs down around the concrete pad and, UR sign was missing. All URMA signs/postings were in good condition, but the configuration of the radiological posted areas will be modified to improve awareness or radiological site 


\section{POST-CLOSURE INSPECTION CHECKLIST}

\section{CAU 115: AREA 25 TEST CELL A FACILITY - CAS 25-41-04, TEST CELL A FACILITY}

\section{F. CERTIFICATION}

I have conducted an inspection of CAS 25-41-04, Test Cell A Facility, in accordance with the procedures of the Post-Closure Plan as recorded on this checklist, attached sheets, field notes, photographs, and photograph logs.

\begin{tabular}{l|l} 
Chief Inspector's Signature: /s/G Richardson & Date: $12 / 17 / 08$ \\
\hline Printed Name: Glenn Richardson & Title: Task Manager
\end{tabular}

Required Attachments:

- Field Notes (if any)

- Photos (or note File Location: S:INTSIER Share Photos $\backslash$ CAU 115 $2008 \backslash 12-17.08(4525-41-84)$

Distribution: Original - Industrial Sites Project Manager

Copy - Task Manager

\section{G. VERIFICATION}

I have reviewed this checklist and attachments and have verified that it is complete.

\begin{tabular}{l|l}
\hline Signature: $/ \mathrm{s} / \mathrm{R}$ Poderis & Date: $1-22-09$
\end{tabular}

Printed Name: Thomas A. Thiele (or designee) Peed Poderis

Distribution: Original - Task Manager 
THIS PAGE INTENTIONALLY LEFT BLANK 
CAU 118: AREA 27 SUPER KUKLA FACILITY 
THIS PAGE INTENTIONALLY LEFT BLANK 


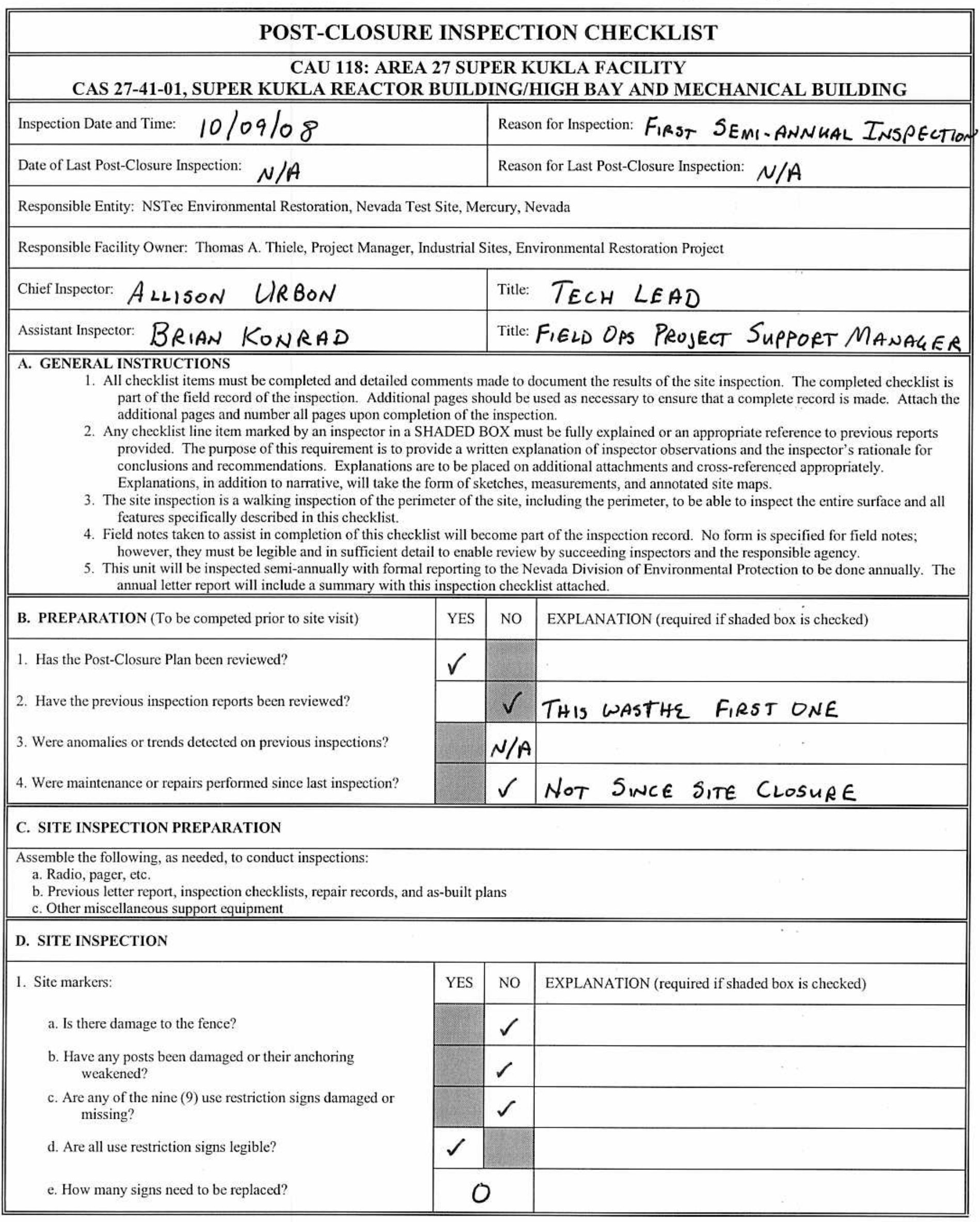




\section{POST-CLOSURE INSPECTION CHECKLIST}

\section{CAU 118: AREA 27 SUPER KUKLA FACILITY}

CAS 27-41-01, SUPER KUKLA REACTOR BUILDING/HIGH BAY AND MECHANICAL BUILDING

2. Use-restricted area:

a. Is there evidence of human intrusion onto the site?

3. Photograph Documentation (optional):

a. Have photographs been taken of the site?

If yes, how many photos were taken?

If yes, has a photographic log been prepared?

\section{E. FIELD CONCLUSIONS}

1. Are more frequent inspections required?

2. Are existing maintenance/repair actions satisfactory?

3. Is other maintenance/repair necessary?

\section{\begin{tabular}{|c|c|l} 
YES & NO & EXPLANATION (required if shaded box is checked)
\end{tabular}}

4. Field conclusions/recommendations: FENCE AND SIGNS IN GDOD CONDITION. NO

EVIDENCE OF HUMAN INTRUSION ON THE SITE.

\section{F. CERTIFICATION}

I have conducted an inspection of CAS 27-41-01, Super Kukla Reactor Building/High Bay and Mechanical Building, in accordance with the procedures of the Post-Closure Plan as recorded on this checklist, attached sheets, field notes, photographs, and photograph logs.

\begin{tabular}{l|l}
\hline Chief Inspector's Signature: /s/ A Urbon & Date: $10 / 9 / 08$ \\
\hline Printed Name: ALLISON URBON & Title: TECH LEAD
\end{tabular}




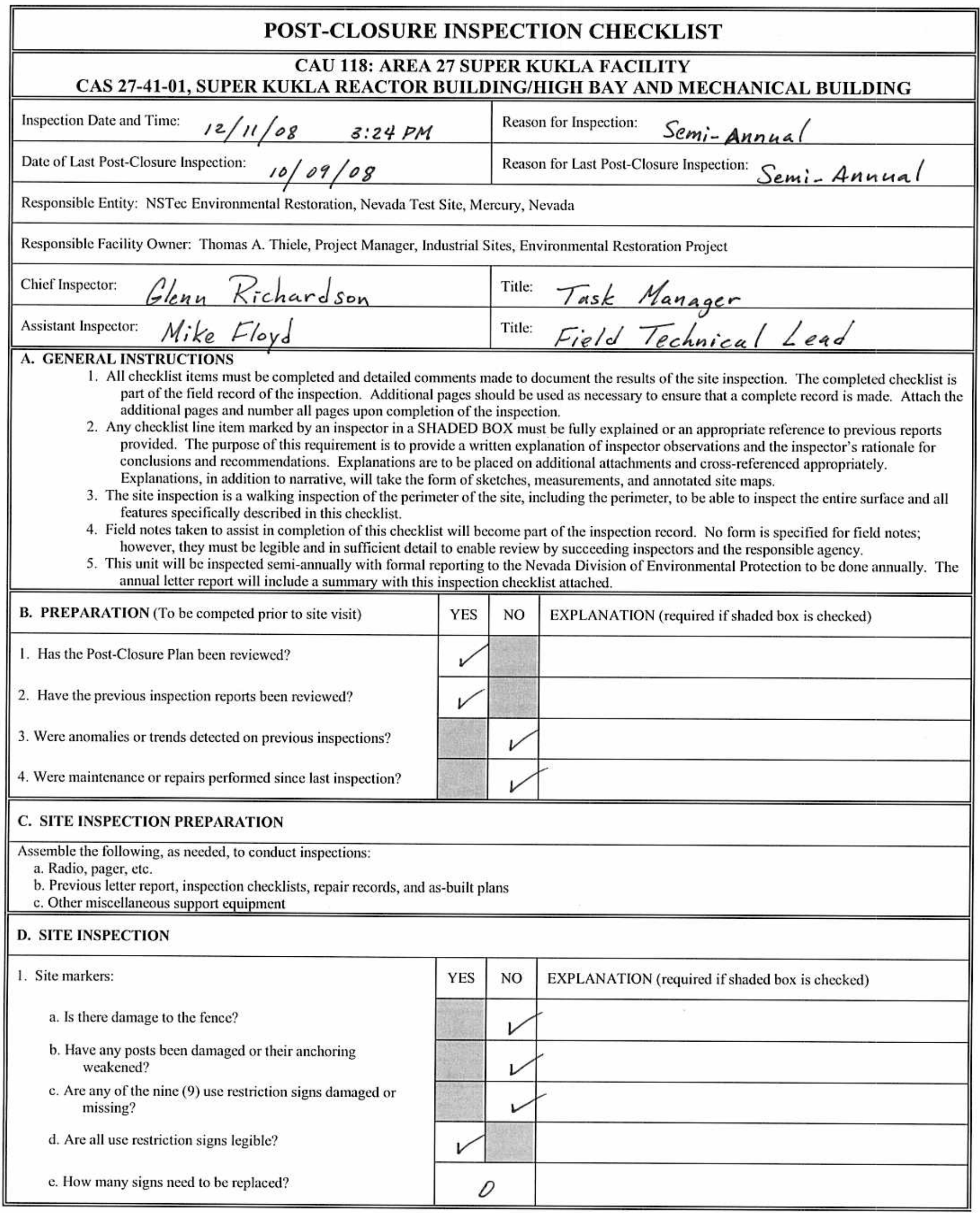




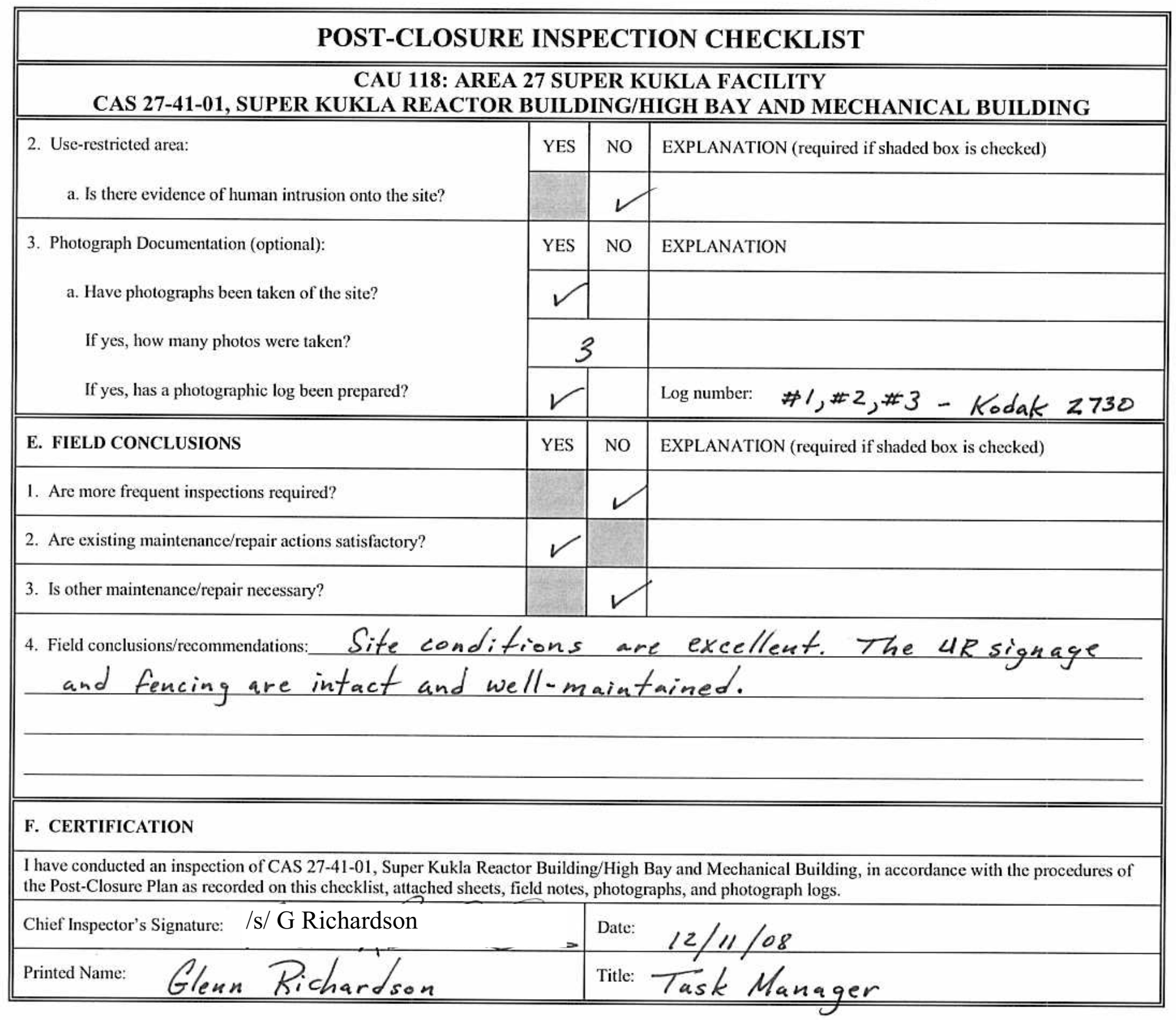


CAU 127: AREAS 25 AND 26 STORAGE TANKS 
THIS PAGE INTENTIONALLY LEFT BLANK 


\section{POST-CLOSURE INSPECTION CHECKLIST}

\section{CAU 127: AREAS 25 AND 26 STORAGE TANKS - CAS 25-01-07, ABOVEGROUND STORAGE TANK}

\begin{tabular}{|c|c|c|c|}
\hline Inspection Date and Time: $12 / 8 / 08$ & $2: 5>p M$ & 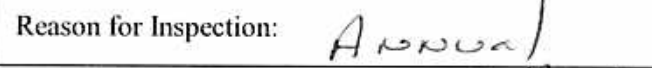 & \\
\hline Date of Last Post-Closure Inspection: & $\left.\operatorname{lA}\right|^{\mathrm{st}} \mathrm{in}$ & Reason for Last Post-Closure Inspection: ${ }^{\mathrm{N}}$, st , & ins pero. \\
\hline
\end{tabular}

Responsible Entity: NSTec Environmental Restoration, Nevada Test Site, Mercury, Nevada

Responsible Facility Owner: Thomas A. Thiele, Project Manager, Industrial Sites, Environmental Restoration Project

\begin{tabular}{|c|c|}
\hline 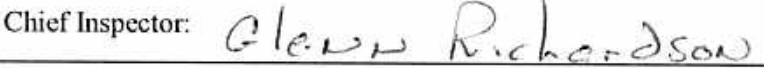 & Title: T, As K Mxa jer \\
\hline Assistant Inspector: $D_{C}, l_{y}$ & Title: \\
\hline
\end{tabular}

A. GENERAL INSTRUCTIONS

1. All checklist items must be completed and detailed comments made to document the results of the site inspection. The completed checklist is part of the field record of the inspection. Additional pages should be used as necessary to ensure that a complete record is made. Attach the additional pages and number all pages upon completion of the inspection.

2. Any checklist line item marked by an inspector in a SHADED BOX must be fully explained or an appropriate reference to previous reports provided. The purpose of this requirement is to provide a written explanation of inspector observations and the inspector's rationale for conclusions and recommendations. Explanations are to be placed on additional attachments and cross-referenced appropriately. Explanations, in addition to narrative, will take the form of sketches, measurements, and annotated site maps.

3. The site inspection is a walking inspection of the entire site including the perimeter and sufficient transects to be able to inspect the entire surface and all features specifically described in this checklist.

4. Field notes taken to assist in completion of this checklist will become part of the inspection record. No form is specified for field notes; however, they must be legible and in sufficient detail to enable review by succeeding inspectors and the responsible agency.

5. This unit will be inspected annually with formal reporting to the Nevada Division of Environmental Protection to be done annually. The annual letter report will include a summary with this inspection checklist attached.

B. PREPARATION (To be competed prior to site visit)

1. Has the Post-Closure Plan been reviewed?

2. Have the previous inspection reports been reviewed?

3. Were anomalies or trends detected on previous inspections?

4. Were maintenance or repairs performed since last inspection?

\begin{tabular}{|l|l|l||}
\hline YES & NO & EXPLANATION (required if shaded box is checked) \\
\hline & & \\
\hline & & $\ldots$ \\
\hline & & $\ldots$ \\
\hline
\end{tabular}

\section{SITE INSPECTION PREPARATION}

Assemble the following, as needed, to conduct inspections:

a. Radio, pager, etc.

b. Previous letter report, inspection checklists, repair records, and as-built plans

c. Other miscellaneous support equipment

\section{SITE INSPECTION}

1. Site markers:

a. Have any posts been damaged or their anchoring weakened?

b. Are any of the four use restriction signs damaged or missing?

c. Are all use restriction signs legible?

d. How many signs need to be replaced?

2. Use-restricted area:

a. Is there evidence of human intrusion onto the site?

\begin{tabular}{|l|l|l|}
\hline YES & NO & EXPLANATION (required if shaded box is checked) \\
\hline & & \\
\hline & & \\
\hline & & \\
\hline YES & NO & EXPLANATION (required if shaded box is checked) \\
\hline & & \\
\hline
\end{tabular}




\begin{tabular}{|c|c|c|c|}
\hline \multicolumn{4}{|c|}{ POST-CLOSURE INSPECTION CHECKLIST } \\
\hline \multicolumn{2}{|c|}{ CAU 127: AREAS 25 AND 26 STORAGE TANKS } & \multicolumn{2}{|r|}{ CAS 25-01-07, ABOVEGROUND STORAGE TANK } \\
\hline \multirow{2}{*}{$\begin{array}{l}\text { 3. Photograph Documentation (optional): } \\
\text { a. Have photographs been taken of the site? }\end{array}$} & YES & NO & EXPLANATION \\
\hline & $\sim$ & & \\
\hline If yes, how many photos were taken? & \multicolumn{2}{|c|}{1} & \\
\hline If yes, has a photographic log been prepared? & $\sim$ & & 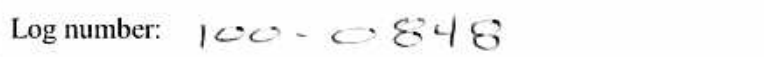 \\
\hline E. FIELD CONCLUSIONS & YES & NO & EXPLANATION (required if shaded box is checked) \\
\hline \multicolumn{2}{|l|}{ 1. Are more frequent inspections required? } & & \\
\hline \multicolumn{2}{|l|}{ 2. Are existing maintenance/repair actions satisfactory? } & & \\
\hline 3. Is other maintenance/repair necessary? & & & \\
\hline \multirow{2}{*}{\multicolumn{4}{|c|}{ 4. Field conclusions/recommendations: }} \\
\hline & & & \\
\hline \multicolumn{4}{|l|}{ F. CERTIFICATION } \\
\hline \multicolumn{4}{|c|}{$\begin{array}{l}\text { I have conducted an inspection of CAS } 25-01-07 \text {, Aboveground Storage Tank, in accordance with the procedures of the Post-Closure Plan as recorded on } \\
\text { this checklist, attached sheets, field notes, photographs, and photograph logs. }\end{array}$} \\
\hline \multicolumn{2}{|c|}{ Chief Inspector's Signature: $/ \mathrm{s} / \mathrm{G}$ Richardson } & Date: & \\
\hline Printed Name: Glenn Richardson & & Title: & lanager \\
\hline
\end{tabular}




\section{POST-CLOSURE INSPECTION CHECKLIST}

CAU 127: AREAS 25 AND 26 STORAGE TANKS - CAS 25-02-02, UNDERGROUND STORAGE TANK

\begin{tabular}{|c|c|c|c|c|}
\hline Inspection Date and Time: $1,2 / 0, \pi /$ & (बह & $2: 57 p m$ & Reason for Inspection: Afo, 200 & \\
\hline Date of Last Post-Closure Inspection: & $x / A$ & ist wespecticio & Reason for Last Post-Closure Inspection: & $\omega / A$ \\
\hline
\end{tabular}

Responsible Entity: NSTec Environmental Restoration, Nevada Test Site, Mercury, Nevada

Responsible Facility Owner: Thomas A. Thiele, Project Manager, Industrial Sites, Environmental Restoration Project

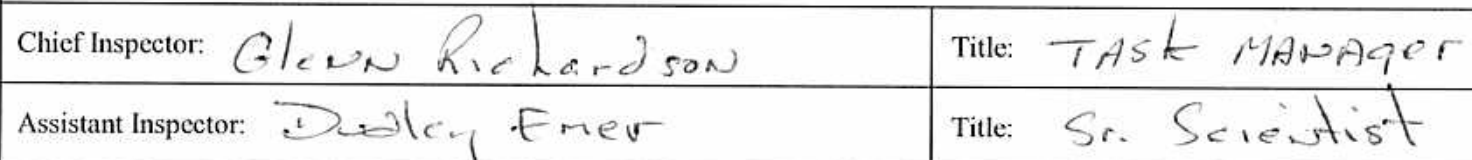

A. GENERAL INSTRUCTIONS

1. All checklist items must be completed and detailed comments made to document the results of the site inspection. The completed checklist is part of the field record of the inspection. Additional pages should be used as necessary to ensure that a complete record is made. Attach the additional pages and number all pages upon completion of the inspection.

2. Any checklist line item marked by an inspector in a SHADED BOX must be fully explained or an appropriate reference to previous reports provided. The purpose of this requirement is to provide a written explanation of inspector observations and the inspector's rationale for conclusions and recommendations. Explanations are to be placed on additional attachments and cross-referenced appropriately. Explanations, in addition to narrative, will take the form of sketches, measurements, and annotated site maps.

3. The site inspection is a walking inspection of the entire site including the perimeter and sufficient transects to be able to inspect the entire surface and all features specifically described in this checklist.

4. Field notes taken to assist in completion of this checklist will become part of the inspection record. No form is specified for field notes; however, they must be legible and in sufficient detail to enable review by succeeding inspectors and the responsible agency.

5. This unit will be inspected annually with formal reporting to the Nevada Division of Environmental Protection to be done annually. The annual letter report will include a summary with this inspection checklist attached.

B. PREPARATION (To be competed prior to site visit)

1. Has the Post-Closure Plan been reviewed?

2. Have the previous inspection reports been reviewed?

3. Were anomalies or trends detected on previous inspections?

4. Were maintenance or repairs performed since last inspection?

\begin{tabular}{|l|l|l|}
\hline YES & NO & EXPLANATION (required if shaded box is checked) \\
\hline & & \\
\hline & & $N / A, S^{-1}$ inspec \\
\hline & & $N / A$ \\
\hline
\end{tabular}

\section{SITE INSPECTION PREPARATION}

Assemble the following, as needed, to conduct inspections:

a. Radio, pager, etc.

b. Previous letter report, inspection checklists, repair records, and as-built plans

c. Other miscellaneous support equipment

\section{SITE INSPECTION}

1. Site markers:

a. Have any posts been damaged or their anchoring weakened?

b. Are any of the four use restriction signs damaged or missing?

c. Are all use restriction signs legible?

d. How many use restriction signs need to be replaced?

e. Are any of the four URMA signs damaged or missing?

f. Are all URMA signs legible?

\begin{tabular}{|l|l|l||}
\hline YES & NO & EXPLANATION (required if shaded box is checked) \\
\hline & - & \\
\hline & - & \\
\hline & & \\
\hline \multicolumn{2}{|c|}{} & \\
\hline & & \\
\hline & & \\
\hline
\end{tabular}




\section{POST-CLOSURE INSPECTION CHECKLIST}

\section{CAU 127: AREAS 25 AND 26 STORAGE TANKS - CAS 25-02-02, UNDERGROUND STORAGE TANK}

\begin{tabular}{|c|c|c|c|}
\hline \multirow{2}{*}{$\begin{array}{l}\text { 1. Site markers (continued): } \\
\text { g. How many URMA signs need to be replaced? }\end{array}$} & YES & NO & EXPLANATION (required if shaded box is checked) \\
\hline & \multicolumn{2}{|c|}{0} & \\
\hline \multirow{2}{*}{$\begin{array}{l}\text { 2. Use-restricted area: } \\
\text { a. Is there evidence of human intrusion onto the site? }\end{array}$} & YES & NO & EXPLANATION (required if shaded box is checked) \\
\hline & & 2 & \\
\hline \multirow[t]{2}{*}{ 3. Photograph Documentation (optional): } & YES & NO & EXPLANATION \\
\hline & 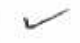 & & \\
\hline If yes, how many photos were taken? & \multicolumn{2}{|c|}{2} & \\
\hline If yes, has a photographic log been prepared? & $\sim$ & & $\begin{aligned} & \text { Log number: } \operatorname{lm} 6-100-855 \\
& \operatorname{lm}_{0}-100-856 \\
&\end{aligned}$ \\
\hline E. FIELD CONCLUSIONS & YES & NO & EXPLANATION (required if shaded box is checked) \\
\hline \multicolumn{4}{|l|}{ 1. Are more frequent inspections required? } \\
\hline 2. Are existing maintenance/repair actions satisfactory? & & & $\omega / A$ \\
\hline 3. Is other maintenance/repair necessary? & & 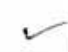 & \\
\hline 4. Field conclusions/recommendations: & & & OL \\
\hline
\end{tabular}

\section{F. CERTIFICATION}

I have conducted an inspection of CAS 25-02-02, Underground Storage Tank, in accordance with the procedures of the Post-Closure Plan as recorded on this checklist, attached sheets, field notes, photographs, and photograph logs.

\begin{tabular}{l|l|l}
\hline Chief Inspector's Signature: /s/ G Richardson & Date: $12 / 09 / 08$ \\
\hline Printed Name: Glenn Richardson & Title: Task Manager
\end{tabular}


CAU 137: WASTE DISPOSAL SITES 
THIS PAGE INTENTIONALLY LEFT BLANK 


\section{POST-CLOSURE INSPECTION CHECKLIST}

\section{CAU 137: WASTE DISPOSAL SITES - CAS 01-08-01, WASTE DISPOSAL SITE}

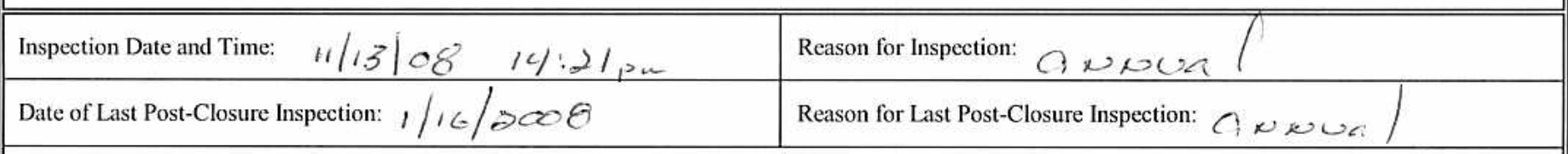

Responsible Entity: NSTec Environmental Restoration, Nevada Test Site, Mercury, Nevada

Responsible Facility Owner: Thomas A. Thiele, Project Manager, Industrial Sites, Environmental Restoration Project

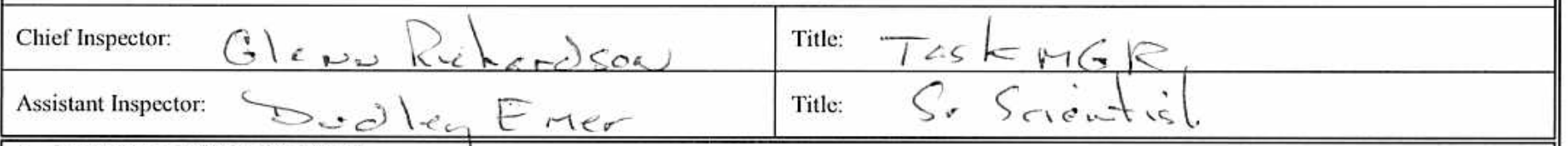

A. GENERAL INSTRUCTIONS

1. All checklist items must be completed and detailed comments made to document the results of the site inspection. The completed checklist is part of the field record of the inspection. Additional pages should be used as necessary to ensure that a complete record is made. Attach the additional pages and number all pages upon completion of the inspection.

2. Any checklist line item marked by an inspector in a SHADED BOX must be fully explained or an appropriate reference to previous reports provided. The purpose of this requirement is to provide a written explanation of inspector observations and the inspector's rationale for conclusions and recommendations. Explanations are to be placed on additional attachments and cross-referenced appropriately. Explanations, in addition to narrative, will take the form of sketches, measurements, and annotated site maps.

3. The site inspection is a walking inspection of the entire site including the perimeter and sufficient transects to be able to inspect the entire surface and all features specifically described in this checklist.

4. Field notes taken to assist in completion of this checklist will become part of the inspection record. No form is specified for field notes; however, they must be legible and in sufficient detail to enable review by succeeding inspectors and the responsible agency.

5. This unit will be inspected annually with formal reporting to the Nevada Division of Environmental Protection to be done annually. The annual letter report will include a summary with this inspection checklist attached.

\begin{tabular}{|l|l|l|l||}
\hline \hline B. PREPARATION (To be competed prior to site visit) & YES & NO & EXPLANATION (required if shaded box is checked) \\
\hline 1. Has the Post-Closure Plan been reviewed? & & & \\
2. Have the previous inspection reports been reviewed? & & & \\
3. Were anomalies or trends detected on previous inspections? & & & \\
\cline { 2 - 5 } 4. Were maintenance or repairs performed since last inspection? & & & \\
\hline \hline
\end{tabular}

\section{SITE INSPECTION PREPARATION}

Assemble the following, as needed, to conduct inspections:

a. Radio, pager, etc.

b. Previous letter report, inspection checklists, repair records, and as-built plans

c. Other miscellaneous support equipment

\section{SITE INSPECTION}

1. Site markers:

a. Is there damage to the fence?

b. Have any posts been damaged or their anchoring weakened?

c. Are any of the 10 use restriction signs damaged or missing?

d. Are all use restriction signs legible?

e. How many signs need to be replaced?

\begin{tabular}{|c|c|l||}
\hline YES & NO & EXPLANATION (required if shaded box is checked) \\
\hline & - & \\
\hline & - & \\
\hline & $\gamma$ & \\
\hline- & & \\
\hline
\end{tabular}




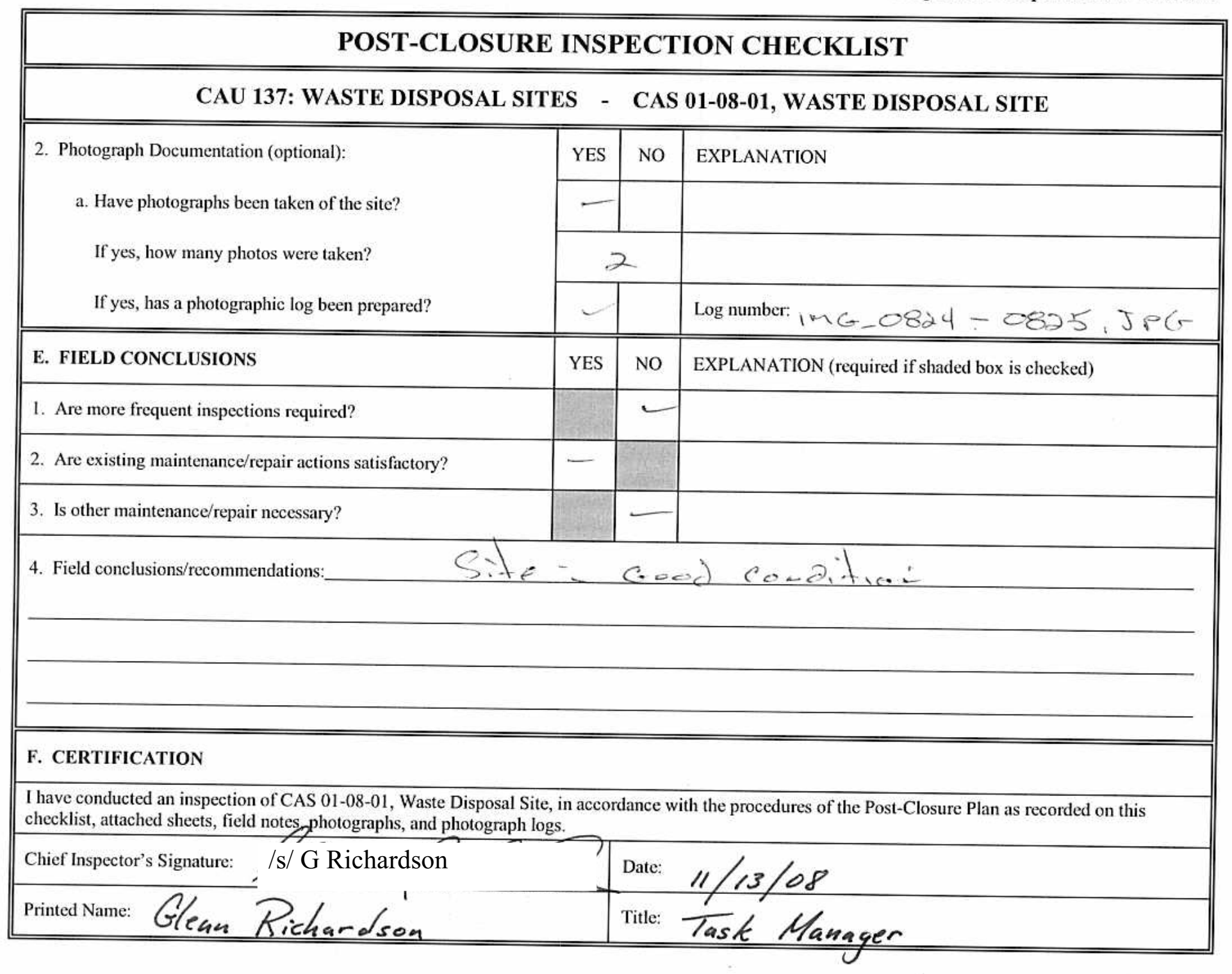




\section{POST-CLOSURE INSPECTION CHECKLIST}

\section{CAU 137: WASTE DISPOSAL SITES - CAS 07-23-02, RADIOACTIVE WASTE DISPOSAL SITE}

\begin{tabular}{|c|c|}
\hline Inspection Date and Time: $11 / 4 / \mathrm{C}, \quad 11:>4 A M$ & Reason for Inspection: \\
\hline Date of Last Post-Closure Inspection: $1 / 16 / 2008$ & Reason for Last Post-Closure Inspection: \\
\hline
\end{tabular}

Responsible Entity: NSTec Environmental Restoration, Nevada Test Site, Mercury, Nevada

Responsible Facility Owner: Thomas A. Thiele, Project Manager, Industrial Sites, Environmental Restoration Project

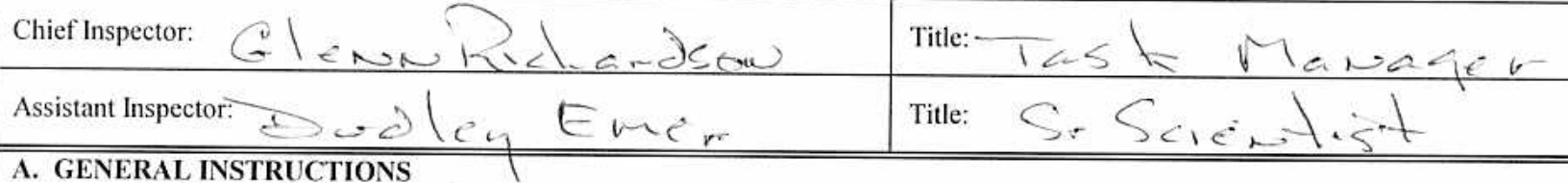

1. All checklist items must be completed and detailed comments made to document the results of the site inspection. The completed checklist is part of the field record of the inspection. Additional pages should be used as necessary to ensure that a complete record is made. Attach the additional pages and number all pages upon completion of the inspection.

2. Any checklist line item marked by an inspector in a SHADED BOX must be fully explained or an appropriate reference to previous reports provided. The purpose of this requirement is to provide a written explanation of inspector observations and the inspector's rationale for conclusions and recommendations. Explanations are to be placed on additional attachments and cross-referenced appropriately. Explanations, in addition to narrative, will take the form of sketches, measurements, and annotated site maps.

3. The site inspection is a walking inspection of the entire site including the perimeter and sufficient transects to be able to inspect the entire surface and all features specifically described in this checklist.

4. Field notes taken to assist in completion of this checklist will become part of the inspection record. No form is specified for field notes; however, they must be legible and in sufficient detail to enable review by succeeding inspectors and the responsible agency.

5. This unit will be inspected annually with formal reporting to the Nevada Division of Environmental Protection to be done annually. The annual letter report will include a summary with this inspection checklist attached.

B. PREPARATION (To be competed prior to site visit)

1. Has the Post-Closure Plan been reviewed?

2. Have the previous inspection reports been reviewed?

3. Were anomalies or trends detected on previous inspections?

4. Were maintenance or repairs performed since last inspection?

\begin{tabular}{|l|l|l|} 
YES & NO & EXPLANATION (required if shaded box is checked) \\
\hline & & \\
\hline & & \\
\hline & & \\
\hline
\end{tabular}

\section{SITE INSPECTION PREPARATION}

Assemble the following, as needed, to conduct inspections:

a. Radio, pager, etc.

b. Previous letter report, inspection checklists, repair records, and as-built plans

c. Other miscellaneous support equipment

\section{SITE INSPECTION}

1. Site markers:

a. Is there damage to the fence?

b. Have any posts been damaged or their anchoring weakened?

c. Are any of the 6 use restriction signs damaged or missing?

d. Are all use restriction signs legible?

e. How many signs need to be replaced?

\begin{tabular}{|l|l|l|}
\hline YES & NO & EXPLANATION (required if shaded box is checked) \\
\hline & & \\
\hline & & \\
\hline & & \\
\hline & & \\
\hline
\end{tabular}




\section{POST-CLOSURE INSPECTION CHECKLIST}

\section{CAU 137: WASTE DISPOSAL SITES - CAS 07-23-02, RADIOACTIVE WASTE DISPOSAL SITE}

2. Photograph Documentation (optional):

a. Have photographs been taken of the site?

If yes, how many photos were taken?

If yes, has a photographic log been prepared?

\section{E. FIELD CONCLUSIONS}

1. Are more frequent inspections required?

2. Are existing maintenance/repair actions satisfactory?

3. Is other maintenance/repair necessary?

4. Field conclusions/recommendations:

\begin{tabular}{|c|c|c|}
\hline YES & NO & EXPLANATION \\
\hline \multicolumn{2}{|c|}{2} & \\
\hline & & 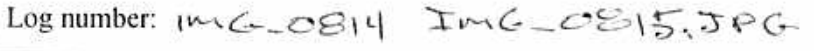 \\
\hline
\end{tabular}

. Sitc is im

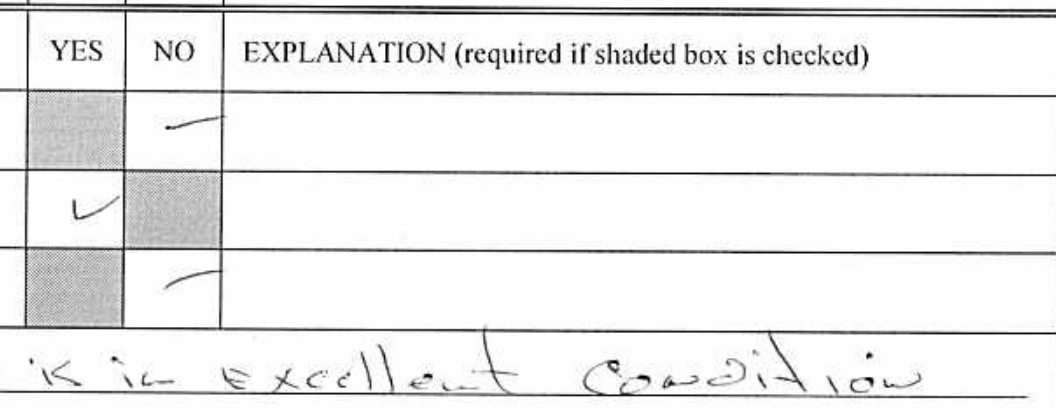

\section{F. CERTIFICATION}

I have conducted an inspection of CAS 07-23-02, Radioactive Waste Disposal Site, in accordance with the procedures of the Post-Closure Plan as recorded on this checklist, attached sheets, field notes, photographs, and photegraph logs.

\begin{tabular}{|l|l|}
\hline Chief Inspector's Signature: /s/G Richardson & Date: $1 / / 4 / 08$ \\
\hline Printed Name: Glenn Kichardson & Title: Task Manager
\end{tabular} 


\begin{tabular}{|c|c|}
\hline \multicolumn{2}{|c|}{ POST-CLOSURE INSPECTION CHECKLIST } \\
\hline \multicolumn{2}{|c|}{$\begin{aligned} & \text { CAU 137: WASTE DISPOSAL SITES - } \text { CAS 12-08-01, WASTE DISPOSAL SITE } \\
& \text { CAS 12-23-07, WASTE DISPOSAL SITE } \\
&\end{aligned}$} \\
\hline Inspection Date and Time: $16 / 27 / 08$ & Reason for Inspection: $\mathrm{A}, \mathrm{H}_{\mathrm{C}, \mathrm{S}}$ \\
\hline Date of Last Post-Closure Inspection: & Reason for Last Post-Closure Inspection: \\
\hline
\end{tabular}

Responsible Entity: NSTec Environmental Restoration, Nevada Test Site, Mercury, Nevada

Responsible Facility Owner: Thomas A. Thiele, Project Manager, Industrial Sites, Environmental Restoration Project

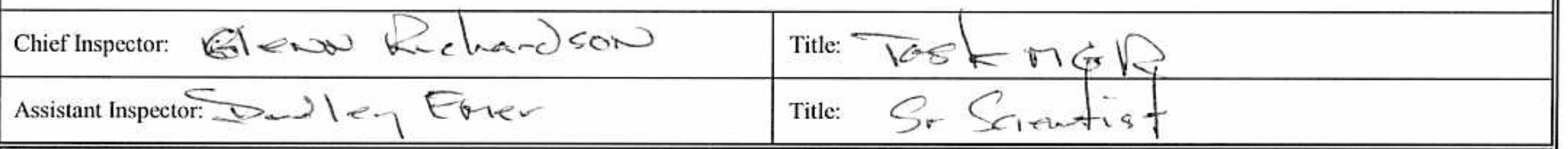

A. GENERAL INSTRUCTIONS

1. All checklist items must be completed and detailed comments made to document the results of the site inspection. The completed checklist is part of the field record of the inspection. Additional pages should be used as necessary to ensure that a complete record is made. Attach the additional pages and number all pages upon completion of the inspection.

2. Any checklist line item marked by an inspector in a SHADED BOX must be fully explained or an appropriate reference to previous reports provided. The purpose of this requirement is to provide a written explanation of inspector observations and the inspector's rationale for conclusions and recommendations. Explanations are to be placed on additional attachments and cross-referenced appropriately. Explanations, in addition to narrative, will take the form of sketches, measurements, and annotated site maps.

3. The site inspection is a walking inspection of the entire site including the perimeter and sufficient transects to be able to inspect the entire surface and all features specifically described in this checklist.

4. Field notes taken to assist in completion of this checklist will become part of the inspection record. No form is specified for field notes; however, they must be legible and in sufficient detail to enable review by succeeding inspectors and the responsible agency.

5. This unit will be inspected annually with formal reporting to the Nevada Division of Environmental Protection to be done annually. The annual letter report will include a summary with this inspection checklist attached.

\begin{tabular}{|l|l|l|l|}
\hline B. PREPARATION (To be competed prior to site visit) & YES & NO & EXPLANATION (required if shaded box is checked) \\
\hline 1. Has the Post-Closure Plan been reviewed? & & & \\
2. Have the previous inspection reports been reviewed? & & & \\
\cline { 2 - 4 } 3. Were anomalies or trends detected on previous inspections? & & & \\
\cline { 2 - 4 } 4. Were maintenance or repairs performed since last inspection? & & & \\
\cline { 2 - 4 } & &
\end{tabular}

\section{SITE INSPECTION PREPARATION}

Assemble the following, as needed, to conduct inspections:

a. Radio, pager, etc.

b. Previous letter report, inspection checklists, repair records, and as-built plans

c. Other miscellaneous support equipment

\section{SITE INSPECTION}

1. Site markers:

a. Is there damage to the fence?

b. Have any posts been damaged or their anchoring weakened?

c. Are any of the 8 use restriction signs damaged or missing?

d. Are all use restriction signs legible?

e. How many signs need to be replaced?

\begin{tabular}{|l|l|l||}
\hline YES & NO & EXPLANATION (required if shaded box is checked) \\
\hline & 4 & \\
\hline & 4 & \\
\hline & 4 & \\
\hline & & \\
\hline
\end{tabular}




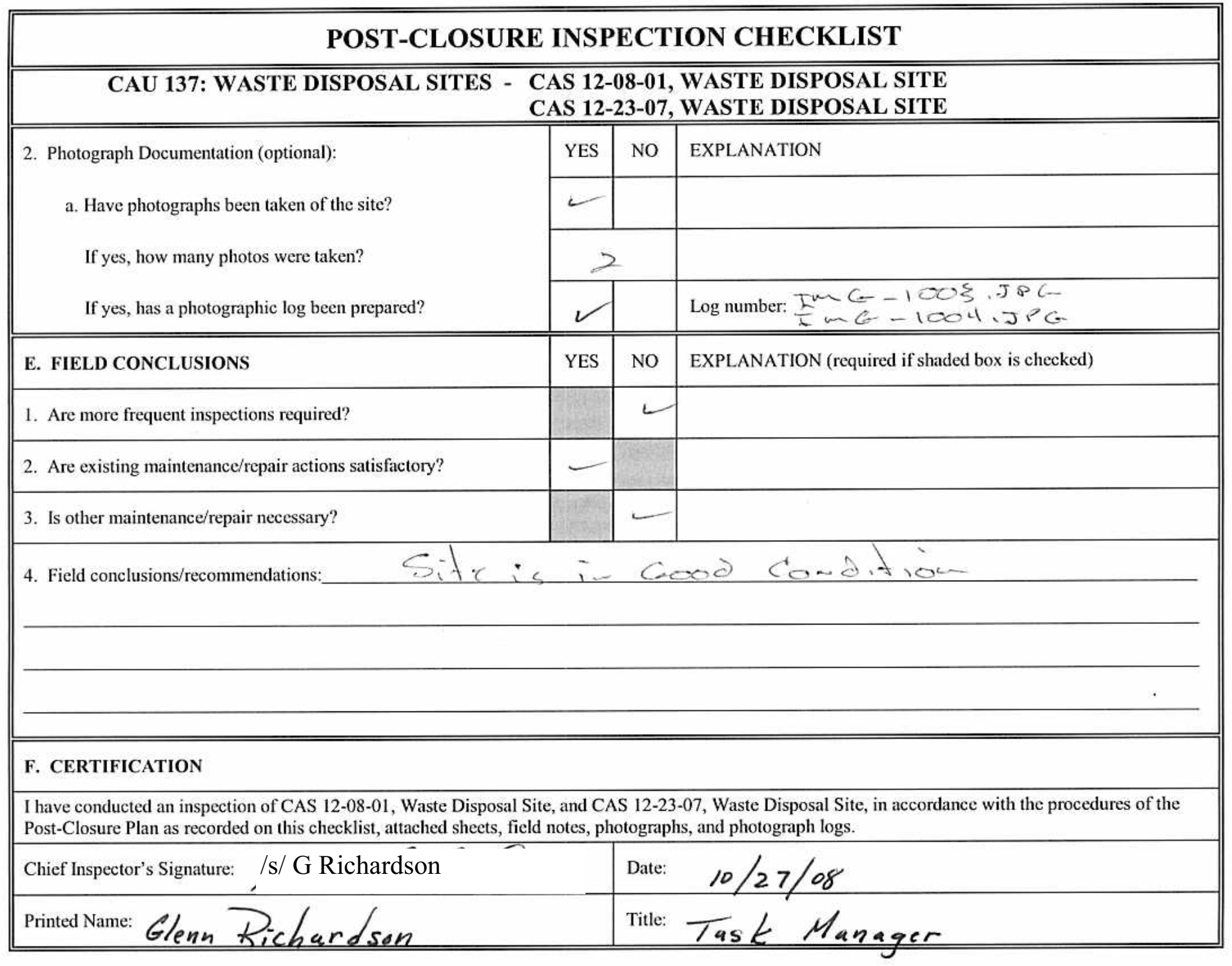


CAU 140: WASTE DUMPS, BURN PITS, AND STORAGE AREA 
THIS PAGE INTENTIONALLY LEFT BLANK 


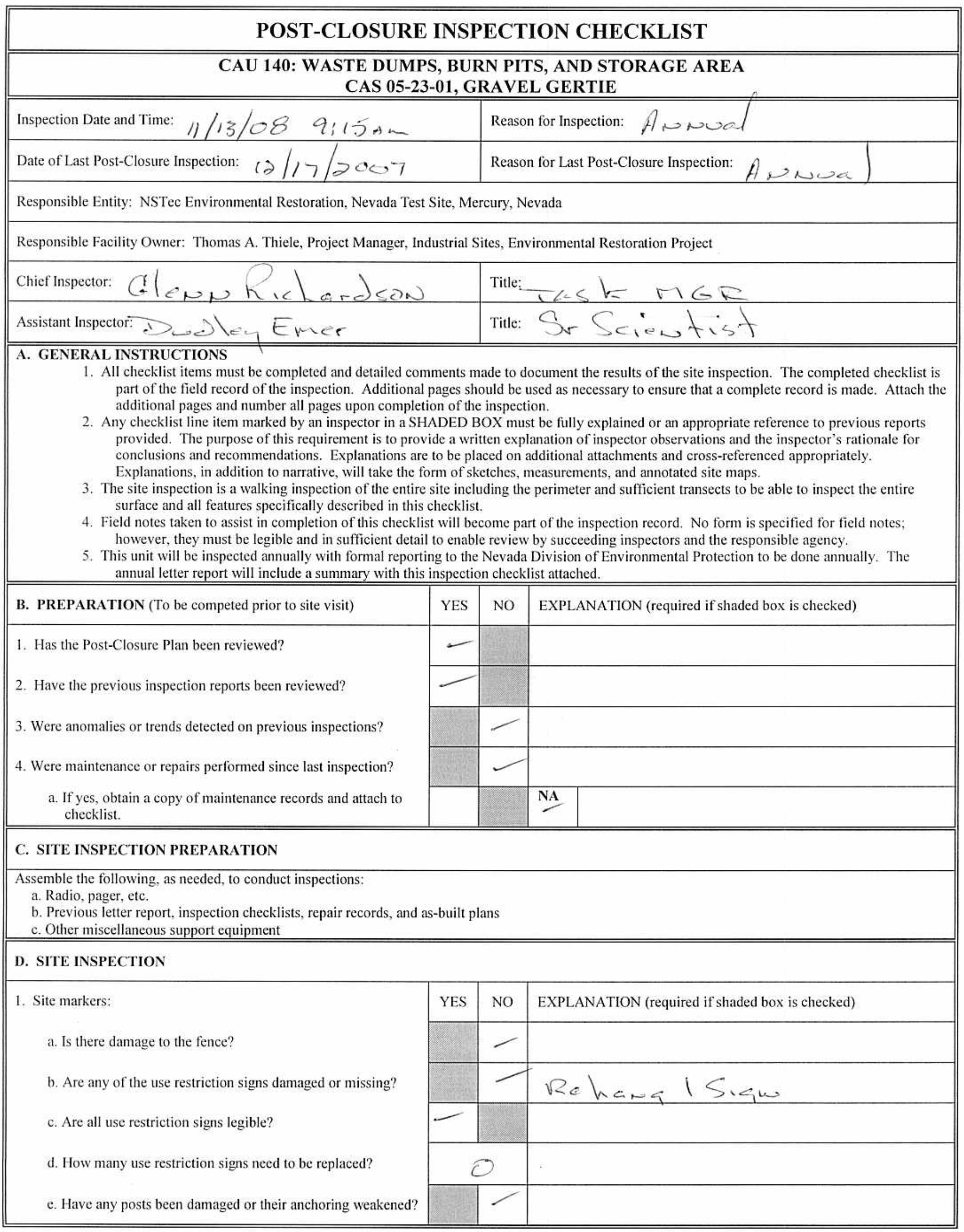




\begin{tabular}{|c|c|c|c|}
\hline \multicolumn{4}{|c|}{ POST-CLOSURE INSPECTION CHECKLIST } \\
\hline \multicolumn{4}{|c|}{$\begin{array}{l}\text { CAU 140: WASTE DUMPS, BURN PITS, AND STORAGE AREA } \\
\text { CAS 05-23-01, GRAVEL GERTIE } \\
\end{array}$} \\
\hline \multirow{2}{*}{$\begin{array}{l}\text { 1. Site markers (continued): } \\
\text { f. Are any of the URMA signs damaged or missing? }\end{array}$} & YES & NO & EXPLANATION (required if shaded box is checked) \\
\hline & & & \\
\hline \multicolumn{4}{|l|}{ g. Are all URMA signs legible? } \\
\hline \multicolumn{4}{|l|}{ h. How many URMA signs need to be replaced? } \\
\hline \multirow{2}{*}{$\begin{array}{l}\text { 2. Use-restricted area: } \\
\text { a. Is there evidence of human intrusion onto the site? }\end{array}$} & YES & NO & EXPLANATION (required if shaded box is checked) \\
\hline & & & \\
\hline 3. Photograph Documentation: & YES & NO & EXPLANATION (required if shaded box is checked) \\
\hline \multicolumn{4}{|l|}{ a. Have photographs been taken of the site? } \\
\hline If yes, how many photos were taken? & \multicolumn{2}{|c|}{7} & \\
\hline If yes, has a photographic log been prepared? & & & Log number: $1 \mathrm{~m} G-0805-0806,5 \circ \mathrm{G}$ \\
\hline E. FIELD CONCLUSIONS & YES & NO & EXPLANATION (required if shaded box is checked) \\
\hline \multicolumn{4}{|l|}{ 1. Are more frequent inspections required? } \\
\hline \multicolumn{4}{|l|}{ 2. Are existing maintenance/repair actions satisfactory? } \\
\hline 3. Is other maintenance/repair necessary? & 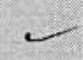 & · & 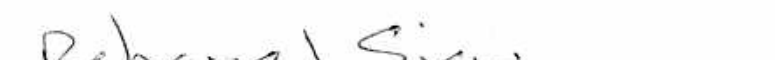 \\
\hline \multicolumn{4}{|c|}{ 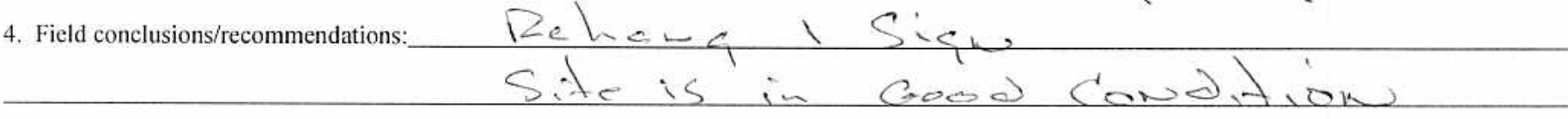 } \\
\hline \multicolumn{4}{|l|}{ F. CERTIFICATION } \\
\hline \multicolumn{4}{|c|}{$\begin{array}{l}\text { I have conducted an inspection of CAS 05-23-01, Gravel Gertie, in accordance with the procedures of the Post-Closure Plan as recorded on this checklist, } \\
\text { attached sheets, field notes, photographs, and photograph logs. }\end{array}$} \\
\hline \multicolumn{2}{|l|}{ Chief Inspector's Signature: /s/ G Richardson } & Date: & \\
\hline Printed Name: Glenn Richardson & & Title: & Task Manager \\
\hline
\end{tabular}

Attachments (check if attached):

$\square$ Maintenance records

$\square$ Photos

$\square$ Field Notes 


\begin{tabular}{|c|c|c|c|}
\hline \multicolumn{4}{|c|}{ POST-CLOSURE INSPECTION CHECKLIST } \\
\hline \multicolumn{4}{|c|}{$\begin{array}{l}\text { CAU 140: WASTE DUMPS, BURN PITS, AND STORAGE AREA } \\
\text { CAS 23-17-01, HAZARDOUS WASTE STORAGE AREA } \\
\end{array}$} \\
\hline \multicolumn{2}{|l|}{ Inspection Date and Time: } & \multicolumn{2}{|c|}{ Reason for Inspection: Annua/ } \\
\hline \multicolumn{2}{|l|}{ Date of Last Post-Closure Inspection: $\quad 1 / 23 / 08$} & \multicolumn{2}{|c|}{ Reason for Last Post-Closure Inspection: $A n и и a /$} \\
\hline \multicolumn{4}{|c|}{ Responsible Entity: NSTec Environmental Restoration, Nevada Test Site, Mercury, Nevada } \\
\hline \multicolumn{4}{|c|}{ Responsible Facility Owner: Thomas A. Thiele, Project Manager, Industrial Sites, Environmental Restoration Project } \\
\hline \multicolumn{2}{|l|}{ Chief Inspector: Glenn Richardson } & \multicolumn{2}{|c|}{ Title: Task Manager } \\
\hline \multicolumn{2}{|l|}{ Assistant Inspector: Chris Mc Gowin } & \multicolumn{2}{|c|}{ Title: Field Technical Lead } \\
\hline \multicolumn{4}{|c|}{$\begin{array}{l}\text { A. GENERAL INSTRUCTIONS } \\
\text { 1. All checklist items must be completed and detailed comments made to document the results of the site inspection. The completed checklist is } \\
\text { part of the field record of the inspection. Additional pages should be used as necessary to ensure that a complete record is made. Attach the } \\
\text { additional pages and number all pages upon completion of the inspection. } \\
\text { 2. Any checklist line item marked by an inspector in a SHADED BOX must be fully explained or an appropriate reference to previous reports } \\
\text { provided. The purpose of this requirement is to provide a written explanation of inspector observations and the inspector's rationale for } \\
\text { conclusions and recommendations. Explanations are to be placed on additional attachments and cross-referenced appropriately. } \\
\text { Explanations, in addition to narrative, will take the form of sketches, measurements, and annotated site maps. } \\
\text { 3. The site inspection is a walking inspection of the entire site including the perimeter and sufficient transects to be able to inspect the entire } \\
\text { surface and all features specifically described in this checklist. } \\
\text { 4. Field notes taken to assist in completion of this checklist will become part of the inspection record. No form is specified for field notes; } \\
\text { however, they must be legible and in sufficient detail to enable review by succeeding inspectors and the responsible agency. } \\
\text { 5. This unit will be inspected annually with formal reporting to the Nevada Division of Environmental Protection to be done annually. The } \\
\text { annual letter report will include a summary with this inspection checklist attached. }\end{array}$} \\
\hline B. PREPARATION (To be competed prior to site visit) & YES & NO & EXPLANATION (required if shaded box is checked) \\
\hline \multicolumn{4}{|l|}{ 1. Has the Post-Closure Plan been reviewed? } \\
\hline \multicolumn{4}{|l|}{ 2. Have the previous inspection reports been reviewed? } \\
\hline \multicolumn{4}{|l|}{ 3. Were anomalies or trends detected on previous inspections? } \\
\hline \multirow{2}{*}{$\begin{array}{l}\text { 4. Were maintenance or repairs performed since last inspection? } \\
\text { a. If yes, obtain a copy of maintenance records and attach to } \\
\text { checklist. }\end{array}$} & & & $\begin{array}{l}\text { Sign omaintenance was performed and completed } \\
\text { on } 8 / 14 / 08 \text {. }\end{array}$ \\
\hline & & & NA \\
\hline \multicolumn{4}{|l|}{ C. SITE INSPECTION PREPARATION } \\
\hline \multicolumn{4}{|c|}{$\begin{array}{l}\text { Assemble the following, as needed, to conduct inspections: } \\
\text { a. Radio, pager, etc. } \\
\text { b. Previous letter report, inspection checklists, repair records, and as-built plans } \\
\text { c. Other miscellaneous support equipment } \\
\end{array}$} \\
\hline \multicolumn{4}{|l|}{ D. SITE INSPECTION } \\
\hline \multirow{5}{*}{$\begin{array}{l}\text { 1. Site markers (TPH Area): } \\
\text { a. Have any posts been damaged or their anchoring weakened }\end{array}$} & YES & NO & EXPLANATION (required if shaded box is checked) \\
\hline & & & \\
\hline & & & \\
\hline & & & \\
\hline & & & \\
\hline
\end{tabular}




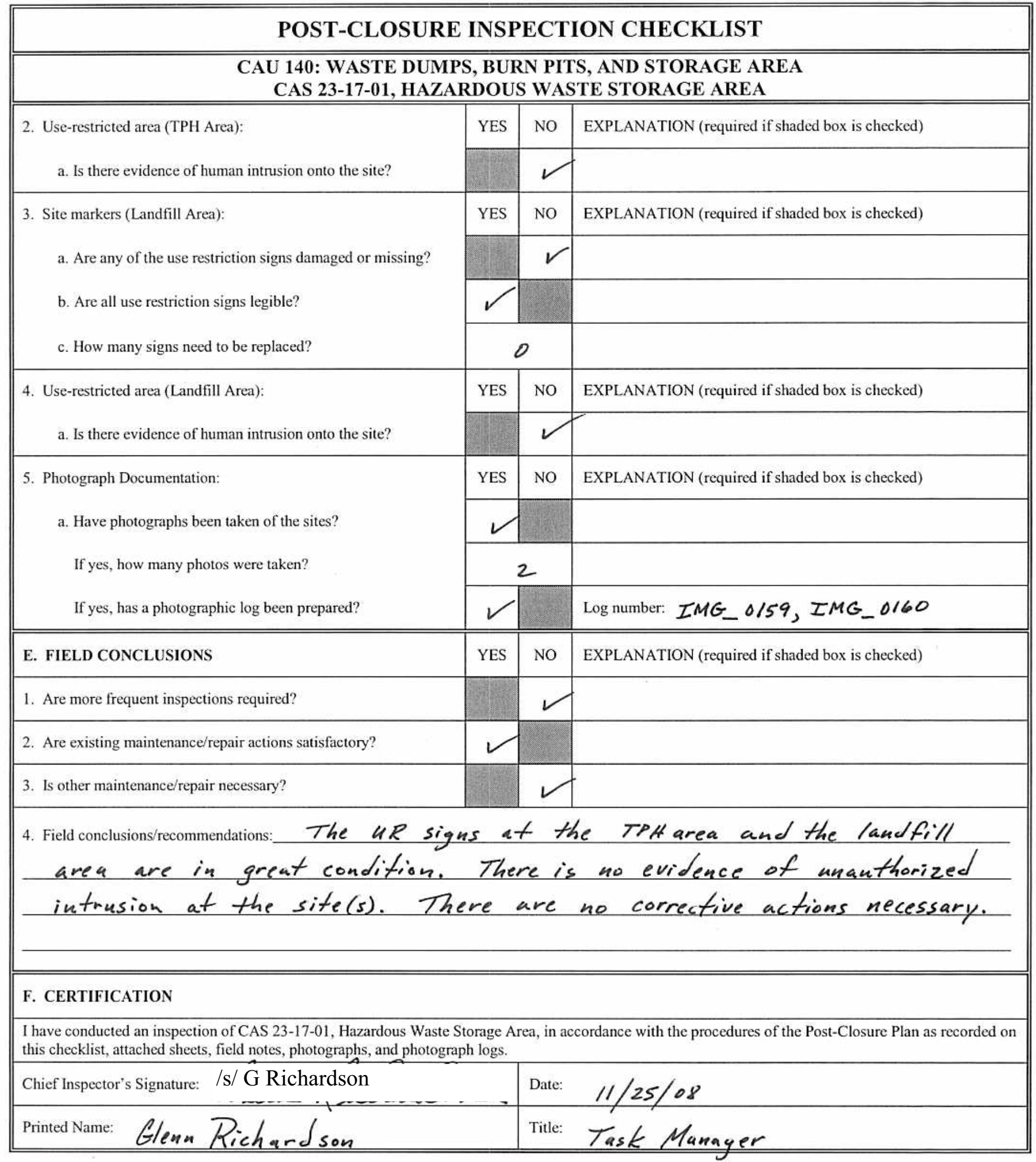

Attachments (check if attached):

$\square$ Maintenance records

$\square$ Photos

$\square$ Field notes 
CAU 143: AREA 25 CONTAMINATED WASTE DUMPS 
THIS PAGE INTENTIONALLY LEFT BLANK 


\section{POST-CLOSURE INSPECTION CHECKLIST}

\section{CAU 143: AREA 25 CONTAMINATED WASTE DUMPS CAS 25-23-03, CONTAMINATED WASTE DUMP \#2}

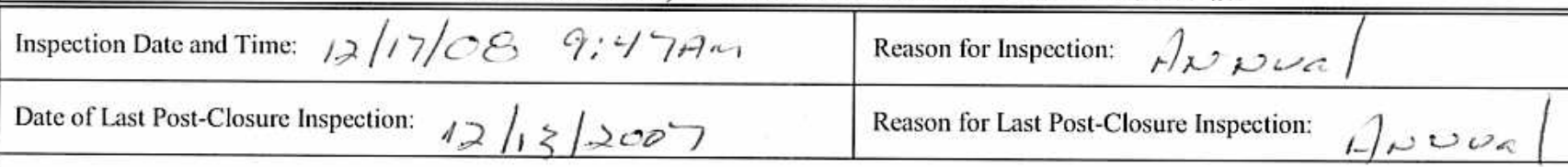

Responsible Entity: NSTec Environmental Restoration, Nevada Test Site, Mercury, Nevada

Responsible Facility Owner: Thomas A. Thiele, Project Manager, Industrial Sites, Environmental Restoration Project

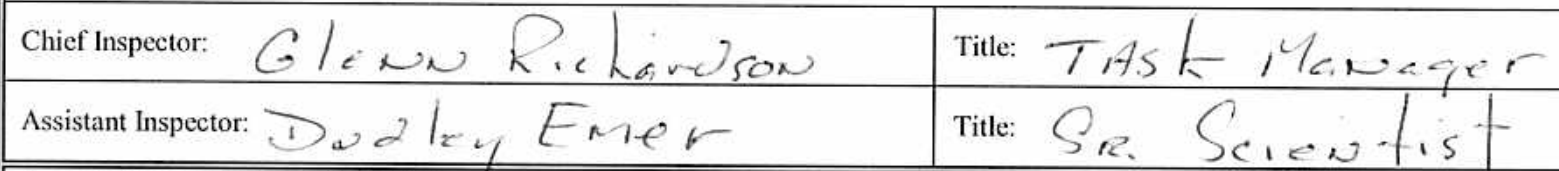

A. GENERAL INSTRUCTIONS

1. All checklist items must be completed and detailed comments made to document the results of the site inspection. The completed checklist is part of the field record of the inspection. Additional pages should be used as necessary to ensure that a complete record is made. Attach the additional pages and number all pages upon completion of the inspection.

2. Any checklist line item marked by an inspector in a SHADED BOX must be fully explained or an appropriate reference to previous reports provided. The purpose of this requirement is to provide a written explanation of inspector observations and the inspector's rationale for conclusions and recommendations. Explanations are to be placed on additional attachments and cross-referenced appropriately. Explanations, in addition to narrative, will take the form of sketches, measurements, and annotated site maps.

3. The site inspection is a walking inspection of the entire site including the perimeter and sufficient transects to be able to inspect the entire surface and all features specifically described in this checklist.

4. Field notes taken to assist in completion of this checklist will become part of the inspection record. No form is specified for field notes; however, they must be legible and in sufficient detail to enable review by succeeding inspectors and the responsible agency.

5. This unit will be inspected annually with formal reporting to the Nevada Division of Environmental Protection to be done annually. The annual letter report will include a summary with this inspection checklist attached.

B. PREPARATION (To be competed prior to site visit)

1. Has the Post-Closure Plan been reviewed?

2. Have the previous inspection reports been reviewed?

3. Were anomalies or trends detected on previous inspections?

4. Were maintenance or repairs performed since last inspection?

a. If yes, obtain a copy of maintenance records and attach to checklist.

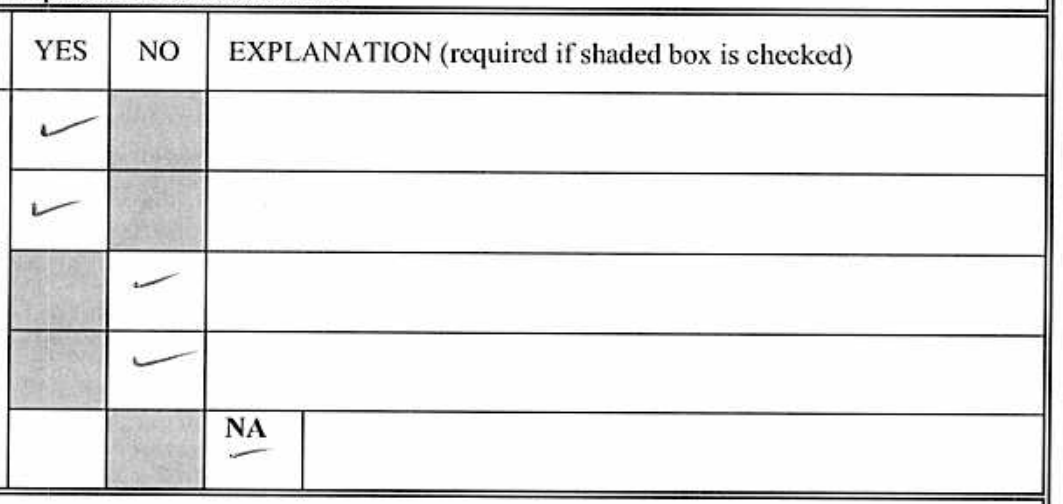

\section{SITE INSPECTION PREPARATION}

Assemble the following, as needed, to conduct inspections:

a. Radio, pager, etc.

b. Previous letter report, inspection checklists, repair records, and as-built plans

c. Other miscellaneous support equipment

\section{SITE INSPECTION}

1. Site markers:

a. Is there damage to the fence?

b. Have any posts been damaged or their anchoring weakened?

c. Are any of the 17 "Caution-Underground Radioactive Material" signs damaged or missing?

d. Are all signs legible?

e. How many signs need to be replaced?

\begin{tabular}{|l|l|l||}
\hline YES & NO & EXPLANATION (required if shaded box is checked) \\
\hline & 4 & \\
\hline & 4 & \\
\hline & & \\
\hline 2 & 15.5020000 \\
\hline
\end{tabular}




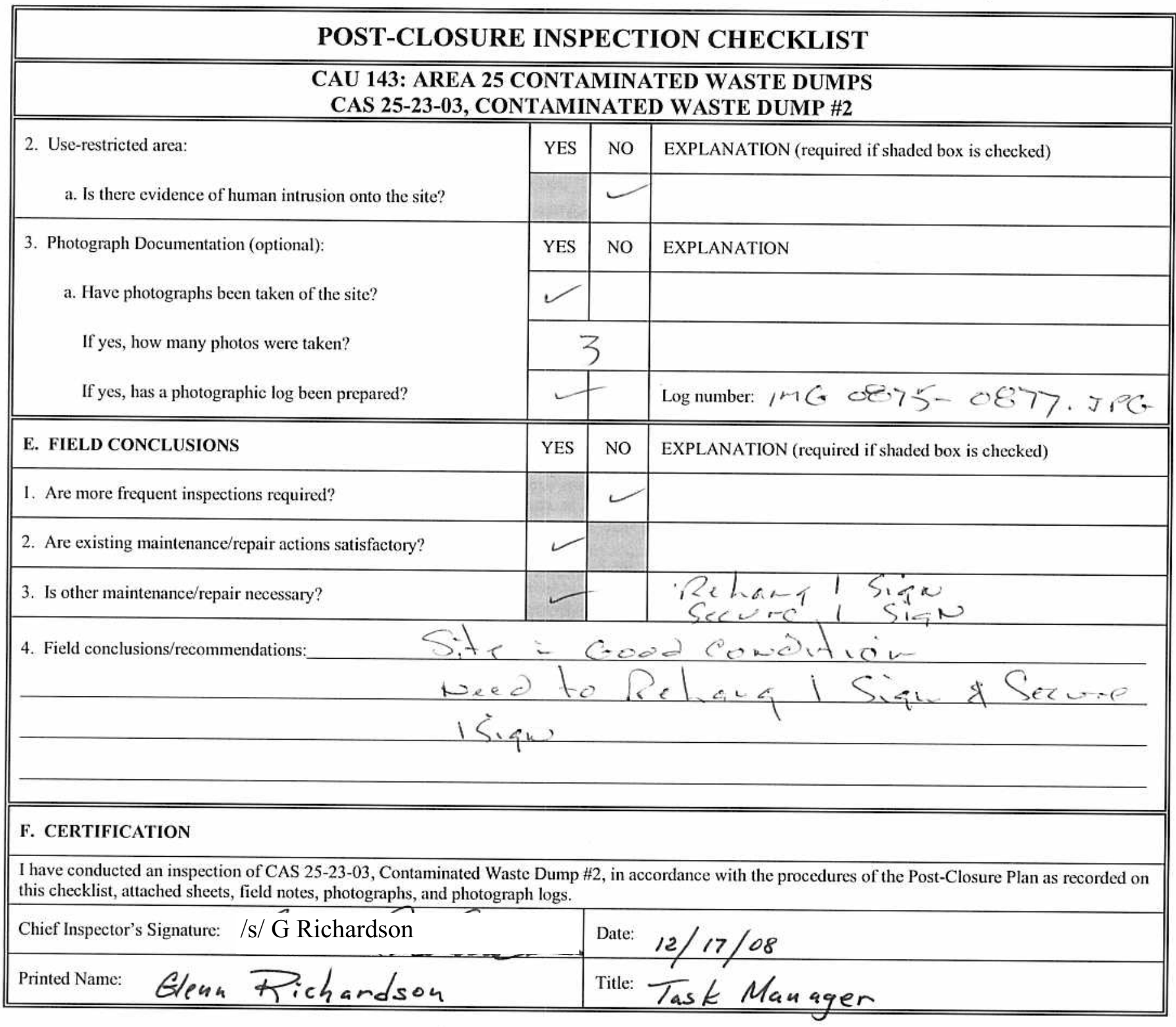

Attachment: Maintenance records (check if attached) 


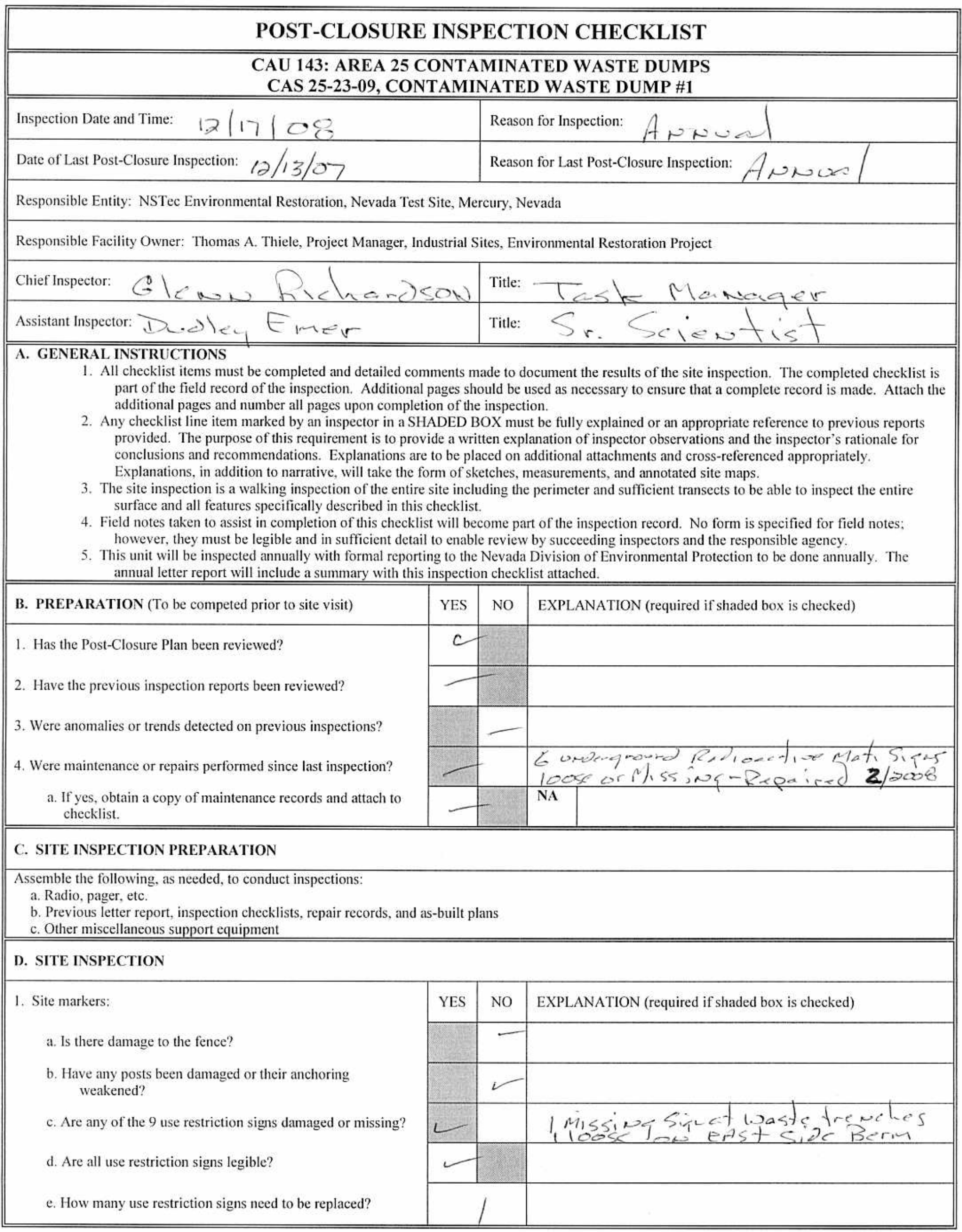




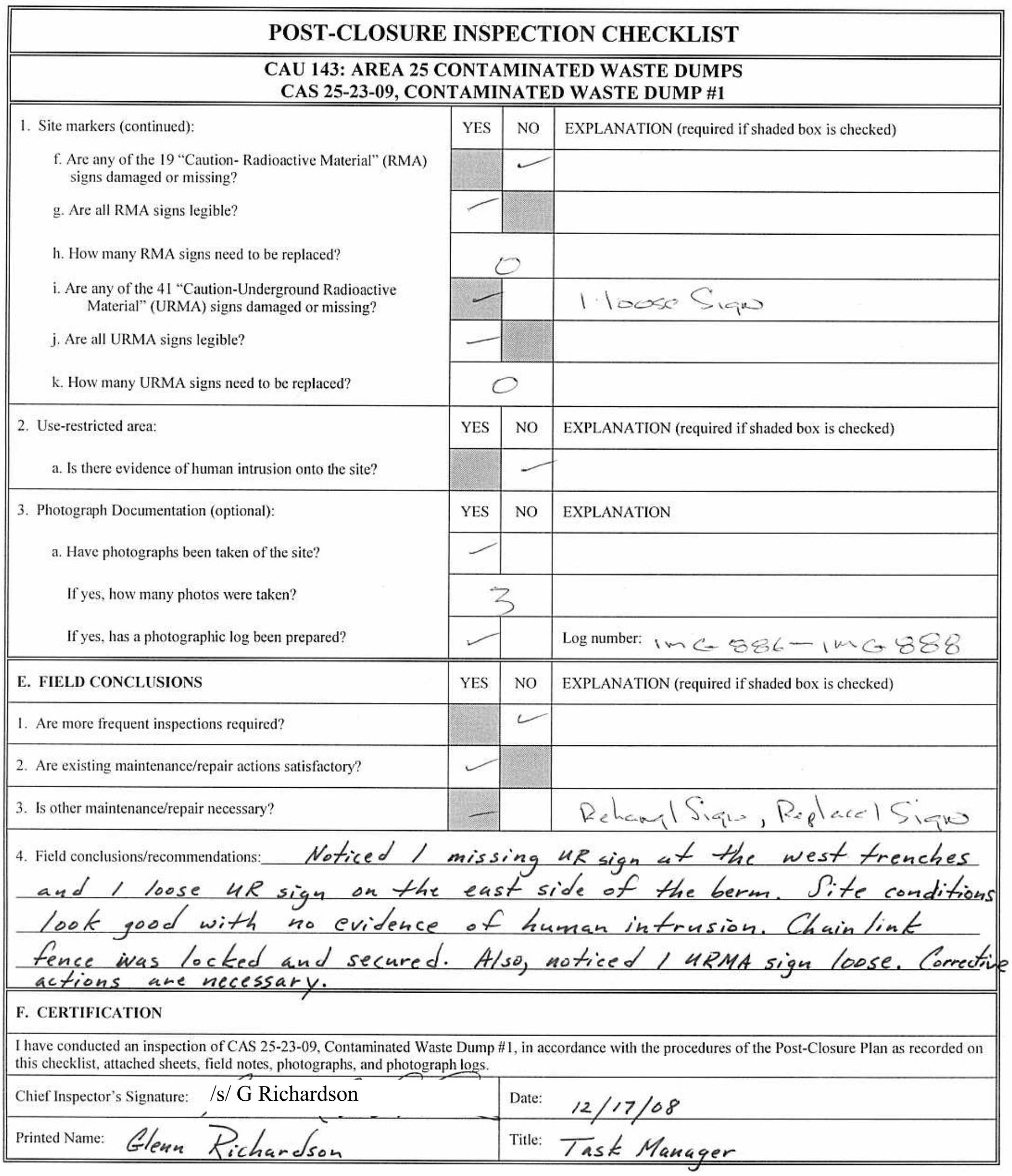

Attachment: Maintenance records (check if attached) 
CAU 145: WELLS AND STORAGE HOLES 
THIS PAGE INTENTIONALLY LEFT BLANK 


\section{POST-CLOSURE INSPECTION CHECKLIST}

\section{CAU 145: WELLS AND STORAGE HOLES - CAS 03-25-01, OIL SPILLS}

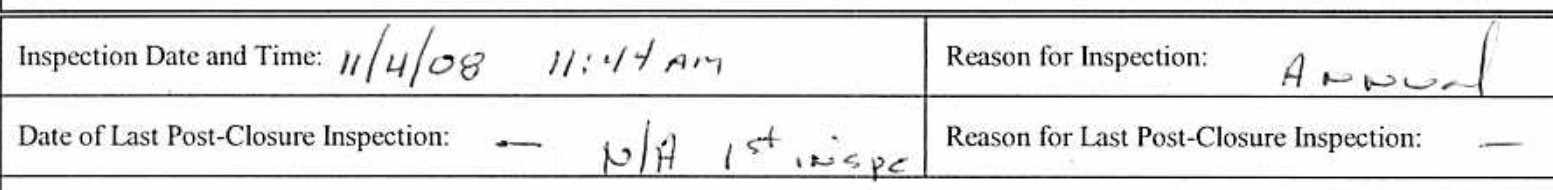

Responsible Entity: NSTec Environmental Restoration, Nevada Test Site, Mercury, Nevada

Responsible Facility Owner: Thomas A. Thiele, Project Manager, Industrial Sites, Environmental Restoration Project

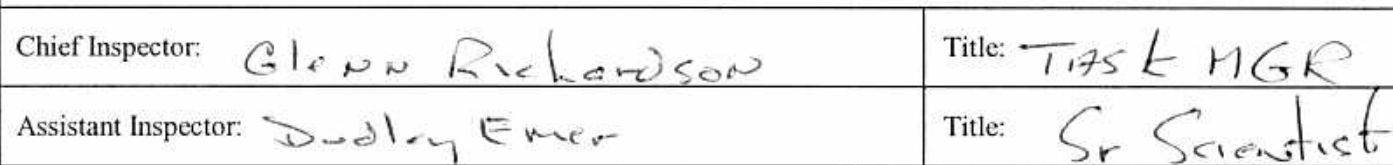

\section{A. GENERAL INSTRUCTIONS}

1. All checklist items must be completed and detailed comments made to document the results of the site inspection. The completed checklist is part of the field record of the inspection. Additional pages should be used as necessary to ensure that a complete record is made. Attach the additional pages and number all pages upon completion of the inspection.

2. Any checklist line item marked by an inspector in a SHADED BOX must be fully explained or an appropriate reference to previous reports provided. The purpose of this requirement is to provide a written explanation of inspector observations and the inspector's rationale for conclusions and recommendations. Explanations are to be placed on additional attachments and cross-referenced appropriately.

Explanations, in addition to narrative, will take the form of sketches, measurements, and annotated site maps.

3. The site inspection is a walking inspection of the entire site including the perimeter and sufficient transects to be able to inspect the entire surface and all features specifically described in this checklist.

4. Field notes taken to assist in completion of this checklist will become part of the inspection record. No form is specified for field notes; however, they must be legible and in sufficient detail to enable review by succeeding inspectors and the responsible agency.

5. This unit will be inspected annually with formal reporting to the Nevada Division of Environmental Protection to be done annually. The annual letter report will include a summary with this inspection checklist attached.

\begin{tabular}{|c|c|c|c|}
\hline B. PREPARATION (To be competed prior to site visit) & YES & NO & EXPLANATION (required if shaded box is checked) \\
\hline 1. Has the Post-Closure Plan been reviewed? & & & \\
\hline 2. Have the previous inspection reports been reviewed? & & & 1st inspection $\mathrm{N} / \mathrm{A}$ \\
\hline 3. Were anomalies or trends detected on previous inspections? & & & $\cdots$ \\
\hline 4. Were maintenance or repairs performed since last inspection? & & & 1 \\
\hline
\end{tabular}

\section{SITE INSPECTION PREPARATION}

Assemble the following, as needed, to conduct inspections:

a. Radio, pager, etc.

b. Previous letter report, inspection checklists, repair records, and as-built plans

c. Other miscellaneous support equipment

\section{SITE INSPECTION}

1. Site markers:

a. Have any posts been damaged or their anchoring weakened?

b. Are any of the six (6) use restriction signs damaged or missing?

c. Are all use restriction signs legible?

d. How many signs need to be replaced?

2. Use-restricted area:

a. Is there evidence of human intrusion onto the site? 


\section{POST-CLOSURE INSPECTION CHECKLIST}

\section{CAU 145: WELLS AND STORAGE HOLES - CAS 03-25-01, OIL SPILLS}

\begin{tabular}{|c|c|c|c|}
\hline \multirow{2}{*}{$\begin{array}{l}\text { 3. Photograph Documentation (optional): } \\
\text { a. Have photographs been taken of the site? }\end{array}$} & YES & NO & EXPLANATION \\
\hline & & & \\
\hline If yes, how many photos were taken? & 1 & & \\
\hline If yes, has a photographic log been prepared? & & & Log number:,$\neg C-\triangle \neg \& 0 . J P C$ \\
\hline E. FIELD CONCLUSIONS & YES & NO & EXPLANATION (required if shaded box is checked) \\
\hline 1. Are more frequent inspections required? & & ᄂ & \\
\hline 2. Are existing maintenance/repair actions satisfactory? & - & & \\
\hline 3. Is other maintenance/repair necessary? & & & \\
\hline
\end{tabular}

\section{F. CERTIFICATION}

I have conducted an inspection of CAS 03-25-01, Oil Spills, in accordance with the procedures of the Post-Closure Plan as recorded on this checklist, attached sheets, field notes, photographs, and photograph logs.

\begin{tabular}{ll|l} 
Chief Inspector's Signature: /s/G Richardson & Date: $11 / 04 / 08$ \\
\hline Printed Name: Glenn Kichardson & Title: Task Manager
\end{tabular}


CAU 151: SEPTIC SYSTEMS AND DISCHARGE AREA 
THIS PAGE INTENTIONALLY LEFT BLANK 
POST-CLOSURE INSPECTION CHECKLIST

\section{CAU 151: SEPTIC SYSTEMS AND DISCHARGE AREA - CAS 12-03-01, SEWAGE LAGOONS (6) (LAGOON A ONLY)}

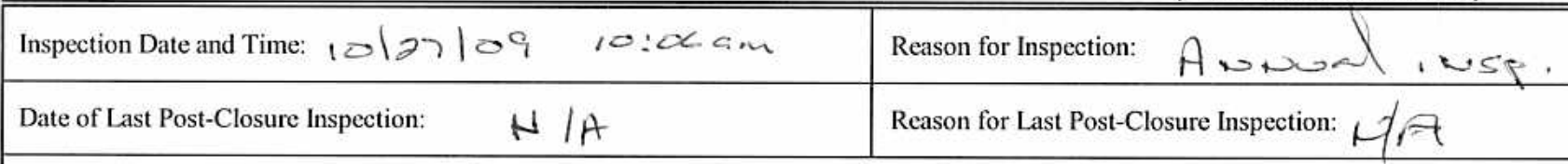

Responsible Entity: NSTec Environmental Restoration, Nevada Test Site, Mercury, Nevada

Responsible Facility Owner: Thomas A. Thiele, Project Manager, Industrial Sites, Environmental Restoration Project

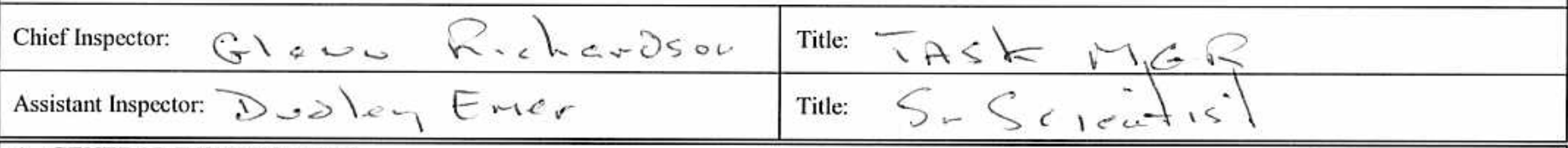

\section{A. GENERAL INSTRUCTIONS}

1. All checklist items must be completed and detailed comments made to document the results of the site inspection. The completed checklist is part of the field record of the inspection. Additional pages should be used as necessary to ensure that a complete record is made. Attach the additional pages and number all pages upon completion of the inspection.

2. Any checklist line item marked by an inspector in a SHADED BOX must be fully explained or an appropriate reference to previous reports provided. The purpose of this requirement is to provide a written explanation of inspector observations and the inspector's rationale for conclusions and recommendations. Explanations are to be placed on additional attachments and cross-referenced appropriately. Explanations, in addition to narrative, will take the form of sketches, measurements, and annotated site maps.

3. The site inspection is a walking inspection of the entire site including the perimeter and sufficient transects to be able to inspect the entire surface and all features specifically described in this checklist.

4. Field notes taken to assist in completion of this checklist will become part of the inspection record. No form is specified for field notes; however, they must be legible and in sufficient detail to enable review by succeding inspectors and the responsible agency.

5. This unit will be inspected annually with formal reporting to the Nevada Division of Environmental Protection to be done annually. The annual letter report will include a summary with this inspection checklist attached.

\section{B. PREPARATION (To be competed prior to site visit)}

1. Has the Post-Closure Plan been reviewed?

2. Have the previous inspection reports been reviewed?

3. Were anomalies or trends detected on previous inspections?

4. Were maintenance or repairs performed since last inspection?

\begin{tabular}{|c|c|c|}
\hline YES & NO & EXPLANATION (required if shaded box is checked) \\
\hline & & 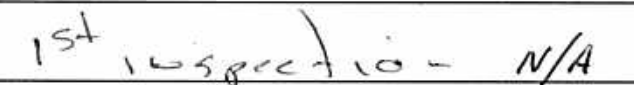 \\
\hline & & $\iota \checkmark$ \\
\hline & & 1 \\
\hline
\end{tabular}

\section{SITE INSPECTION PREPARATION}

Assemble the following, as needed, to conduct inspections:

a. Radio, pager, etc.

b. Previous letter report, inspection checklists, repair records, and as-built plans

c. Other miscellaneous support equipment

\section{SITE INSPECTION}

1. Site markers:

b. Have any posts been damaged or their anchoring weakened?

c. Are any of the six (6) use restriction signs damaged or missing?

d. Are all use restriction signs legible?

e. How many signs need to be replaced?

2. Use-restricted area:

a. Is there evidence of human intrusion onto the site?

\begin{tabular}{|r|l|l||}
\hline YES & NO & EXPLANATION (required if shaded box is checked) \\
\hline & & \\
\hline & & \\
\hline YES & NO & EXPLANATION (required if shaded box is checked) \\
\hline & & \\
\hline
\end{tabular}

Page 1 of 2 


\section{POST-CLOSURE INSPECTION CHECKLIST}

\section{CAU 151: SEPTIC SYSTEMS AND DISCHARGE AREA - CAS 12-03-01, SEWAGE LAGOONS (6)}

3. Photograph Documentation (optional):

a. Have photographs been taken of the site?

If yes, how many photos were taken?

If yes, has a photographic log been prepared?

\begin{tabular}{||l|l|l|l}
\hline \hline E. FIELD CONCLUSIONS & YES & NO & EXPLANATION (required if shaded box is checked) \\
\hline 1. Are more frequent inspections required? & & & \\
\hline 2. Are existing maintenance/repair actions satisfactory? & & \\
\hline 3. Is other maintenance/repair necessary? &
\end{tabular}

\section{F. CERTIFICATION}

I have conducted an inspection of CAS 12-03-01, Sewage Lagoons (6), in accordance with the procedures of the Post-Closure Plan as recorded on this checklist, attached sheets, field notes, photographs, and photograph logs.

Chief Inspector's Signature: /s/ G Richardson $\quad$ Date: $10 / 27 / 08$

Printed Name: 
CAU 165: AREA 25 AND 26 DRY WELL AND WASHDOWN AREAS 
THIS PAGE INTENTIONALLY LEFT BLANK 


\section{POST-CLOSURE INSPECTION CHECKLIST}

\section{CAU 165: AREA 25 AND 26 DRY WELL AND WASHDOWN AREAS CAS 25-20-01, LAB DRAIN DRY WELL}

\begin{tabular}{|l|l|}
\hline \hline Inspection Date and Time: $12 / 03 / 08 \quad / 1: 34 A M$ & Reason for Inspection: Annua $/$ \\
\hline Date of Last Post-Closure Inspection: $12 / 13 / 07$ & Reason for Last Post-Closure Inspection: Annua/ \\
\hline Ren:
\end{tabular}

Responsible Entity: NSTec Environmental Restoration, Nevada Test Site, Mercury, Nevada

Responsible Facility Owner: Thomas A. Thiele, Project Manager, Industrial Sites, Environmental Restoration Project

\begin{tabular}{l|l}
\hline Chief Inspector: Glemn Richardson & Title: Task Manager \\
\hline Assistant Inspector: Dudley Emer & Title: Sr. Scientist
\end{tabular}

A. GENERAL INSTRUCTIONS

1. All checklist items must be completed and detailed comments made to document the results of the site inspection. The completed checklist is part of the field record of the inspection. Additional pages should be used as necessary to ensure that a complete record is made. Attach the additional pages and number all pages upon completion of the inspection.

2. Any checklist line item marked by an inspector in a SHADED BOX must be fully explained or an appropriate reference to previous reports provided. The purpose of this requirement is to provide a written explanation of inspector observations and the inspector's rationale for conclusions and recommendations. Explanations are to be placed on additional attachments and cross-referenced appropriately.

Explanations, in addition to narrative, will take the form of sketches, measurements, and annotated site maps.

3. The site inspection is a walking inspection of the entire site including the perimeter and sufficient transects to be able to inspect the entire surface and all features specifically described in this checklist.

4. Field notes taken to assist in completion of this checklist will become part of the inspection record. No form is specified for field notes; however, they must be legible and in sufficient detail to enable review by succeeding inspectors and the responsible agency.

5. This unit will be inspected annually with formal reporting to the Nevada Division of Environmental Protection to be done annually. The annual letter report will include a summary with this inspection checklist attached.

B. PREPARATION (To be competed prior to site visit)

1. Has the Post-Closure Plan been reviewed?

2. Have the previous inspection reports been reviewed?

3. Were anomalies or trends detected on previous inspections?

4. Were maintenance or repairs performed since last inspection?

a. If yes, obtain a copy of maintenance records and attach to checklist.

\section{SITE INSPECTION PREPARATION}

Assemble the following, as needed, to conduct inspections:

a. Radio, pager, etc.

b. Previous letter report, inspection checklists, repair records, and as-built plans

c. Other miscellaneous support equipment

\section{SITE INSPECTION}

1. Site markers:

a. Have any posts been damaged or their anchoring weakened?

b. Are any of the use restriction signs damaged or missing?

c. Are all use restriction signs legible?

d. How many signs need to be replaced?

\begin{tabular}{|l|l|l||}
\hline YES & NO & EXPLANATION (required if shaded box is checked) \\
\hline & \multicolumn{1}{|c|}{} \\
\hline & & Noticed / UR sign down \\
\hline & & \\
\hline
\end{tabular}




\begin{tabular}{|c|c|c|c|}
\hline \multicolumn{4}{|c|}{ POST-CLOSURE INSPECTION CHECKLIST } \\
\hline \multicolumn{4}{|c|}{$\begin{array}{l}\text { CAU 165: AREA 25 AND 26 DRY WELL AND WASHDOWN AREAS } \\
\text { CAS 25-20-01, LAB DRAIN DRY WELL }\end{array}$} \\
\hline \multirow{2}{*}{$\begin{array}{l}\text { 2. Use-restricted area: } \\
\text { a. Is there evidence of human intrusion onto the site? }\end{array}$} & YES & NO & EXPLANATION (required if shaded box is checked) \\
\hline & & & \\
\hline \multirow{2}{*}{$\begin{array}{l}\text { 3. Photograph Documentation (optional): } \\
\text { a. Have photographs been taken of the site? }\end{array}$} & YES & NO & EXPLANATION \\
\hline & & & \\
\hline If yes, how many photos were taken? & \multicolumn{2}{|c|}{2} & \\
\hline If yes, has a photographic log been prepared? & & & Log number: IMG _ $0842, I M G_{-} 0843$ \\
\hline E. FIELD CONCLUSIONS & YES & No & EXPLANATION (required if shaded box is checked) \\
\hline \multicolumn{4}{|l|}{ 1. Are more frequent inspections required? } \\
\hline 2. Are existing maintenance/repair actions satisfactory? & & $\checkmark$ & $\begin{array}{rl}I & U R \text { sign was down that needs to be } \\
\text { rehung }\end{array}$ \\
\hline \multicolumn{4}{|l|}{ 3. Is other maintenance/repair necessary? } \\
\hline \multicolumn{4}{|c|}{$\begin{array}{l}\text { 4. Field conclusions/recommendations: The UR signage is legible and in good condition, } \\
\text { but one (1) UR sign was down and needs to be rehung. }\end{array}$} \\
\hline \multicolumn{4}{|l|}{ F. CERTIFICATION } \\
\hline \multicolumn{4}{|c|}{$\begin{array}{l}\text { I have conducted an inspection of CAS 25-20-01, Lab Drain Dry Well, in accordance with the procedures of the Post-Closure Plan as recorded on this } \\
\text { checklist, attached sheets, field notes, photographs, and photograph logs. }\end{array}$} \\
\hline Chief Inspector's Signature: /s/ G Richardson & & Date: & $12 / 03 / 08$ \\
\hline Printed Name: Glenn Richardson & & Title: & Task Manager \\
\hline
\end{tabular}

Attachment: Maintenance records (check if attached) 


\section{CAU 168: AREA 25 AND 26 CONTAMINATED MATERIALS AND WASTE DUMPS}


THIS PAGE INTENTIONALLY LEFT BLANK 


\begin{tabular}{|c|c|c|c|c|}
\hline \multicolumn{5}{|c|}{ POST-CLOSURE INSPECTION CHECKLIST } \\
\hline \multicolumn{5}{|c|}{$\begin{array}{l}\text { CAU 168: AREA } 25 \text { AND } 26 \text { CONTAMINATED MATERIALS AND WASTE } \\
\text { CAS 25-16-03, MX CONSTRUCTION LANDFILL } \\
\end{array}$} \\
\hline \multirow{2}{*}{\multicolumn{2}{|c|}{ 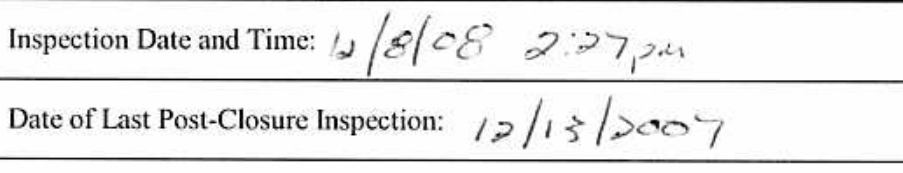 }} & \multicolumn{3}{|c|}{ Reason for Inspection: A, } \\
\hline & & \multicolumn{3}{|c|}{ Reason for Last Post-Closure Inspection: H, Nval } \\
\hline \multicolumn{5}{|c|}{ Responsible Entity: NSTec Environmental Restoration, Nevada Test Site, Mercury, Nevada } \\
\hline \multicolumn{5}{|c|}{ Responsible Facility Owner: Thomas A. Thiele, Project Manager, Industrial Sites, Environmental Restoration Project } \\
\hline \multicolumn{2}{|l|}{ 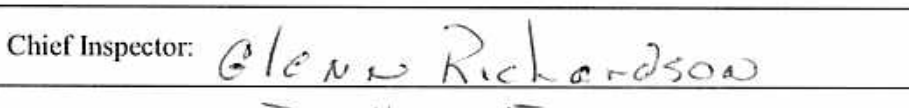 } & \multicolumn{3}{|c|}{ Title: THSK MANayer } \\
\hline \multicolumn{2}{|l|}{ Assistant Inspector: De $21=y$ Emer } & \multicolumn{3}{|c|}{ Title: Sr. Scicotist } \\
\hline \multicolumn{5}{|c|}{$\begin{array}{l}\text { A. GENERAL INSTRUCTIONS } \\
\text { 1. All checklist items must be completed and detailed comments made to document the results of the site inspection. The completed checklist is } \\
\text { part of the field record of the inspection. Additional pages should be used as necessary to ensure that a complete record is made. Attach the } \\
\text { additional pages and number all pages upon completion of the inspection. } \\
\text { 2. Any checklist line item marked by an inspector in a SHADED BOX must be fully explained or an appropriate reference to previous reports } \\
\text { provided. The purpose of this requirement is to provide a written explanation of inspector observations and the inspector's rationale for } \\
\text { conclusions and recommendations. Explanations are to be placed on additional attachments and cross-referenced appropriately. } \\
\text { Explanations, in addition to narrative, will take the form of sketches, measurements, and annotated site maps. } \\
\text { 3. The site inspection is a walking inspection of the entire site including the perimeter and sufficient transects to be able to inspect the entire } \\
\text { surface and all features specifically described in this checklist. } \\
\text { 4. Field notes taken to assist in completion of this checklist will become part of the inspection record. No form is specified for field notes; } \\
\text { however, they must be legible and in sufficient detail to enable review by succeeding inspectors and the responsible agency. } \\
\text { 5. This unit will be inspected annually with formal reporting to the Nevada Division of Environmental Protection to be done annually. The } \\
\text { annual letter report will include a summary with this inspection checklist attached. }\end{array}$} \\
\hline B. PREPARATION (To be competed prior to site visit) & YES & NO & EXPI & ANATION (required if shaded box is checked) \\
\hline \multicolumn{5}{|l|}{ 1. Has the Post-Closure Plan been reviewed? } \\
\hline \multicolumn{5}{|l|}{ 2. Have the previous inspection reports been reviewed? } \\
\hline \multicolumn{5}{|l|}{ 3. Were anomalies or trends detected on previous inspections? } \\
\hline \multicolumn{5}{|l|}{ 4. Were maintenance or repairs performed since last inspection? } \\
\hline $\begin{array}{l}\text { a. If yes, obtain a copy of maintenance records and attach to } \\
\text { checklist. }\end{array}$ & & & NA & \\
\hline $\begin{array}{l}\text { b. If yes (on } 4 \text { ), has site repair resulted in a change from as- } \\
\text { built conditions? }\end{array}$ & & & NA & \\
\hline $\begin{array}{l}\text { c. If yes (to } 4 \mathrm{~b} \text { ), are revised as-built plans available that reflect } \\
\text { repair changes? }\end{array}$ & & & NA & \\
\hline \multicolumn{5}{|l|}{ C. SITE INSPECTION PREPARATION } \\
\hline \multicolumn{5}{|c|}{$\begin{array}{l}\text { Assemble the following, as needed, to conduct inspections: } \\
\text { a. Radio, pager, etc. } \\
\text { b. Previous letter report, inspection checklists, repair records, and as-built plans } \\
\text { c. Other miscellaneous support equipment }\end{array}$} \\
\hline \multicolumn{5}{|l|}{ D. SITE INSPECTION } \\
\hline \multirow{4}{*}{$\begin{array}{l}\text { 1. Site markers: } \\
\text { a. Is there damage to the fence? } \\
\text { b. Have any posts been damaged or their anchoring } \\
\text { weakened? } \\
\text { c. Are any of the } 10 \text { use restriction signs damaged or missing? }\end{array}$} & YES & NO & \multicolumn{2}{|c|}{ EXPLANATION (required if shaded box is checked) } \\
\hline & & $\sim$ & & \\
\hline & & $>$ & & \\
\hline & & 工 & & \\
\hline
\end{tabular}




\begin{tabular}{|c|c|c|c|}
\hline \multicolumn{4}{|c|}{ POST-CLOSURE INSPECTION CHECKLIST } \\
\hline \multicolumn{4}{|c|}{$\begin{array}{l}\text { CAU 168: AREA 25 AND 26 CONTAMINATED MATERIALS AND WASTE } \\
\text { CAS 25-16-03, MX CONSTRUCTION LANDFILL }\end{array}$} \\
\hline 1. Site markers (continued): & YES & NO & EXPLANATION (required if shaded box is checked) \\
\hline d. Are all use restriction signs legible? & L & & \\
\hline e. How many signs need to be replaced? & \multicolumn{2}{|c|}{0} & \\
\hline \multirow{2}{*}{$\begin{array}{l}\text { 2. Use-restricted area: } \\
\text { a. Is there evidence of human intrusion onto the site }\end{array}$} & YES & NO & EXPLANATION (required if shaded box is checked) \\
\hline & & $\sim$ & \\
\hline \multirow{2}{*}{$\begin{array}{l}\text { 3. Photograph Documentation (optional): } \\
\text { a. Have photographs been taken of the site? }\end{array}$} & YES & NO & EXPLANATION \\
\hline & 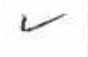 & & \\
\hline \multicolumn{3}{|l|}{ If yes, how many photos were taken? } & \\
\hline If yes, has a photographic log been prepared? & 2 & & Log number: $\mid 0 x)-8(/ 4)$ to $100-84 \%$ \\
\hline E. FIELD CONCLUSIONS & YES & NO & EXPLANATION (required if shaded box is checked) \\
\hline \multicolumn{3}{|l|}{ 1. Are more frequent inspections required? } & \\
\hline \multicolumn{3}{|l|}{ 2. Are existing maintenance/repair actions satisfactory? } & \\
\hline \multicolumn{3}{|l|}{ 3. Is other maintenance/repair necessary? } & \\
\hline \multicolumn{4}{|l|}{ 4. Field conclusions/recommendations: } \\
\hline \multicolumn{4}{|l|}{ F. CERTIFICATION } \\
\hline \multicolumn{4}{|c|}{$\begin{array}{l}\text { I have conducted an inspection of CAS 25-16-03, MX Construction Landfill, in accordance with the procedures of the Post-Closure Plan as recorded on this } \\
\text { checklist, attached sheets, field notes, photographs, and photograph logs. }\end{array}$} \\
\hline \multicolumn{2}{|c|}{ Chief Inspector's Signature: /s/ G Richardson } & & 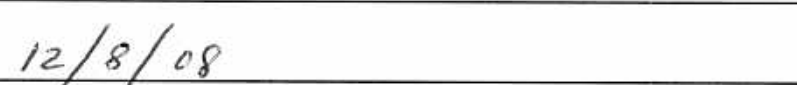 \\
\hline Printed Name: Glen" Fichardson & & Title: & Mauager \\
\hline
\end{tabular}

Attachments (check if attached):

$\square$ Maintenance records 


\begin{tabular}{|c|c|c|}
\hline \multicolumn{3}{|c|}{ POST-CLOSURE INSPECTION CHECKLIST } \\
\hline \multicolumn{3}{|c|}{$\begin{array}{c}\text { CAU 168: AREA 25 AND 26 CONTAMINATED MATERIALS AND WASTE } \\
\text { CAS 25-23-02, RADIOACTIVE STORAGE RR CARS } \\
\end{array}$} \\
\hline \multicolumn{2}{|c|}{ Inspection Date and Time: $12 / 17 / 08 \quad 10: 17 \mathrm{Am}$} & Reason for Inspection: Arwo a \\
\hline \multicolumn{2}{|l|}{ Date of Last Post-Closure Inspection: $121,3 \mid 2007$} & Reason for Last Post-Closure Inspection: $A$ w 0 a \\
\hline \multicolumn{3}{|c|}{ Responsible Entity: NSTec Environmental Restoration, Nevada Test Site, Mercury, Nevada } \\
\hline \multicolumn{3}{|c|}{ Responsible Facility Owner: Thomas A. Thiele, Project Manager, Industrial Sites, Environmental Restoration Project } \\
\hline \multicolumn{2}{|c|}{ 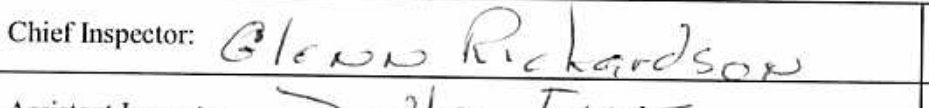 } & Title: Tas of 1 Thager \\
\hline \multicolumn{2}{|l|}{ 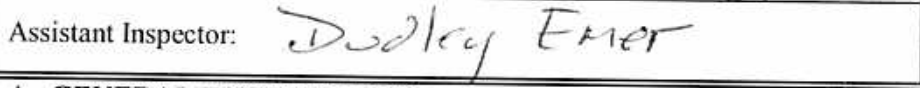 } & Title: Sr Sovertisit \\
\hline \multicolumn{3}{|c|}{$\begin{array}{l}\text { A. GENERAL INSTRUCTIONS } \\
\text { 1. All checklist items must be completed and detailed comments made to document the results of the site inspection. The completed checklist is } \\
\text { part of the field record of the inspection. Additional pages should be used as necessary to ensure that a complete record is made. Attach the } \\
\text { additional pages and number all pages upon completion of the inspection. } \\
\text { 2. Any checklist line item marked by an inspector in a SHADED BOX must be fully explained or an appropriate reference to previous reports } \\
\text { provided. The purpose of this requirement is to provide a written explanation of inspector observations and the inspector's rationale for } \\
\text { conclusions and recommendations. Explanations are to be placed on additional attachments and cross-referenced appropriately. } \\
\text { Explanations, in addition to narrative, will take the form of sketches, measurements, and annotated site maps. } \\
\text { 3. The site inspection is a walking inspection of the entire site including the perimeter and sufficient transects to be able to inspect the entire } \\
\text { surface and all features specifically described in this checklist. } \\
\text { 4. Field notes taken to assist in completion of this checklist will become part of the inspection record. No form is specified for field notes; } \\
\text { however, they must be legible and in sufficient detail to enable review by succeeding inspectors and the responsible agency. } \\
\text { 5. This unit will be inspected annually with formal reporting to the Nevada Division of Environmental Protection to be done annually. The } \\
\text { annual letter report will include a summary with this inspection checklist attached. }\end{array}$} \\
\hline B. PREPARATION (To be competed prior to site visit) & YES NO & EXPLANATION (required if shaded box is checked) \\
\hline \multicolumn{3}{|l|}{ 1. Has the Post-Closure Plan been reviewed? } \\
\hline \multicolumn{3}{|l|}{ 2. Have the previous inspection reports been reviewed? } \\
\hline \multicolumn{3}{|l|}{ 3. Were anomalies or trends detected on previous inspections? } \\
\hline \multirow{2}{*}{$\begin{array}{l}\text { 4. Were maintenance or repairs performed since last inspection? } \\
\text { a. If yes, obtain a copy of maintenance records and attach to } \\
\text { checklist. }\end{array}$} & & 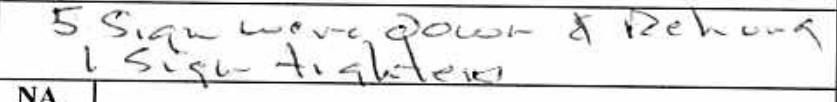 \\
\hline & & the \\
\hline \multicolumn{3}{|l|}{ C. SITE INSPECTION PREPARATION } \\
\hline \multicolumn{3}{|c|}{$\begin{array}{l}\text { Assemble the following, as needed, to conduct inspections: } \\
\text { a. Radio, pager, etc. } \\
\text { b. Previous letter report, inspection checklists, repair records, and as-built plans } \\
\text { c. Other miscellaneous support equipment } \\
\end{array}$} \\
\hline
\end{tabular}

\section{SITE INSPECTION}

1. Site markers:

a. Is there damage to the fence?

b. Have any posts been damaged or their anchoring weakened?

c. Are any of the 6 use restriction signs damaged or missing?

d. Are all use restriction signs legible?

e. How many signs need to be replaced?

\begin{tabular}{|l|l|l|}
\hline YES & NO & EXPLANATION (required if shaded box is checked) \\
\hline & & \\
\hline & 4 & \\
\hline & & \\
\hline & & \\
\hline
\end{tabular}




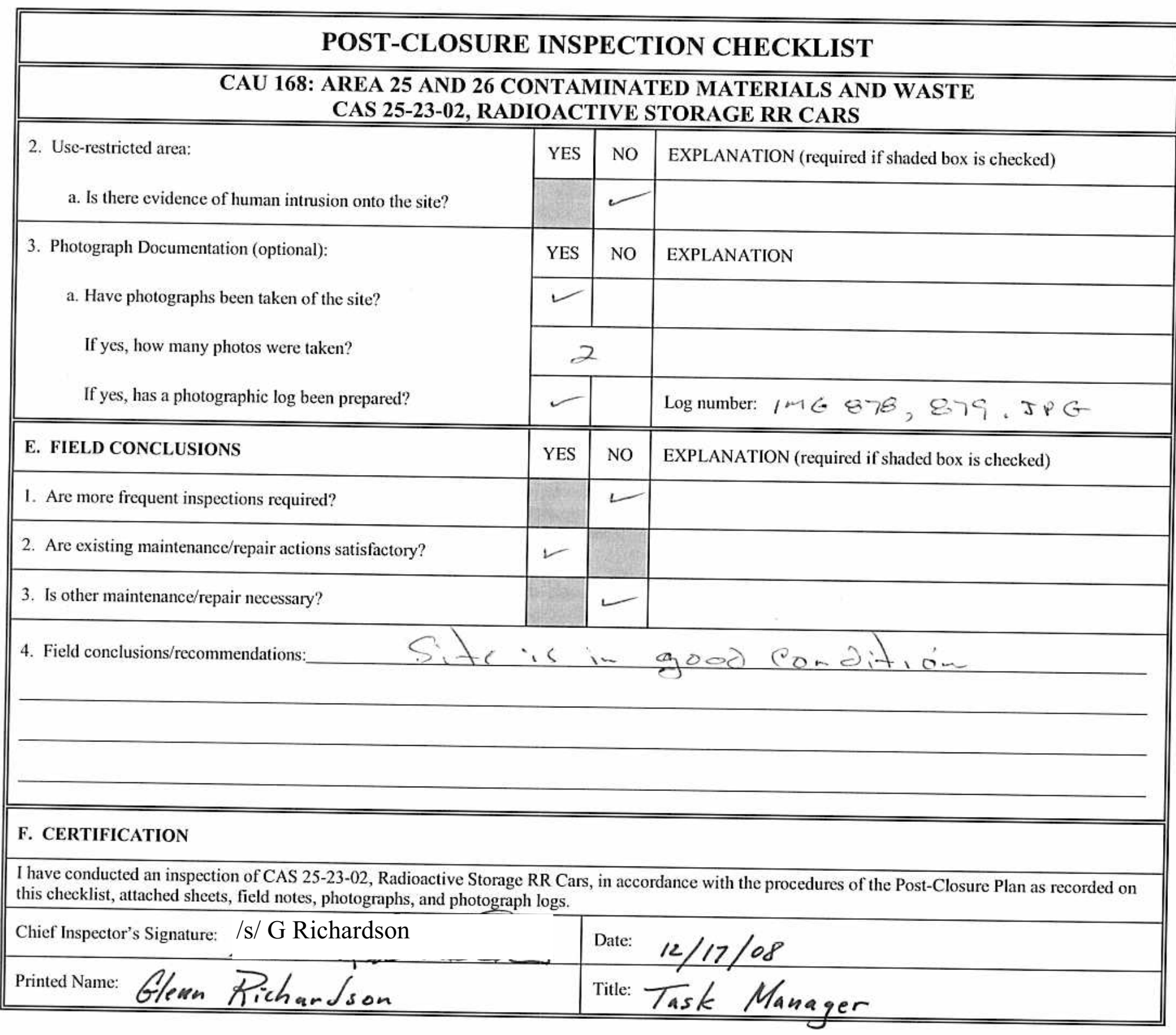

Attachments (check if attached):

$\checkmark$ Maintenance records 


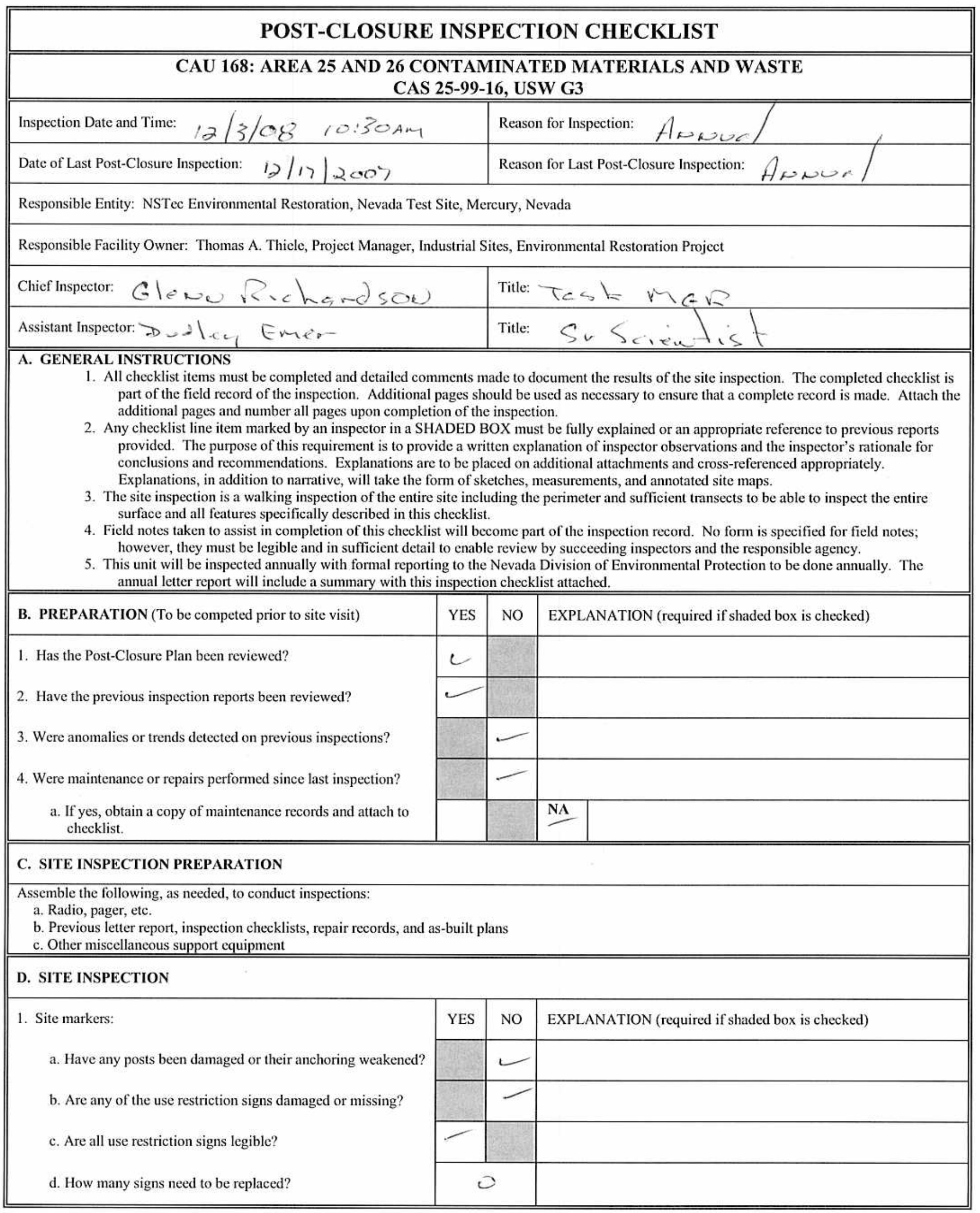




\begin{tabular}{|c|c|c|c|}
\hline \multicolumn{4}{|c|}{ POST-CLOSURE INSPECTION CHECKLIST } \\
\hline \multicolumn{4}{|c|}{$\begin{array}{l}\text { CAU 168: AREA } 25 \text { AND 26 CONTAMINATED MATERIALS AND WASTE } \\
\text { CAS 25-99-16, USW G3 }\end{array}$} \\
\hline \multirow{2}{*}{$\begin{array}{l}\text { 2. Use-restricted area: } \\
\text { a. Is there evidence of human intrusion onto the site? }\end{array}$} & YES & NO & EXPLANATION (required if shaded box is checked) \\
\hline & & & \\
\hline 3. Photograph Documentation (optional): & YES & NO & EXPLANATION \\
\hline \multicolumn{4}{|l|}{ a. Have photographs been taken of the site? } \\
\hline \multicolumn{4}{|l|}{ If yes, how many photos were taken? } \\
\hline If yes, has a photographic log been prepared? & & & 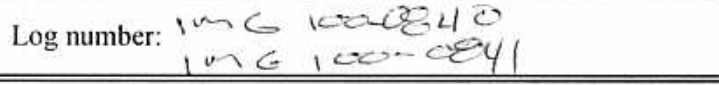 \\
\hline E. FIELD CONCLUSIONS & YES & NO & EXPLANATION (required if shaded box is checked) \\
\hline \multicolumn{4}{|l|}{ 1. Are more frequent inspections required? } \\
\hline \multicolumn{4}{|l|}{ 2. Are existing maintenance/repair actions satisfactory? } \\
\hline \multicolumn{4}{|l|}{ 3. Is other maintenance/repair necessary? } \\
\hline \multicolumn{4}{|c|}{ 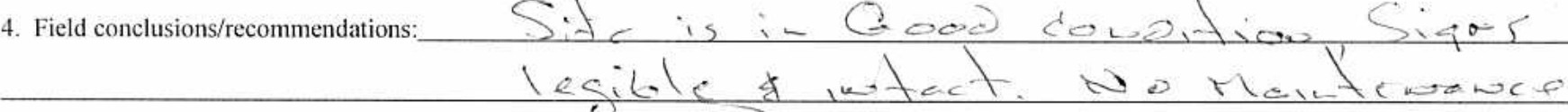 } \\
\hline \multicolumn{4}{|l|}{ F. CERTIFICATION } \\
\hline \multicolumn{4}{|c|}{$\begin{array}{l}\text { I have conducted an inspection of CAS } 25-99-16 \text {, USW G3, in accordance with the procedures of the Post-Closure Plan as recorded on this checklist, } \\
\text { attached sheets, field notes, photographs, and photograph logs. }\end{array}$} \\
\hline \multicolumn{2}{|l|}{ Chief Inspector's Signature: /s/ G Richardson } & Date: & 108 \\
\hline Printed Name: Glenn Ticherdson & & Title: & Task Manager \\
\hline
\end{tabular}

Attachments (check if attached):

Maintenance records 
CAU 204: STORAGE BUNKERS 
THIS PAGE INTENTIONALLY LEFT BLANK 


\section{POST-CLOSURE INSPECTION CHECKLIST}

\section{CAU 204: STORAGE BUNKERS - CAS 01-34-01, UNDERGROUND INST. HOUSE BUNKER}

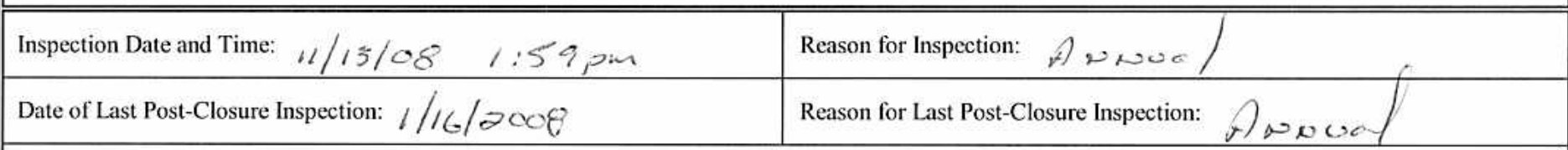

Responsible Entity: NSTec Environmental Restoration, Nevada Test Site, Mercury, Nevada

Responsible Facility Owner: Thomas A. Thiele, Project Manager, Industrial Sites, Environmental Restoration Project

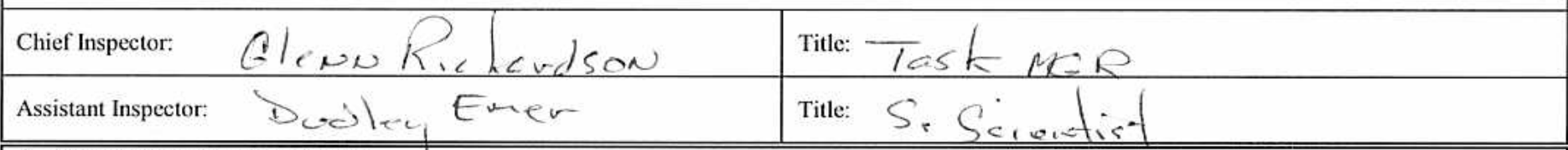

A. GENERAL INSTRUCTIONS

1. All checklist items must be completed and detailed comments made to document the results of the site inspection. The completed checklist is part of the field record of the inspection. Additional pages should be used as necessary to ensure that a complete record is made. Attach the additional pages and number all pages upon completion of the inspection.

2. Any checklist line item marked by an inspector in a SHADED BOX must be fully explained or an appropriate reference to previous reports provided. The purpose of this requirement is to provide a written explanation of inspector observations and the inspector's rationale for conclusions and recommendations. Explanations are to be placed on additional attachments and cross-referenced appropriately. Explanations, in addition to narrative, will take the form of sketches, measurements, and annotated site maps.

3. The site inspection is a walking inspection of the entire site including the perimeter and sufficient transects to be able to inspect the entire surface and all features specifically described in this checklist.

4. Field notes taken to assist in completion of this checklist will become part of the inspection record. No form is specified for field notes; however, they must be legible and in sufficient detail to enable review by succeeding inspectors and the responsible agency.

5. This unit will be inspected annually with formal reporting to the Nevada Division of Environmental Protection to be done annually. The annual letter report will include a summary with this inspection checklist attached.

\begin{tabular}{|c|c|c|c|}
\hline B. PREPARATION (To be competed prior to site visit) & YES & NO & EXPLANATION (required if shaded box is checked) \\
\hline 1. Has the Post-Closure Plan been reviewed? & & & \\
\hline 2. Have the previous inspection reports been reviewed? & & & \\
\hline 3. Were anomalies or trends detected on previous inspections? & & & \\
\hline 4. Were maintenance or repairs performed since last inspection? & & & \\
\hline
\end{tabular}

\section{SITE INSPECTION PREPARATION}

Assemble the following, as needed, to conduct inspections:

a. Radio, pager, etc.

b. Previous letter report, inspection checklists, repair records, and as-built plans

c. Other miscellaneous support equipment

\section{SITE INSPECTION}

1. Site markers:

a. Have any posts been damaged or their anchoring weakened?

b. Are any of the use restriction signs damaged or missing?

c. Are all use restriction signs legible?

d. How many signs need to be replaced?

2. Use-restricted area:

a. Is there evidence of human intrusion onto the site?

\begin{tabular}{|c|c|l||}
\hline YES & NO & EXPLANATION (required if shaded box is checked) \\
\hline & - & \\
\hline & - & \\
\hline & & \\
\hline & 0 & \\
\hline YES & NO & EXPLANATION (required if shaded box is checked) \\
\hline & - & \multicolumn{2}{l}{} \\
\hline
\end{tabular}




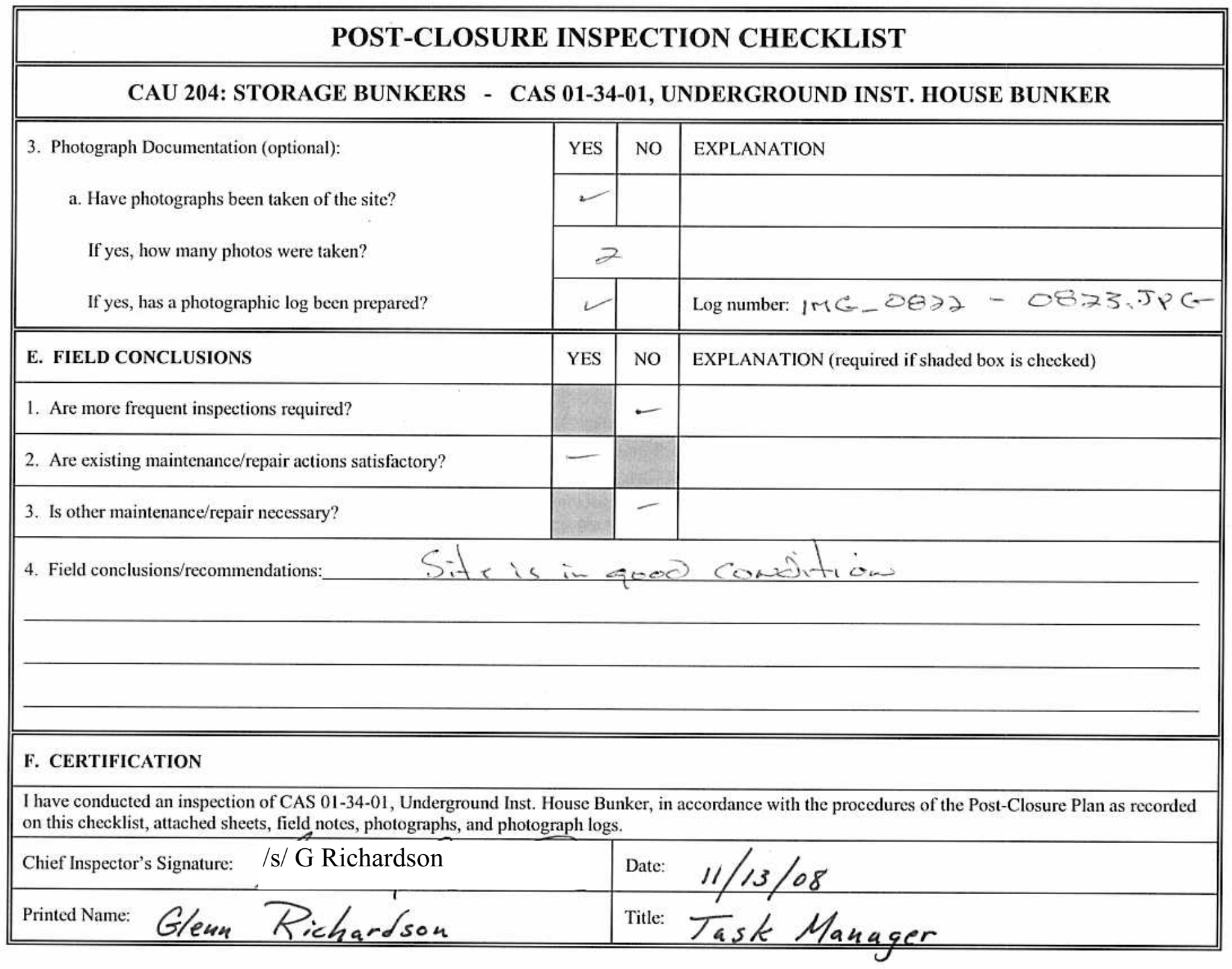




\section{POST-CLOSURE INSPECTION CHECKLIST}

\section{CAU 204: STORAGE BUNKERS - CAS 02-34-01, INSTRUMENT BUNKER}

\begin{tabular}{|c|c|c|}
\hline Inspection Date and Time: $1 / 13$ & $1: 12$, & Reason for Inspection: $A$, \\
\hline Date of Last Post-Closure Inspection: & $1 / 1610$ & Reason for Last Post-Closure Inspection: A, NN \\
\hline
\end{tabular}

Responsible Entity: NSTec Environmental Restoration, Nevada Test Site, Mercury, Nevada

Responsible Facility Owner: Thomas A. Thiele, Project Manager, Industrial Sites, Environmental Restoration Project

Assistant Inspector: Dod

A. GENERAL INSTRUCTIONS

1. All checklist items must be completed and detailed comments made to document the results of the site inspection. The completed checklist is part of the field record of the inspection. Additional pages should be used as necessary to ensure that a complete record is made. Attach the additional pages and number all pages upon completion of the inspection.

2. Any checklist line item marked by an inspector in a SHADED BOX must be fully explained or an appropriate reference to previous reports provided. The purpose of this requirement is to provide a written explanation of inspector observations and the inspector's rationale for conclusions and recommendations. Explanations are to be placed on additional attachments and cross-referenced appropriately. Explanations, in addition to narrative, will take the form of sketches, measurements, and annotated site maps.

3. The site inspection is a walking inspection of the entire site including the perimeter and sufficient transects to be able to inspect the entire surface and all features specifically described in this checklist.

4. Field notes taken to assist in completion of this checklist will become part of the inspection record. No form is specified for field notes; however, they must be legible and in sufficient detail to enable review by succeeding inspectors and the responsible agency.

5. This unit will be inspected annually with formal reporting to the Nevada Division of Environmental Protection to be done annually. The annual letter report will include a summary with this inspection checklist attached.

B. PREPARATION (To be competed prior to site visit)

1. Has the Post-Closure Plan been reviewed?

2. Have the previous inspection reports been reviewed?

3. Were anomalies or trends detected on previous inspections?

4. Were maintenance or repairs performed since last inspection?

\section{SITE INSPECTION PREPARATION}

Assemble the following, as needed, to conduct inspections:

a. Radio, pager, etc.

b. Previous letter report, inspection checklists, repair records, and as-built plans

c. Other miscellaneous support equipment

\section{SITE INSPECTION}

1. Site markers:

a. Have any posts been damaged or their anchoring weakened?

b. Are any of the use restriction signs damaged or missing?

c. Are all use restriction signs legible?

d. How many signs need to be replaced?

2. Use-restricted area:

a. Is there evidence of human intrusion onto the site?

\begin{tabular}{|l|l|l|}
\hline YES & NO & EXPLANATION (required if shaded box is checked) \\
\hline & & \\
\hline & & \\
\hline & & \\
\hline
\end{tabular}




\section{POST-CLOSURE INSPECTION CHECKLIST}

\section{CAU 204: STORAGE BUNKERS - CAS 02-34-01, INSTRUMENT BUNKER}

3. Photograph Documentation (optional):

a. Have photographs been taken of the site?

If yes, how many photos were taken?

If yes, has a photographic log been prepared?

\begin{tabular}{|c|c|c|}
\hline YES & NO & EXPLANATION \\
\hline & & \\
\hline$\sim$ & & Log number:Im C OS।E-OEDO.JPG \\
\hline
\end{tabular}

\begin{tabular}{|l|l|l|l|}
\hline E. FIELD CONCLUSIONS & YES & NO & EXPLANATION (required if shaded box is checked) \\
\hline 1. Are more frequent inspections required? & & E & \\
\hline 2. Are existing maintenance/repair actions satisfactory? & & & Reilce T Posts st Siqu \\
\hline 3. Is other maintenance/repair necessary? & & \\
\hline
\end{tabular}

4. Field conclusions/recommendations: $T$ Posts at $\mathrm{Si}$

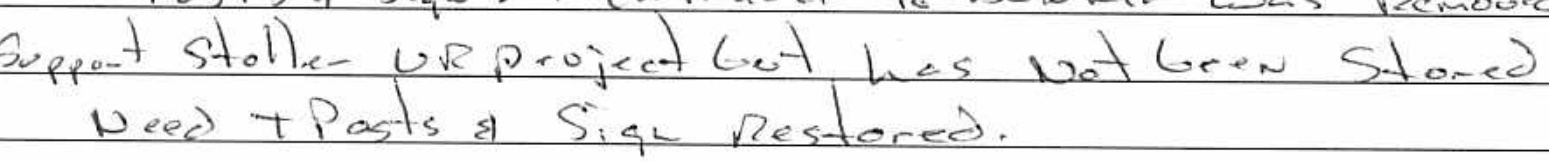

\section{F. CERTIFICATION}

I have conducted an inspection of CAS 02-34-01, Instrument Bunker, in accordance with the procedures of the Post-Closure Plan as recorded on this checklist, attached sheets, field notes, photographs, and photograph logs.

Chief Inspector's Signature: /s/ G Richardson

Printed Name: Gleun Kichardson

\section{Date: $11 / 13 / 08$}

Title: Task Manager 


\section{POST-CLOSURE INSPECTION CHECKLIST}

\section{CAU 204: STORAGE BUNKERS - CAS 03-34-01, UNDERGROUND BUNKER}

\begin{tabular}{|l|l|}
\hline \hline Inspection Date and Time: $11 / 4 / 08 \quad 14:>2$ & Reason for Inspection: \\
\hline Date of Last Post-Closure Inspection: $1 / 16 / 08$ & Reason for Last Post-Closure Inspection: \\
\hline
\end{tabular}

Responsible Entity: NSTec Environmental Restoration, Nevada Test Site, Mercury, Nevada

Responsible Facility Owner: Thomas A. Thiele, Project Manager, Industrial Sites, Environmental Restoration Project

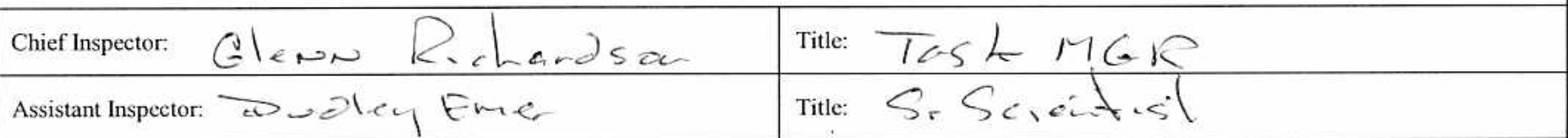

\section{A. GENERAL INSTRUCTIONS}

1. All checklist items must be completed and detailed comments made to document the results of the site inspection. The completed checklist is part of the field record of the inspection. Additional pages should be used as necessary to ensure that a complete record is made. Attach the additional pages and number all pages upon completion of the inspection.

2. Any checklist line item marked by an inspector in a SHADED BOX must be fully explained or an appropriate reference to previous reports provided. The purpose of this requirement is to provide a written explanation of inspector observations and the inspector's rationale for conclusions and recommendations. Explanations are to be placed on additional attachments and cross-referenced appropriately. Explanations, in addition to narrative, will take the form of sketches, measurements, and annotated site maps.

3. The site inspection is a walking inspection of the entire site including the perimeter and sufficient transects to be able to inspect the entire surface and all features specifically described in this checklist.

4. Field notes taken to assist in completion of this checklist will become part of the inspection record. No form is specified for field notes; however, they must be legible and in sufficient detail to enable review by succeeding inspectors and the responsible agency.

5. This unit will be inspected annually with formal reporting to the Nevada Division of Environmental Protection to be done annually. The annual letter report will include a summary with this inspection checklist attached.

B. PREPARATION (To be competed prior to site visit)

1. Has the Post-Closure Plan been reviewed?

2. Have the previous inspection reports been reviewed?

3. Were anomalies or trends detected on previous inspections?

4. Were maintenance or repairs performed since last inspection?

\section{SITE INSPECTION PREPARATION}

Assemble the following, as needed, to conduct inspections:

a. Radio, pager, etc.

b. Previous letter report, inspection checklists, repair records, and as-built plans

c. Other miscellaneous support equipment

\section{SITE INSPECTION}

1. Site markers:

a. Have any posts been damaged or their anchoring weakened?

b. Are any of the use restriction signs damaged or missing?

c. Are all use restriction signs legible?

d. How many signs need to be replaced?

2. Use-restricted area:

a. Is there evidence of human intrusion onto the site?

\begin{tabular}{|r|l|l||}
\hline YES & NO & EXPLANATION (required if shaded box is checked) \\
\hline & & \\
\hline & & \\
\hline & & \\
\hline YES & NO & EXPLANATION (required if shaded box is checked) \\
\hline & & \\
\hline
\end{tabular}




\section{POST-CLOSURE INSPECTION CHECKLIST}

\section{CAU 204: STORAGE BUNKERS - CAS 03-34-01, UNDERGROUND BUNKER}

3. Photograph Documentation (optional):

a. Have photographs been taken of the site?

If yes, how many photos were taken?

If yes, has a photographic $\log$ been prepared?

\begin{tabular}{|c|c|c|}
\hline YES & NO & EXPLANATION \\
\hline- & & \\
\hline$r$ & & Log number: IMG $\operatorname{ImG-0796.JPG-}$ \\
\hline
\end{tabular}

\begin{tabular}{|c|c|c|c|}
\hline E. FIELD CONCLUSIONS & YES & NO & EXPLANATION (required if shaded box is checked) \\
\hline 1. Are more frequent inspections required & & 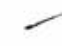 & \\
\hline 2. Are existing maintenance/repair actions & & & \\
\hline 3. Is other maintenance/repair necessary? & & - & \\
\hline
\end{tabular}

conclusions/recommendations:

\section{F. CERTIFICATION}

I have conducted an inspection of CAS 03-34-01, Underground Bunker, in accordance with the procedures of the Post-Closure Plan as recorded on this checklist, attached sheets, field notes, photographs, and photograph logs.

\begin{tabular}{l|l|} 
Chief Inspector's Signature: /s/G Richardson & Date: $11 / 04 / 08$ \\
\hline Printed Name: Glenn Tichardson & Title: Task Manager \\
\hline
\end{tabular}




\section{POST-CLOSURE INSPECTION CHECKLIST}

\section{CAU 204: STORAGE BUNKERS - CAS 05-18-02, CHEMICAL EXPLOSIVES STORAGE}

\begin{tabular}{|c|c|}
\hline Inspection Date and Time: $11 / 1.5 / 059: 380.0$ & Reason for Inspection: Arwo \\
\hline Date of Last Post-Closure Inspection: $\quad 12|1\rangle|0\rangle$ & Reason for Last Post-Closure Inspection: A,, $00 \mathrm{a}$ \\
\hline
\end{tabular}

Responsible Entity: NSTec Environmental Restoration, Nevada Test Site, Mercury, Nevada

Responsible Facility Owner: Thomas A. Thiele, Project Manager, Industrial Sites, Environmental Restoration Project

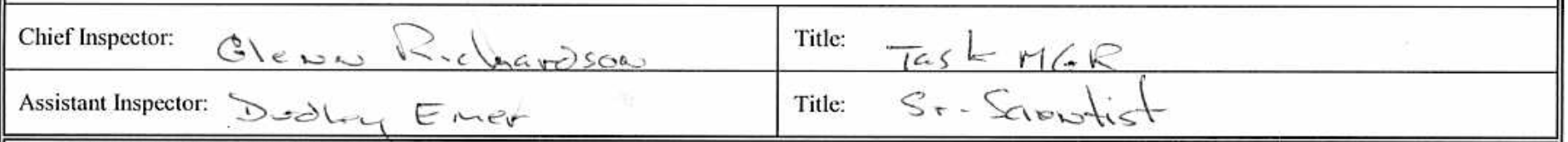

A. GENERAL INSTRUCTIONS

1. All checklist items must be completed and detailed comments made to document the results of the site inspection. The completed checklist is part of the field record of the inspection. Additional pages should be used as necessary to ensure that a complete record is made. Attach the additional pages and number all pages upon completion of the inspection.

2. Any checklist line item marked by an inspector in a SHADED BOX must be fully explained or an appropriate reference to previous reports provided. The purpose of this requirement is to provide a written explanation of inspector observations and the inspector's rationale for conclusions and recommendations. Explanations are to be placed on additional attachments and cross-referenced appropriately. Explanations, in addition to narrative, will take the form of sketches, measurements, and annotated site maps.

3. The site inspection is a walking inspection of the entire site including the perimeter and sufficient transects to be able to inspect the entire surface and all features specifically described in this checklist.

4. Field notes taken to assist in completion of this checklist will become part of the inspection record. No form is specified for field notes; however, they must be legible and in sufficient detail to enable review by succeeding inspectors and the responsible agency.

5. This unit will be inspected annually with formal reporting to the Nevada Division of Environmental Protection to be done annually. The annual letter report will include a summary with this inspection checklist attached.

B. PREPARATION (To be competed prior to site visit)

1. Has the Post-Closure Plan been reviewed?

2. Have the previous inspection reports been reviewed?

3. Were anomalies or trends detected on previous inspections?

4. Were maintenance or repairs performed since last inspection?

\begin{tabular}{|l|l|l||}
\hline YES & NO & EXPLANATION (required if shaded box is checked) \\
\hline & & \\
\hline & - & \\
\hline & - & \\
\hline
\end{tabular}

\section{SITE INSPECTION PREPARATION}

Assemble the following, as needed, to conduct inspections:

a. Radio, pager, etc,

b. Previous letter report, inspection checklists, repair records, and as-built plans

c. Other miscellaneous support equipment

\section{SITE INSPECTION}

1. Site markers:

a. Is there damage to the fence?

b. Have any posts been damaged or their anchoring weakened?

c. Are any of the 13 use restriction signs damaged or missing?

d. Are all use restriction signs legible?

e. How many use restriction signs need to be replaced?

f. Are any of the RMA signs damaged or missing?

\begin{tabular}{|c|c|l||}
\hline YES & NO & EXPLANATION (required if shaded box is checked) \\
\hline & - & \\
\hline & - & \\
\hline & - & \\
\hline$>$ & & \\
\hline \multicolumn{2}{|c|}{} \\
\hline
\end{tabular}




\section{POST-CLOSURE INSPECTION CHECKLIST}

\section{CAU 204: STORAGE BUNKERS - CAS 05-18-02, CHEMICAL EXPLOSIVES STORAGE}

\begin{tabular}{|c|c|c|c|}
\hline 1. Site markers (continued): & YES & NO & EXPLANATION (required if shaded box is checked) \\
\hline g. Are all RMA signs legible? & & & \\
\hline h. How many RMA signs need to be replaced? & \multicolumn{2}{|c|}{0} & \\
\hline \multirow{2}{*}{$\begin{array}{l}\text { 2. Use-restricted area: } \\
\text { a. Is there evidence of human intrusion onto the site? }\end{array}$} & YES & NO & EXPLANATION (required if shaded box is checked) \\
\hline & & & \\
\hline \multirow[t]{2}{*}{ 3. Photograph Documentation (optional): } & YES & NO & EXPLANATION \\
\hline & & & \\
\hline If yes, how many photos were taken? & \multicolumn{2}{|c|}{2} & \\
\hline If yes, has a photographic log been prepared? & & & Log number:imG - \\
\hline E. FIELD CONCLUSIONS & YES & NO & EXPLANATION (required if shaded box is checked) \\
\hline 1. Are more frequent inspections required? & & - & \\
\hline 2. Are existing maintenance/repair actions satisfactory? & - & & \\
\hline 3. Is other maintenance/repair necessary? & & - & \\
\hline
\end{tabular}

\section{F. CERTIFICATION}

I have conducted an inspection of CAS 05-18-02, Chemical Explosives Storage, in accordance with the procedures of the Post-Closure Plan as recorded on this checklist, attached sheets, field notes, photographs, and phetegraph Dogs.

\begin{tabular}{|c|c|}
\hline Chief Inspector's Signature: /s/ G Richardson & Date: $\quad 11 / 13 / 08$ \\
\hline Printed Name: Gean Gichardson & Title: $\frac{}{/ a}$ \\
\hline
\end{tabular}




\section{POST-CLOSURE INSPECTION CHECKLIST}

\section{CAU 204: STORAGE BUNKERS - CAS 05-33-01, KAY BLOCKHOUSE}

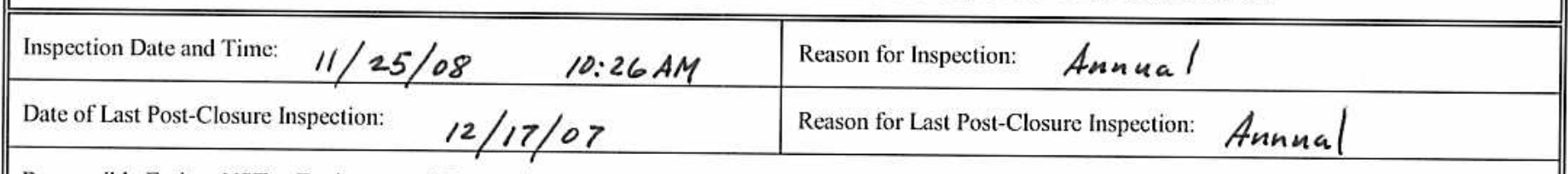

Responsible Entity: NSTec Environmental Restoration, Nevada Test Site, Mercury, Nevada

Responsible Facility Owner: Thomas A. Thiele, Project Manager, Industrial Sites, Environmental Restoration Project

\begin{tabular}{l|l} 
Chief Inspector: Gleun Richardson & Title: Task Manager \\
\hline Assistant Inspector: Chris MeGowin & Title: Field Technical Lead
\end{tabular}

\section{A. GENERAL INSTRUCTIONS}

1. All checklist items must be completed and detailed comments made to document the results of the site inspection. The completed checklist is part of the field record of the inspection. Additional pages should be used as necessary to ensure that a complete record is made. Attach the additional pages and number all pages upon completion of the inspection.

2. Any checklist line item marked by an inspector in a SHADED BOX must be fully explained or an appropriate reference to previous reports provided. The purpose of this requirement is to provide a written explanation of inspector observations and the inspector's rationale for conclusions and recommendations. Explanations are to be placed on additional attachments and cross-referenced appropriately. Explanations, in addition to narrative, will take the form of sketches, measurements, and annotated site maps.

3. The site inspection is a walking inspection of the entire site including the perimeter and sufficient transects to be able to inspect the entire surface and all features specifically described in this checklist.

4. Field notes taken to assist in completion of this checklist will become part of the inspection record. No form is specified for field notes; however, they must be legible and in sufficient detail to enable review by succeeding inspectors and the responsible agency.

5. This unit will be inspected annually with formal reporting to the Nevada Division of Environmental Protection to be done annually. The annual letter report will include a summary with this inspection checklist attached.

B. PREPARATION (To be competed prior to site visit)

1. Has the Post-Closure Plan been reviewed?

2. Have the previous inspection reports been reviewed?

3. Were anomalies or trends detected on previous inspections?

4. Were maintenance or repairs performed since last inspection?

\section{SITE INSPECTION PREPARATION}

Assemble the following, as needed, to conduct inspections:
a. Radio, pager, etc.
b. Previous letter report, inspection checklists, repair records, and as-built plans
c. Other miscellaneous support equipment

\section{SITE INSPECTION}

1. Site markers:

a. Is there damage to the fence?

b. Have any posts been damaged or their anchoring weakened?

c. Are any of the 11 use restriction signs damaged or missing?

d. Are all use restriction signs legible?

e. How many use restriction signs need to be replaced?

f. Are any of the RMA signs damaged or missing?

\begin{tabular}{|l|l|l||}
\hline YES & NO & EXPLANATION (required if shaded box is checked) \\
\hline & & \\
\hline & & \\
\hline & & \\
\hline
\end{tabular}




\section{POST-CLOSURE INSPECTION CHECKLIST}

\section{CAU 204: STORAGE BUNKERS - CAS 05-33-01, KAY BLOCKHOUSE}

1. Site markers (continued):

g. Are all RMA signs legible?

h. How many RMA signs need to be replaced?

2. Use-restricted area:

a. Is there evidence of human intrusion onto the site?

3. Photograph Documentation (optional):

a. Have photographs been taken of the site?

If yes, how many photos were taken?

If yes, has a photographic log been prepared?

\section{E. FIELD CONCLUSIONS}

1. Are more frequent inspections required?

2. Are existing maintenance/repair actions satisfactory?

3. Is other maintenance/repair necessary?

\begin{tabular}{|c|c|c|}
\hline YES & NO & EXPLANATION (required if shaded box is checked) \\
\hline \multicolumn{2}{|c|}{0} & \\
\hline YES & NO & EXPLANATION (required if shaded box is checked) \\
\hline YES & NO & EXPLANATION \\
\hline & & \\
\hline & & Log number: IMG_ $0144-I M G_{-} 0147$ \\
\hline YES & NO & EXPLANATION (required if shaded box is checked) \\
\hline & $V$ & \\
\hline & & \\
\hline & & \\
\hline
\end{tabular}

4. Field conclusions/recommendations: The UR signs, $R M A$ signage, and wire ropefencing are in excellent condition. There are no issues or follow-up actions at this site.

\section{F. CERTIFICATION}

I have conducted an inspection of CAS 05-33-01, Kay Blockhouse, in accordance with the procedures of the Post-Closure Plan as recorded on this checklist, attached sheets, field notes, photographs, and photograph logs.

Chief Inspector's Signature: / $/ \hat{\mathrm{s}}$ G Richardson Printed Name: Glenn Richardson

$11 / 25 / 108$

Title: Task Manager 
CAU 254: AREA 25 R-MAD DECONTAMINATION FACILITY 
THIS PAGE INTENTIONALLY LEFT BLANK 


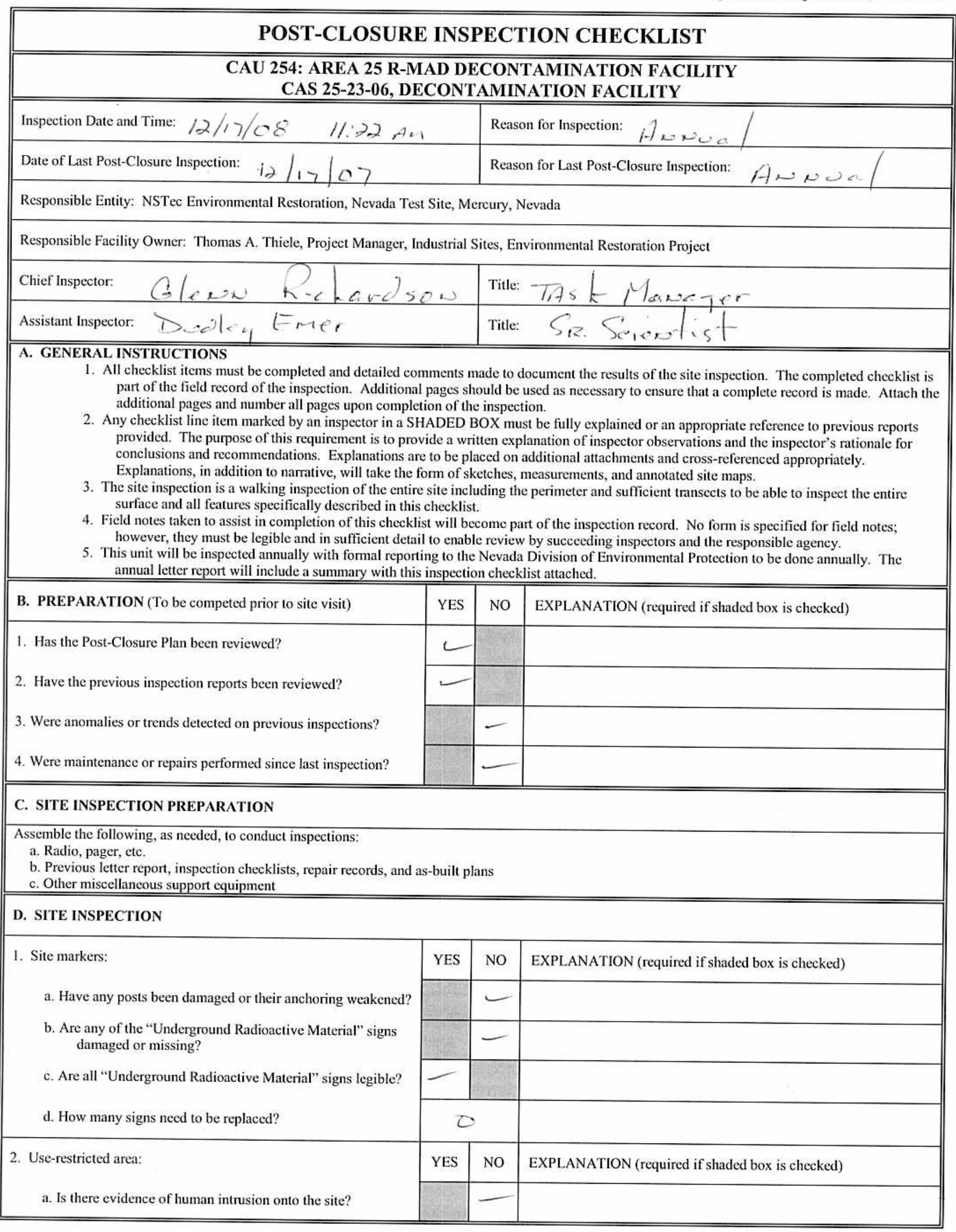




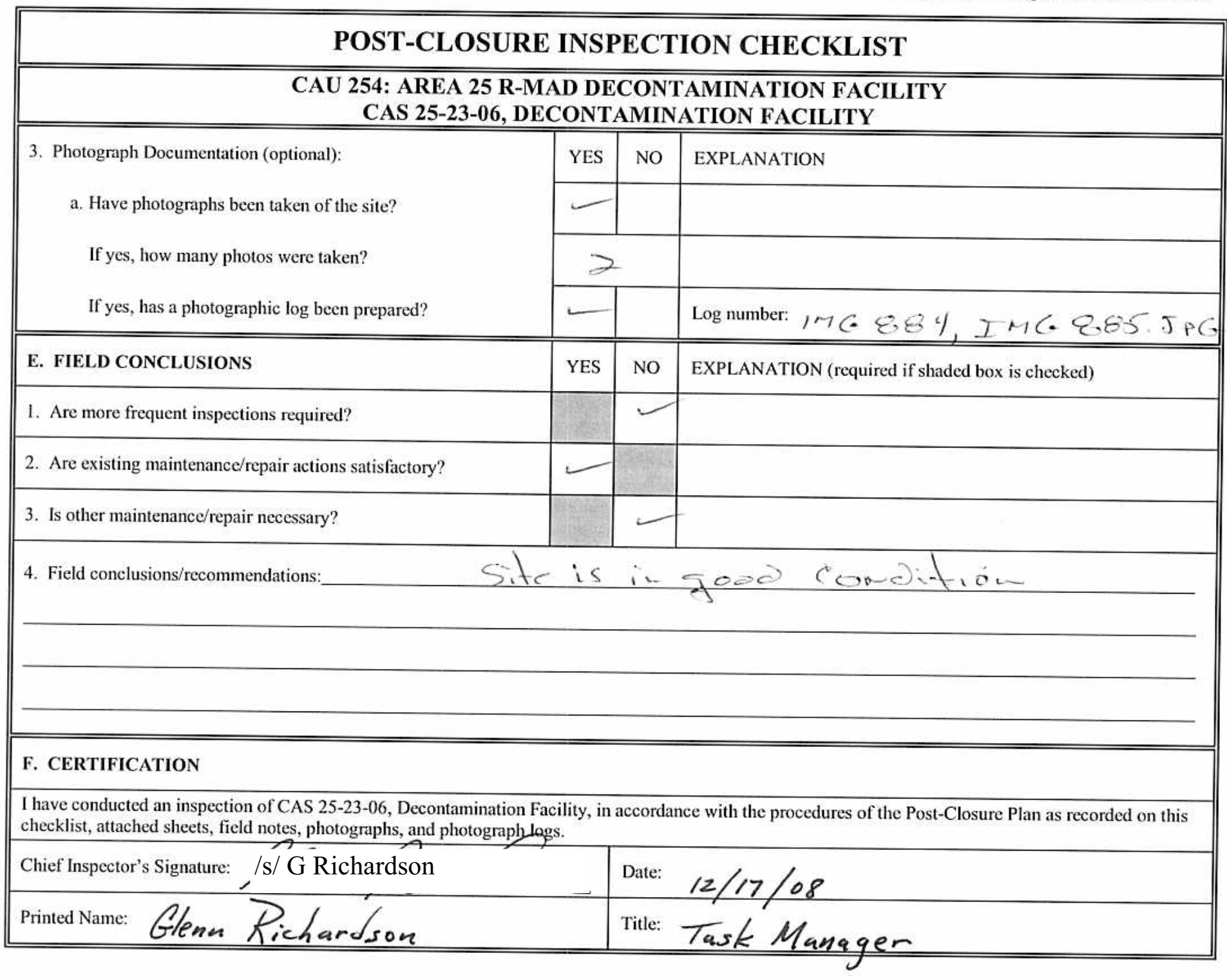


CAU 261: AREA 25 TEST CELL A LEACHFIELD SYSTEM 
THIS PAGE INTENTIONALLY LEFT BLANK 


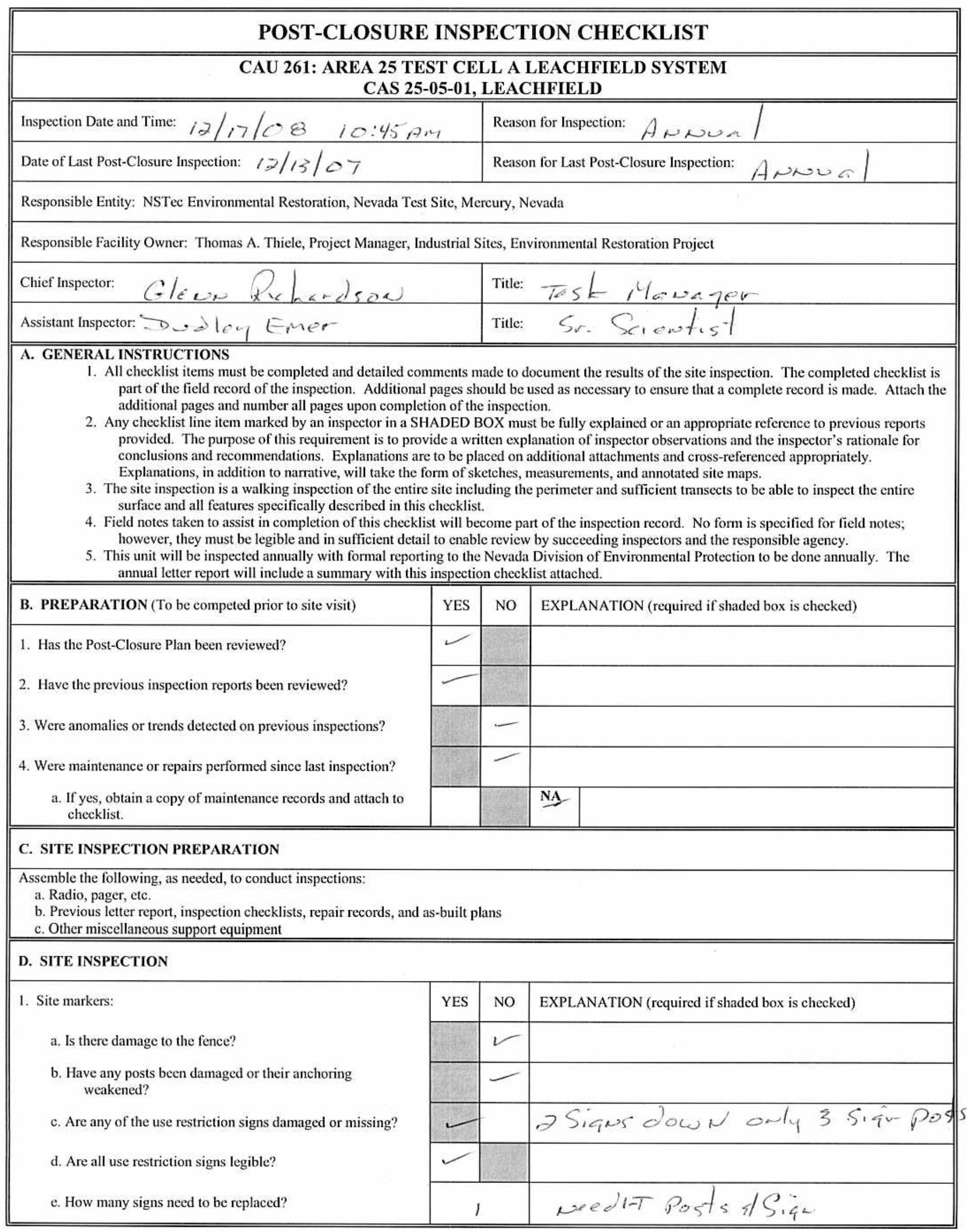




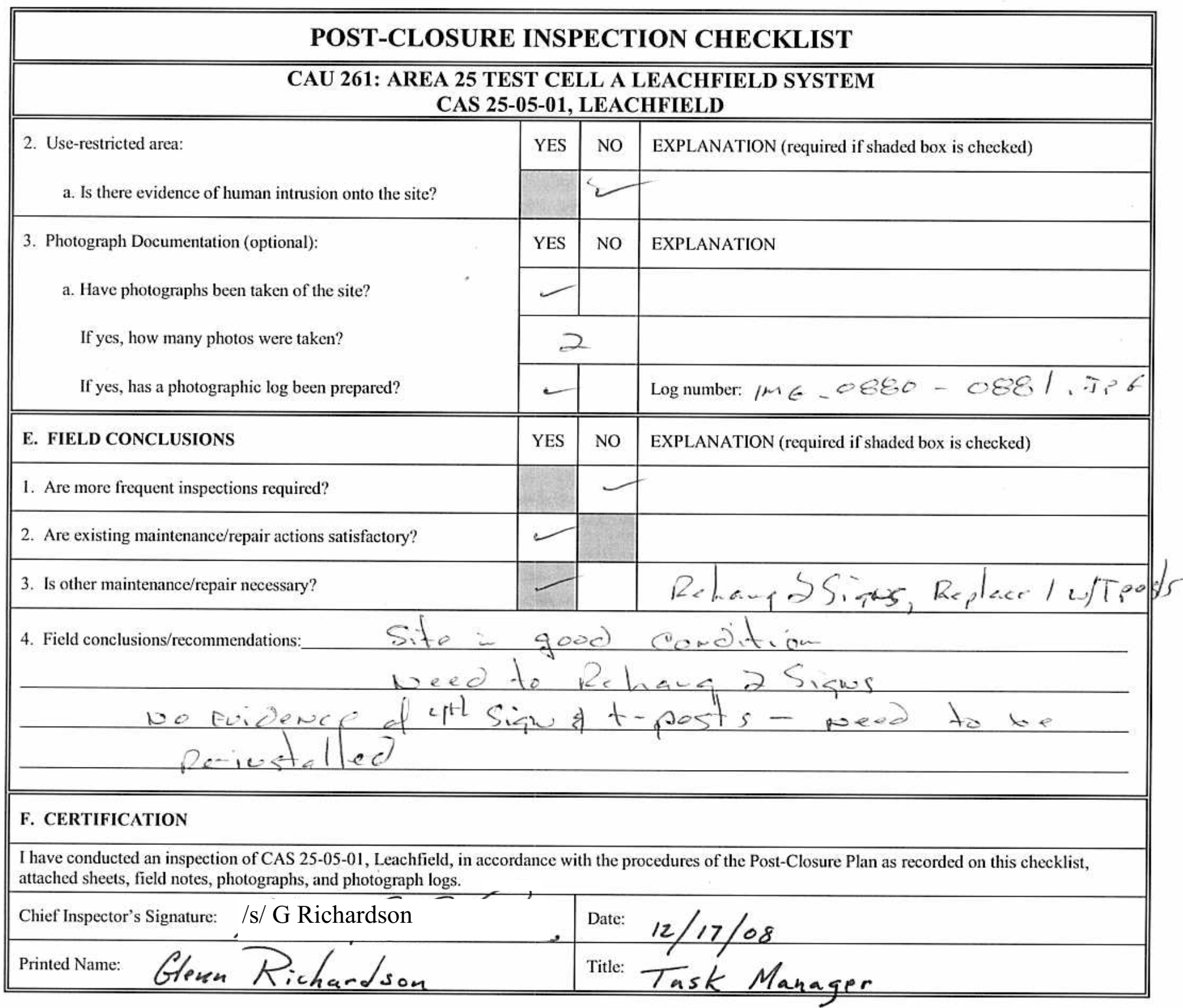

Attachments (check if attached):

$\square$ Maintenance records 
CAU 262: AREA 25 SEPTIC SYSTEMS AND UDP 
THIS PAGE INTENTIONALLY LEFT BLANK 


\begin{tabular}{|c|c|c|c|}
\hline \multicolumn{4}{|c|}{ POST-CLOSURE INSPECTION CHECKLIST } \\
\hline \multicolumn{4}{|c|}{$\begin{array}{l}\text { CAU 262: AREA } 25 \text { SEPTIC SYSTEMS AND UDP } \\
\text { CAS 25-02-06, UNDERGROUND STORAGE TANK }\end{array}$} \\
\hline \multicolumn{2}{|l|}{ Inspection Date and Time: $12 / 3 / 08 \quad 3: 12$ pin } & \multicolumn{2}{|c|}{ Reason for Inspection: A, Nual } \\
\hline \multicolumn{2}{|l|}{ Date of Last Post-Closure Inspection: $\quad 1>/, 3 / \sigma\rangle$} & \multicolumn{2}{|r|}{ Reason for Last Post-Closure Inspection: } \\
\hline \multicolumn{4}{|c|}{ Responsible Entity: NSTec Environmental Restoration, Nevada Test Site, Mercury, Nevada } \\
\hline \multicolumn{4}{|c|}{ Responsible Facility Owner: Thomas A. Thiele, Project Manager, Industrial Sites, Environmental Restoration Project } \\
\hline \multicolumn{2}{|c|}{ 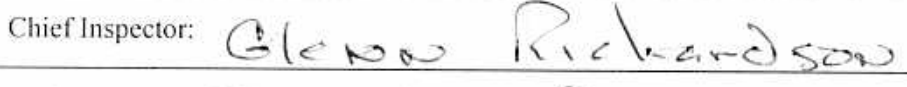 } & \multicolumn{2}{|c|}{ Title: $T<s \mid=r$ rawajer } \\
\hline \multicolumn{2}{|c|}{ Assistant Inspector: $\rightarrow-, C_{4}$ E } & \multicolumn{2}{|c|}{ Title: Sor. Skisitist } \\
\hline \multicolumn{4}{|c|}{$\begin{array}{l}\text { A. GENERAL INSTRUCTIONS } \\
\text { 1. All checklist items must be completed and detailed comments made to document the results of the site inspection. The completed checklist is } \\
\text { part of the field record of the inspection. Additional pages should be used as necessary to ensure that a complete record is made. Attach the } \\
\text { additional pages and number all pages upon completion of the inspection. } \\
\text { 2. Any checklist line item marked by an inspector in a SHADED BOX must be fully explained or an appropriate reference to previous reports } \\
\text { provided. The purpose of this requirement is to provide a written explanation of inspector observations and the inspector's rationale for } \\
\text { conclusions and recommendations. Explanations are to be placed on additional attachments and cross-referenced appropriately. } \\
\text { Explanations, in addition to narrative, will take the form of sketches, measurements, and annotated site maps. } \\
\text { 3. The site inspection is a walking inspection of the entire site including the perimeter and sufficient transects to be able to inspect the entire } \\
\text { surface and all features specifically described in this checklist. } \\
\text { 4. Field notes taken to assist in completion of this checklist will become part of the inspection record. No form is specified for field notes; } \\
\text { however, they must be legible and in sufficient detail to enable review by suceeding inspectors and the responsible agency. } \\
\text { 5. This unit will be inspected annually with formal reporting to the Nevada Division of Environmental Protection to be done annually. The } \\
\text { annual letter report will include a summary with this inspection checklist attached. }\end{array}$} \\
\hline B. PREPARATION (To be competed prior to site visit) & YES & NO & EXPLANATION (required if shaded box is checked) \\
\hline \multicolumn{4}{|l|}{ 1. Has the Post-Closure Plan been reviewed? } \\
\hline \\
\hline \multicolumn{4}{|l|}{ 3. Were anomalies or trends detected on previous inspections? } \\
\hline 4. Were maintenance or repairs performed since last inspection? & & & ISigh was down-Reparined I/Cr \\
\hline \multicolumn{4}{|c|}{ C. SITE INSPECTION PREPARATION } \\
\hline \multicolumn{4}{|c|}{$\begin{array}{l}\text { Assemble the following, as needed, to conduct inspections: } \\
\text { a. Radio, pager, etc. } \\
\text { b. Previous letter report, inspection checklists, repair records, and as-built plans } \\
\text { c. Other miscellaneous support equipment } \\
\end{array}$} \\
\hline \multicolumn{4}{|l|}{ D. SITE INSPECTION } \\
\hline \multirow{2}{*}{$\begin{array}{l}\text { 1. Site markers: } \\
\text { a. Have any posts been damaged or their anchoring weakened: }\end{array}$} & YES & NO & EXPLANATION (required if shaded box is checked) \\
\hline & & & \\
\hline \multicolumn{4}{|l|}{ b. Is either of the 2 use restriction signs damaged or missing? } \\
\hline \multicolumn{4}{|l|}{ c. Are all use restriction signs legible? } \\
\hline d. How many signs need to be replaced? & & & \\
\hline 2. Use-restricted area: & YES & NO & EXPLANATION (required if shaded box is checked) \\
\hline a. Is there evidence of human intrusion onto the site? & & & \\
\hline
\end{tabular}




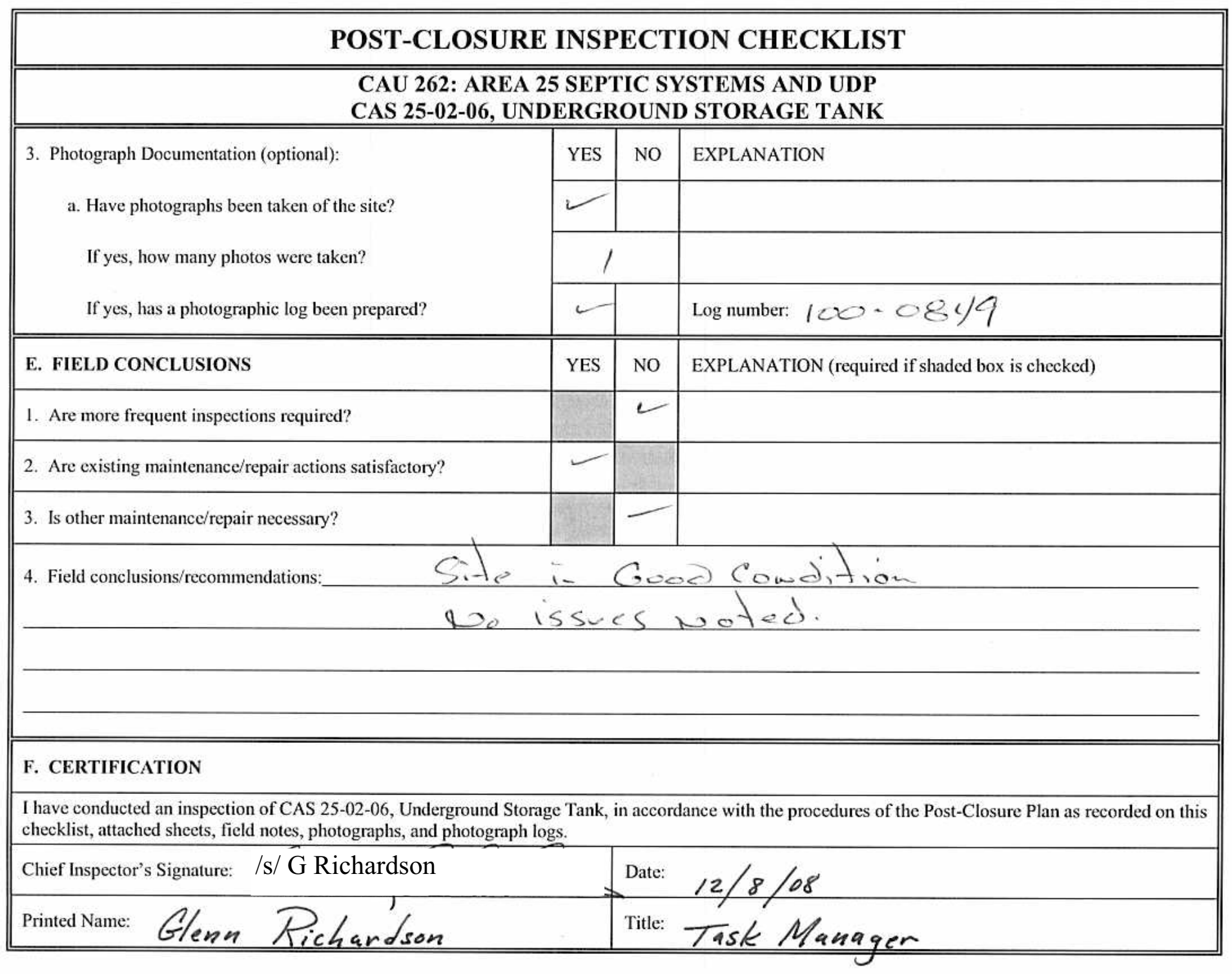




\section{POST-CLOSURE INSPECTION CHECKLIST \\ CAU 262: AREA 25 SEPTIC SYSTEMS AND UDP \\ CAS 25-05-03, LEACHFIELD}

\begin{tabular}{|l|l|}
\hline \hline Inspection Date and Time: $12 / 10108 \quad 16: 12 \mathrm{Am}$ & Reason for Inspection: Ann ua $/ \mathrm{Aeason} \mathrm{for} \mathrm{Last} \mathrm{Post-Closure} \mathrm{Inspection:} \mathrm{Annua/}$ \\
\hline Date of Last Post-Closure Inspection: $12 / 13 / 07$ & R
\end{tabular}

Responsible Entity: NSTec Environmental Restoration, Nevada Test Site, Mercury, Nevada

Responsible Facility Owner: Thomas A. Thiele, Project Manager, Industrial Sites, Environmental Restoration Project

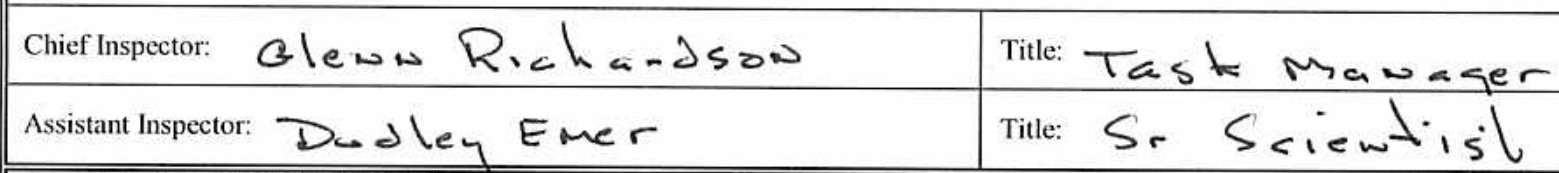

A. GENERAL INSTRUCTIONS

1. All checklist items must be completed and detailed comments made to document the results of the site inspection. The completed checklist is part of the field record of the inspection. Additional pages should be used as necessary to ensure that a complete record is made. Attach the additional pages and number all pages upon completion of the inspection.

2. Any checklist line item marked by an inspector in a SHADED BOX must be fully explained or an appropriate reference to previous reports provided. The purpose of this requirement is to provide a written explanation of inspector observations and the inspector's rationale for conclusions and recommendations. Explanations are to be placed on additional attachments and cross-referenced appropriately. Explanations, in addition to narrative, will take the form of sketches, measurements, and annotated site maps.

3. The site inspection is a walking inspection of the entire site including the perimeter and sufficient transects to be able to inspect the entire surface and all features specifically described in this checklist.

4. Field notes taken to assist in completion of this checklist will become part of the inspection record. No form is specified for field notes; however, they must be legible and in sufficient detail to enable review by succeeding inspectors and the responsible agency.

5. This unit will be inspected annually with formal reporting to the Nevada Division of Environmental Protection to be done annually. The annual letter report will include a summary with this inspection checklist attached.

\begin{tabular}{|c|c|c|c|c|}
\hline B. PREPARATION (To be competed prior to site visit) & YES & NO & \multicolumn{2}{|r|}{ EXPLANATION (required if shaded box is checked) } \\
\hline \multicolumn{5}{|l|}{ 1. Has the Post-Closure Plan been reviewed? } \\
\hline \multicolumn{5}{|l|}{ 2. Have the previous inspection reports been reviewed? } \\
\hline \multicolumn{5}{|l|}{ 3. Were anomalies or trends detected on previous inspections? } \\
\hline \multicolumn{5}{|l|}{$\begin{array}{l}\text { 4. Was maintenance or repair of the landfill unit performed since the } \\
\text { last inspection? }\end{array}$} \\
\hline $\begin{array}{l}\text { a. If yes, has site repair resulted in a change from as-built } \\
\text { conditions? }\end{array}$ & & & NA & \\
\hline $\begin{array}{l}\text { b. If yes (to } 4 a \text { ), are revised as-built plans available that reflect } \\
\text { repair changes? }\end{array}$ & & & NA & \\
\hline
\end{tabular}

\section{SITE INSPECTION PREPARATION}

Assemble the following, as needed, to conduct inspections:

a. Radio, pager, etc.

b. Previous letter report, inspection checklists, repair records, and as-built plans

c. Other miscellaneous support equipment

\section{SITE INSPECTION}

1. Site markers:

a. Is there damage to the fence?

b. Have any posts been damaged or their anchoring weakened?

c. Are any of the use restriction signs damaged or missing?

d. Are all use restriction signs legible?

\begin{tabular}{|l|l|l|}
\hline YES & NO & EXPLANATION (required if shaded box is checked) \\
\hline & - & \\
\hline & & 1 Siqu Down at Gate \\
\hline & & \\
\hline
\end{tabular}


Inspection Requirement: Annual (through 2006)

\section{POST-CLOSURE INSPECTION CHECKLIST}

\section{CAU 262: AREA 25 SEPTIC SYSTEMS AND UDP} CAS 25-05-03, LEACHFIELD

1. Site markers (continued):

e. How many signs need to be replaced?

2. Waste unit cover:

a. Is there evidence of settling?

b. Is there evidence of erosion (wind or water)?

c. Is there evidence of human intrusion into the cover?

d. Is there evidence of large animal intrusion into the cover?

3. Photograph Documentation (optional):

a. Have photographs been taken of the site?

If yes, how many photos were taken?

If yes, has a photographic log been prepared?

\section{E. FIELD CONCLUSIONS}

1. Is there an imminent hazard to the integrity of the site? (Immediate report required)

\begin{tabular}{l|l|l} 
YES & NO & EXPLANATION (required if shaded box is checked) \\
\hline
\end{tabular}

Date reported:

Person/Agency to whom report was made:

2. Are more frequent inspections required?

3. Are existing maintenance/repair actions satisfactory?

4. Is other maintenance/repair necessary?

5. Field conclusions/recommendations:

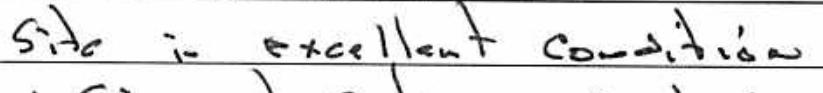

1 Sigm at G-te weeds to be Re hung

\section{F. CERTIFICATION}

I have conducted an inspection of CAS 25-05-03, Leachfield, in accordance with the procedures of the Post-Closure Plan as recorded on this checklist, attached sheets, field notes, photographs, and photograph logs.

Chief Inspector's Signature: /s/ G Richardson

Printed Name:
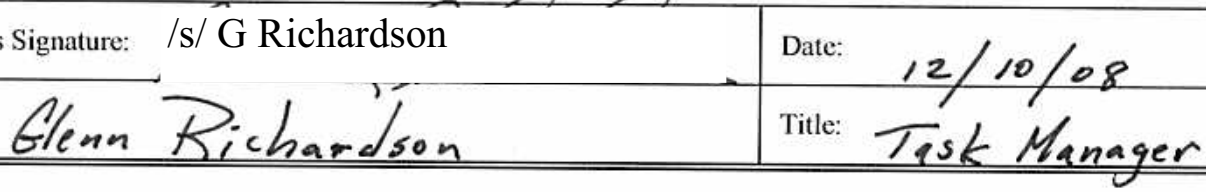


\section{POST-CLOSURE INSPECTION CHECKLIST}

\section{CAU 262: AREA 25 SEPTIC SYSTEMS AND UDP \\ CAS 25-05-08, RADIOACTIVE LEACHFIELD}

\begin{tabular}{|c|c|}
\hline Inspection Date and Time: $12 /<9 / 083 \quad 3: 08 \mathrm{pm}$ & Reason for Inspection: A, w v val \\
\hline Date of Last Post-Closure Inspection: $\Delta / 13 />007$ & Reason for Last Post-Closure Inspection: ANN \\
\hline
\end{tabular}

Responsible Entity: NSTec Environmental Restoration, Nevada Test Site, Mercury, Nevada

Responsible Facility Owner: Thomas A. Thiele, Project Manager, Industrial Sites, Environmental Restoration Project

\begin{tabular}{|l|l||}
\hline Chief Inspector: Glenn Richardson & Title: Task Mgr. \\
\hline Assistant Inspector: Dudley Emer & Title: Sr. Scientist \\
\hline \hline
\end{tabular}

A. GENERAL INSTRUCTIONS

1. All checklist items must be completed and detailed comments made to document the results of the site inspection. The completed checklist is part of the field record of the inspection. Additional pages should be used as necessary to ensure that a complete record is made. Attach the additional pages and number all pages upon completion of the inspection.

2. Any checklist line item marked by an inspector in a SHADED BOX must be fully explained or an appropriate reference to previous reports provided. The purpose of this requirement is to provide a written explanation of inspector observations and the inspector's rationale for conclusions and recommendations. Explanations are to be placed on additional attachments and cross-referenced appropriately.

Explanations, in addition to narrative, will take the form of sketches, measurements, and annotated site maps.

3. The site inspection is a walking inspection of the entire site including the perimeter and sufficient transects to be able to inspect the entire surface and all features specifically described in this checklist.

4. Field notes taken to assist in completion of this checklist will become part of the inspection record. No form is specified for field notes; however, they must be legible and in sufficient detail to enable review by succeeding inspectors and the responsible agency.

5. This unit will be inspected annually with formal reporting to the Nevada Division of Environmental Protection to be done annually. The annual letter report will include a summary with this inspection checklist attached.

B. PREPARATION (To be competed prior to site visit)

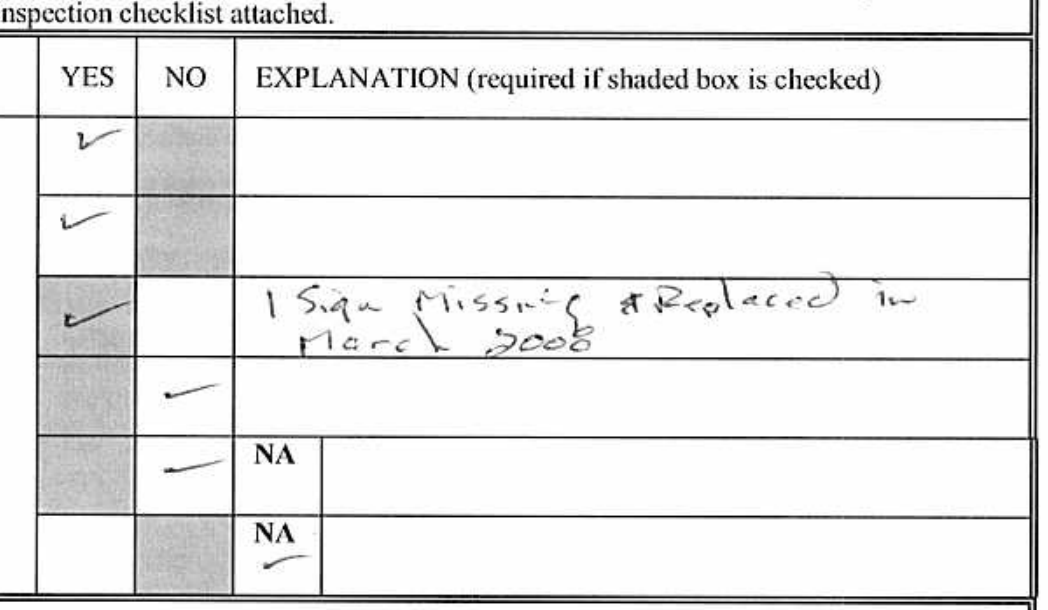

1. Has the Post-Closure Plan been reviewed?

2. Have the previous inspection reports been reviewed?

3. Were anomalies or trends detected on previous inspections?

4. Was maintenance or repair of the landfill unit performed since the last inspection?

a. If yes, has site repair resulted in a change from as-built conditions?

b. If yes (to $4 a$ ), are revised as-built plans available that reflect repair changes?

\section{SITE INSPECTION PREPARATION}

Assemble the following, as needed, to conduct inspections:

a. Radio, pager, etc.

b. Previous letter report, inspection checklists, repair records, and as-built plans

c. Other miscellaneous support equipment

\section{SITE INSPECTION}

1. Site markers:

a. Is there damage to the fence?

b. Have any posts been damaged or their anchoring weakened?

c. Are any of the use restriction signs damaged or missing?

d. Are all use restriction signs legible?

\begin{tabular}{|l|l|l|}
\hline YES & NO & EXPLANATION (required if shaded box is checked) \\
\hline & - & \\
\hline & - & \\
\hline & & I Siq OO ONO \\
\hline & & \\
\hline
\end{tabular}




\section{POST-CLOSURE INSPECTION CHECKLIST}

CAU 262: AREA 25 SEPTIC SYSTEMS AND UDP

CAS 25-05-08, RADIOACTIVE LEACHFIELD

1. Site markers:

e. How many signs need to be replaced?

2. Waste unit cover:

a. Is there evidence of settling?

b. Is there evidence of erosion (wind or water)?

c. Is there evidence of human intrusion into the cover?

d. Is there evidence of large animal intrusion into the cover?

3. Photograph Documentation (optional):

a. Have photographs been taken of the site?

If yes, how many photos were taken?

If yes, has a photographic log been prepared?

\begin{tabular}{|c|c|c|}
\hline YES & NO & EXPLANATION (required if shaded box is checked) \\
\hline \multicolumn{2}{|c|}{0} & Relwaral \\
\hline YES & NO & EXPLANATION (required if shaded box is checked) \\
\hline & & \\
\hline & $\tau$ & \\
\hline & $r$ & \\
\hline & - & \\
\hline YES & NO & EXPLANATION \\
\hline$\longleftarrow$ & & \\
\hline & & \\
\hline 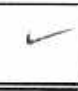 & & $\begin{array}{l}\text { ive }-0857 \\
\text { Log number:ire-0858 } \\
\end{array}$ \\
\hline YES & NO & EXPLANATION (required if shaded box is checked) \\
\hline & $\checkmark$ & \\
\hline
\end{tabular}

Date reported:

Person/Agency to whom report was made:

2. Are more frequent inspections required?

3. Are existing maintenance/repair actions satisfactory?

4. Is other maintenance/repair necessary?

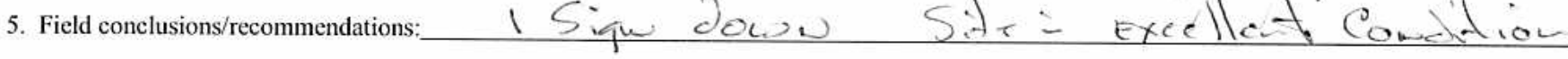

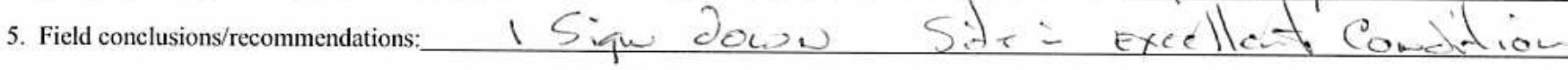

Relava I Sign

\section{F. CERTIFICATION}

I have conducted an inspection of CAS 25-05-08, Radioactive Leachfield, in accordance with the procedures of the Post-Closure Plan as recorded on this checklist, attached sheets, field notes, photographs, and photograph logs.

Chief Inspector's Signature: /s/ G Richardson

Printed Name: Oenn hicherdson Date: $12 / 9 / 08$
Title: Tas K M/anager 
CAU 309: AREA 12 MUCKPILES 
THIS PAGE INTENTIONALLY LEFT BLANK 


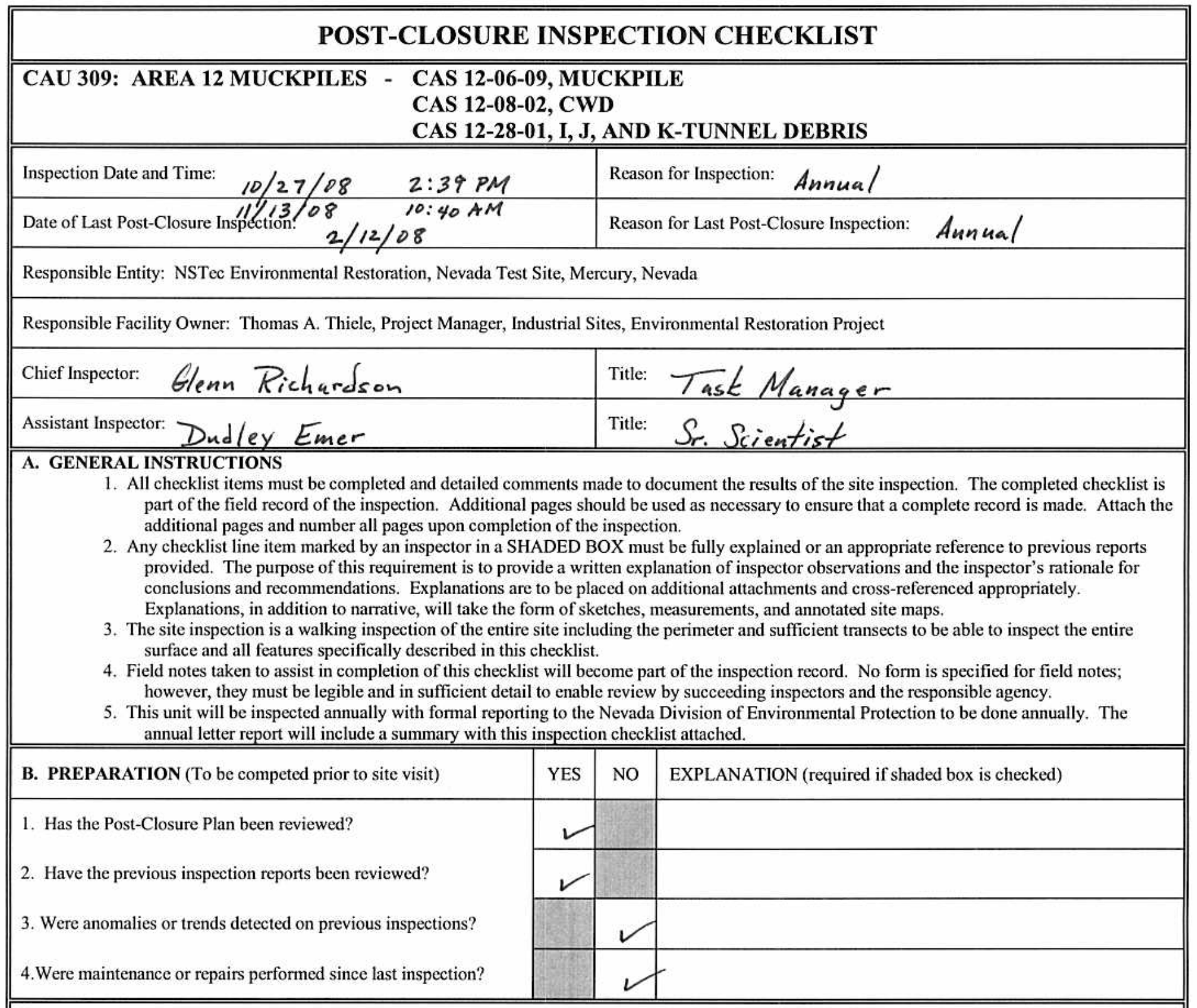

\section{SITE INSPECTION PREPARATION}

Assemble the following, as needed, to conduct inspections:

a. Radio, pager, etc.

b. Previous letter report, inspection checklists, repair records, and as-built plans

c. Other miscellaneous support equipment

\section{SITE INSPECTION}

1. Site markers (CAS 12-06-09): - 11/13/08

a. Have any posts been damaged or their anchoring weakened?

b. Are any of the three (3) use restriction signs damaged or missing?

c. Are all use restriction signs legible?

d. How many signs need to be replaced?

2. Site markers (CAS 12-08-02): $-11 / 13 / 08$

a. Have any posts been damaged or their anchoring weakened?

\begin{tabular}{|l|l|l||}
\hline YES & NO & EXPLANATION (required if shaded box is checked) \\
\hline & & \\
\hline & & \\
\hline & & \\
\hline \multicolumn{1}{|c|}{ Y } & & \\
\hline YES & NO & EXPLANATION (required if shaded box is checked) \\
\hline & & \\
\hline
\end{tabular}




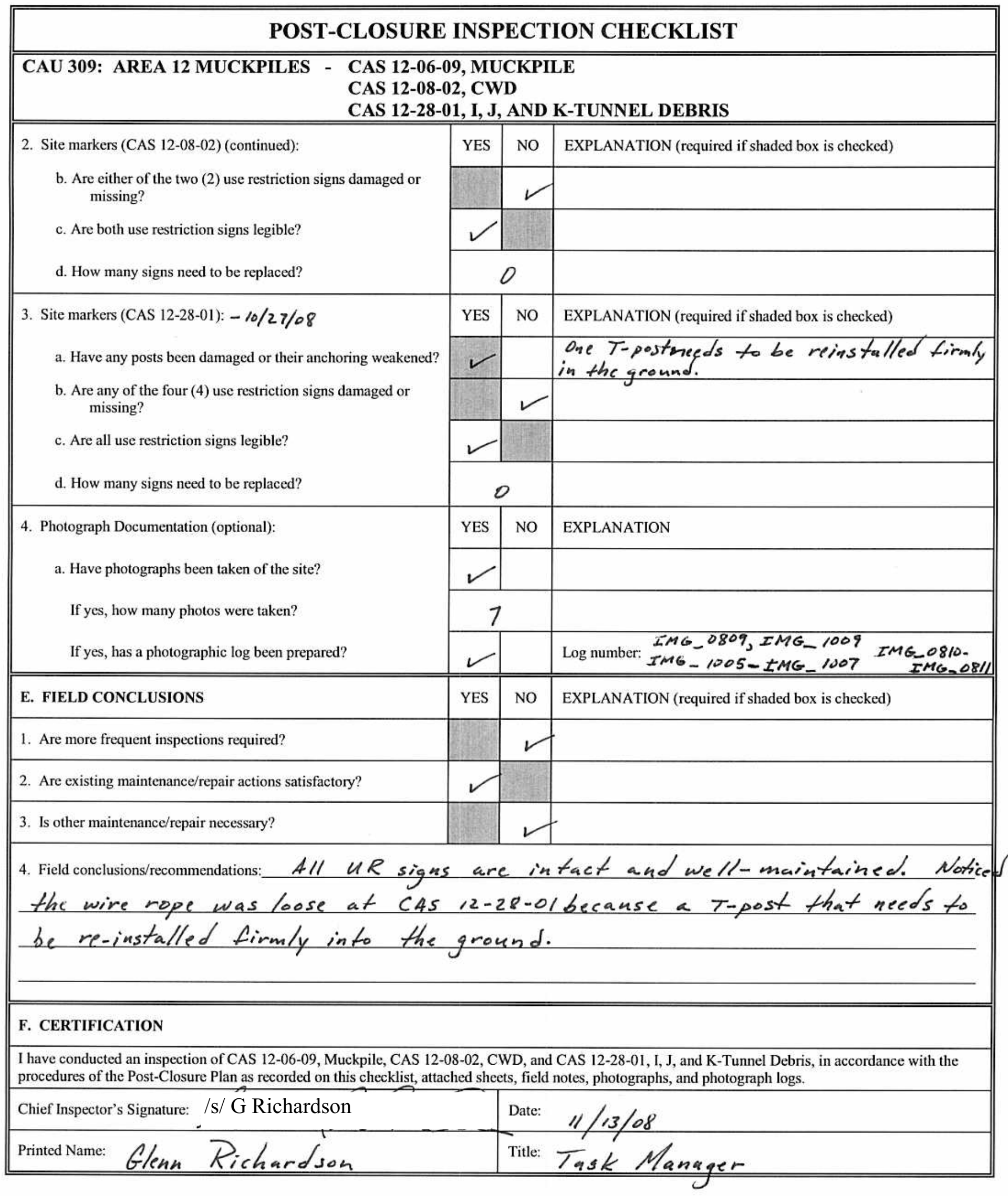




\section{CAU 322: AREAS 1 \& 3 RELEASE SITES AND INJECTION WELLS}


THIS PAGE INTENTIONALLY LEFT BLANK 


\begin{tabular}{|c|c|c|c|}
\hline \multicolumn{4}{|c|}{ POST-CLOSURE INSPECTION CHECKLIST } \\
\hline \multicolumn{4}{|c|}{$\begin{array}{l}\text { CAU 322: AREAS } 1 \text { \& } 3 \text { RELEASE SITES AND INJECTION WELLS } \\
\text { CAS 03-20-05, INJECTION WELLS }\end{array}$} \\
\hline \multicolumn{2}{|l|}{ Inspection Date and Time: i/ $/ 4 / 08 \quad 12: 31, \mathrm{~m}$} & \multicolumn{2}{|c|}{ Reason for Inspection: } \\
\hline \multicolumn{2}{|l|}{ Date of Last Post-Closure Inspection: $1.2 /$ io $/ 2007$} & \multicolumn{2}{|c|}{ Reason for Last Post-Closure Inspection: } \\
\hline \multicolumn{4}{|c|}{ Responsible Entity: NSTec Environmental Restoration, Nevada Test Site, Mercury, Nevada } \\
\hline \multicolumn{4}{|c|}{ Responsible Facility Owner: Thomas A. Thiele, Project Manager, Industrial Sites, Environmental Restoration Project } \\
\hline \multicolumn{2}{|l|}{ 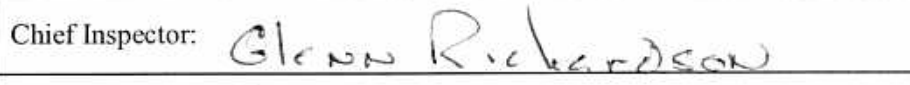 } & \multicolumn{2}{|c|}{ 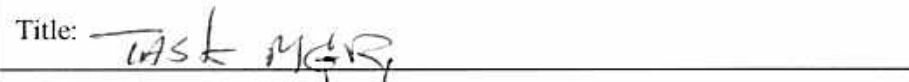 } \\
\hline \multicolumn{2}{|l|}{ Assistant Inspector: Ded eluer } & \multicolumn{2}{|c|}{ Title: So Sriantisil } \\
\hline \multicolumn{4}{|c|}{$\begin{array}{l}\text { A. GENERAL INSTRUCTIONS } \\
\text { 1. All checklist items must be completed and detailed comments made to document the results of the site inspection. The completed checklist is } \\
\text { part of the field record of the inspection. Additional pages should be used as necessary to ensure that a complete record is made. Attach the } \\
\text { additional pages and number all pages upon completion of the inspection. } \\
\text { 2. Any checklist line item marked by an inspector in a SHADED BOX must be fully explained or an appropriate reference to previous reports } \\
\text { provided. The purpose of this requirement is to provide a written explanation of inspector observations and the inspector's rationale for } \\
\text { conclusions and recommendations. Explanations are to be placed on additional attachments and cross-referenced appropriately. } \\
\text { Explanations, in addition to narrative, will take the form of sketches, measurements, and annotated site maps. } \\
\text { 3. The site inspection is a walking inspection of the entire site including the perimeter and sufficient transects to be able to inspect the entire } \\
\text { surface and all features specifically described in this checklist. } \\
\text { 4. Field notes taken to assist in completion of this checklist will become part of the inspection record. No form is specified for field notes; } \\
\text { however, they must be legible and in sufficient detail to enable review by succeeding inspectors and the responsible agency. } \\
\text { 5. This unit will be inspected annually with formal reporting to the Nevada Division of Environmental Protection to be done annually. The } \\
\text { annual letter report will include a summary with this inspection checklist attached. }\end{array}$} \\
\hline B. PREPARATION (To be competed prior to site visit) & YES & NO & EXPLANATION (required if shaded box is checked) \\
\hline \multicolumn{4}{|l|}{ 1. Has the Post-Closure Plan been reviewed? } \\
\hline \multicolumn{4}{|l|}{ 2. Have the previous inspection reports been reviewed? } \\
\hline \multicolumn{4}{|l|}{ 3. Were anomalies or trends detected on previous inspections? } \\
\hline \multicolumn{4}{|l|}{ 4. Were maintenance or repairs performed since last inspection? } \\
\hline $\begin{array}{l}\text { a. If yes, obtain a copy of maintenance records and attach to } \\
\text { checklist. }\end{array}$ & & & NA \\
\hline \multicolumn{4}{|l|}{ C. SITE INSPECTION PREPARATION } \\
\hline \multicolumn{4}{|c|}{$\begin{array}{l}\text { Assemble the following, as needed, to conduct inspections: } \\
\text { a. Radio, pager, etc. } \\
\text { b. Previous letter report, inspection checklists, repair records, and as-built plans } \\
\text { c. Other miscellaneous support equipment }\end{array}$} \\
\hline \multicolumn{4}{|l|}{ D. SITE INSPECTION } \\
\hline 1. Site markers: & YES & NO & EXPLANATION (required if shaded box is checked) \\
\hline a. Is there damage to the fence? & & & 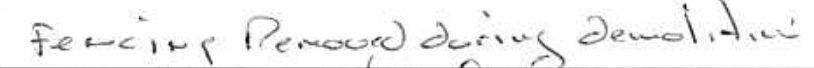 \\
\hline $\begin{array}{l}\text { b. Have any posts been damaged or their anchoring } \\
\text { weakened? }\end{array}$ & & & wow to Reimstoll towciti \\
\hline c. Are any of the use restriction signs damaged or missing? & & & 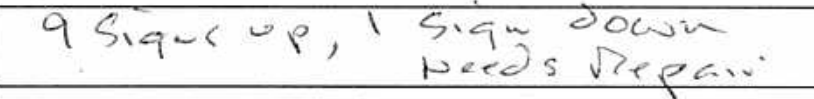 \\
\hline d. Are all use restriction signs legible? & & & \\
\hline e. How many signs need to be replaced? & & & \\
\hline
\end{tabular}




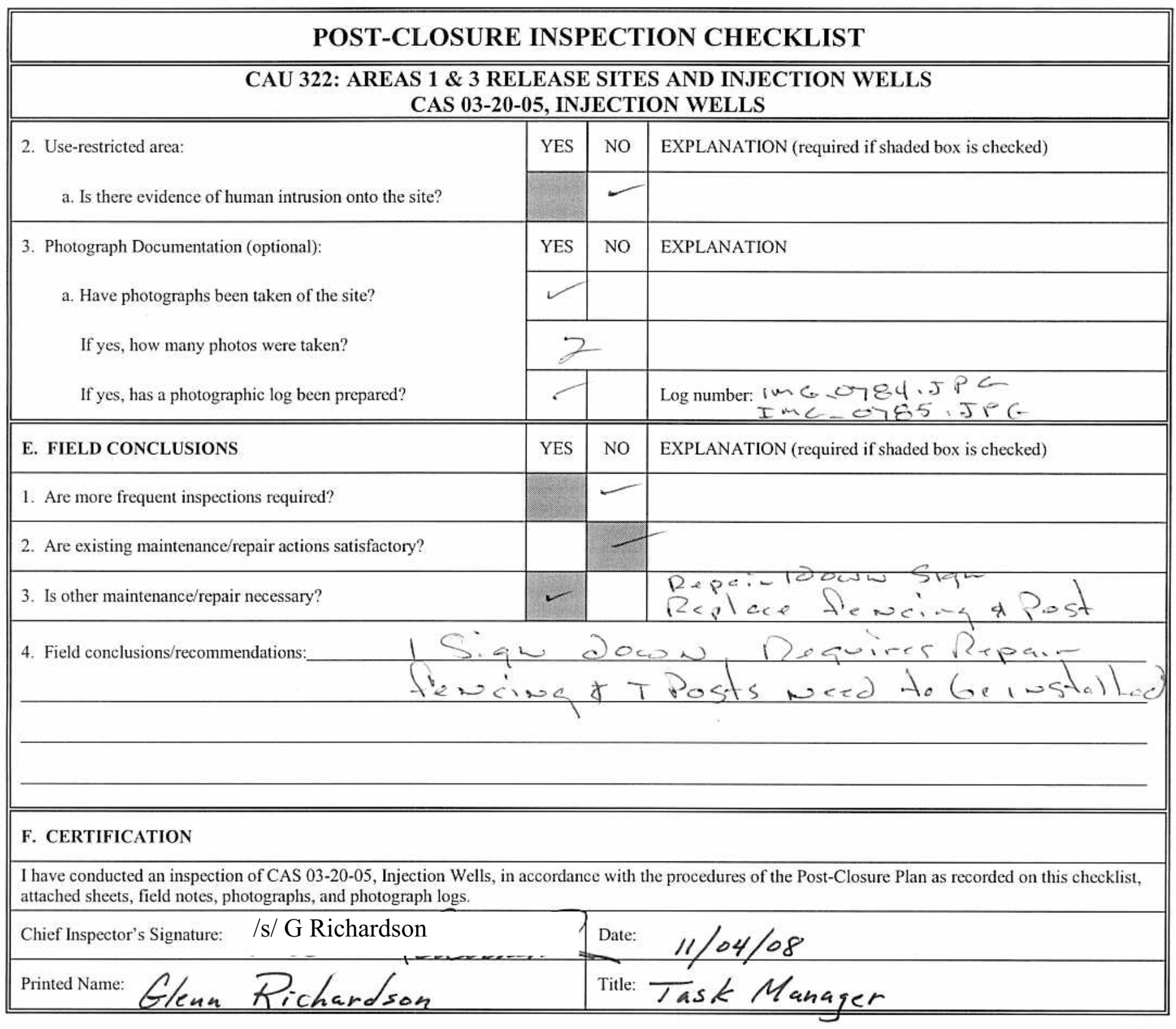

Attachments (check if attached):

$\square$ Maintenance records 


\section{CAU 339: AREA 12 FLEET OPERATIONS}

STEAM CLEANING EFFLUENT 
THIS PAGE INTENTIONALLY LEFT BLANK 


\begin{tabular}{|c|c|c|c|}
\hline \multicolumn{4}{|c|}{ POST-CLOSURE INSPECTION CHECKLIST } \\
\hline \multicolumn{4}{|c|}{$\begin{array}{l}\text { CAU 339: AREA 12 FLEET OPERATIONS STEAM CLEANING EFFLUENT } \\
\text { CAS 12-19-01, A12 FLEET OPS STEAM CLEANING EFFLU. }\end{array}$} \\
\hline \multirow{2}{*}{\multicolumn{2}{|c|}{$\begin{array}{l}\text { Inspection Date and Time: } 10 / 27 / 0809: 50 \\
\text { Date of Last Post-Closure Inspection: } 12110 / 07\end{array}$}} & \multicolumn{2}{|c|}{ Reason for Inspection: $A$ № is sp } \\
\hline & & Reas & for Last Post-Closure Inspection: \\
\hline \multicolumn{4}{|c|}{ Responsible Entity: NSTec Environmental Restoration, Nevada Test Site, Mercury, Nevada } \\
\hline \multicolumn{4}{|c|}{ Responsible Facility Owner: Thomas A. Thiele, Project Manager, Industrial Sites, Environmental Restoration Project } \\
\hline \multicolumn{2}{|c|}{ Chief Inspector: Gle wa R-ckendow } & \multicolumn{2}{|c|}{ Title? T +5 w $C \cdot R$} \\
\hline \multicolumn{2}{|c|}{ Assistant Inspector: D c,ole Eunev- } & \multicolumn{2}{|c|}{ 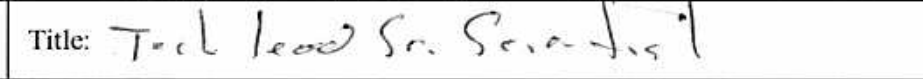 } \\
\hline \multicolumn{4}{|c|}{$\begin{array}{l}\text { A. GENERAL INSTRUCTIONS } \\
\text { 1. All checklist items must be completed and detailed comments made to document the results of the site inspection. The completed checklist is } \\
\text { part of the field record of the inspection. Additional pages should be used as necessary to ensure that a complete record is made. Attach the } \\
\text { additional pages and number all pages upon completion of the inspection. } \\
\text { 2. Any checklist line item marked by an inspector in a SHADED BOX must be fully explained or an appropriate reference to previous reports } \\
\text { provided. The purpose of this requirement is to provide a written explanation of inspector observations and the inspector's rationale for } \\
\text { conclusions and recommendations. Explanations are to be placed on additional attachments and cross-referenced appropriately. } \\
\text { Explanations, in addition to narrative, will take the form of sketches, measurements, and annotated site maps. } \\
\text { 3. The site inspection is a walking inspection of the entire site including the perimeter and sufficient transects to be able to inspect the entire } \\
\text { surface and all features specifically described in this checklist. } \\
\text { 4. Field notes taken to assist in completion of this checklist will become part of the inspection record. No form is specified for field notes; } \\
\text { however, they must be legible and in sufficient detail to enable review by succeeding inspectors and the responsible agency. } \\
\text { 5. This unit will be inspected annually with formal reporting to the Nevada Division of Environmental Protection to be done annually. The } \\
\text { annual letter report will include a summary with this inspection checklist attached. }\end{array}$} \\
\hline B. PREPARATION (To be competed prior to site visit) & YES & NO & EXPLANATION (required if shaded box is checked) \\
\hline \multicolumn{4}{|l|}{ 1. Has the Post-Closure Plan been reviewed? } \\
\hline \multicolumn{4}{|l|}{ 2. Have the previous inspection reports been reviewed? } \\
\hline \multicolumn{4}{|l|}{ 3. Were anomalies or trends detected on previous inspections? } \\
\hline \multicolumn{4}{|l|}{ 4. Were maintenance or repairs performed since last inspection? } \\
\hline \multicolumn{4}{|c|}{ C. SITE INSPECTION PREPARATION } \\
\hline \multicolumn{4}{|c|}{$\begin{array}{l}\text { Assemble the following, as needed, to conduct inspections: } \\
\text { a. Radio, pager, etc. } \\
\text { b. Previous letter report, inspection checklists, repair records, and as-built plans } \\
\text { c. Other miscellaneous support equipment }\end{array}$} \\
\hline \multicolumn{4}{|l|}{ D. SITE INSPECTION } \\
\hline \multirow{2}{*}{$\begin{array}{l}\text { 1. Site markers: } \\
\text { a. Is there damage to the fence? }\end{array}$} & YES & NO & EXPLANATION (required if shaded box is checked) \\
\hline & & & \\
\hline $\begin{array}{l}\text { b. Have any posts been damaged or their anchoring } \\
\text { weakened? }\end{array}$ & & & \\
\hline c. Are any of the use restriction signs damaged or missing? & & 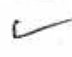 & \\
\hline d. Are all use restriction signs legible? & & & \\
\hline e. How many signs need to be replaced? & & & \\
\hline
\end{tabular}




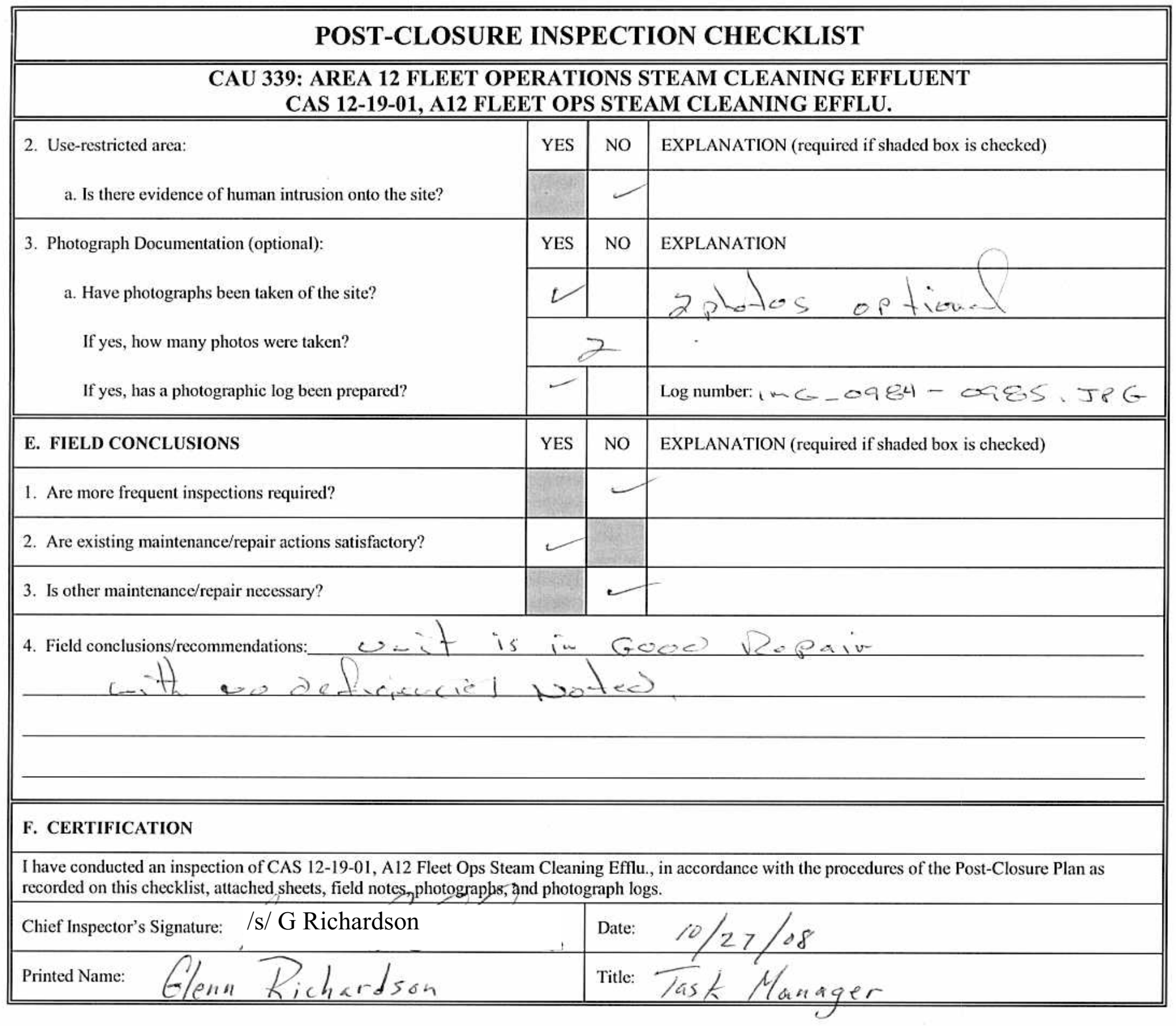


CAU 357: MUD PITS AND WASTE DUMP 
THIS PAGE INTENTIONALLY LEFT BLANK 


\section{POST-CLOSURE INSPECTION CHECKLIST}

\section{CAU 357: MUD PITS AND WASTE DUMPS - CAS 04-26-03, LEAD BRICKS}

\begin{tabular}{||l|l|}
\hline \hline Inspection Date and Time: $11 / 13 / 08: 14: 45$ & Reason for Inspection: Ap \\
\hline Date of Last Post-Closure Inspection: $2 / 23 / 08$ & Reason for Last Post-Closure Inspection: \\
\hline
\end{tabular}

Responsible Entity: NSTec Environmental Restoration, Nevada Test Site, Mercury, Nevada

Responsible Facility Owner: Thomas A. Thiele, Project Manager, Industrial Sites, Environmental Restoration Project

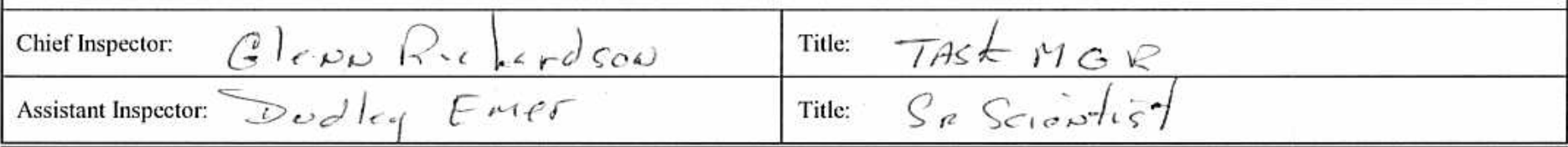

\section{A. GENERAL INSTRUCTIONS}

1. All checklist items must be completed and detailed comments made to document the results of the site inspection. The completed checklist is part of the field record of the inspection. Additional pages should be used as necessary to ensure that a complete record is made. Attach the additional pages and number all pages upon completion of the inspection.

2. Any checklist line item marked by an inspector in a SHADED BOX must be fully explained or an appropriate reference to previous reports provided. The purpose of this requirement is to provide a written explanation of inspector observations and the inspector's rationale for conclusions and recommendations. Explanations are to be placed on additional attachments and cross-referenced appropriately. Explanations, in addition to narrative, will take the form of sketches, measurements, and annotated site maps.

3. The site inspection is a walking inspection of the entire site including the perimeter and sufficient transects to be able to inspect the entire surface and all features specifically described in this checklist.

4. Field notes taken to assist in completion of this checklist will become part of the inspection record. No form is specified for field notes; however, they must be legible and in sufficient detail to enable review by succeeding inspectors and the responsible agency.

5. This unit will be inspected annually with formal reporting to the Nevada Division of Environmental Protection to be done annually. The annual letter report will include a summary with this inspection checklist attached.

\begin{tabular}{|c|c|c|c|}
\hline B. PREPARATION (To be competed prior to site visit) & YES & NO & EXPLANATION (required if shaded box is checked) \\
\hline 1. Has the Post-Closure Plan been reviewed? & 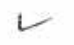 & & \\
\hline 2. Have the previous inspection reports been reviewed? & - & & \\
\hline 3. Were anomalies or trends detected on previous inspections? & & - & \\
\hline 4. Were maintenance or repairs performed since last inspection? & & & \\
\hline
\end{tabular}

\section{SITE INSPECTION PREPARATION}

Assemble the following, as needed, to conduct inspections:

a. Radio, pager, etc.

b. Previous letter report, inspection checklists, repair records, and as-built plans

c. Other miscellaneous support equipment

\section{SITE INSPECTION}

1. Site markers:

a. Have any posts been damaged or their anchoring weakened?

b. Are any of the use restriction signs damaged or missing?

c. Are all use restriction signs legible?

d. How many signs need to be replaced?

2. Use-restricted area:

a. Is there evidence of human intrusion onto the site? 


\begin{tabular}{|c|c|c|c|}
\hline \multicolumn{4}{|c|}{ POST-CLOSURE INSPECTION CHECKLIST } \\
\hline \multicolumn{4}{|c|}{ CAU 357: MUD PITS AND WASTE DUMPS - CAS 04-26-03, LEAD BRICKS } \\
\hline \multirow{2}{*}{$\begin{array}{l}\text { 3. Photograph Documentation (optional): } \\
\text { a. Have photographs been taken of the site? }\end{array}$} & YES & NO & EXPLANATION \\
\hline & $\sim$ & & \\
\hline \multicolumn{4}{|l|}{ If yes, how many photos were taken? } \\
\hline If yes, has a photographic log been prepared? & & & Log number: $\left./ M G_{-} O \varepsilon_{2}-O \varepsilon_{2}\right\rangle$. JY \\
\hline E. FIELD CONCLUSIONS & YES & NO & EXPLANATION (required if shaded box is checked) \\
\hline \multicolumn{4}{|l|}{ 1. Are more frequent inspections required? } \\
\hline \multicolumn{4}{|l|}{ 2. Are existing maintenance/repair actions satisfactory? } \\
\hline 3. Is other maintenance/repair necessary? & & - & \\
\hline \multicolumn{4}{|c|}{ 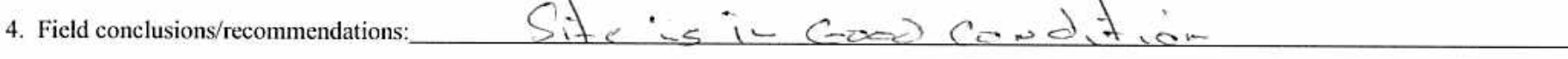 } \\
\hline \multicolumn{4}{|c|}{ 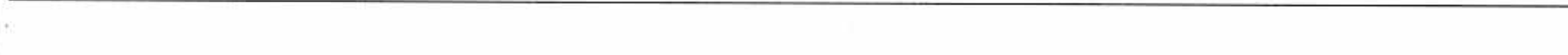 } \\
\hline \multicolumn{4}{|l|}{ F. CERTIFICATION } \\
\hline \multicolumn{4}{|c|}{$\begin{array}{l}\text { I have conducted an inspection of CAS } 04-26-03 \text {, Lead Bricks, in accordance with the procedures of the Post-Closure Plan as recorded on this checklist, } \\
\text { attached sheets, field notes, photographs, and photograph logs. }\end{array}$} \\
\hline \multicolumn{2}{|l|}{ Chief Inspector's Signature: /s/ G Richardson } & Date: & 108 \\
\hline Printed Name: Glenes Tichardson & & Title: & Manager \\
\hline
\end{tabular}




\section{POST-CLOSURE INSPECTION CHECKLIST}

\section{CAU 357: MUD PITS AND WASTE DUMPS - CAS 10-09-06, MUD PIT; STAINS; MATERIAL}

\begin{tabular}{||l|l||}
\hline \hline Inspection Date and Time: $11 / 4 / 08,0: 35 \mathrm{~m}$ & Reason for Inspection: \\
\hline Date of Last Post-Closure Inspection: $1 / 16 / 2008$ & Reason for Last Post-Closure Inspection: \\
\hline Responsible Entity: NSTec Environmental Restoration, Nevada Test Site, Mercury, Nevada \\
\hline Responsible Facility Owner: Thomas A. Thiele, Project Manager, Industrial Sites, Environmental Restoration Project \\
\hline Chief Inspector:
\end{tabular}

A. GENERAL INSTRUCTIONS

1. All checklist items must be completed and detailed comments made to document the results of the site inspection. The completed checklist is part of the field record of the inspection. Additional pages should be used as necessary to ensure that a complete record is made. Attach the additional pages and number all pages upon completion of the inspection.

2. Any checklist line item marked by an inspector in a SHADED BOX must be fully explained or an appropriate reference to previous reports provided. The purpose of this requirement is to provide a written explanation of inspector observations and the inspector's rationale for conclusions and recommendations. Explanations are to be placed on additional attachments and cross-referenced appropriately. Explanations, in addition to narrative, will take the form of sketches, measurements, and annotated site maps.

3. The site inspection is a walking inspection of the entire site including the perimeter and sufficient transects to be able to inspect the entire surface and all features specifically described in this checklist.

4. Field notes taken to assist in completion of this checklist will become part of the inspection record. No form is specified for field notes; however, they must be legible and in sufficient detail to enable review by succeeding inspectors and the responsible agency.

5. This unit will be inspected annually with formal reporting to the Nevada Division of Environmental Protection to be done annually. The annual letter report will include a summary with this inspection checklist attached.

B. PREPARATION (To be competed prior to site visit)

1. Has the Post-Closure Plan been reviewed?

2. Have the previous inspection reports been reviewed?

3. Were anomalies or trends detected on previous inspections?

4. Were maintenance or repairs performed since last inspection?

\section{SITE INSPECTION PREPARATION}

Assemble the following, as needed, to conduct inspections:

a. Radio, pager, etc.

b. Previous letter report, inspection checklists, repair records, and as-built plans

c. Other miscellaneous support equipment

\section{SITE INSPECTION}

1. Site markers:

a. Have any posts been damaged or their anchoring weakened?

b. Are any of the use restriction signs damaged or missing?

c. Are all use restriction signs legible?

d. How many signs need to be replaced?

2. Use-restricted area:

a. Is there evidence of human intrusion onto the site?

\begin{tabular}{|c|c|l||}
\hline YES & NO & EXPLANATION (required if shaded box is checked) \\
\hline & - & \\
\hline & & \\
\hline 0 & \\
\hline YES & NO & EXPLANATION (required if shaded box is checked) \\
\hline & & \\
\hline
\end{tabular}




\section{POST-CLOSURE INSPECTION CHECKLIST}

\section{CAU 357: MUD PITS AND WASTE DUMPS - CAS 10-09-06, MUD PIT; STAINS; MATERIAL}

3. Photograph Documentation (optional):

a. Have photographs been taken of the site?

If yes, how many photos were taken?

If yes, has a photographic log been prepared?

\section{E. FIELD CONCLUSIONS}

1. Are more frequent inspections required?

2. Are existing maintenance/repair actions satisfactory?

3. Is other maintenance/repair necessary?

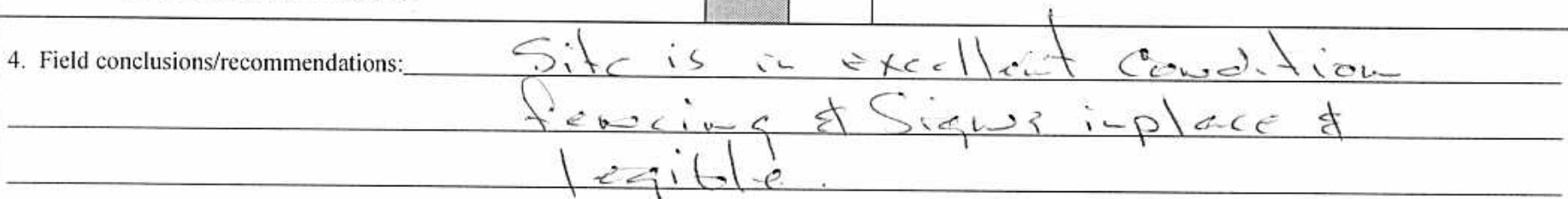

\section{F. CERTIFICATION}

I have conducted an inspection of CAS 10-09-06, Mud Pit; Stains; Material, in accordance with the procedures of the Post-Closure Plan as recorded on this checklist, attached sheets, field notes, photographs, and photograph logs.

\begin{tabular}{l|l}
\hline Chief Inspector's Signature: /s/ G Richardson & Date: $1 / 4 / 08$ \\
\hline Printed Name: G/enn Kichardson & Title: Task Manager
\end{tabular}


POST-CLOSURE INSPECTION CHECKLIST

\section{CAU 357: MUD PITS AND WASTE DUMPS - CAS 25-15-01, WASTE DUMP}

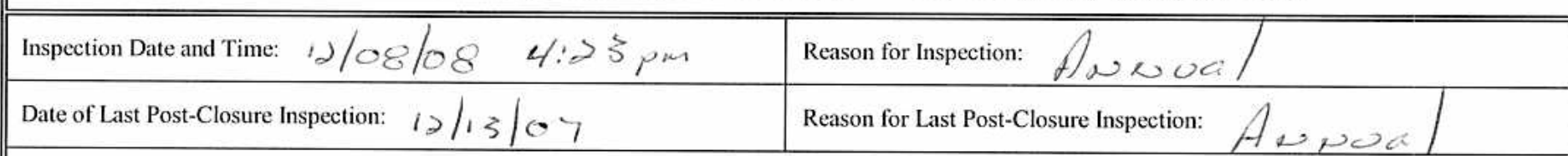

Responsible Entity: NSTec Environmental Restoration, Nevada Test Site, Mercury, Nevada

Responsible Facility Owner: Thomas A. Thiele, Project Manager, Industrial Sites, Environmental Restoration Project

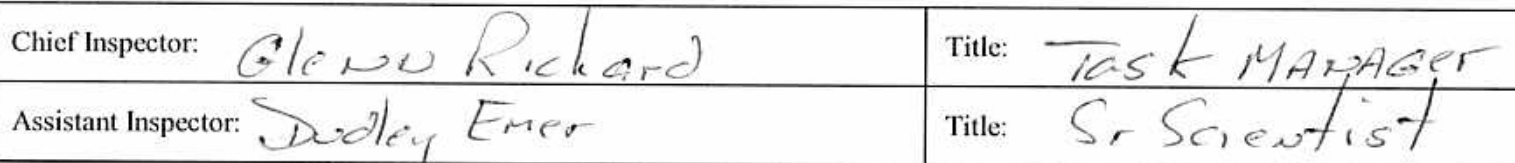

A. GENERAL INSTRUCTIONS

1. All checklist items must be completed and detailed comments made to document the results of the site inspection. The completed checklist is part of the field record of the inspection. Additional pages should be used as necessary to ensure that a complete record is made. Attach the additional pages and number all pages upon completion of the inspection.

2. Any checklist line item marked by an inspector in a SHADED BOX must be fully explained or an appropriate reference to previous reports provided. The purpose of this requirement is to provide a written explanation of inspector observations and the inspector's rationale for conclusions and recommendations. Explanations are to be placed on additional attachments and cross-referenced appropriately. Explanations, in addition to narrative, will take the form of sketches, measurements, and annotated site maps.

3. The site inspection is a walking inspection of the entire site including the perimeter and sufficient transects to be able to inspect the entire surface and all features specifically described in this checklist.

4. Field notes taken to assist in completion of this checklist will become part of the inspection record. No form is specified for field notes; however, they must be legible and in sufficient detail to enable review by succeeding inspectors and the responsible agency.

5. This unit will be inspected annually with formal reporting to the Nevada Division of Environmental Protection to be done annually. The annual letter report will include a summary with this inspection checklist attached.

B. PREPARATION (To be competed prior to site visit)

1. Has the Post-Closure Plan been reviewed?

2. Have the previous inspection reports been reviewed?

3. Were anomalies or trends detected on previous inspections?

4. Were maintenance or repairs performed since last inspection?

\begin{tabular}{|l|l|l||}
\hline YES & NO & EXPLANATION (required if shaded box is checked) \\
\hline & & \\
\hline & & \\
\hline & & \\
\hline
\end{tabular}

\section{SITE INSPECTION PREPARATION}

Assemble the following, as needed, to conduct inspections:

a. Radio, pager, etc.

b. Previous letter report, inspection checklists, repair records, and as-built plans

c. Other miscellaneous support equipment

\section{SITE INSPECTION}

1. Site markers:

a. Are any of the use restriction signs damaged or missing?

b. Are all use restriction signs legible?

c. How many signs need to be replaced?

2. Use-restricted area:

a. Is there evidence of human intrusion onto the site? 


\begin{tabular}{|c|c|c|c|}
\hline \multicolumn{4}{|c|}{ POST-CLOSURE INSPECTION CHECKLIST } \\
\hline \multicolumn{4}{|c|}{ CAU 357: MUD PITS AND WASTE DUMPS - CAS 25-15-01, WASTE DUMP } \\
\hline \multirow{2}{*}{$\begin{array}{l}\text { 3. Photograph Documentation (optional): } \\
\text { a. Have photographs been taken of the site? }\end{array}$} & YES & NO & EXPLANATION \\
\hline & 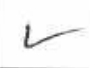 & & \\
\hline If yes, how many photos were taken? & \multicolumn{2}{|c|}{2} & \\
\hline If yes, has a photographic log been prepared? & $\sim$ & & Log number: $100-85 \%, 100-0853$ \\
\hline E. FIELD CONCLUSIONS & YES & NO & EXPLANATION (required if shaded box is checked) \\
\hline 1. Are more frequent inspections required? & & 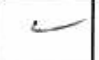 & \\
\hline 2. Are existing maintenance/repair actions satisfactory? & $\sim$ & & \\
\hline 3. Is other maintenance/repair necessary? & & $\sim$ & \\
\hline 4. Field conclusions/recommendations: & 10 & 200 & 1. \\
\hline \multicolumn{4}{|l|}{ F. CERTIFICATION } \\
\hline \multicolumn{4}{|c|}{$\begin{array}{l}\text { I have conducted an inspection of CAS 25-15-01, Waste Dump, in accordance with the procedures of the Post-Closure Plan as recorded on this checklis } \\
\text { attached sheets, field notes, photographs, and photograph logs. }\end{array}$} \\
\hline Chief Inspector's Signature: $/ \mathrm{s} / \mathrm{G}$ Richardson & & Date: & \\
\hline Printed Name: Glenn Fichardson & & Title: & Task Manager \\
\hline
\end{tabular}




\section{CAU 383: AREA 12 E-TUNNEL SITES}


THIS PAGE INTENTIONALLY LEFT BLANK 


\begin{tabular}{|c|c|c|c|}
\hline \multicolumn{4}{|c|}{ POST-CLOSURE INSPECTION CHECKLIST } \\
\hline \multicolumn{4}{|c|}{ CAU 383: AREA 12 E-TUNNEL SITES } \\
\hline \multicolumn{2}{|l|}{ Inspection Date and Time: $10 / 27 / 08$ 11:25am } & \multicolumn{2}{|c|}{ Reason for Inspection: A, wual } \\
\hline \multicolumn{2}{|l|}{ Date of Last Post-Closure Inspection: $2 / 10 / 08$} & \multicolumn{2}{|c|}{ Reason for Last Post-Closure Inspection: } \\
\hline \multicolumn{4}{|c|}{ Responsible Entity: NSTec Environmental Restoration, Nevada Test Site, Mercury, Nevada } \\
\hline \multicolumn{4}{|c|}{ Responsible Facility Owner: Thomas A. Thiele, Project Manager, Industrial Sites, Environmental Restoration Project } \\
\hline \multicolumn{2}{|l|}{ Chief Inspector: } & \multicolumn{2}{|c|}{ Title: $1 A 5 h M \& \sqrt{S}$} \\
\hline \multicolumn{2}{|l|}{ Assistant Inspector: a $201<$ a Emer } & \multicolumn{2}{|c|}{ Title: Sr Scicistist } \\
\hline \multicolumn{4}{|c|}{$\begin{array}{l}\text { A. GENERAL INSTRUCTIONS } \\
\text { 1. All checklist items must be completed and detailed comments made to document the results of the site inspection. The completed checklist is } \\
\text { part of the field record of the inspection. Additional pages should be used as necessary to ensure that a complete record is made. Attach the } \\
\text { additional pages and number all pages upon completion of the inspection. } \\
\text { 2. Any checklist line item marked by an inspector in a SHADED BOX must be fully explained or an appropriate reference to previous reports } \\
\text { provided. The purpose of this requirement is to provide a written explanation of inspector observations and the inspector's rationale for } \\
\text { conclusions and recommendations. Explanations are to be placed on additional attachments and cross-referenced appropriately. } \\
\text { Explanations, in addition to narrative, will take the form of sketches, measurements, and annotated site maps. } \\
\text { 3. The site inspection is a walking inspection of the entire site including the perimeter and sufficient transects to be able to inspect the entire } \\
\text { surface and all features specifically described in this checklist. } \\
\text { 4. Field notes taken to assist in completion of this checklist will become part of the inspection record. No form is specified for field notes; } \\
\text { however, they must be legible and in sufficient detail to enable review by succeeding inspectors and the responsible agency. } \\
\text { 5. This unit will be inspected annually with formal reporting to the Nevada Division of Environmental Protection to be done annually. The } \\
\text { annual letter report will include a summary with this inspection checklist attached. }\end{array}$} \\
\hline B. PREPARATION (To be competed prior to site visit) & YES & NO & EXPLANATION (required if shaded box is checked) \\
\hline \multicolumn{4}{|l|}{ 1. Has the Post-Closure Plan been reviewed? } \\
\hline \multicolumn{4}{|l|}{ 2. Have the previous inspection reports been reviewed? } \\
\hline \multicolumn{4}{|l|}{ 3. Were anomalies or trends detected on previous inspections? } \\
\hline \multicolumn{2}{|l|}{ 4. Were maintenance or repairs performed since last inspection? } & - & \\
\hline \multicolumn{4}{|l|}{ C. SITE INSPECTION PREPARATION } \\
\hline \multicolumn{4}{|c|}{$\begin{array}{l}\text { Assemble the following, as needed, to conduct inspections: } \\
\text { a. Radio, pager, etc. } \\
\text { b. Previous letter report, inspection checklists, repair records, and as-built plans } \\
\text { c. Other miscellaneous support equipment }\end{array}$} \\
\hline \multicolumn{4}{|l|}{ D. SITE INSPECTION } \\
\hline \multirow{2}{*}{$\begin{array}{l}\text { 1. Site markers: } \\
\text { a. Have any posts been damaged or their anchoring weakened? }\end{array}$} & YES & NO & EXPLANATION (required if shaded box is checked) \\
\hline & & & $\begin{array}{l}\text { Radon the vec Broben at } \\
\text { TLD sta bu Bad }\end{array}$ \\
\hline \multicolumn{4}{|l|}{ b. Are any of the 11 use restriction signs damaged or missing? } \\
\hline \multicolumn{4}{|l|}{ c. Are all use restriction signs legible? } \\
\hline d. How many signs need to be replaced? & & - & \\
\hline 2. Use-restricted area: & YES & NO & EXPLANATION (required if shaded box is checked) \\
\hline a. Is there evidence of human intrusion onto the site? & & & \\
\hline
\end{tabular}




\begin{tabular}{|c|c|c|}
\hline \multicolumn{3}{|c|}{ POST-CLOSURE INSPECTION CHECKLIST } \\
\hline \multicolumn{3}{|c|}{$\begin{aligned} & \text { CAU 383: AREA } 12 \text { E-TUNNEL SITES } \text { - CAS 12-06-06, MUCKPILE } \\
& \text { - CAS 12-25-02, OIL SPILL } \\
& \text { - CAS 12-28-02, RADIOACTIVE MATERIAL } \\
&\end{aligned}$} \\
\hline \multirow{2}{*}{$\begin{array}{l}\text { 3. Photograph Documentation (optional): } \\
\text { a. Have photographs been taken of the site? }\end{array}$} & YES & EXPLANATION \\
\hline & & \\
\hline \multicolumn{3}{|l|}{ If yes, how many photos were taken? } \\
\hline If yes, has a photographic log been prepared? & & 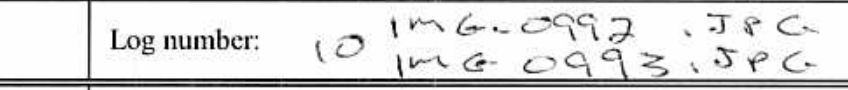 \\
\hline E. FIELD CONCLUSIONS & YES & EXPLANATION (required if shaded box is checked) \\
\hline \multicolumn{3}{|l|}{ 1. Are more frequent inspections required? } \\
\hline \multicolumn{3}{|l|}{ 2. Are existing maintenance/repair actions satisfactory? } \\
\hline \multicolumn{3}{|l|}{ 3. Is other maintenance/repair necessary? } \\
\hline \multicolumn{3}{|c|}{ 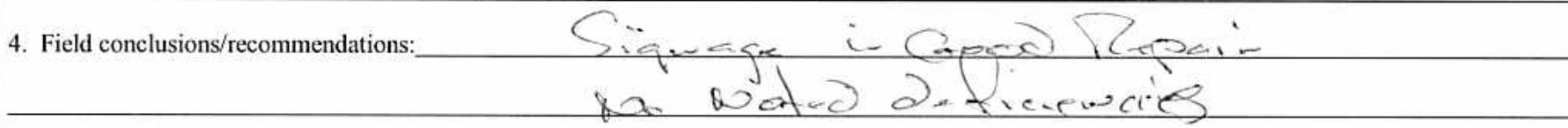 } \\
\hline \multicolumn{3}{|l|}{ F. CERTIFICATION } \\
\hline \multicolumn{3}{|c|}{$\begin{array}{l}\text { I have conducted an inspection of CAS 12-06-06, Muckpile, CAS 12-25-02, Oil Spill, and CAS 12-28-02, Radioactive Material, in accordance with the } \\
\text { procedures of the Post-Closure Plan as recorded on this checklist, attached sheets, field notes, photographs, and photograph logs. }\end{array}$} \\
\hline \multicolumn{2}{|l|}{ Chief Inspector's Signature: /s/ G Richardson } & Date: $\quad 10 / 27 / 08$ \\
\hline Printed Name: Gleun Richardson & & Title: Task Manager \\
\hline
\end{tabular}




\section{CAU 476: AREA 12 T-TUNNEL MUCKPILE and CAU 559: T-TUNNEL COMPRESSOR/BLOWER PAD}


THIS PAGE INTENTIONALLY LEFT BLANK 


\begin{tabular}{|c|c|}
\hline \multicolumn{2}{|c|}{ POST-CLOSURE INSPECTION CHECKLIST } \\
\hline \multicolumn{2}{|c|}{$\begin{array}{l}\text { CAU 476: AREA } 12 \text { T-TUNNEL MUCKPILE - CAS 12-06-02, MUCKPILE } \\
\text { CAU 559: T-TUNNEL COMPRESSOR/BLOWER PAD - CAS 12-25-13, OIL STAINED SOIL AND CONCRETE }\end{array}$} \\
\hline Inspection Date and Time: $12 / 11 / 08$ & Reason for Inspection: Ann ual \\
\hline Date of Last Post-Closure Inspection: None - Ist inspection & Reason for Last Post-Closure Inspection: \\
\hline \multicolumn{2}{|c|}{ Responsible Entity: NSTec Environmental Restoration, Nevada Test Site, Mercury, Nevada } \\
\hline \multicolumn{2}{|c|}{ Responsible Facility Owner: Thomas A. Thiele, Project Manager, Industrial Sites, Environmental Restoration Project } \\
\hline Chief Inspector: Glenn Richardson / Reed Poderis & Title: Task Mana \\
\hline Assistant Inspector: Mike Floyd & Title: $F_{1}$ \\
\hline
\end{tabular}

\section{A. GENERAL INSTRUCTIONS}

- Complete all checklist items.

- If a SHADED BOX is checked, provide detailed information regarding what was found and/or appropriate references to other documents that have the information (e.g., Maintenance Order Form for CAS 25-01-07 dated 3/28/2008).

- All documentation must be legible and clear.

\begin{tabular}{|c|c|c|c|}
\hline B. PREPARATION (To be competed prior to site visit) & YES & NO & EXPLANATION (required if shaded box is checked) \\
\hline \multicolumn{4}{|l|}{ 1. Has the Post-Closure Plan been reviewed? } \\
\hline 2. Have the previous inspection reports been reviewed? & & & $N / A-1 s t$ in spection \\
\hline 3. Were anomalies or trends detected on previous inspections? & & & $N / A$ - Ist inspection \\
\hline 4. Were maintenance or repairs performed since last inspection? & & & $N / A-\|$ \\
\hline
\end{tabular}

\section{SITE INSPECTION PREPARATION}

Assemble the following, as needed, to conduct inspections:
a. Radio, pager, etc.
b. Camera, digital storage drive, and extra batteries
c. Previous Post-Closure Report, Inspection Checklists, repair records, and as-built plans
d. Tape measure
e. Other miscellaneous support equipment

\section{SITE INSPECTION}

\section{- The site inspection to certify that markers and postings are in place, intact, and readable. Access to the use-restricted area is not} permitted without U.S. Government permission. The checklist should be completed during the site inspection.

- If a shaded box is checked, add detailed comments to document the results of the site inspection. Information provided should be of sufficient detail to enable reconstruction of observations regarding field conditions. Information can take the form of written narrative, sketches, measurements, and annotated site maps, all of which should be placed on additional attachments (if needed) and cross-reference appropriately. Attach the additional pages and number all pages upon completion of the inspection. The completed checklist is part of the field record of the inspection.

- Field notes taken to assist in completion of this checklist will become part of the inspection record. No form is specified for field notes, and additional field notes are not required if the checklist and associated attachments adequately describe site conditions.

1. Site markers:

a. Is there damage to the blockade gate?

b. Is the gate lock in place and functional?

\begin{tabular}{|l|l|l||} 
YES & NO & EXPLANATION (required if shaded box is checked) \\
\hline & & \\
\hline & & \\
\hline
\end{tabular}




\section{POST-CLOSURE INSPECTION CHECKLIST}

\section{CAU 476: AREA 12 T-TUNNEL MUCKPILE - CAS 12-06-02, MUCKPILE}

CAU 559: T-TUNNEL COMPRESSOR/BLOWER PAD - CAS 12-25-13, OIL STAINED SOIL AND CONCRETE

1. Site markers (continued):

c. Have any posts been damaged or their anchoring weakened?

d. Is the use restriction sign damaged or missing?

e. Is the use restriction sign legible?

f. Does the sign have the required wording (check wording on the sign):

WARNING
Radiologically Contaminated Areas
Beyond This Point
FFACO Sites
CAU 476, Area 12, T-Tunnel Sites
CAS 12-06-02, Muckpile
CAU 559, T-Tunnel Compressor/Blower Pad
CAS 12-25-13, Oil-Stained Soil and Concrete
CAU 478, Area 12, T-Tunnel Ponds
CAS 12-23-01, Ponds (5), RAD Area
CAU 309, Area 12, Muckpiles
CAS 12-06-09, Muckpile
CAS 12-08-02, Contaminated Waste Dumps
CAS 12-28-01, I, J, and K-Tunnel
Access to this area is not permitted without
U.S. Government permission.
Before working in this area,
Contact Real Estate Services at 295-2528

g. Does the sign need to be replaced?

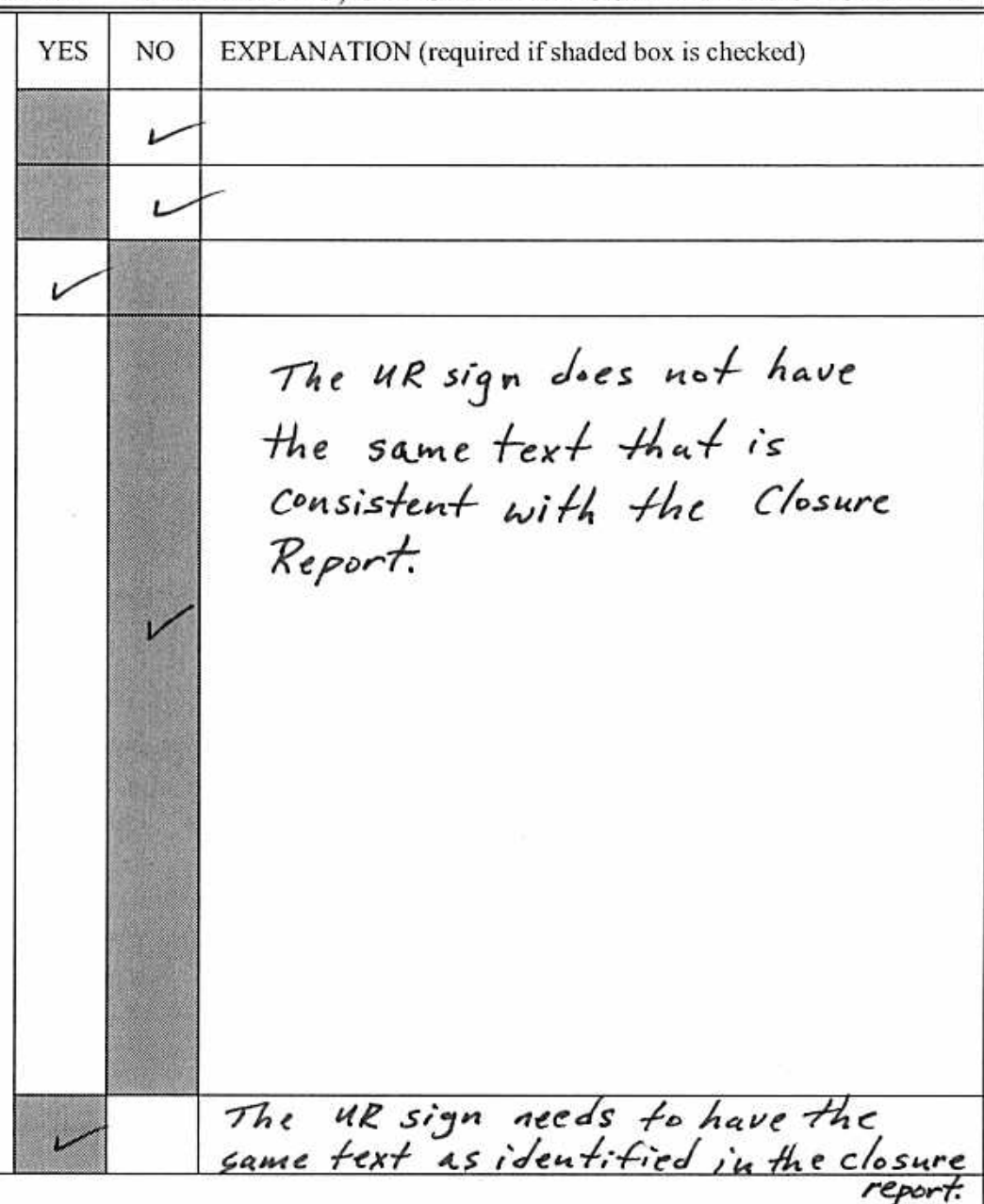

Photograph Instructions:

- Photographs should be taken to document maintenance/repair needs at the site. These will be used to plan maintenance/repair activities and are not intended for use in the post-closure annual report.

- Anomalous features or new features (such as changes in adjacent area land use) should be photographed.

- Other photographs are optional.

- A photograph log entry will be made for each photograph taken.

2. Photograph Documentation:

a. Have photographs been taken of the site?

If yes, how many photos were taken?

If yes, has a photographic log been prepared?

\begin{tabular}{|c|c|c|c|}
\hline E. FIELD CONCLUSIONS & YES & NO & EXPLANATION (required if shaded box is checked) \\
\hline 1. Are more frequent inspections required? & & & \\
\hline 2. Are existing maintenance/repair actions satisfactory? & & & $N / A$ \\
\hline 3. Are maintenance/repair actions necessary? & & & If "yes", describe in Field conclusions/recommendations \\
\hline
\end{tabular}




\section{POST-CLOSURE INSPECTION CHECKLIST}

CAU 476: AREA 12 T-TUNNEL MUCKPILE - CAS 12-06-02, MUCKPILE

CAU 559: T-TUNNEL COMPRESSOR/BLOWER PAD - CAS 12-25-13, OIL STAINED SOIL AND CONCRETE

E. FIELD CONCLUSIONS (continued)

4. Field conclusions/recommendations:. The access gate appears to be secured and the $U R$ signage is visible and legible. However, the text on the megla $U R$ sign is not consistent with the Closure Report and needs to be revised.

\section{F. CERTIFICATION}

I have conducted an inspection of CAS 12-06-02, Muckpile, and CAS 12-25-13, Oil Stained Soil and Concrete, in accordance with the procedures of the Post-Closure Plan as recorded on this checklist, attached sheets.,-field notes, photographs, and photograph logs.

Chief Inspector's Signature: /s/ G Richardson

Printed Name:

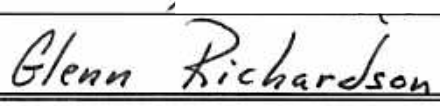

Date:

$12 / 11 / 08$

Title: Task Manager

Required Attachments:

- Field Notes (if any)

- Photos (or note File Location: S:INTS\ER Share Photos \CAu 476-559 \12-11-2008

Distribution: Original - Industrial Sites Project Manager

Copy - Task Manager

\section{G. VERIFICATION}

I have reviewed this cheqklist and attachments and have verified that it is complete.

Signature: /s/ R Poderis

Date: $\quad 1-20-09$

Printed Name: Thomas A. Thiele (or designee) Peed Poleris

Distribution: Original - Task Manager 
THIS PAGE INTENTIONALLY LEFT BLANK 
CAU 477: AREA 12 N-TUNNEL MUCKPILE 
THIS PAGE INTENTIONALLY LEFT BLANK 


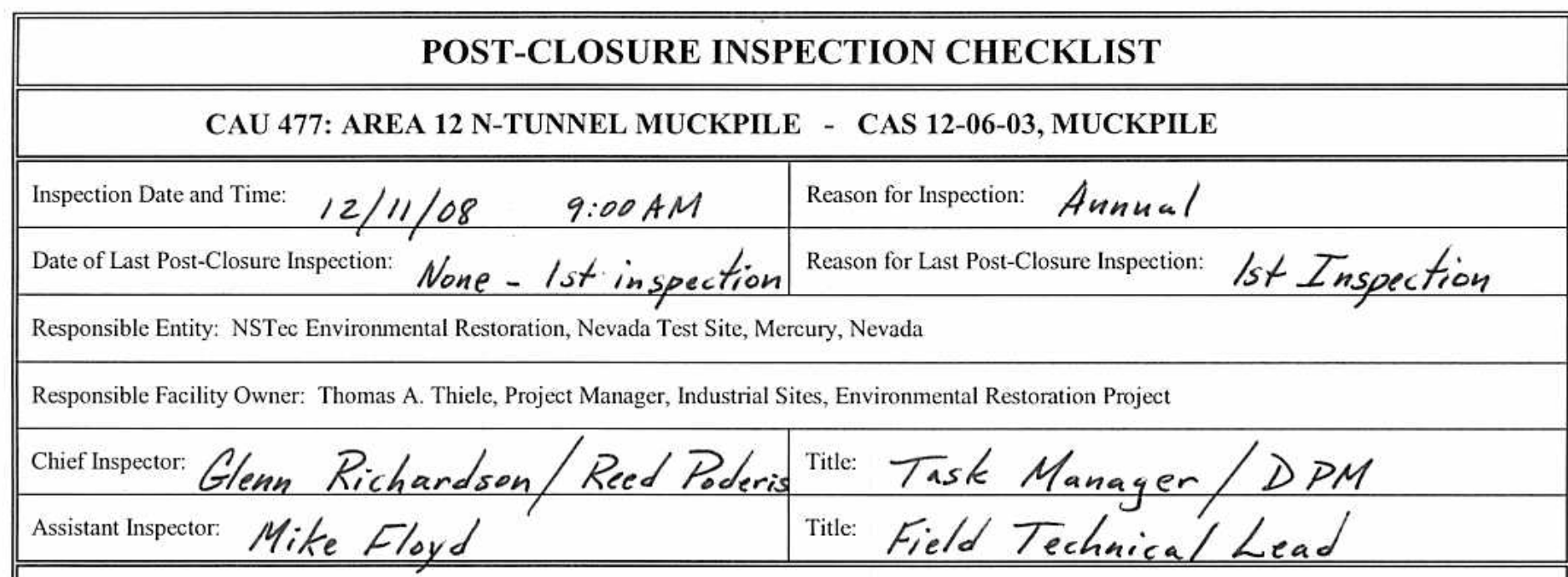

A. GENERAL INSTRUCTIONS

- Complete all checklist items.

- If a SHADED BOX is checked, provide detailed information regarding what was found and/or appropriate references to other documents that have the information (e.g., Maintenance Order Form for CAS 25-01-07 dated 3/28/2008).

- All documentation must be legible and clear.

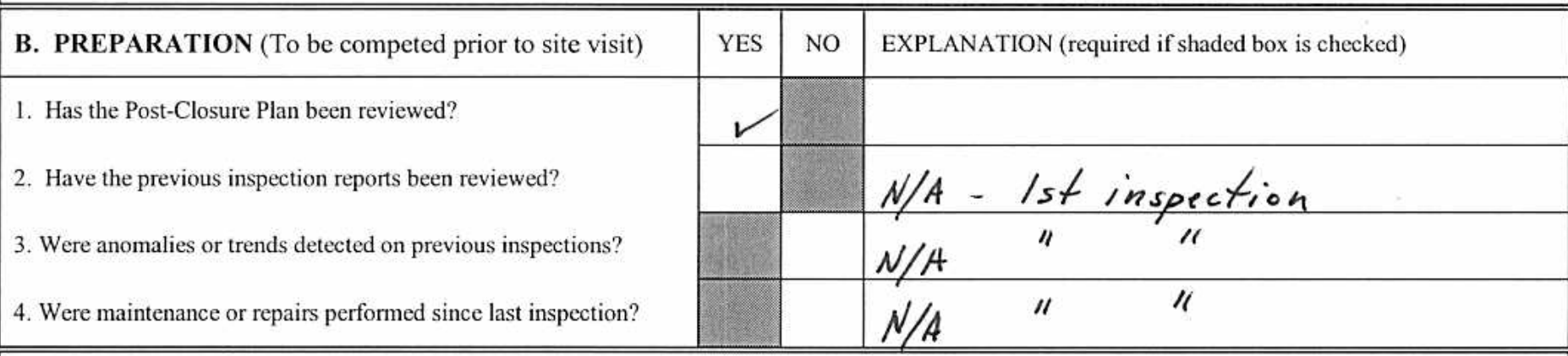

\section{SITE INSPECTION PREPARATION}

Assemble the following, as needed, to conduct inspections:
a. Radio, pager, etc.
b. Camera, digital storage drive, and extra batteries
c. Previous Post-Closure Report, Inspection Checklists, repair records, and as-built plans
d. Tape measure
e. Other miscellaneous support equipment

\section{SITE INSPECTION}

- The site inspection to certify that the posting is in place, intact, and readable. Access to the use-restricted area is not permitted without U.S. Government permission. The checklist should be completed during the site inspection.

- If a shaded box is checked, add detailed comments to document the results of the site inspection. Information provided should be of sufficient detail to enable reconstruction of observations regarding field conditions. Information can take the form of written narrative, sketches, measurements, and annotated site maps, all of which should be placed on additional attachments (if needed) and cross-reference appropriately. Attach the additional pages and number all pages upon completion of the inspection. The completed checklist is part of the field record of the inspection.

- Field notes taken to assist in completion of this checklist will become part of the inspection record. No form is specified for field notes, and additional field notes are not required if the checklist and associated attachments adequately describe site conditions.

1. Site markers:

a. Is there damage to the blockade gate?

b. Is the gate lock in place and functional?

\begin{tabular}{|l|l|l||} 
YES & NO & EXPLANATION (required if shaded box is checked) \\
\hline & & \\
\hline & & \\
\hline
\end{tabular}




\section{POST-CLOSURE INSPECTION CHECKLIST}

\section{CAU 477: AREA 12 N-TUNNEL MUCKPILE - CAS 12-06-03, MUCKPILE}

1. Site markers (continued):

c. Have any posts been damaged or their anchoring weakened?

d. Is the use restriction sign damaged or missing?

e. Is the use restriction sign legible?

f. Does the sign have the required wording?

WARNING

Lead Contaminated Area Beyond This Point

FFACO Site

CAU 477, Area 12, N-Tunnel Muckpile CAS 12-06-03, Muckpile

Access to this area is not permitted without

U.S. Government permission.

Before working in this area,

Contact Real Estate Services at 295-2528

g. Does the sign need to be replaced?

Photograph Instructions:

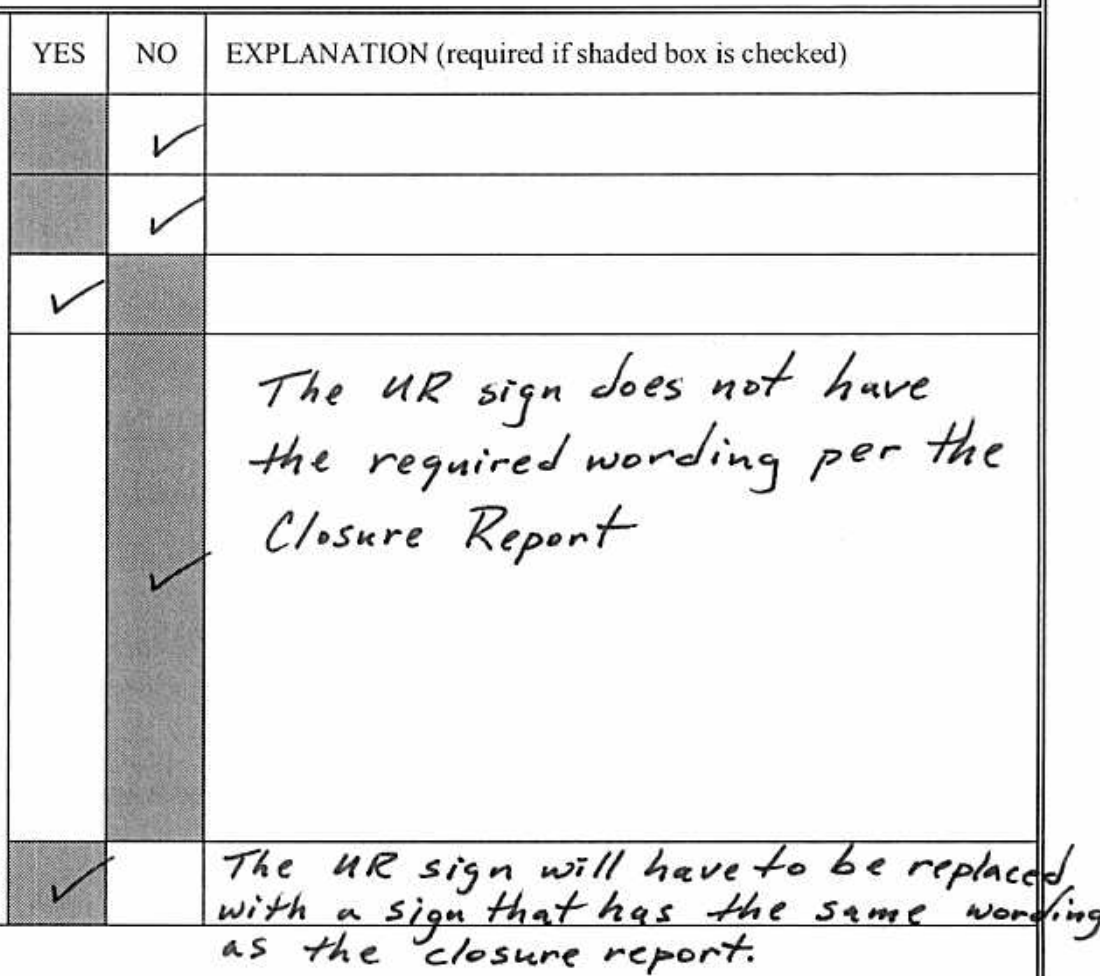

- Photographs should be taken to document maintenance/repair needs at the site. These will be used to plan maintenance/repair activities and are not intended for use in the post-closure annual report.

- Anomalous features or new features (such as changes in adjacent area land use) should be photographed.

- Other photographs are optional.

- A photograph log entry will be made for each photograph taken.

2. Photograph Documentation:

a. Have photographs been taken of the site?

If yes, how many photos were taken?

If yes, has a photographic log been prepared?

\section{E. FIELD CONCLUSIONS}

1. Are more frequent inspections required?

2. Are existing maintenance/repair actions satisfactory?

3. Are maintenance/repair actions necessary?

\begin{tabular}{|c|c|c|}
\hline YES & NO & EXPLANATION \\
\hline & & \\
\hline YES & NO & EXPLANATION (required if shaded box is checked) \\
\hline & & $N / A$ \\
\hline & & If "yes", describe below \\
\hline
\end{tabular}

4. Field conclusions/recommendations: The access gate is sturdy and secured. The mega $U R$ sign is visible and legible; however, it does not have the same wording as per the Closure Report. The UR sign will need to be replaced. 


\section{POST-CLOSURE INSPECTION CHECKLIST}

\section{CAU 477: AREA 12 N-TUNNEL MUCKPILE - CAS 12-06-03, MUCKPILE}

\section{F. CERTIFICATION}

I have conducted an inspection of CAS 12-06-03, Muckpile, in accordance with the procedures of the Post-Closure Plan as recorded on this checklist, attached sheets, field notes, photographs, and photograph logs.

Chief Inspector's Signature: /s/ G Richardson

Printed Name:

Glenn Richardson
Date:

$12 / 11 / 08$

Title: Task Manager

\section{Required Attachments:}

- Field Notes (if any)

- Photos (or note File Location: S:INTS\ER Sharel Photos $\backslash$ CAu 477 $\backslash 12-11-2008$ )

Distribution: Original - Industrial Sites Project Manager

$$
\text { Copy - Task Manager }
$$

\section{G. VERIFICATION}

I have reviewed this checklist and attachments and have verified that it is complete.

\begin{tabular}{|l|l|}
\hline Signature: /s/ R Poderis & Date: 1-20-0 1 .
\end{tabular}

Printed Name: Thomas A. Thielle (or designee) Reed foleris

Distribution: Original - Task Manager 
THIS PAGE INTENTIONALLY LEFT BLANK 
CAU 478: AREA 12 T-TUNNEL PONDS 
THIS PAGE INTENTIONALLY LEFT BLANK 


\section{POST-CLOSURE INSPECTION CHECKLIST}

CAU 478: AREA 12 T-TUNNEL PONDS - CAS 12-23-01, PONDS (5), RAD AREA

\begin{tabular}{|l|l|l|}
\hline \hline Inspection Date and Time: $12 / 16 / 08 \quad 9: 35 \mathrm{AM}$ & Reason for Inspection: Ann ual \\
\hline Date of Last Post-Closure Inspection: None - Ist inspection & Reason for Last Post-Closure Inspection: Ist inspection
\end{tabular}

Responsible Entity: NSTec Environmental Restoration, Nevada Test Site, Mercury, Nevada

Responsible Facility Owner: Thomas A. Thiele, Project Manager, Industrial Sites, Environmental Restoration Project

\begin{tabular}{l|l||}
\hline Chief Inspector: Glenn Richardson/Reed Poderis & Title: Task Manager/DPM \\
\hline Assistant Inspector: Mike Floyd & Title: Field Technical Lead \\
\hline
\end{tabular}

\section{A. GENERAL INSTRUCTIONS}

- Complete all checklist items.

- If a SHADED BOX is checked, provide detailed information regarding what was found and/or appropriate references to other documents that have the information (e.g., Maintenance Order Form for CAS 25-01-07 dated 3/28/2008).

- All documentation must be legible and clear.

\begin{tabular}{|l|l|l|l|}
\hline \hline B. PREPARATION (To be competed prior to site visit) & YES & NO & EXPLANATION (required if shaded box is checked) \\
\hline 1. Has the Post-Closure Plan been reviewed? & & & \\
\cline { 2 - 4 } 2. Have the previous inspection reports been reviewed? & & & \\
\cline { 2 - 4 } 3. Were anomalies or trends detected on previous inspections? & & &
\end{tabular}

\section{SITE INSPECTION PREPARATION}

Assemble the following, as needed, to conduct inspections:
a. Radio, pager, etc.
b. Camera, digital storage drive, and extra batteries
c. Previous Post-Closure Report, Inspection Checklists, repair records, and as-built plans
d. Tape measure
e. Other miscellaneous support equipment

\section{SITE INSPECTION}

- The site inspection to certify that markers and postings are in place, intact, and readable. Access to the use-restricted area is not permitted without U.S. Government permission. The checklist should be completed during the site inspection.

- If a shaded box is checked, add detailed comments to document the results of the site inspection. Information provided should be of sufficient detail to enable reconstruction of observations regarding field conditions. Information can take the form of written narrative, sketches, measurements, and annotated site maps, all of which should be placed on additional attachments (if needed) and cross-reference appropriately. Attach the additional pages and number all pages upon completion of the inspection. The completed checklist is part of the field record of the inspection.

- Field notes taken to assist in completion of this checklist will become part of the inspection record. No form is specified for field notes, and additional field notes are not required if the checklist and associated attachments adequately describe site conditions.

1. Site markers:

a. Is there damage to the blockade gate?

b. Is the gate lock in place and functional?

\begin{tabular}{|l|l|l||}
\hline YES & NO & EXPLANATION (required if shaded box is checked) \\
\hline & & \\
\hline & & \\
\hline
\end{tabular}




\section{POST-CLOSURE INSPECTION CHECKLIST}

\section{CAU 478: AREA 12 T-TUNNEL PONDS - CAS 12-23-01, PONDS (5), RAD AREA}

1. Site markers (continued):

c. Have any posts been damaged or their anchoring weakened?

d. Is the use restriction sign damaged or missing?

e. Is the use restriction sign legible?

f. Does the sign have the required wording (check wording on the sign):

WARNING
Radiologically Contaminated Areas
Beyond This Point
FFACO Sites
CAU 476, Area 12, T-Tunnel Sites
CAS 12-06-02, Muckpile
CAU 559, T-Tunnel Compressor/Blower Pad
CAS 12-25-13, Oil-Stained Soil and Concrete
CAU 478, Area 12, T-Tunnel Ponds
CAS 12-23-01, Ponds (5), RAD Area
CAU 309, Area 12, Muckpiles
CAS 12-06-09, Muckpile
CAS 12-08-02, Contaminated Waste Dumps
CAS 12-28-01, I, J, and K-Tunnel
Access to this area is not permitted without
U.S. Government permission.
Before working in this area,
Contact Real Estate Services at 295-2528

g. Does the sign need to be replaced?

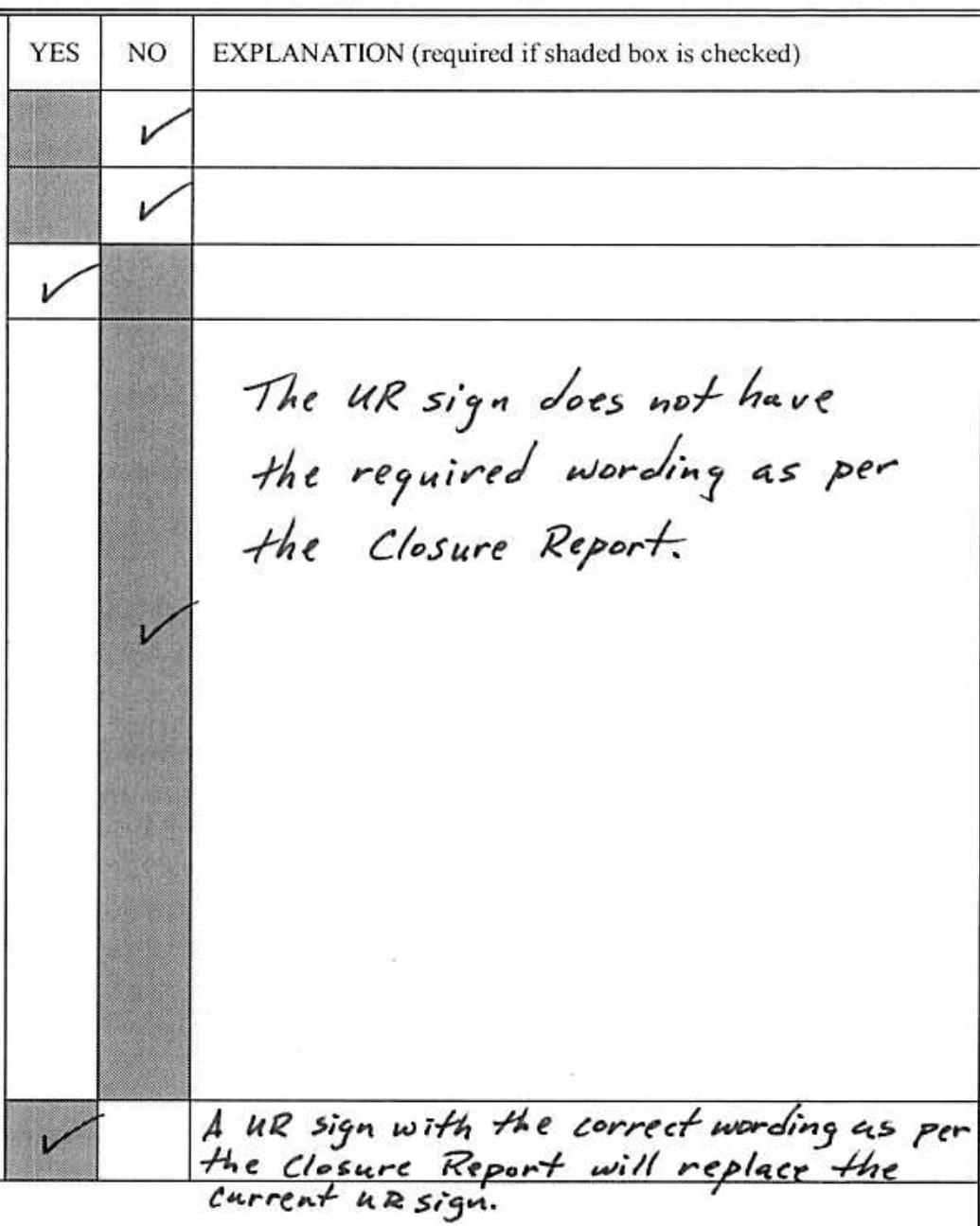

Photograph Instructions:

- Photographs should be taken to document maintenance/repair needs at the site. These will be used to plan maintenance/repair activities and are not intended for use in the post-closure annual report.

- Anomalous features or new features (such as changes in adjacent area land use) should be photographed.

- Other photographs are optional.

- A photograph log entry will be made for each photograph taken.

2. Photograph Documentation:

a. Have photographs been taken of the site?

If yes, how many photos were taken?

If yes, has a photographic log been prepared?

\section{E. FIELD CONCLUSIONS}

1. Are more frequent inspections required?

2. Are existing maintenance/repair actions satisfactory?

3. Are maintenance/repair actions necessary?

\begin{tabular}{|c|c|c|}
\hline YES & NO & EXPLANATION \\
\hline \multicolumn{3}{|c|}{2} \\
\hline YES & NO & EXPLANATION (required if shaded box is checked) \\
\hline & & $N / A$ \\
\hline & & If "yes", describe in Field conclusions/recommendations \\
\hline
\end{tabular}




\section{POST-CLOSURE INSPECTION CHECKLIST}

\section{CAU 478: AREA 12 T-TUNNEL PONDS - CAS 12-23-01, PONDS (5), RAD AREA}

\section{E. FIELD CONCLUSIONS (continued)}

4. Field conclusions/recommendations: The access gate is in excellent condition.

The mega UR sigh is visible and wording legible; however, the wording is not the same as per the Closure Report. The UR sign will need to be replaced.

\section{F. CERTIFICATION}

I have conducted an inspection of CAS 12-23-01, Ponds (5), RAD Area, in accordance with the procedures of the Post-Closure Plan as recorded on this checklist, attached sheets, field notes, photographs, and photograph logs.

\begin{tabular}{l|l} 
Chief Inspector's Signature: /s/ G Richardson & Date: $12 / 16 / 08$ \\
Printed Name: Glenn Kichardson & Title: Task Manager
\end{tabular}

\section{Required Attachments:}

- Field Notes (if any)

- Photos (or note File Location: S:INTS\ER Sharel Photos \CAU 4781 12-16-2008

Distribution: Original - Industrial Sites Project Manager

$$
\text { Copy - Task Manager }
$$

\section{G. VERIFICATION}

I have reviewed this checklist and attachments and have verified that it is complete.

Signature: /s/ R Poderis

Date: $1-20-09$

Printed Name: Thomas A. Thiele (or designee)

Distribution: Original - Task Manager 
THIS PAGE INTENTIONALLY LEFT BLANK 
CAU 482: AREA 15 U15A/E MUCKPILES AND PONDS 
THIS PAGE INTENTIONALLY LEFT BLANK 


\begin{tabular}{|c|c|c|c|}
\hline \multicolumn{4}{|c|}{ POST-CLOSURE INSPECTION CHECKLIST } \\
\hline \multicolumn{4}{|c|}{$\begin{array}{l}\text { CAU 482: AREA 15 U15A/E MUCKPILES AND PONDS } \\
\text { CAS 15-06-02, U15A MUCKPILE \& CAS 15-38-01, AREA 15 U15A/E PONDS }\end{array}$} \\
\hline \multirow{2}{*}{\multicolumn{2}{|c|}{$\begin{array}{l}\text { Inspection Date and Time: } 12 / 9 / 08 \quad 10: 15 \mathrm{AM} \\
\text { Date of Last Post-Closure Inspection: Noue - Ist inspection }\end{array}$}} & \multicolumn{2}{|c|}{ Reason for Inspection: Annual } \\
\hline & & \multicolumn{2}{|c|}{ Reason for Last Post-Closure Inspection: Ist Inspection } \\
\hline \multicolumn{4}{|c|}{ Responsible Entity: NSTec Environmental Restoration, Nevada Test Site, Mercury, Nevada } \\
\hline \multicolumn{4}{|c|}{ Responsible Facility Owner: Thomas A. Thiele, Project Manager, Industrial Sites, Environmental Restoration Project } \\
\hline \multicolumn{4}{|c|}{ Chief Inspector: Glenn Richardson / Reed Poderis Title: Task Manager } \\
\hline \multicolumn{2}{|l|}{ Assistant Inspector: Mike Floyd } & \multicolumn{2}{|c|}{ Title: Field Technical Lead } \\
\hline \multicolumn{4}{|c|}{$\begin{array}{l}\text { A. GENERAL INSTRUCTIONS } \\
\text { - Complete all checklist items. } \\
\text { - If a SHADED BOX is checked, provide detailed information regarding what was found and/or appropriate references } \\
\text { to other documents that have the information (e.g., Maintenance Order Form for CAS 25-01-07 dated 3/28/2008). } \\
\text { - All documentation must be legible and clear. }\end{array}$} \\
\hline B. PREPARATION (To be competed prior to site visit) & YES & NO & EXPLANATION (required if shaded box is checked) \\
\hline \multicolumn{4}{|l|}{ 1. Has the Post-Closure Plan been reviewed? } \\
\hline \multicolumn{4}{|l|}{ 2. Have the previous inspection reports been reviewed? } \\
\hline \multirow{2}{*}{$\begin{array}{l}\text { 3. Were anomalies or trends detected on previous inspections? } \\
\text { 4. Were maintenance or repairs performed since last inspection? }\end{array}$} & & & $N / A$ \\
\hline & & & $N / A$ \\
\hline \multicolumn{4}{|l|}{ C. SITE INSPECTION PREPARATION } \\
\hline \multicolumn{4}{|c|}{$\begin{array}{l}\text { Assemble the following, as needed, to conduct inspections: } \\
\text { a. Radio, pager, etc. } \\
\text { b. Camera, digital storage drive, and extra batteries } \\
\text { c. Previous Post-Closure Report, Inspection Checklists, repair records, and as-built plans } \\
\text { d. Tape measure } \\
\text { e. Other miscellaneous support equipment }\end{array}$} \\
\hline
\end{tabular}

\section{SITE INSPECTION}

- The site inspection to certify that markers and postings are in place, intact, and readable. Access to the use-restricted area is not permitted without U.S. Government permission. The checklist should be completed during the site inspection.

- If a shaded box is checked, add detailed comments to document the results of the site inspection. Information provided should be of sufficient detail to enable reconstruction of observations regarding field conditions. Information can take the form of written narrative, sketches, measurements, and annotated site maps, all of which should be placed on additional attachments (if needed) and cross-reference appropriately. Attach the additional pages and number all pages upon completion of the inspection. The completed checklist is part of the field record of the inspection.

- Field notes taken to assist in completion of this checklist will become part of the inspection record. No form is specified for field notes, and additional field notes are not required if the checklist and associated attachments adequately describe site conditions.

1. Site markers:

a. Is there damage to the $15-2 \mathrm{C}$ barricade gate?

b. Is the gate lock in place and functional?

\begin{tabular}{|c|c|l||} 
YES & NO & EXPLANATION (required if shaded box is checked) \\
\hline & $\checkmark$ & \\
\hline & & \\
\hline
\end{tabular}




\section{POST-CLOSURE INSPECTION CHECKLIST}

\section{CAU 482: AREA 15 U15A/E MUCKPILES AND PONDS}

\section{CAS 15-06-02, U15A MUCKPILE \& CAS 15-38-01, AREA 15 U15A/E PONDS}

1. Site markers (continued):

c. Have any posts been damaged or their anchoring weakened?

d. Is the use restriction sign posted at the $15-2 \mathrm{C}$ barricade?

e. Is the use restriction sign damaged or missing?

f. Is the use restriction sign legible?

g. Does the sign have the required wording (check wording on the sign):

WARNING
Radiologically Contaminated Areas
Beyond This Point
FFACO Site
CAU 482, Area 15, U15a/e Muckpiiles and Ponds
CAS 15-38-01, U15a/e Ponds
Drainage below CAS 15-06-02
Access to this area is not permitted without
U.S. Government permission.
Before working in this area,
Contact Real Estate Services at 295-2528

h. Does the sign need to be replaced?

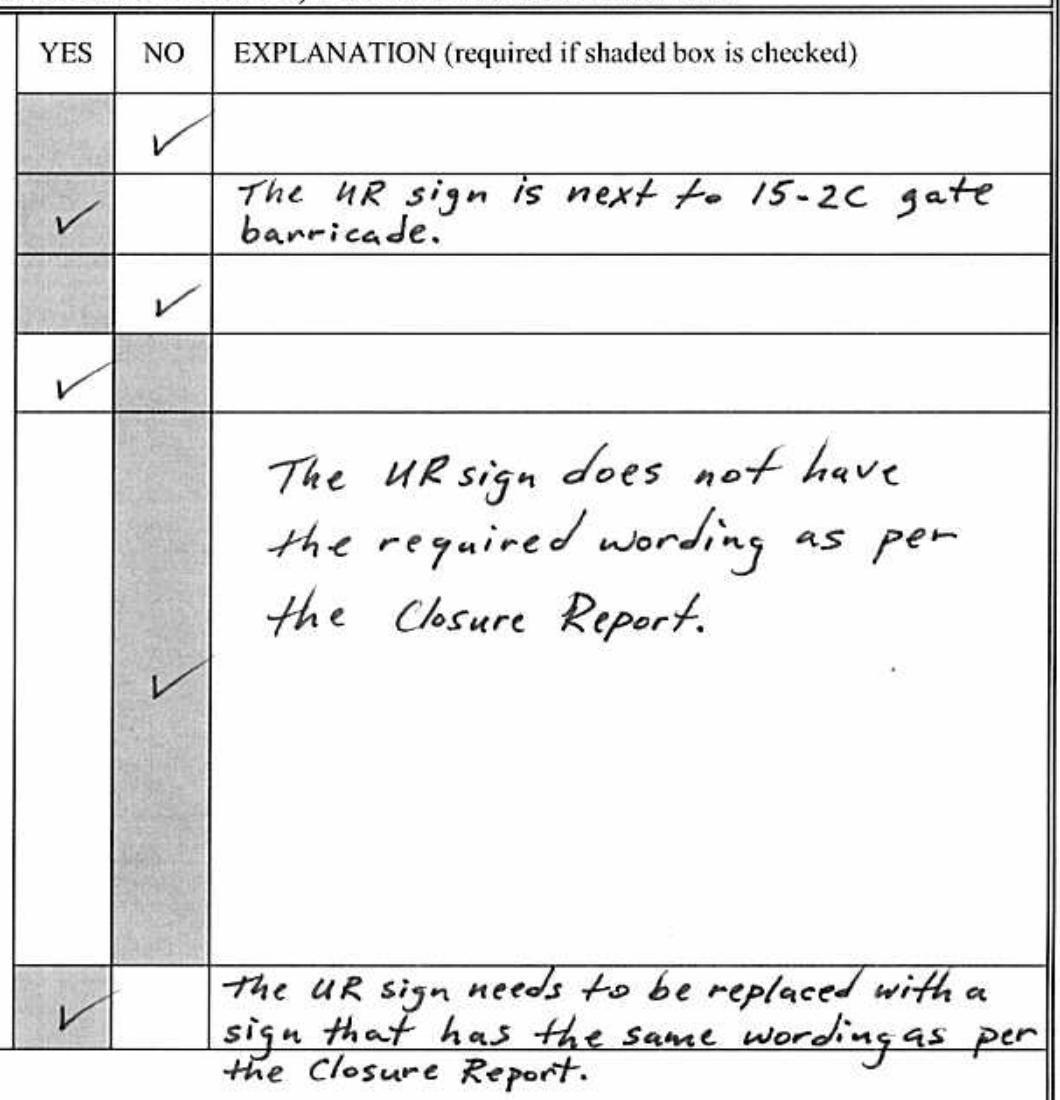

Photograph Instructions:

- Photographs should be taken to document maintenance/repair needs at the site. These will be used to plan maintenance/repair activities and are not intended for use in the post-closure annual report.

- Anomalous features or new features (such as changes in adjacent area land use) should be photographed.

- Other photographs are optional.

- A photograph log entry will be made for each photograph taken.

2. Photograph Documentation:

a. Have photographs been taken of the site?

If yes, how many photos were taken?

If yes, has a photographic log been prepared?

\section{E. FIELD CONCLUSIONS}

1. Are more frequent inspections required?

2. Are existing maintenance/repair actions satisfactory?

3. Are maintenance/repair actions necessary?

\begin{tabular}{|c|c|c|}
\hline YES & NO & EXPLANATION \\
\hline \multicolumn{2}{|c|}{2} & \\
\hline YES & NO & EXPLANATION (required if shaded box is checked) \\
\hline & & $N / A$ \\
\hline & & If "yes", describe below \\
\hline
\end{tabular}

4. Field conclusions/recommendations: The access gate is secured and well-maintained. The mega UR sign is legible and in excellent condition; but needs to be replaced because it does not have the same wording (text) as per the Closure Report. The site will reguire follow-up actions. 


\begin{tabular}{||c||}
\hline POST-CLOSURE INSPECTION CHECKLIST \\
\hline \hline CAU 482: AREA 15 U15A/E MUCKPILES AND PONDS \\
CAS 15-06-02, U15A MUCKPILE \& CAS 15-38-01, AREA 15 U15A/E PONDS \\
\hline \hline E. FIELD CONCLUSIONS (continued) \\
\hline 4. Field conclusions/recommendations (continued): \\
\hline
\end{tabular}

\section{F. CERTIFICATION}

I have conducted an inspection of CAS 15-06-01, U15a Muckpile, and CAS 15-38-01, Area 15 U15a/e Ponds, in accordance with the procedures of the PostClosure Plan as recorded on this checklist, attached sheefs, field notes, photographs, and photograph logs.

Chief Inspector's Signature: /s/ G Richardson

Printed Name: Gleun Kichardson

\section{Required Attachments:}

- Field Notes (if any)

- Photos (or note File Location: S:INTSIER Sharel Photos \CAu 482】 12 -9-2008

Distribution: Original - Industrial Sites Project Manager

$$
\text { Copy - Task Manager }
$$

\section{G. VERIFICATION}

I have reviewed this checklist and attachments and have verified that it is complete.

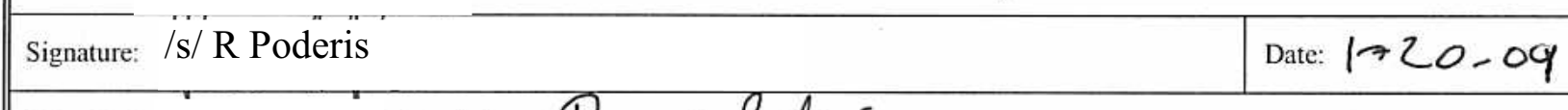

Printed Name: Thomas A. Thiele (or designee) Reed Poleñi

Distribution: Original - Task Manager 
THIS PAGE INTENTIONALLY LEFT BLANK 
CAU 528: POLYCHLORINATED BIPHENYLS CONTAMINATION 
THIS PAGE INTENTIONALLY LEFT BLANK 


\begin{tabular}{|c|c|c|c|}
\hline \multicolumn{4}{|c|}{ POST-CLOSURE INSPECTION CHECKLIST } \\
\hline \multicolumn{4}{|c|}{$\begin{array}{c}\text { CAU 528: POLYCHLORINATED BIPHENYLS CONTAMINATION } \\
\text { CAS 25-27-03, POLYCHLORINATED BIPHENYLS SURFACE CONTAMINATION } \\
\end{array}$} \\
\hline \multicolumn{2}{|l|}{ Inspection Date and Time: $12 / 09 / 08$ 3:05pm } & \multicolumn{2}{|c|}{ Reason for Inspection: Aw w on } \\
\hline \multicolumn{2}{|l|}{ Date of Last Post-Closure Inspection: $12 / 1 \S / 0\rangle$} & \multicolumn{2}{|c|}{ Reason for Last Post-Closure Inspection: Hwwo } \\
\hline \multicolumn{4}{|c|}{ Responsible Entity: NSTec Environmental Restoration, Nevada Test Site, Mercury, Nevada } \\
\hline \multicolumn{4}{|c|}{ Responsible Facility Owner: Thomas A. Thiele, Project Manager, Industrial Sites, Environmental Restoration Project } \\
\hline \multicolumn{2}{|l|}{ Chief Inspector: } & Title: & Task riswager \\
\hline \multicolumn{2}{|l|}{ Assistant Inspector: $D c c_{C+1}($ Erre } & Title: & Sr. Scisentisi \\
\hline \multicolumn{4}{|c|}{$\begin{array}{l}\text { A. GENERAL INSTRUCTIONS } \\
\text { 1. All checklist items must be completed and detailed comments made to document the results of the site inspection. The completed checklist is } \\
\text { part of the field record of the inspection. Additional pages should be used as necessary to ensure that a complete record is made. Attach the } \\
\text { additional pages and number all pages upon completion of the inspection. } \\
\text { 2. Any checklist line item marked by an inspector in a SHADED BOX must be fully explained or an appropriate reference to previous reports } \\
\text { provided. The purpose of this requirement is to provide a written explanation of inspector observations and the inspector's rationale for } \\
\text { conclusions and recommendations. Explanations are to be placed on additional attachments and cross-referenced appropriately. } \\
\text { Explanations, in addition to narrative, will take the form of sketches, measurements, and annotated site maps. } \\
\text { 3. The site inspection is a walking inspection of the entire site including the perimeter and sufficient transects to be able to inspect the entire } \\
\text { surface and all features specifically described in this checklist. } \\
\text { 4. Field notes taken to assist in completion of this checklist will become part of the inspection record. No form is specified for field notes; } \\
\text { however, they must be legible and in sufficient detail to enable review by succeeding inspectors and the responsible agency. } \\
\text { 5. This unit will be inspected annually with formal reporting to the Nevada Division of Environmental Protection to be done annually. The } \\
\text { annual letter report will include a summary with this inspection checklist attached. }\end{array}$} \\
\hline B. PREPARATION (To be competed prior to site visit) & YES & NO & EXPLANATION (required if shaded box is checked) \\
\hline \multicolumn{4}{|l|}{ 1. Has the Post-Closure Plan been reviewed? } \\
\hline \multicolumn{4}{|l|}{ 2. Have the previous inspection reports been reviewed? } \\
\hline \multicolumn{4}{|l|}{ 3. Were anomalies or trends detected on previous inspections? } \\
\hline \multirow{2}{*}{$\begin{array}{l}\text { 4. Were maintenance or repairs performed since last inspection? } \\
\text { a. If yes, obtain a copy of maintenance records and attach to } \\
\text { checklist. }\end{array}$} & & & $\therefore$ \\
\hline & & & NA \\
\hline \multicolumn{4}{|c|}{ C. SITE INSPECTION PREPARATION } \\
\hline \multicolumn{4}{|c|}{$\begin{array}{l}\text { Assemble the following, as needed, to conduct inspections: } \\
\text { a. Radio, pager, etc. } \\
\text { b. Previous letter report, inspection checklists, repair records, and as-built plans } \\
\text { c. Other miscellaneous support equipment } \\
\end{array}$} \\
\hline \multicolumn{4}{|l|}{ D. SITE INSPECTION } \\
\hline \multirow{5}{*}{$\begin{array}{l}\text { 1. Site markers: } \\
\text { a. Have any posts been damaged or their anchoring weakened }\end{array}$} & YES & NO & EXPLANATION (required if shaded box is checked) \\
\hline & & $\sim$ & \\
\hline & & & 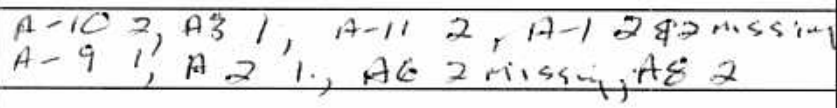 \\
\hline & & & \\
\hline & & & \\
\hline
\end{tabular}




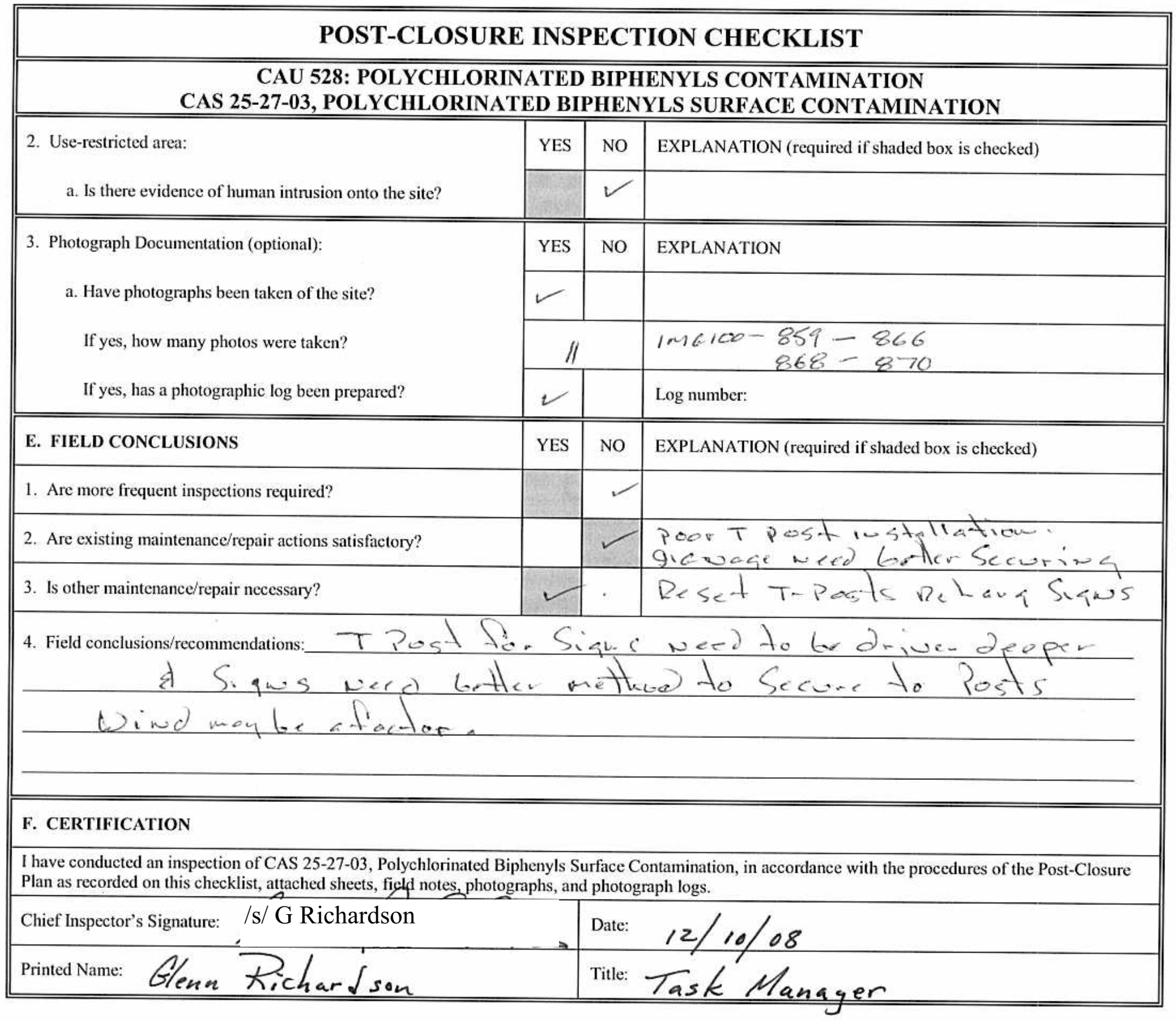

Attachments (check if attached):

Maintenance records 
CAU 529: AREA 25 CONTAMINATED MATERIALS 
THIS PAGE INTENTIONALLY LEFT BLANK 


\begin{tabular}{|c|c|}
\hline \multicolumn{2}{|c|}{ POST-CLOSURE INSPECTION CHECKLIST } \\
\hline \multicolumn{2}{|c|}{$\begin{array}{c}\text { CAU 529: AREA 25 CONTAMINATED MATERIALS } \\
\text { CAS 25-23-17, CONTAMINATED WASH, PARCELS E \& H } \\
\end{array}$} \\
\hline Inspection Date and Time: $12 / 10 \mathrm{~K} 8 \mathrm{~g} 10: 34 \mathrm{Am}$ & Reason for Inspection: Awu心a \\
\hline Date of Last Post-Closure Inspection: $1 \gg / 13 / 07$ & Reason for Last Post-Closure Inspection: Aw $\cup \cup \times$ ) \\
\hline
\end{tabular}

Responsible Entity: NSTec Environmental Restoration, Nevada Test Site, Mercury, Nevada

Responsible Facility Owner: Thomas A. Thiele, Project Manager, Industrial Sites, Environmental Restoration Project

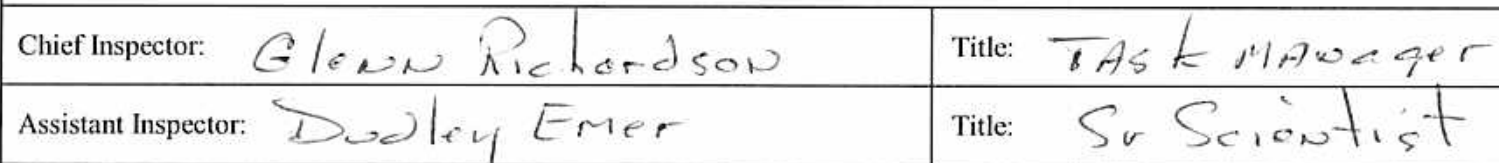

A. GENERAL INSTRUCTIONS

1. All checklist items must be completed and detailed comments made to document the results of the site inspection. The completed checklist is part of the field record of the inspection. Additional pages should be used as necessary to ensure that a complete record is made. Attach the additional pages and number all pages upon completion of the inspection.

2. Any checklist line item marked by an inspector in a SHADED BOX must be fully explained or an appropriate reference to previous reports provided. The purpose of this requirement is to provide a written explanation of inspector observations and the inspector's rationale for conclusions and recommendations. Explanations are to be placed on additional attachments and cross-referenced appropriately. Explanations, in addition to narrative, will take the form of sketches, measurements, and annotated site maps.

3. The site inspection is a walking inspection of the entire site including the perimeter and sufficient transects to be able to inspect the entire surface and all features specifically described in this checklist.

4. Field notes taken to assist in completion of this checklist will become part of the inspection record. No form is specified for field notes; however, they must be legible and in sufficient detail to enable review by succeeding inspectors and the responsible agency.

5. This unit will be inspected annually with formal reporting to the Nevada Division of Environmental Protection to be done annually. The annual letter report will include a summary with this inspection checklist attached.

B. PREPARATION (To be competed prior to site visit)

1. Has the Post-Closure Plan been reviewed?

2. Have the previous inspection reports been reviewed?

3. Were anomalies or trends detected on previous inspections?

4. Were maintenance or repairs performed since last inspection?

\begin{tabular}{|c|c|c|}
\hline YES & NO & EXPLANATION (required if shaded box is checked) \\
\hline & & \\
\hline & & \\
\hline & & Isigu dowe in parce I 11 . \\
\hline & & $\begin{array}{l}\text { Re-ius tellid } 3 \text { Sigos } * \text { Repaind } \\
\text { Rope fences } 6 / 2 y / \text { of }\end{array}$ \\
\hline
\end{tabular}

\section{SITE INSPECTION PREPARATION}

Assemble the following, as needed, to conduct inspections:

a. Radio, pager, etc.

b. Previous letter report, inspection checklists, repair records, and as-built plans

c. Other miscellaneous support equipment

\section{SITE INSPECTION}

1. Site markers (Parcel E):

a. Have any posts been damaged or their anchoring weakened?

b. Are any of the use restriction signs damaged or missing?

c. Are all use restriction signs legible?

d. How many signs need to be replaced?

2. Use-restricted area (Parcel E):

a. Is there evidence of human intrusion onto the site?

\begin{tabular}{|l|l|l||}
\hline YES & NO & EXPLANATION (required if shaded box is checked) \\
\hline & & \\
\hline & & \\
\hline & & \\
\hline \multicolumn{2}{|c|}{} & \\
\hline YES & NO & EXPLANATION (required if shaded box is checked) \\
\hline & & \\
\hline
\end{tabular}




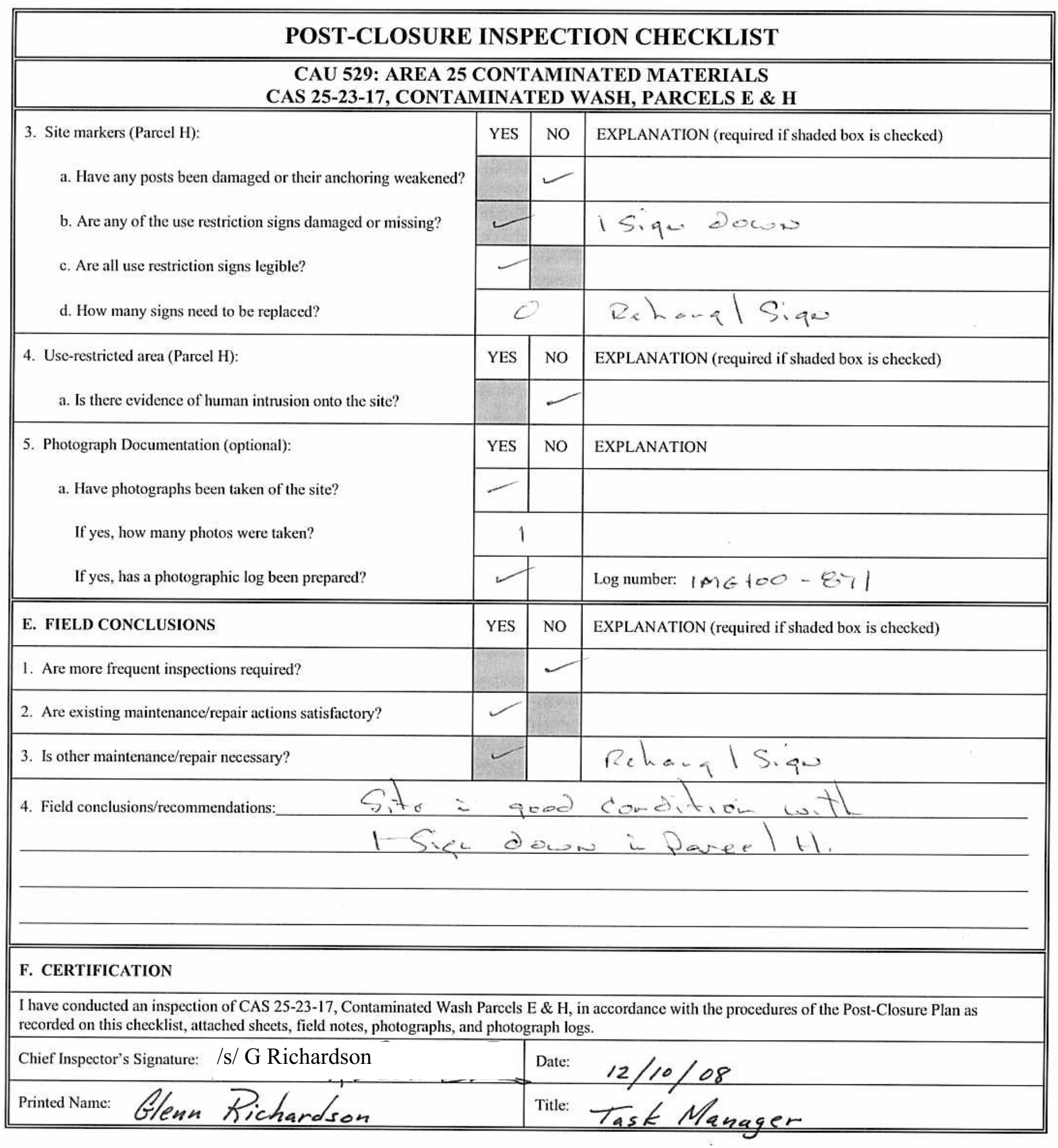


CAU 542: DISPOSAL HOLES 
THIS PAGE INTENTIONALLY LEFT BLANK 


\section{POST-CLOSURE INSPECTION CHECKLIST}

\section{CAU 542: DISPOSAL HOLES - CAS 03-20-07, UD-3A DISPOSAL HOLE}

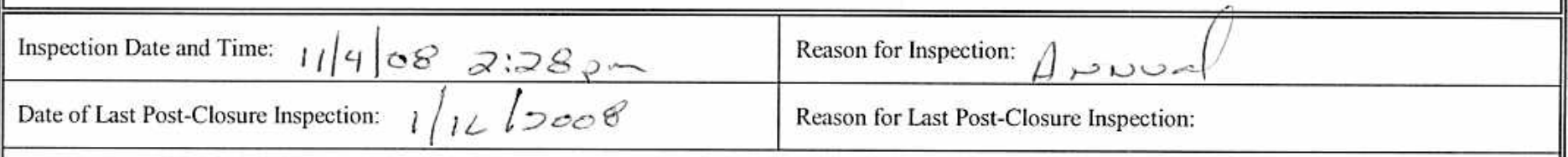

Responsible Entity: NSTec Environmental Restoration, Nevada Test Site, Mercury, Nevada

Responsible Facility Owner: Thomas A. Thiele, Project Manager, Industrial Sites, Environmental Restoration Project

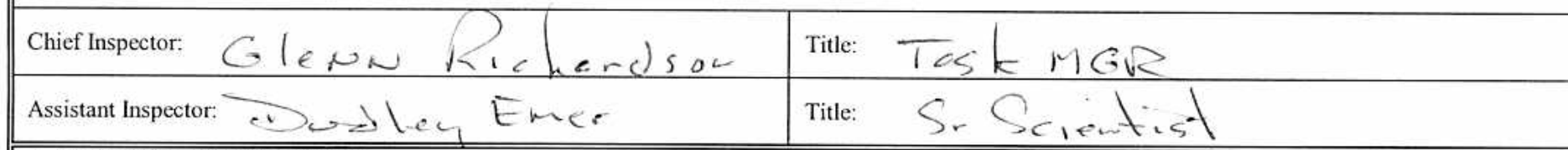

\section{A. GENERAL INSTRUCTIONS}

1. All checklist items must be completed and detailed comments made to document the results of the site inspection. The completed checklist is part of the field record of the inspection. Additional pages should be used as necessary to ensure that a complete record is made. Attach the additional pages and number all pages upon completion of the inspection.

2. Any checklist line item marked by an inspector in a SHADED BOX must be fully explained or an appropriate reference to previous reports provided. The purpose of this requirement is to provide a written explanation of inspector observations and the inspector's rationale for conclusions and recommendations. Explanations are to be placed on additional attachments and cross-referenced appropriately. Explanations, in addition to narrative, will take the form of sketches, measurements, and annotated site maps.

3. The site inspection is a walking inspection of the entire site including the perimeter and sufficient transects to be able to inspect the entire surface and all features specifically described in this checklist.

4. Field notes taken to assist in completion of this checklist will become part of the inspection record. No form is specified for field notes; however, they must be legible and in sufficient detail to enable review by succeeding inspectors and the responsible agency.

5. This unit will be inspected annually with formal reporting to the Nevada Division of Environmental Protection to be done annually. The annual letter report will include a summary with this inspection checklist attached.

\begin{tabular}{|c|c|c|c|}
\hline B. PREPARATION (To be competed prior to site visit) & YES & NO & EXPLANATION (required if shaded box is checked) \\
\hline 1. Has the Post-Closure Plan been reviewed? & $\checkmark$ & & \\
\hline 2. Have the previous inspection reports been reviewed? & & & \\
\hline 3. Were anomalies or trends detected on previous inspections? & & 2 & \\
\hline 4. Were maintenance or repairs performed since last inspection? & & & e \\
\hline
\end{tabular}

\section{SITE INSPECTION PREPARATION}

Assemble the following, as needed, to conduct inspections:

a. Radio, pager, etc.

b. Previous letter report, inspection checklists, repair records, and as-built plans

c. Other miscellaneous support equipment

\section{SITE INSPECTION}

\section{Site markers:}

a. Have any posts been damaged or their anchoring weakened?

b. Are any of the 4 use restriction signs damaged or missing?

c. Are all use restriction signs legible?

d. How many signs need to be replaced?

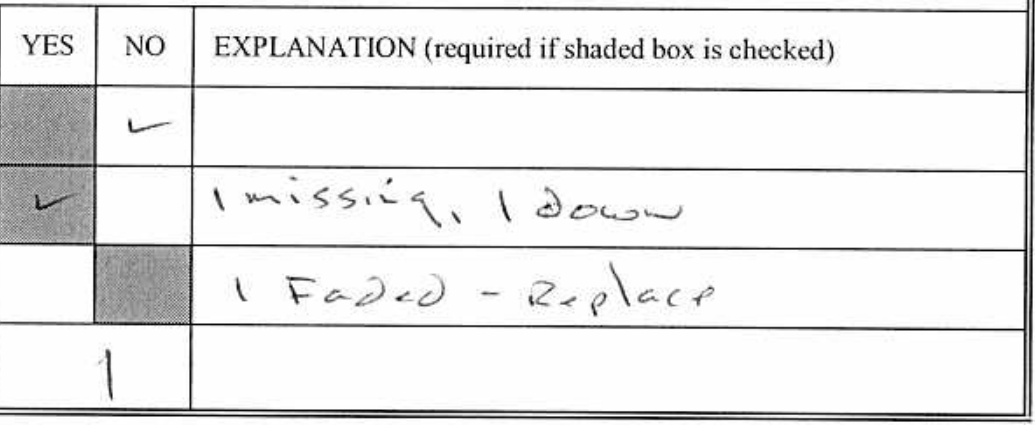




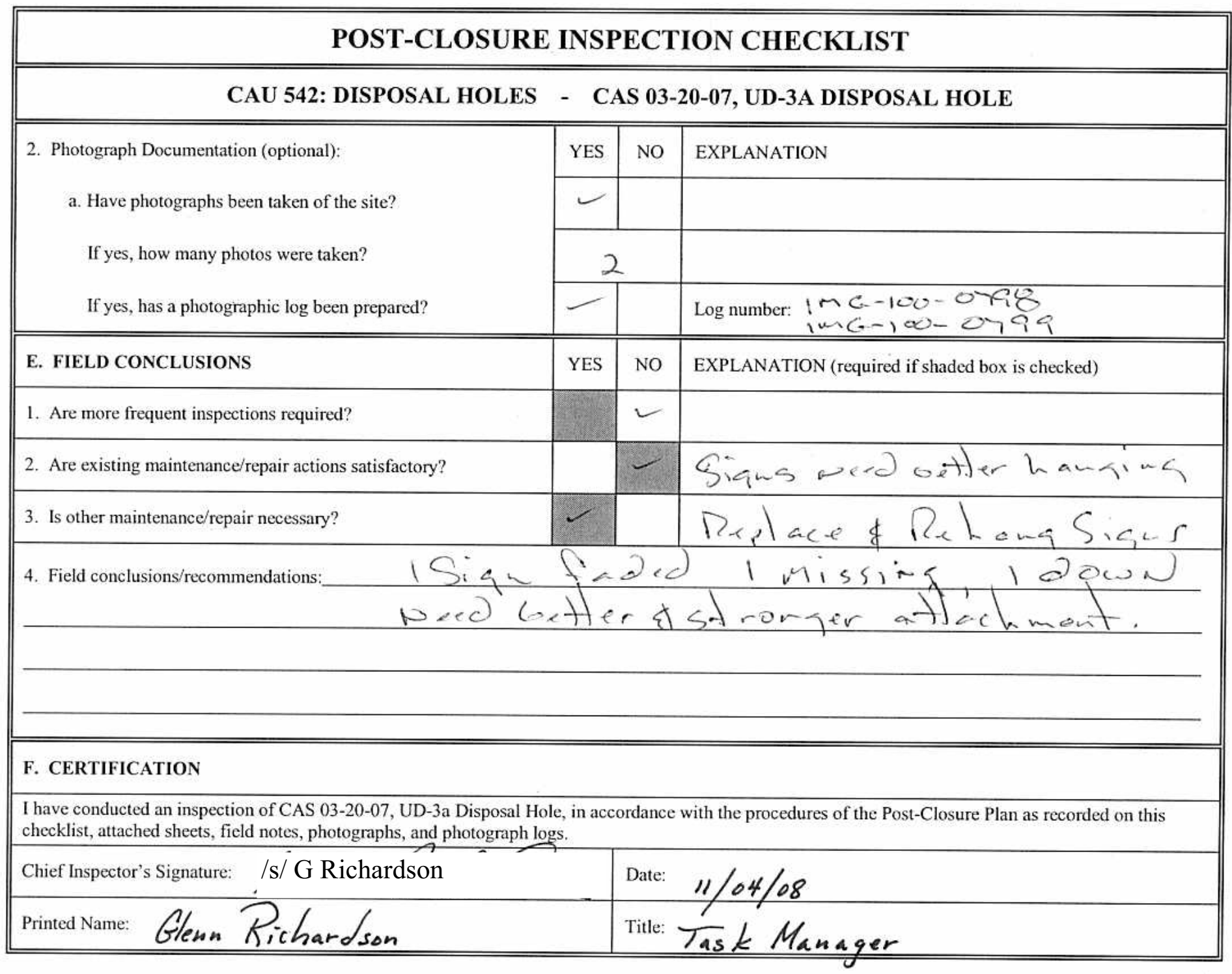




\section{POST-CLOSURE INSPECTION CHECKLIST}

\section{CAU 542: DISPOSAL HOLES - CAS 03-20-09, UD-3B DISPOSAL HOLE}

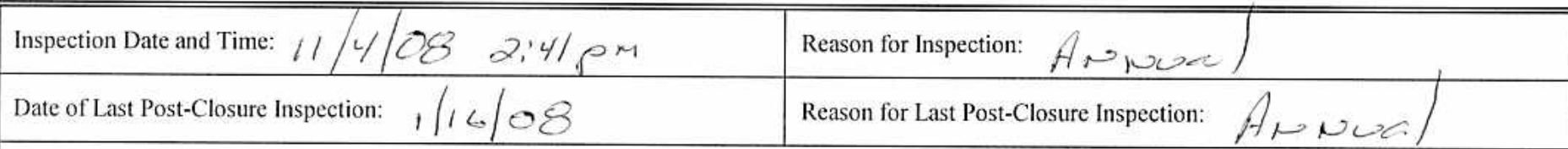

Responsible Entity: NSTec Environmental Restoration, Nevada Test Site, Mercury, Nevada

Responsible Facility Owner: Thomas A. Thiele, Project Manager, Industrial Sites, Environmental Restoration Project

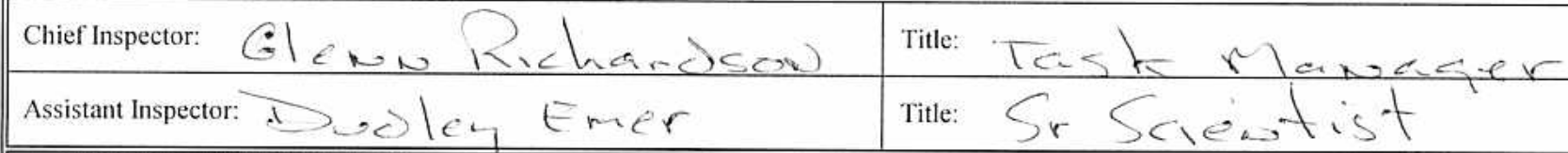

\section{A. GENERAL INSTRUCTIONS}

1. All checklist items must be completed and detailed comments made to document the results of the site inspection. The completed checklist is part of the field record of the inspection. Additional pages should be used as necessary to ensure that a complete record is made. Attach the additional pages and number all pages upon completion of the inspection.

2. Any checklist line item marked by an inspector in a SHADED BOX must be fully explained or an appropriate reference to previous reports provided. The purpose of this requirement is to provide a written explanation of inspector observations and the inspector's rationale for conclusions and recommendations. Explanations are to be placed on additional attachments and cross-referenced appropriately. Explanations, in addition to narrative, will take the form of sketches, measurements, and annotated site maps.

3. The site inspection is a walking inspection of the entire site including the perimeter and sufficient transects to be able to inspect the entire surface and all features specifically described in this checklist.

4. Field notes taken to assist in completion of this checklist will become part of the inspection record. No form is specified for field notes; however, they must be legible and in sufficient detail to enable review by succeeding inspectors and the responsible agency.

5. This unit will be inspected annually with formal reporting to the Nevada Division of Environmental Protection to be done annually. The annual letter report will include a summary with this inspection checklist attached.

\begin{tabular}{|c|c|c|c|}
\hline B. PREPARATION (To be competed prior to site visit) & YES & NO & EXPLANATION (required if shaded box is checked) \\
\hline 1. Has the Post-Closure Plan been reviewed? & & & \\
\hline 2. Have the previous inspection reports been reviewed? & & & \\
\hline 3. Were anomalies or trends detected on previous inspections? & & & \\
\hline 4. Were maintenance or repairs performed since last inspection? & & & \\
\hline
\end{tabular}

\section{SITE INSPECTION PREPARATION}

Assemble the following, as needed, to conduct inspections:

a. Radio, pager, etc.

b. Previous letter report, inspection checklists, repair records, and as-built plans

c. Other miscellaneous support equipment

\section{SITE INSPECTION}

1. Site markers:

a. Have any posts been damaged or their anchoring weakened?

b. Are any of the 4 use restriction signs damaged or missing?

c. Are all use restriction signs legible?

d. How many signs need to be replaced?

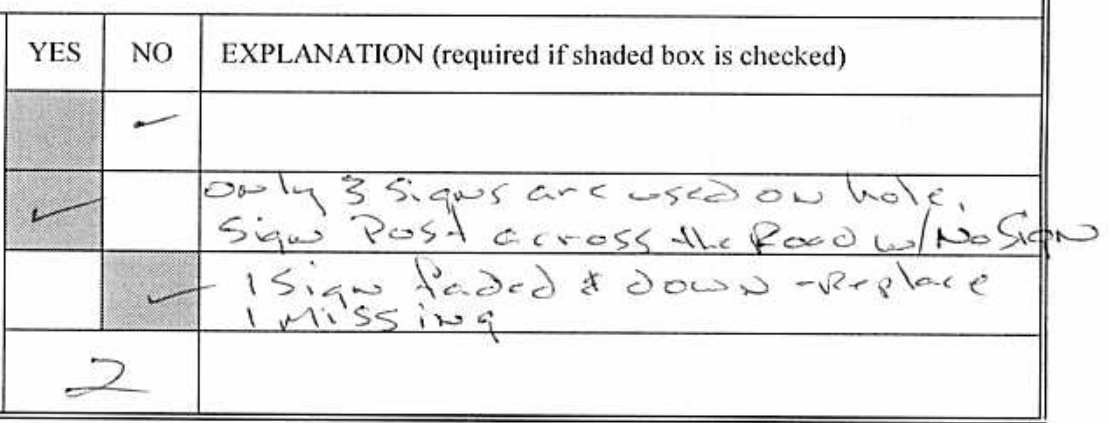




\section{POST-CLOSURE INSPECTION CHECKLIST}

\section{CAU 542: DISPOSAL HOLES - CAS 03-20-09, UD-3B DISPOSAL HOLE}

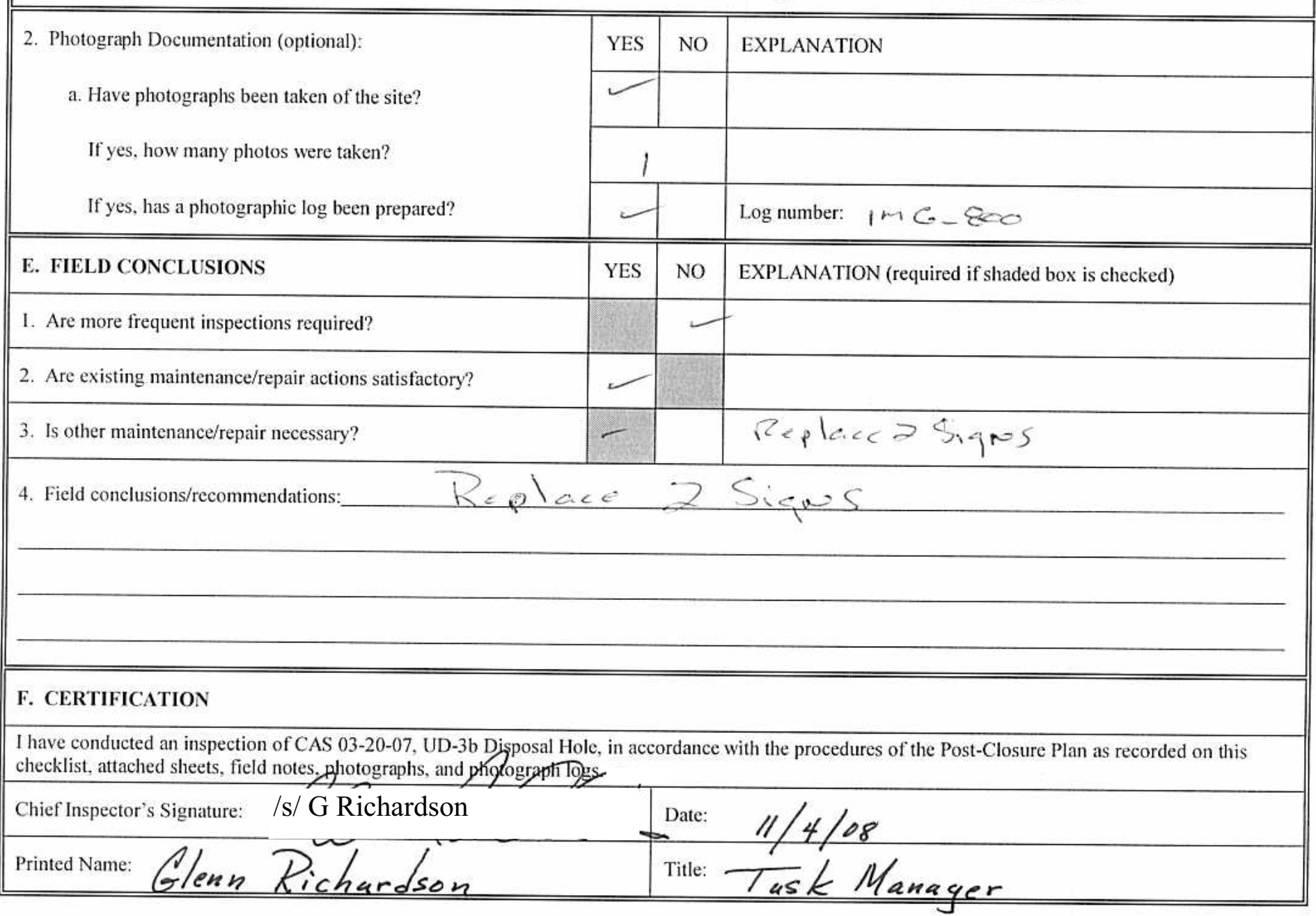




\section{POST-CLOSURE INSPECTION CHECKLIST}

\section{CAU 542: DISPOSAL HOLES - CAS 03-20-10, UD-3C DISPOSAL HOLE}

\begin{tabular}{|c|c|}
\hline Inspection Date and Time: $11 / 40 \& \quad 15: \infty 0$ & Reason for Inspection: \\
\hline Date of Last Post-Closure Inspection: $1 / 16 / 2008 ?$ & Reason for Last Post-Closure Inspection: \\
\hline
\end{tabular}

Responsible Entity: NSTec Environmental Restoration, Nevada Test Site, Mercury, Nevada

Responsible Facility Owner: Thomas A. Thiele, Project Manager, Industrial Sites, Environmental Restoration Project

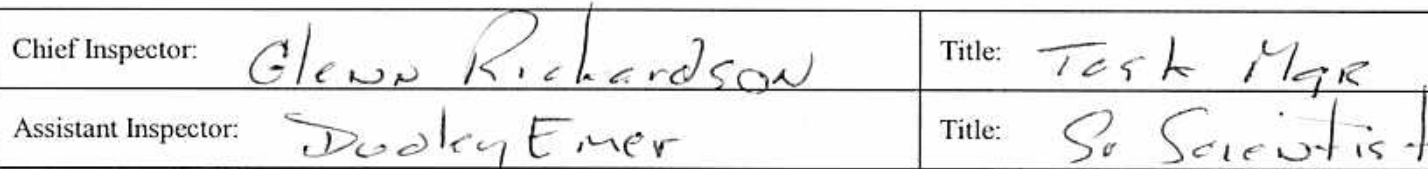

A. GENERAL INSTRUCTIONS

1. All checklist items must be completed and detailed comments made to document the results of the site inspection. The completed checklist is part of the field record of the inspection. Additional pages should be used as necessary to ensure that a complete record is made. Attach the additional pages and number all pages upon completion of the inspection.

2. Any checklist line item marked by an inspector in a SHADED BOX must be fully explained or an appropriate reference to previous reports provided. The purpose of this requirement is to provide a written explanation of inspector observations and the inspector's rationale for conclusions and recommendations. Explanations are to be placed on additional attachments and cross-referenced appropriately. Explanations, in addition to narrative, will take the form of sketches, measurements, and annotated site maps.

3. The site inspection is a walking inspection of the entire site including the perimeter and sufficient transects to be able to inspect the entire surface and all features specifically described in this checklist.

4. Field notes taken to assist in completion of this checklist will become part of the inspection record. No form is specified for field notes; however, they must be legible and in sufficient detail to enable review by succeeding inspectors and the responsible agency.

5. This unit will be inspected annually with formal reporting to the Nevada Division of Environmental Protection to be done annually. The annual letter report will include a summary with this inspection checklist attached.

\begin{tabular}{|c|c|c|c|}
\hline B. PREPARATION (To be competed prior to site visit) & YES & NO & EXPLANATION (required if shaded box is checked) \\
\hline 1. Has the Post-Closure Plan been reviewed? & $\sim$ & & \\
\hline 2. Have the previous inspection reports been reviewed? & c & & \\
\hline 3. Were anomalies or trends detected on previous inspections? & - & & 1 loose Sigu Repared soo日 \\
\hline 4. Were maintenance or repairs performed since last inspection? & $L$ & & 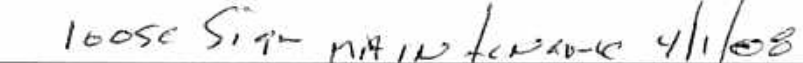 \\
\hline
\end{tabular}

\section{SITE INSPECTION PREPARATION}

Assemble the following, as needed, to conduct inspections:

a. Radio, pager, etc.

b. Previous letter report, inspection checklists, repair records, and as-built plans

c. Other miscellaneous support equipment

\section{SITE INSPECTION}

1. Site markers:

a. Have any posts been damaged or their anchoring weakened?

b. Are any of the 4 use restriction signs damaged or missing?

c. Are all use restriction signs legible?

d. How many signs need to be replaced?

\begin{tabular}{|l|l|l||}
\hline YES & NO & EXPLANATION (required if shaded box is checked) \\
\hline & & \\
\hline & & $2.4 i \sin 5$ \\
\hline & & \\
\hline
\end{tabular}




\section{POST-CLOSURE INSPECTION CHECKLIST}

\section{CAU 542: DISPOSAL HOLES - CAS 03-20-10, UD-3C DISPOSAL HOLE}

2. Photograph Documentation (optional):

a. Have photographs been taken of the site?

If yes, how many photos were taken?

If yes, has a photographic log been prepared?

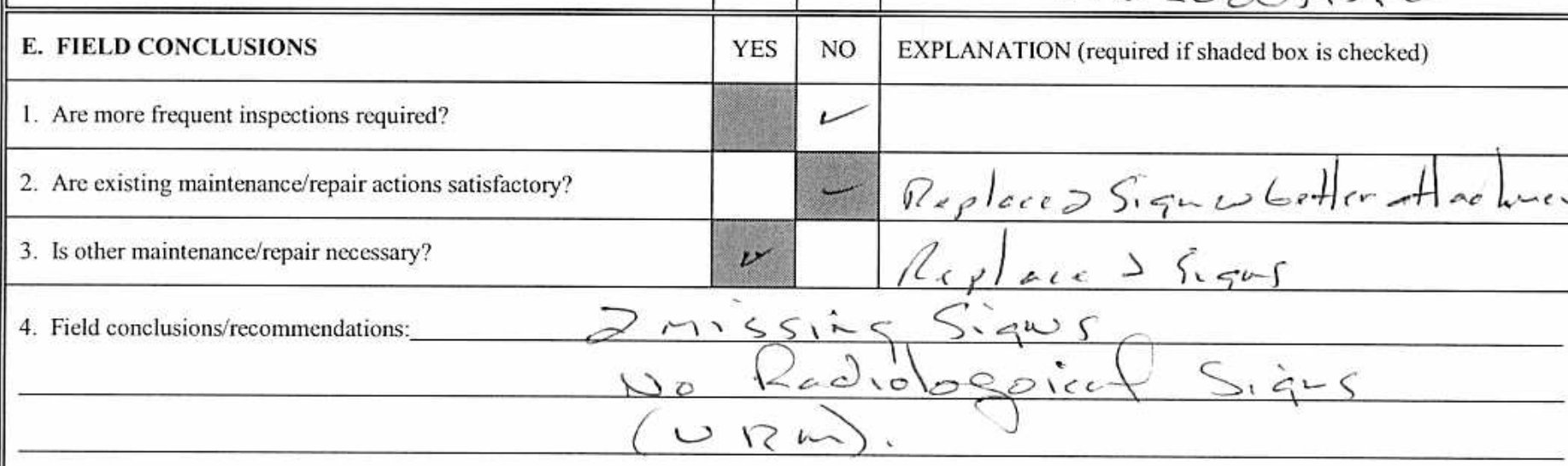

\section{F. CERTIFICATION}

I have conducted an inspection of CAS 03-20-07, UD-3c Disposal Hole, in accordance with the procedures of the Post-Closure Plan as recorded on this checklist, attached sheets, field notes, photographs, and photograph logs.

Chief Inspector's Signature: /s/ G Richardson

Printed Name: Geun Fichardson

Date: $11 / 04 / 08$

Title: Task Manager 


\section{POST-CLOSURE INSPECTION CHECKLIST}

\section{CAU 542: DISPOSAL HOLES - CAS 03-20-11, UD-3D DISPOSAL HOLE}

\begin{tabular}{||l|l|}
\hline \hline Inspection Date and Time, $/ 4 / 68$ & Reason for Inspection: \\
\hline Date of Last Post-Closure Inspection: $1 / 16 / 08000$
\end{tabular}

Responsible Entity: NSTec Environmental Restoration, Nevada Test Site, Mercury, Nevada

Responsible Facility Owner: Thomas A. Thiele, Project Manager, Industrial Sites, Environmental Restoration Project

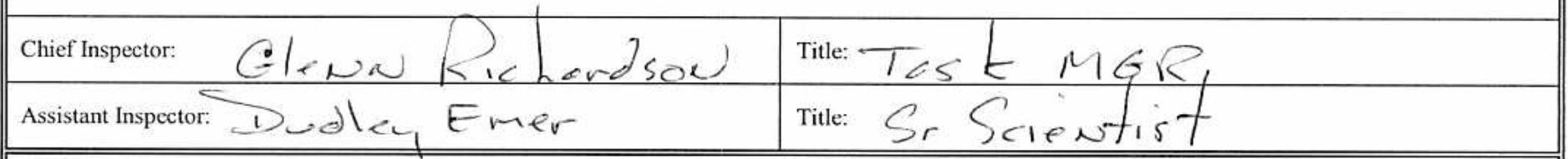

\section{A. GENERAL INSTRUCTIONS}

1. All checklist items must be completed and detailed comments made to document the results of the site inspection. The completed checklist is part of the field record of the inspection. Additional pages should be used as necessary to ensure that a complete record is made. Attach the additional pages and number all pages upon completion of the inspection.

2. Any checklist line item marked by an inspector in a SHADED BOX must be fully explained or an appropriate reference to previous reports provided. The purpose of this requirement is to provide a written explanation of inspector observations and the inspector's rationale for conclusions and recommendations. Explanations are to be placed on additional attachments and cross-referenced appropriately. Explanations, in addition to narrative, will take the form of sketches, measurements, and annotated site maps.

3. The site inspection is a walking inspection of the entire site including the perimeter and sufficient transects to be able to inspect the entire surface and all features specifically described in this checklist.

4. Field notes taken to assist in completion of this checklist will become part of the inspection record. No form is specified for field notes; however, they must be legible and in sufficient detail to enable review by succeeding inspectors and the responsible agency.

5. This unit will be inspected annually with formal reporting to the Nevada Division of Environmental Protection to be done annually. The annual letter report will include a summary with this inspection checklist attached.

\begin{tabular}{|l|l|l|l|}
\hline B. PREPARATION (To be competed prior to site visit) & YES & NO & EXPLANATION (required if shaded box is checked) \\
\hline 1. Has the Post-Closure Plan been reviewed? & & & \\
2. Have the previous inspection reports been reviewed? & & & \\
3. Were anomalies or trends detected on previous inspections? & & & \\
\cline { 2 - 4 } 4. Were maintenance or repairs performed since last inspection? & & & \\
\hline \hline
\end{tabular}

\section{SITE INSPECTION PREPARATION}

Assemble the following, as needed, to conduct inspections:

a. Radio, pager, etc.

b. Previous letter report, inspection checklists, repair records, and as-built plans

c. Other miscellaneous support equipment

\section{SITE INSPECTION}

1. Site markers:

a. Have any posts been damaged or their anchoring weakened?

b. Are any of the 4 use restriction signs damaged or missing?

c. Are all use restriction signs legible?

d. How many signs need to be replaced?

\begin{tabular}{|l|l|l||}
\hline YES & NO & EXPLANATION (required if shaded box is checked) \\
\hline & & \\
\hline 4 & & Down Si iws \\
\hline 0 & 2 \\
\hline
\end{tabular}




\section{POST-CLOSURE INSPECTION CHECKLIST}

CAU 542: DISPOSAL HOLES - CAS 03-20-11, UD-3D DISPOSAL HOLE

\begin{tabular}{|c|c|c|c|}
\hline \multirow{2}{*}{$\begin{array}{l}\text { 2. Photograph Documentation (optional): } \\
\text { a. Have photographs been taken of the site? }\end{array}$} & YES & $\mathrm{NO}$ & EXPLANATION \\
\hline & & & \\
\hline If yes, how many photos were taken? & & & \\
\hline If yes, has a photographic log been prepared? & & & Log number: , $\mathrm{CG}=0804 . \mathrm{J}_{1} \mathrm{C}$ \\
\hline E. FIELD CONCLUSIONS & YES & NO & EXPLANATION (required if shaded box is checked) \\
\hline 1. Are more frequent inspections required? & & & \\
\hline 2. Are existing maintenance/repair actions satisfactory? & & & 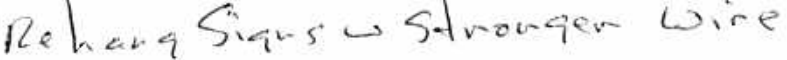 \\
\hline 3. Is other maintenance/repair necessary? & & & \\
\hline 4. Field conclusions/recommendations: & & & $c h$ \\
\hline
\end{tabular}

\section{F. CERTIFICATION}

I have conducted an inspection of CAS 03-20-11, UD-3d Disposal Hole, in accordance with the procedures of the Post-Closure Plan as recorded on this checklist, attached sheets, field notes, photographs, and photograph loger

Chief Inspector's Signature: /s/ G Richardson

Printed Name: Glenn Fichardson

Date:

$11 / 04 / 08$

Title: Task Manager 


\section{POST-CLOSURE INSPECTION CHECKLIST}

\section{CAU 542: DISPOSAL HOLES - CAS 06-20-03, UD-6 AND UD-6S DISPOSAL HOLES}

\begin{tabular}{||l|l|}
\hline \hline Inspection Date and Time: $11 / 04 / 08 \quad 1: 58 \mathrm{PM}$ & Reason for Inspection: An nual \\
\hline Date of Last Post-Closure Inspection: $1 / 16 / 08$ & Reason for Last Post-Closure Inspection: Ann $\mathrm{na} /$ \\
\hline
\end{tabular}

Responsible Entity: NSTec Environmental Restoration, Nevada Test Site, Mercury, Nevada

Responsible Facility Owner: Thomas A. Thiele, Project Manager, Industrial Sites, Environmental Restoration Project

\begin{tabular}{l|l}
\hline chief Inspector: Glenn Richardson & Title: Task Manager \\
\hline Assistant Inspector: Dudley Emer & Title: Sr. Scientist
\end{tabular}

A. GENERAL INSTRUCTIONS

1. All checklist items must be completed and detailed comments made to document the results of the site inspection. The completed checklist is part of the field record of the inspection. Additional pages should be used as necessary to ensure that a complete record is made. Attach the additional pages and number all pages upon completion of the inspection.

2. Any checklist line item marked by an inspector in a SHADED BOX must be fully explained or an appropriate reference to previous reports provided. The purpose of this requirement is to provide a written explanation of inspector observations and the inspector's rationale for conclusions and recommendations. Explanations are to be placed on additional attachments and cross-referenced appropriately. Explanations, in addition to narrative, will take the form of sketches, measurements, and annotated site maps.

3. The site inspection is a walking inspection of the entire site including the perimeter and sufficient transects to be able to inspect the entire surface and all features specifically described in this checklist.

4. Field notes taken to assist in completion of this checklist will become part of the inspection record. No form is specified for field notes; however, they must be legible and in sufficient detail to enable review by succeeding inspectors and the responsible agency.

5. This unit will be inspected annually with formal reporting to the Nevada Division of Environmental Protection to be done annually. The annual letter report will include a summary with this inspection checklist attached.

\begin{tabular}{|c|c|c|c|}
\hline B. PREPARATION (To be competed prior to site visit) & YES & NO & EXPLANATION (required if shaded box is checked) \\
\hline 1. Has the Post-Closure Plan been reviewed? & & & \\
\hline 2. Have the previous inspection reports been reviewed? & & & \\
\hline 3. Were anomalies or trends detected on previous inspections? & & & \\
\hline 4.Were maintenance or repairs performed since last inspection? & & & \\
\hline
\end{tabular}

\section{SITE INSPECTION PREPARATION}

Assemble the following, as needed, to conduct inspections:

a. Radio, pager, etc.

b. Previous letter report, inspection checklists, repair records, and as-built plans

c. Other miscellaneous support equipment

\section{SITE INSPECTION}

1. Site markers:

a. Have any posts been damaged or their anchoring weakened?

b. Are any of the 4 use restriction signs damaged or missing?

c. Are all use restriction signs legible?

d. How many signs need to be replaced?

\begin{tabular}{|l|l|l|}
\hline YES & NO & EXPLANATION (required if shaded box is checked) \\
\hline & & \\
\hline & & $\begin{array}{l}3 \text { of the UR sigens are down and I UR sign } \\
\text { is missing that needs to be replaced. }\end{array}$ \\
\hline & & \\
\hline
\end{tabular}




\begin{tabular}{|c|c|c|c|}
\hline \multicolumn{4}{|c|}{ POST-CLOSURE INSPECTION CHECKLIST } \\
\hline \multicolumn{4}{|c|}{ CAU 542: DISPOSAL HOLES - CAS 06-20-03, UD-6 AND UD-6S DISPOSAL HOLES } \\
\hline \multirow{2}{*}{$\begin{array}{l}\text { 2. Photograph Documentation (optional): } \\
\text { a. Have photographs been taken of the site? }\end{array}$} & YES & NO & EXPLANATION \\
\hline & & & \\
\hline If yes, how many photos were taken? & \multicolumn{2}{|c|}{3} & \\
\hline If yes, has a photographic log been prepared? & $\checkmark$ & & Log number: $I M G_{-} 0791-I M G_{-} 0793$ \\
\hline E. FIELD CONCLUSIONS & YES & NO & EXPLANATION (required if shaded box is checked) \\
\hline \multicolumn{4}{|l|}{ 1. Are more frequent inspections required? } \\
\hline \multicolumn{4}{|l|}{ 2. Are existing maintenance/repair actions satisfactory? } \\
\hline 3. Is other maintenance/repair necessary? & $\checkmark$ & & $\begin{array}{l}\text { Three signs that were noticed down need to } \\
\text { be rehung. }\end{array}$ \\
\hline \multicolumn{4}{|c|}{$\begin{array}{l}\text { 4. Field conclusions/recommendations: Noticed three UR signs down that need to be } \\
\text { rehung. The } U R \text { sigus are legible and well-maintained. Noticed } / U R \\
\text { sign missing that will be replaced with a new UR sign. }\end{array}$} \\
\hline \multicolumn{4}{|l|}{ F. CERTIFICATION } \\
\hline \multicolumn{4}{|c|}{$\begin{array}{l}\text { I have conducted an inspection of CAS 06-20-03, UD-6 and UD-6s Disposal Holes, in accordance with the procedures of the Post-Closure Plan as recorded } \\
\text { on this checklist, attached sheets, field notes, photographs, and photograph logs. }\end{array}$} \\
\hline \multicolumn{2}{|l|}{ Chief Inspector's Signature: /s/ G Richardson } & Date: & $11 / 04 / 08$ \\
\hline Printed Name: Glenn Richardson & & Title: & Task Manager \\
\hline
\end{tabular}


CAU 543: LIQUID DISPOSAL UNITS 
THIS PAGE INTENTIONALLY LEFT BLANK 


\section{POST-CLOSURE INSPECTION CHECKLIST}

\section{CAU 543: LIQUID DISPOSAL UNITS - CAS 06-07-01, DECON PAD}

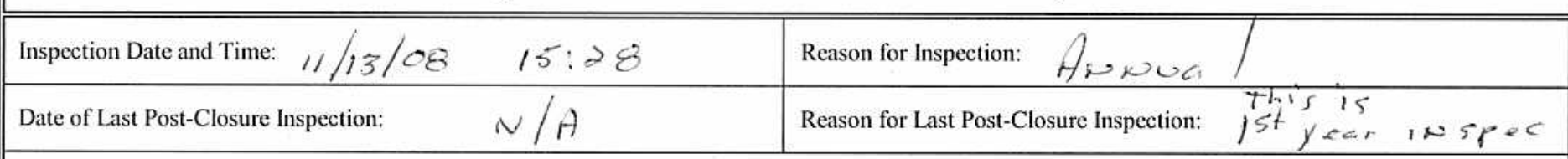

Responsible Entity: NSTec Environmental Restoration, Nevada Test Site, Mercury, Nevada

Responsible Facility Owner: Thomas A. Thiele, Project Manager, Industrial Sites, Environmental Restoration Project

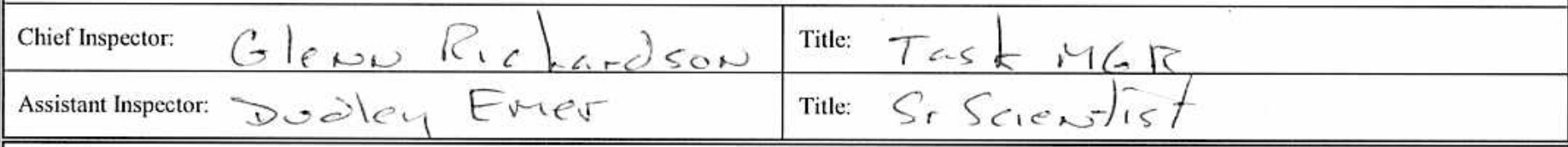

A. GENERAL INSTRUCTIONS

1. All checklist items must be completed and detailed comments made to document the results of the site inspection. The completed checklist is part of the field record of the inspection. Additional pages should be used as necessary to ensure that a complete record is made. Attach the additional pages and number all pages upon completion of the inspection.

2. Any checklist line item marked by an inspector in a SHADED BOX must be fully explained or an appropriate reference to previous reports provided. The purpose of this requirement is to provide a written explanation of inspector observations and the inspector's rationale for conclusions and recommendations. Explanations are to be placed on additional attachments and cross-referenced appropriately. Explanations, in addition to narrative, will take the form of sketches, measurements, and annotated site maps.

3. The site inspection is a walking inspection of the entire site including the perimeter and sufficient transects to be able to inspect the entire surface and all features specifically described in this checklist.

4. Field notes taken to assist in completion of this checklist will become part of the inspection record. No form is specified for field notes; however, they must be legible and in sufficient detail to enable review by succeeding inspectors and the responsible agency.

5. This unit will be inspected annually with formal reporting to the Nevada Division of Environmental Protection to be done annually. The annual letter report will include a summary with this inspection checklist attached.

\begin{tabular}{|l|l|l|l|}
\hline \hline B. PREPARATION (To be competed prior to site visit) & YES & NO & EXPLANATION (required if shaded box is checked) \\
\hline 1. Has the Post-Closure Plan been reviewed? & & & \\
2. Have the previous inspection reports been reviewed? & & &
\end{tabular}

\section{SITE INSPECTION PREPARATION}

Assemble the following, as needed, to conduct inspections:

a. Radio, pager, etc.

b. Previous letter report, inspection checklists, repair records, and as-built plans

c. Other miscellaneous support equipment

\section{SITE INSPECTION}

1. Site markers:

a. Is there damage to the fence?

b. Have any posts been damaged or their anchoring weakened?

c. Are any of the nine (9) use restriction signs damaged or missing?

d. Are all use restriction signs legible?

e. How many use restriction signs need to be replaced?

f. Are any of the nine (9) PCB signs damaged or missing?

\begin{tabular}{|l|l|l||}
\hline YES & NO & EXPLANATION (required if shaded box is checked) \\
\hline & & \\
\hline & & \\
\hline & & \\
\hline & & \\
\hline & & \\
\hline & & \\
\hline
\end{tabular}




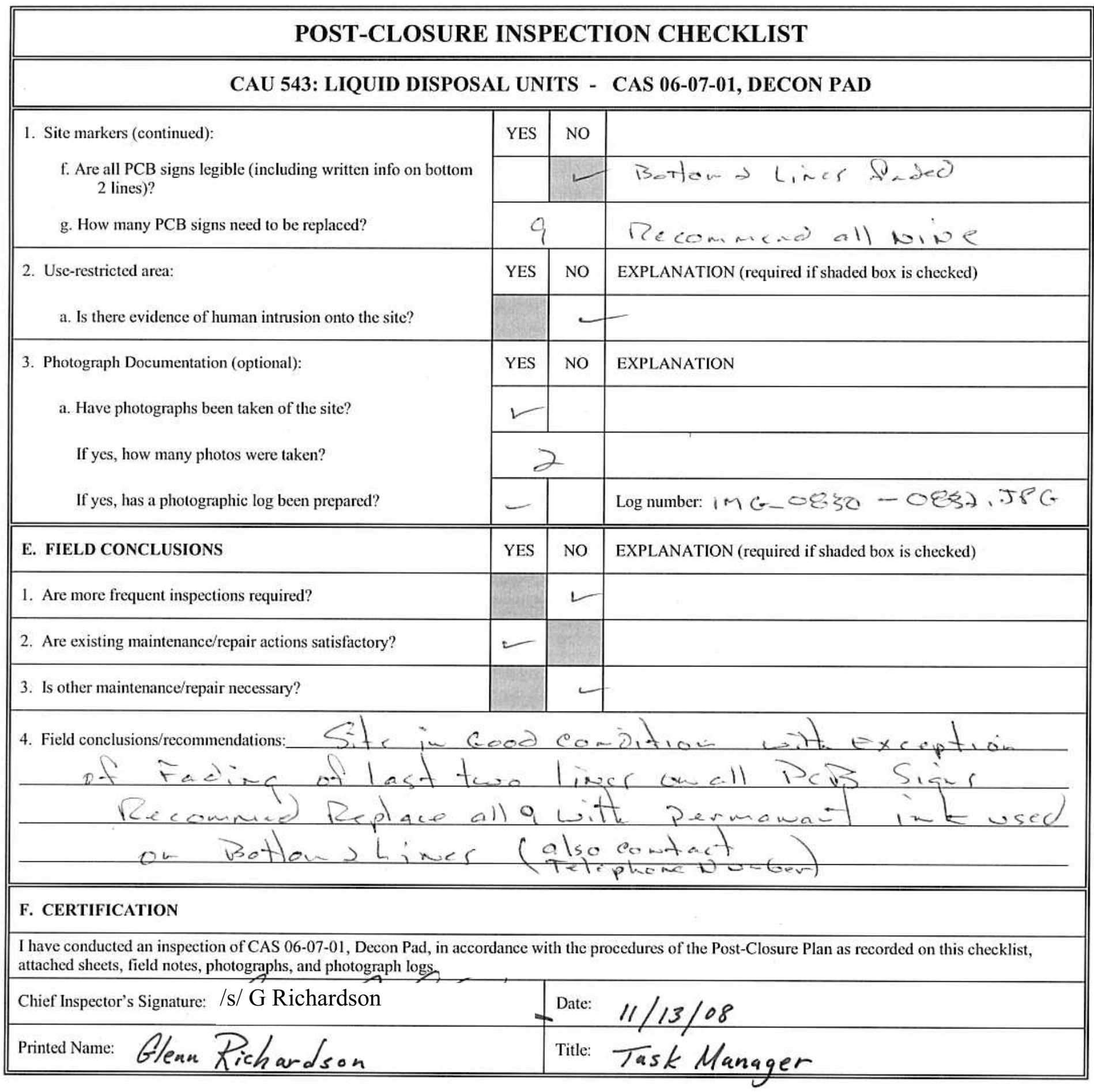




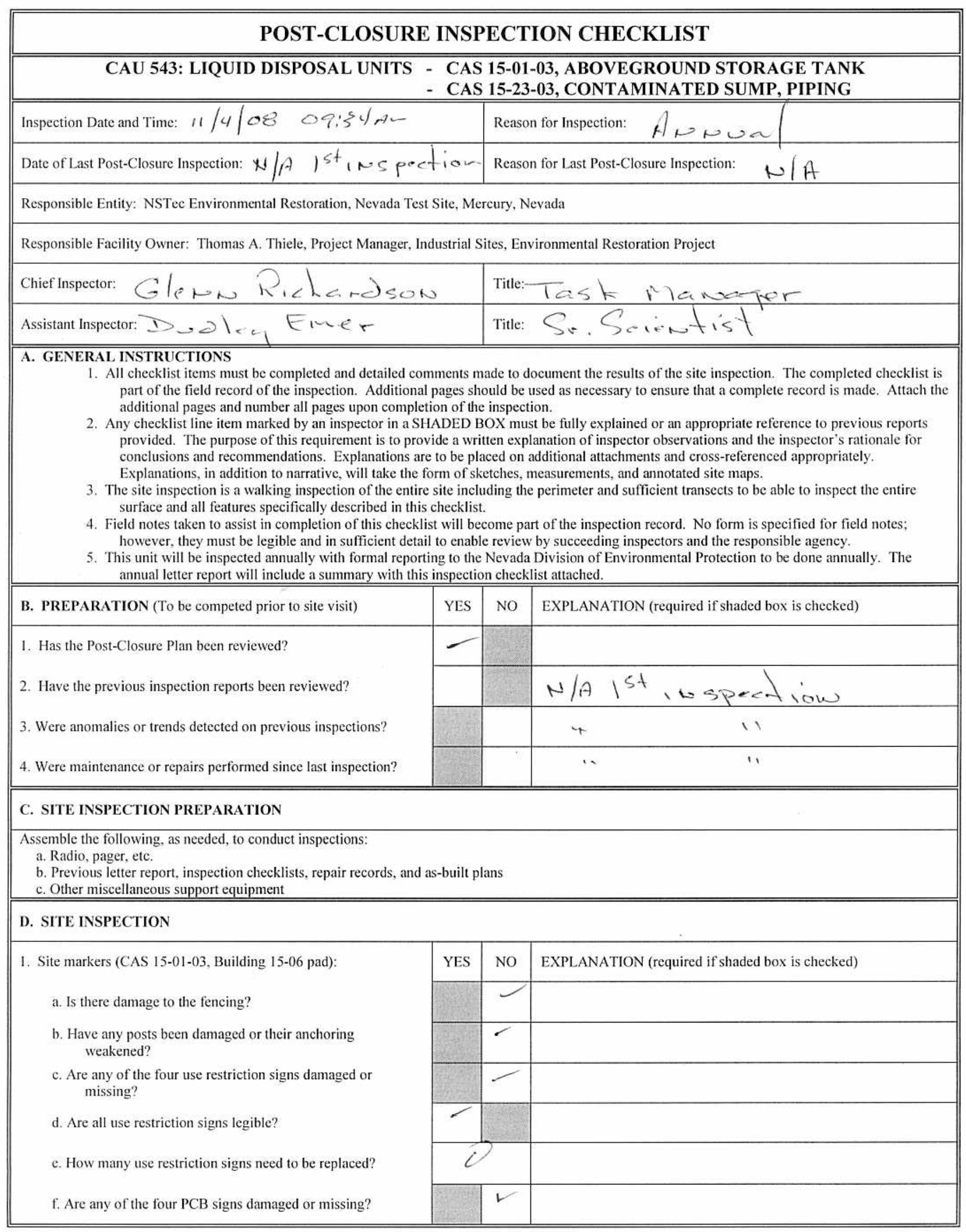




\section{POST-CLOSURE INSPECTION CHECKLIST \\ CAU 543: LIQUID DISPOSAL UNITS - CAS 15-01-03, ABOVEGROUND STORAGE TANK \\ - CAS 15-23-03, CONTAMINATED SUMP, PIPING}

1. Site markers (CAS 15-01-03, Bldg 15-06 pad) continued:

g. Are all PCB signs legible (including written info on bottom 2 lines)?

h. How many PCB signs need to be replaced?

2. Use-restricted area (CAS 15-01-03, Bldg. 15-06 pad):

a. Is there evidence of human intrusion onto the site?

3. Site markers (CAS 15-01-03, underground piping):

a. Have any posts been damaged or their anchoring weakened?

b. Are any of the twelve use restriction signs damaged or missing?

c. Are all use restriction signs legible?

d. How many use restriction signs need to be replaced?

e. Are any of the twelve PCB signs damaged or missing?

f. Are all PCB signs legible (including written info on bottom 2 lines)?

g. How many PCB signs need to be replaced?

4. Use-restricted area (CAS 15-01-03, underground piping):

a. Is there evidence of human intrusion onto the site?

5. Site markers (CAS 15-23-03):

a. Have any posts been damaged or their anchoring weakened?

b. Are any of the five use restriction signs damaged or missing?

c. Are all use restriction signs legible?

d. How many use restriction signs need to be replaced?

e. Are any of the four URMA signs damaged or missing?

f. Are all URMA signs legible?

g. How many URMA signs need to be replaced?

h. Are all URMA signs firmly affixed to fencing??

6. Use-restricted area (CAS 15-23-03):

a. Is there evidence of human intrusion onto the site?

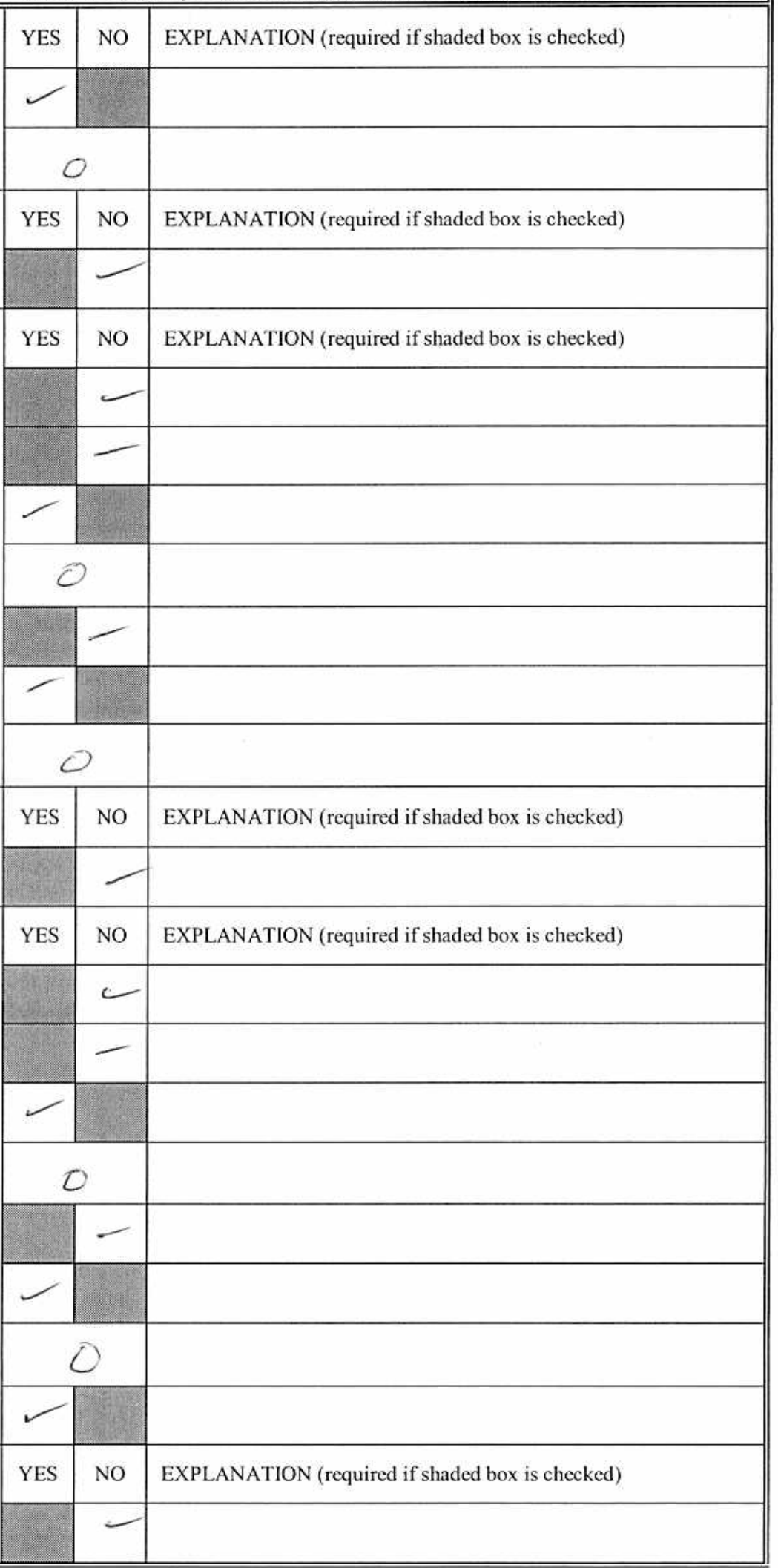




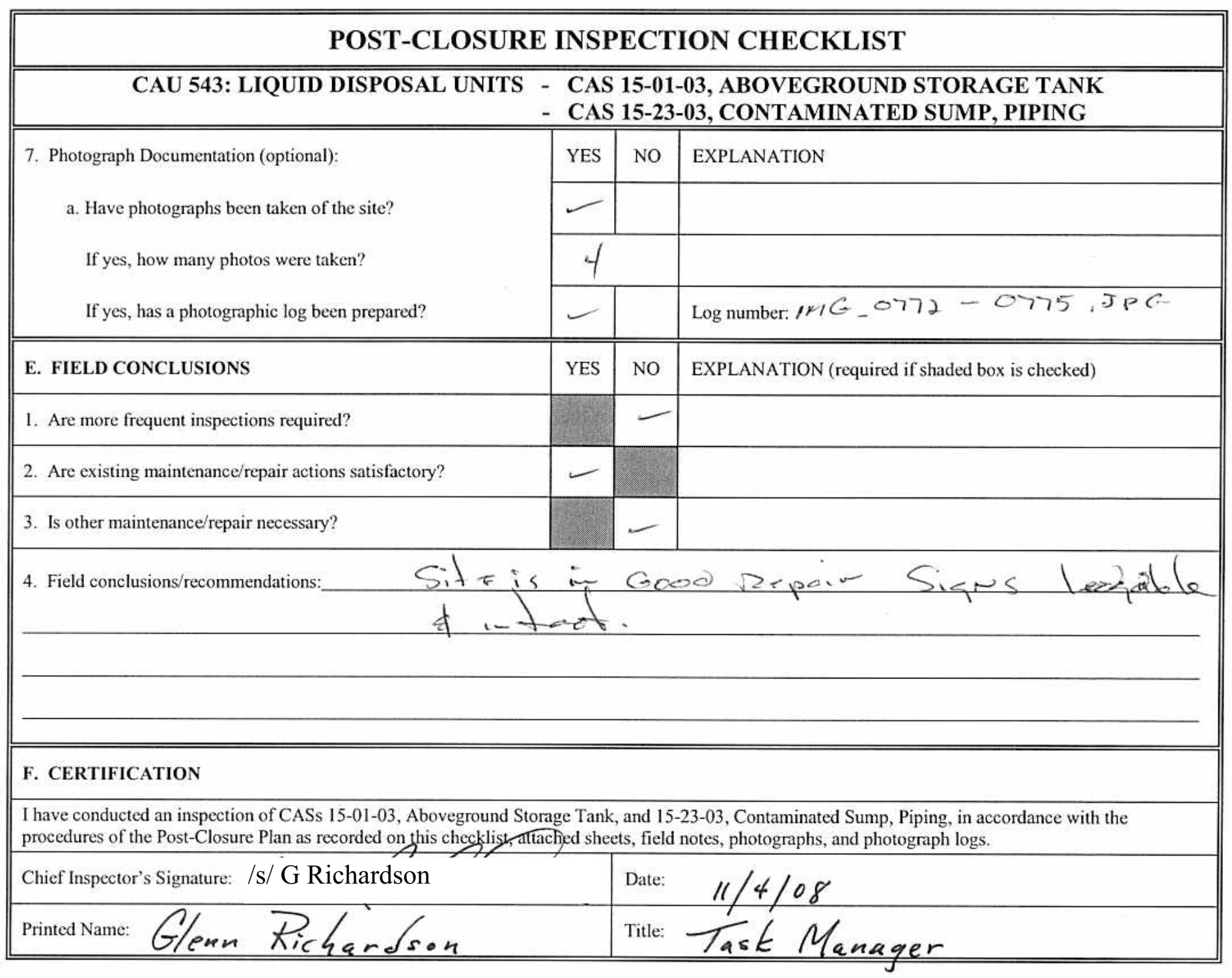


THIS PAGE INTENTIONALLY LEFT BLANK 
CAU 545: DUMPS, WASTE DISPOSAL SITES, AND BURIED RADIOACTIVE MATERIALS 
THIS PAGE INTENTIONALLY LEFT BLANK 


\section{POST-CLOSURE INSPECTION CHECKLIST}

\section{CAU 545: DUMPS, WASTE DISPOSAL SITES, AND BURIED RADIOACTIVE MATERIALS CAS 03-08-03, MUD DISPOSAL SITE}

\begin{tabular}{||l|l|}
\hline \hline Inspection Date and Time: $11 / 4 / 08 \quad 2: 12 \mathrm{PM}$ & Reason for Inspection: Annual \\
\hline Date of Last Post-Closure Inspection: None - /st Inspection & Reason for Last Post-Closure Inspection: /st inspection \\
\hline
\end{tabular}

Responsible Entity: NSTec Environmental Restoration, Nevada Test Site, Mercury, Nevada

Responsible Facility Owner: Thomas A. Thiele, Project Manager, Industrial Sites, Environmental Restoration Project

\begin{tabular}{l|l}
\hline Chief Inspector: Glenn Richardson & Title: Task Manager \\
\hline Assistant Inspector: Dudley Emer & Title: Sr. Seientist \\
\hline \hline
\end{tabular}

\section{A. GENERAL INSTRUCTIONS}

- Complete all checklist items.

- If a SHADED BOX is checked, provide detailed information regarding what was found and/or appropriate references to other documents that have the information (e.g., Maintenance Order Form for CAS 25-01-07 dated 3/28/2008).

- All documentation must be legible and clear.

\section{B. PREPARATION (To be competed prior to site visit)}

1. Has the Post-Closure Plan been reviewed?

2. Have the previous inspection reports been reviewed?

3. Were anomalies or trends detected on previous inspections?

4. Were maintenance or repairs performed since last inspection?

\begin{tabular}{|l|l|l||}
\hline YES & NO & EXPLANATION (required if shaded box is checked) \\
\hline & & \\
\hline & & $N / A-/$ st inspection \\
\hline & & $N / A-" ~$ \\
\hline & & $N / A-\|$ \\
\hline
\end{tabular}

\section{SITE INSPECTION PREPARATION}

Assemble the following, as needed, to conduct inspections:
a. Radio, pager, etc.
b. Camera, digital storage drive, and extra batteries
c. Previous Post-Closure Report, Inspection Checklists, repair records, and as-built plans
d. Tape measure
e. Other miscellaneous support equipment

\section{SITE INSPECTION}

- The site inspection is to ensure that postings are in place, intact, and readable. The checklist should be completed during the site inspection.

- If a shaded box is checked, add detailed comments to document the results of the site inspection. Information provided should be of sufficient detail to enable reconstruction of observations regarding field conditions. Information can take the form of written narrative, sketches, measurements, and annotated site maps, all of which should be placed on additional attachments (if needed) and cross-reference appropriately. Attach the additional pages and number all pages upon completion of the inspection. The completed checklist is part of the field record of the inspection.

- Field notes taken to assist in completion of this checklist will become part of the inspection record. No form is specified for field notes, and additional field notes are not required if the checklist and associated attachments adequately describe site conditions.

1. Site markers:

a. Is the fence damaged?

b. Have any posts been damaged or their anchoring weakened?

\begin{tabular}{|l|l|l||} 
YES & NO & EXPLANATION (required if shaded box is checked) \\
\hline & & \\
\hline & & \\
\hline
\end{tabular}




\section{POST-CLOSURE INSPECTION CHECKLIST}

\section{CAU 545: DUMPS, WASTE DISPOSAL SITES, AND BURIED RADIOACTIVE MATERIALS CAS 03-08-03, MUD DISPOSAL SITE}

1. Site markers (continued):

c. Are any of the fourteen (14) use restriction signs damaged or missing?

d. Are all use restriction signs legible?

e. Do all signs have the required wording on the signs (check wording on all signs):

WARNING
Radiologically Contaminated Area
FFACO Site CAU 545/CAS 03-08-03
CAS 03-08-03 Mud Disposal Site
No activities that alter or modify the containment control
are permitted without U.S. Government permission.
Before working in this area,
Contact Real Estate Services at 295-2528

f. How many signs need to be replaced?

\begin{tabular}{|c|c|c||}
\hline YES & NO & EXPLANATION (required if shaded box is checked) \\
\hline & & \\
\hline & & \\
\hline & & \\
& \\
\hline
\end{tabular}

Photograph Instructions:

- Photographs should be taken to document maintenance/repair needs at the site. These will be used to plan maintenance/repair activities and are not intended for use in the post-closure annual report.

- Anomalous features or new features (such as changes in adjacent area land use) should be photographed.

- Other photographs are optional.

- A photograph log entry will be made for each photograph taken.

2. Photograph Documentation:

a. Have photographs been taken of the site?

If yes, how many photos were taken?

If yes, has a photographic log been prepared?

\begin{tabular}{|c|c|c|}
\hline YES & NO & EXPLANATION \\
\hline & & \\
\hline YES & NO & EXPLANATION (required if shaded box is checked) \\
\hline & & $N / A$ - Ist inspection - Maintenance has not \\
\hline & & If "yes", describe in Field conclusions/recommendations \\
\hline
\end{tabular}

3. Are maintenance/repair actions necessary?

4. Field conclusions/recommendations: The UR signage and fencing are in good condition. There is no evidence of intrusion. The site perimeter overlaps into a contamination area. The radiological signage and postings are well maintained and in great condition. There are no issues that warrant a follow.up action. 


\begin{tabular}{|c|c|}
\hline \multicolumn{2}{|c|}{ POST-CLOSURE INSPECTION CHECKLIST } \\
\hline \multicolumn{2}{|c|}{$\begin{array}{l}\text { CAU 545: DUMPS, WASTE DISPOSAL SITES, AND BURIED RADIOACTIVE MATERIALS } \\
\text { CAS 03-08-03, MUD DISPOSAL SITE }\end{array}$} \\
\hline \multicolumn{2}{|l|}{ F. CERTIFICATION } \\
\hline \multicolumn{2}{|c|}{$\begin{array}{l}\text { I have conducted an inspection of CAS 03-08-03, Mud Disposal Site, in accordance with the procedures of the Post-Closure Plan as recorded on this } \\
\text { checklist, attached sheets, field notes, photographs, and photograph logs. }\end{array}$} \\
\hline Chicf Inspector's Signature: /s/ G Richardson & Date: $\quad 11 / 4 / 08$ \\
\hline Printed Name: Glenn Pichardson & Title: Task Manager \\
\hline
\end{tabular}

Required Attachments:

- Field Notes (if any)

Distribution: Original - Industrial Sites Project Manager

Copy - Task Manager

\section{G. VERIFICATION}

I have reviewed this checklist and attachments and have verified that it is complete.

\begin{tabular}{|l|l}
\hline Signature: /s/ R Poderis & Date: $1-20-09$
\end{tabular}

Printed Name: Thomas A. [thiele (or designee) Reed Poderis

Distribution: Original - Task Manager 


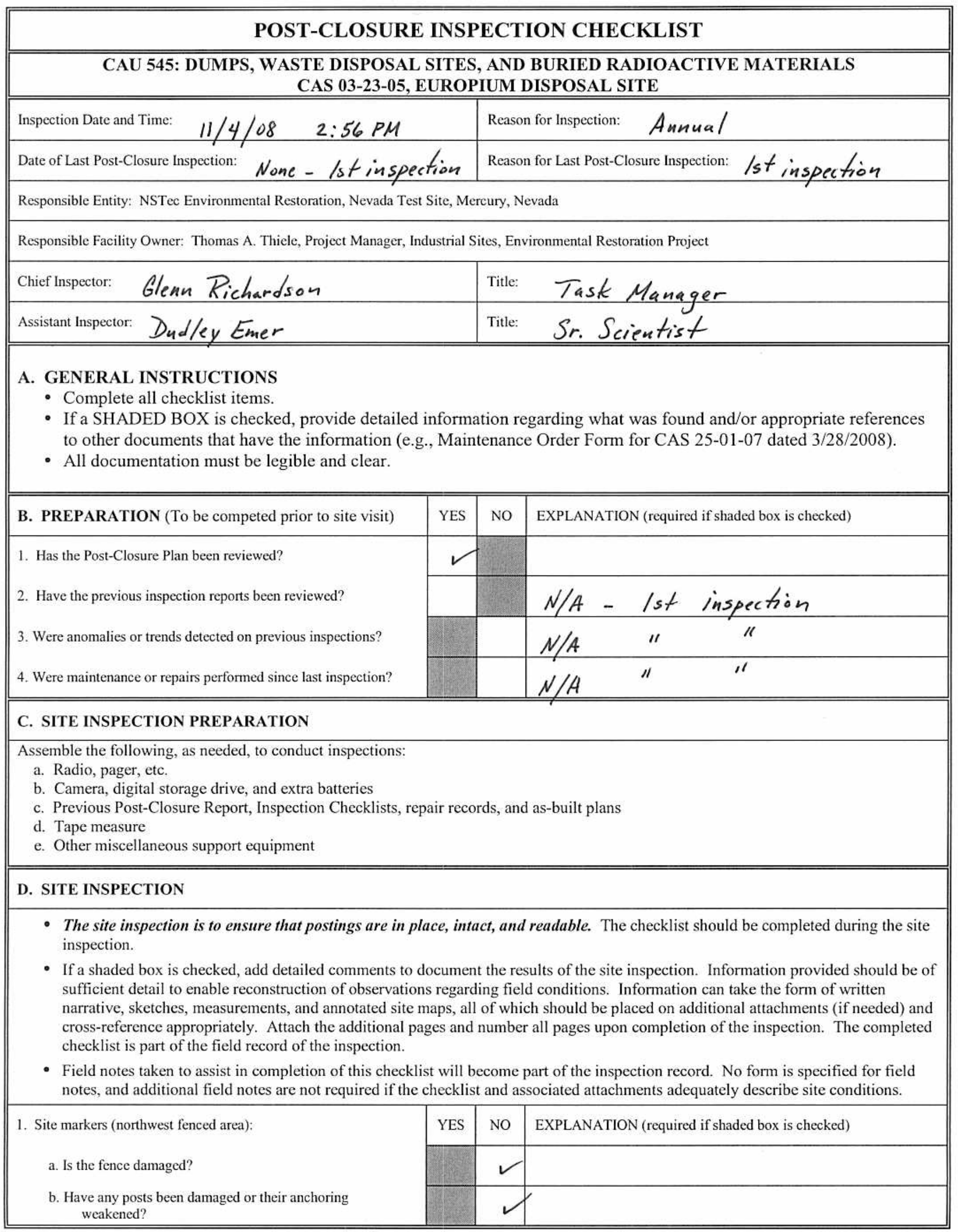




\begin{tabular}{|c||}
\hline POST-CLOSURE INSPECTION CHECKLIST \\
\hline \hline CAU 545: DUMPS, WASTE DISPOSAL SITES, AND BURIED RADIOACTIVE MATERIALS \\
CAS 03-23-05, EUROPIUM DISPOSAL SITE \\
\hline \hline
\end{tabular}

1. Site markers (northwest fenced area), continued:

c. Are any of the four (4) use restriction signs damaged or missing??

d. Are all use restriction signs legible?

e. Do all signs have the required wording on the signs (check wording on all signs):

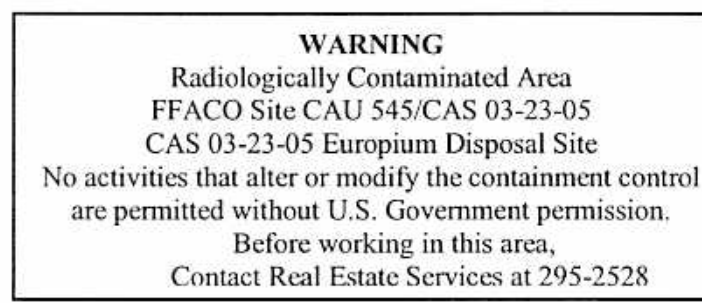

f. How many signs need to be replaced?

2. Site markers (southern fenced area):

a. Is the fence damaged?

b. Have any posts been damaged or their anchoring weakened?

c. Are any of the three (3) use restriction signs damaged or missing??

d. Are all use restriction signs legible?

e. Do all signs have the required wording on the signs (check wording on all signs):

\begin{tabular}{|c|} 
WARNING \\
Radiologically Contaminated Area \\
FFACO Site CAU 545/CAS 03-23-05 \\
CAS 03-23-05 Europium Disposal Site \\
No activities that alter or modify the containment control \\
are permitted without U.S. Government permission. \\
Before working in this area, \\
Contact Real Estate Services at 295-2528
\end{tabular}

f. How many signs need to be replaced?

\begin{tabular}{|l|l|l||}
\hline YES & NO & EXPLANATION (required if shaded box is checked) \\
\hline & & \\
\hline & & \\
\hline & & \\
\hline & & \\
\hline YES & NO & EXPLANATION (required if shaded box is checked) \\
\hline & & \\
\hline & & \\
\hline & & \\
\hline & & \\
\hline & & \\
\hline & & \\
\hline & & \\
\hline & & \\
\hline & & \\
\hline & & \\
\hline & & \\
\hline
\end{tabular}

Photograph Instructions:

- Photographs should be taken to document maintenance/repair needs at the site. These will be used to plan maintenance/repair activities and are not intended for use in the post-closure annual report.

- Anomalous features or new features (such as changes in adjacent area land use) should be photographed.

- Other photographs are optional.

- A photograph log entry will be made for each photograph taken.

3. Photograph Documentation:

a. Have photographs been taken of the site?

If yes, how many photos were taken?

If yes, has a photographic $\log$ been prepared?

\begin{tabular}{|c|l|l||}
\hline YES & NO & EXPLANATION \\
\hline \multicolumn{1}{|c||}{} & & \\
\hline 2 & \\
\hline & & \\
\hline
\end{tabular}




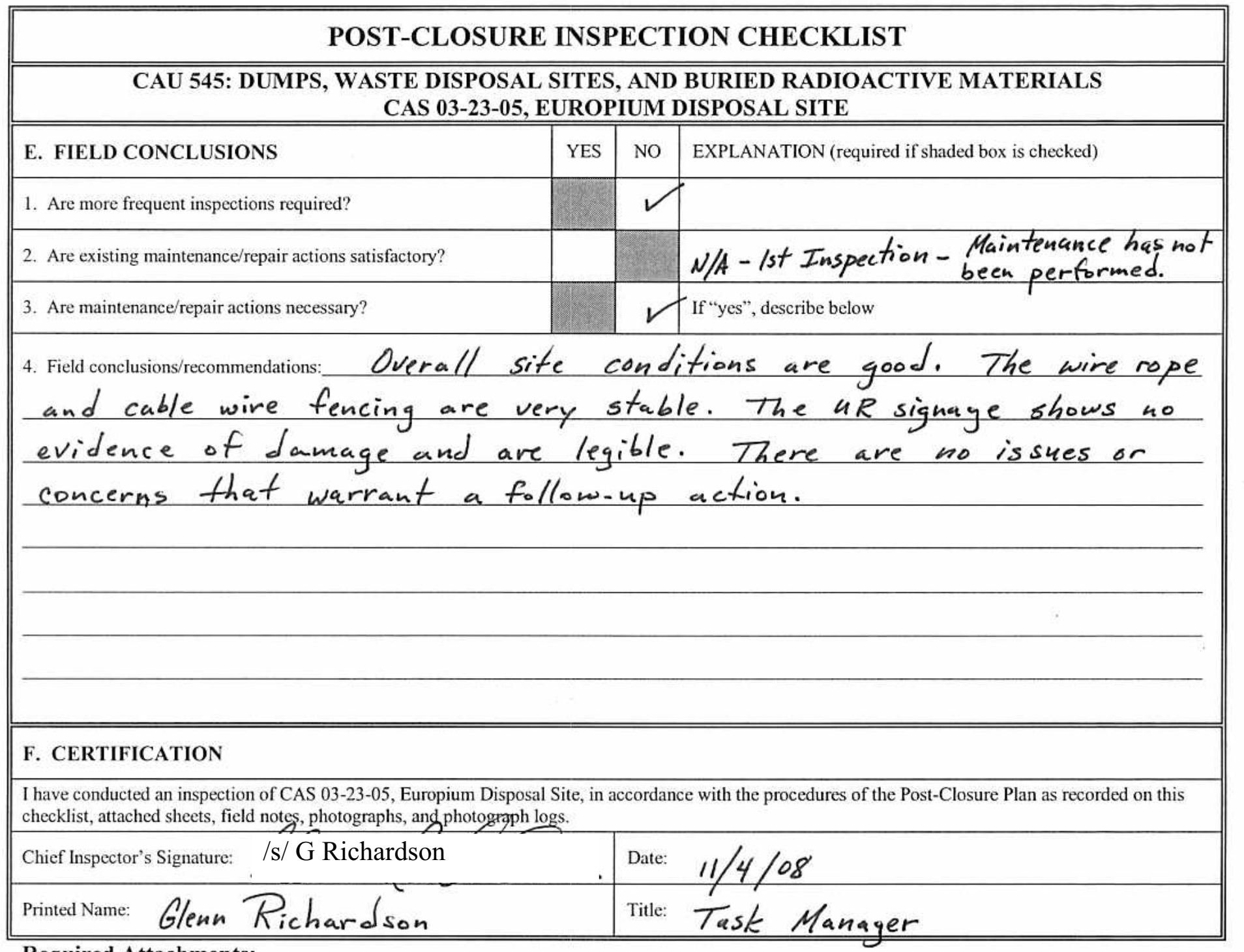

\section{Required Attachments:}

- Field Notes (if any)

Distribution: Original - Industrial Sites Project Manager

Copy - Task Manager

\section{G. VERIFICATION}

I have reviewed this checklist and attachments and have verified that it is complete.

\begin{tabular}{l|l|l} 
Signature: /s/ R Poderis & Date: $1-20-09$
\end{tabular}

Printed Name: Thomas A. Thiele (or designee) Peed Pode is

Distribution: Original - Task Manager 
CAU 551: AREA 12 MUCKPILES 
THIS PAGE INTENTIONALLY LEFT BLANK 


\section{POST-CLOSURE INSPECTION CHECKLIST}

\section{CAU 551: AREA 12 MUCKPILES - CAS 12-01-09, ABOVEGROUND STORAGE TANK AND STAIN \\ CAS 12-06-05, U-12B MUCKPILE \\ CAS 12-06-07, MUCKPILE \\ CAS 12-06-08, MUCKPILE}

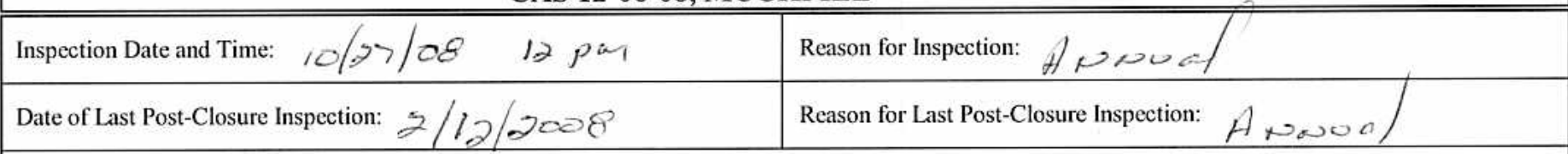

Responsible Entity: NSTec Environmental Restoration, Nevada Test Site, Mercury, Nevada

Responsible Facility Owner: Thomas A. Thiele, Project Manager, Industrial Sites, Environmental Restoration Project

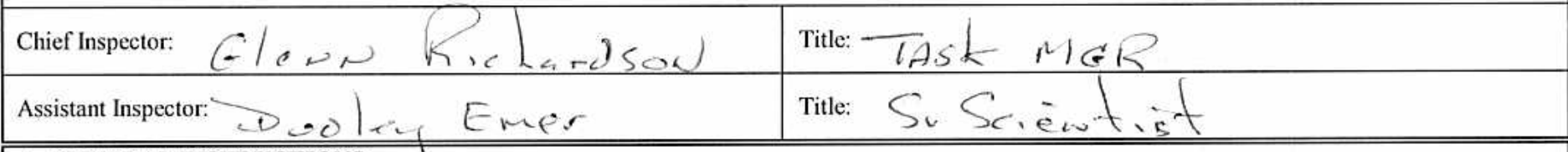

A. GENERAL INSTRUCTIONS

1. All checklist items must be completed and detailed comments made to document the results of the site inspection. The completed checklist is part of the field record of the inspection. Additional pages should be used as necessary to ensure that a complete record is made. Attach the additional pages and number all pages upon completion of the inspection.

2. Any checklist line item marked by an inspector in a SHADED BOX must be fully explained or an appropriate reference to previous reports provided. The purpose of this requirement is to provide a written explanation of inspector observations and the inspector's rationale for conclusions and recommendations. Explanations are to be placed on additional attachments and cross-referenced appropriately.

Explanations, in addition to narrative, will take the form of sketches, measurements, and annotated site maps.

3. The site inspection is a walking inspection of the entire site including the perimeter and sufficient transects to be able to inspect the entire surface and all features specifically described in this checklist.

4. Field notes taken to assist in completion of this checklist will become part of the inspection record. No form is specified for field notes; however, they must be legible and in sufficient detail to enable review by succeeding inspectors and the responsible agency.

5. This unit will be inspected annually with formal reporting to the Nevada Division of Environmental Protection to be done annually. The annual letter report will include a summary with this inspection checklist attached.

B. PREPARATION (To be competed prior to site visit)

1. Has the Post-Closure Plan been reviewed?

2. Have the previous inspection reports been reviewed?

3. Were anomalies or trends detected on previous inspections?

4. Were maintenance or repairs performed since last inspection?

\begin{tabular}{|c|c|c|}
\hline YES & NO & EXPLANATION (required if shaded box is checked) \\
\hline$\checkmark$ & & \\
\hline ᄂ & & \\
\hline & & \\
\hline 2 & & ore Siju Re harg \\
\hline
\end{tabular}

\section{SITE INSPECTION PREPARATION}

Assemble the following, as needed, to conduct inspections:

a. Radio, pager, etc.

b. Previous letter report, inspection checklists, repair records, and as-built plans

c. Other miscellaneous support equipment

\section{SITE INSPECTION}

1. Site markers:

a. Have any posts been damaged or their anchoring weakened?

b. Are any of the 13 use restriction signs damaged or missing?

c. Are all use restriction signs legible?

d. How many signs need to be replaced?

\begin{tabular}{|l|l|l||} 
YES & NO & EXPLANATION (required if shaded box is checked) \\
\hline & $\checkmark$ & \\
\hline & $\checkmark$ & \\
\hline & & \\
\hline
\end{tabular}




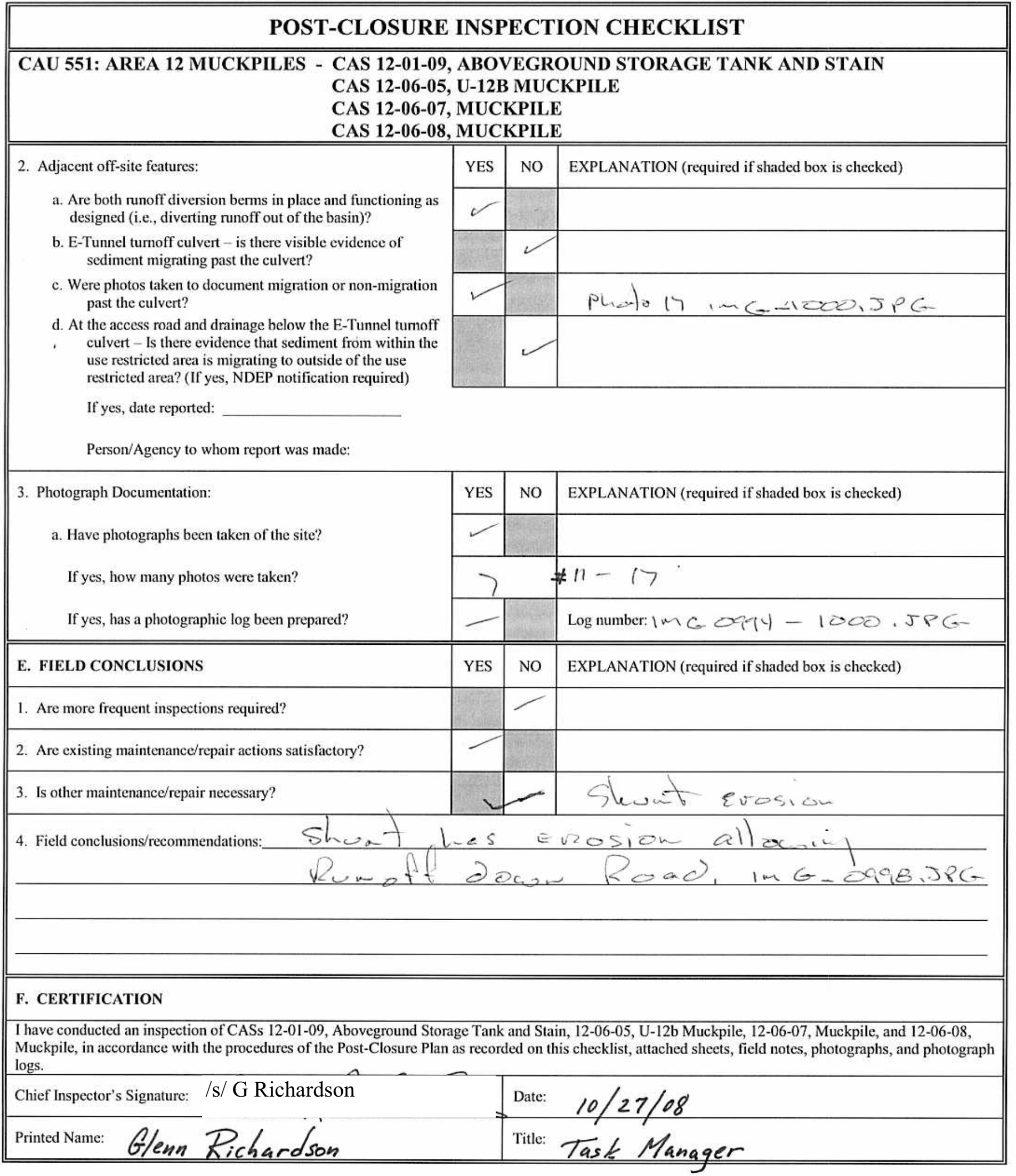

Attachments (check if attached):

$\square$ Photos 
CAU 552: AREA 12 MUCKPILE AND PONDS 
THIS PAGE INTENTIONALLY LEFT BLANK 


\section{POST-CLOSURE INSPECTION CHECKLIST}

\section{CAU 552: AREA 12 MUCKPILE AND PONDS - CAS 12-23-05, PONDS}

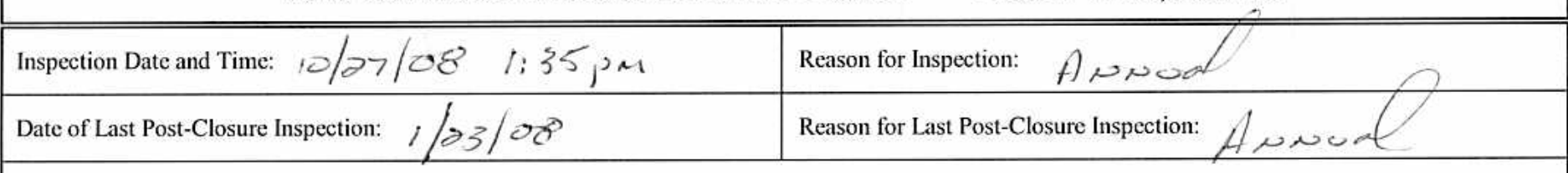

Responsible Entity: NSTec Environmental Restoration, Nevada Test Site, Mercury, Nevada

Responsible Facility Owner: Thomas A. Thiele, Project Manager, Industrial Sites, Environmental Restoration Project

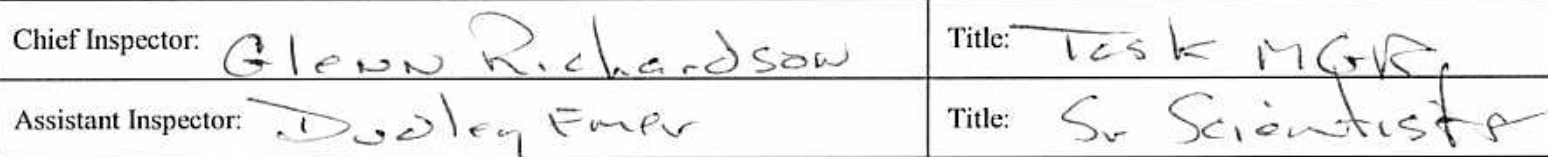

A. GENERAL INSTRUCTIONS

1. All checklist items must be completed and detailed comments made to document the results of the site inspection. The completed checklist is part of the field record of the inspection. Additional pages should be used as necessary to ensure that a complete record is made. Attach the additional pages and number all pages upon completion of the inspection.

2. Any checklist line item marked by an inspector in a SHADED BOX must be fully explained or an appropriate reference to previous reports provided. The purpose of this requirement is to provide a written explanation of inspector observations and the inspector's rationale for conclusions and recommendations. Explanations are to be placed on additional attaclments and cross-referenced appropriately. Explanations, in addition to narrative, will take the form of sketches, measurements, and annotated site maps.

3. The site inspection is a walking inspection of the entire site including the perimeter and sufficient transects to be able to inspect the entire surface and all features specifically described in this checklist.

4. Field notes taken to assist in completion of this checklist will become part of the inspection record. No form is specified for field notes; however, they must be legible and in sufficient detail to enable review by succeeding inspectors and the responsible agency.

5. This unit will be inspected annually with formal reporting to the Nevada Division of Environmental Protection to be done annually. The annual letter report will include a summary with this inspection checklist attached.

B. PREPARATION (To be competed prior to site visit)

1. Has the Post-Closure Plan been reviewed?

2. Have the previous inspection reports been reviewed?

3. Were anomalies or trends detected on previous inspections?

4. Were maintenance or repairs performed since last inspection?

5. Has the G-Tunnel muckpile been completed and source of contamination been controlled? (If yes, then additional postclosure activities may be needed. See the Closure Report.)

\begin{tabular}{|c|c|c|}
\hline YES & NO & EXPLANATION (required if shaded box is checked) \\
\hline & & \\
\hline$L$ & & \\
\hline & & . \\
\hline & & Borlocoin lience Depaiv \\
\hline & & . \\
\hline
\end{tabular}

\section{SITE INSPECTION PREPARATION}

Assemble the following, as needed, to conduct inspections:

a. Radio, pager, etc.

b. Previous letter report, inspection checklists, repair records, and as-built plans

c. Other miscellaneous support equipment

\section{SITE INSPECTION}

1. Site markers:

a. Is there damage to the fence or rope?

b. Have any posts been damaged or their anchoring weakened?

c. Are any of the radiological posting signs damaged or missing?

d. Are all radiological posting signs legible?

e. How many signs need to be replaced?

\begin{tabular}{|l|l|l||}
\hline YES & NO & EXPLANATION (required if shaded box is checked) \\
\hline & 4 & \\
\hline & 4 & \\
\hline & & \\
\hline & & \\
\hline
\end{tabular}




\begin{tabular}{|c|c|c|c|}
\hline \multicolumn{4}{|c|}{ POST-CLOSURE INSPECTION CHECKLIST } \\
\hline \multicolumn{4}{|c|}{ CAU 552: AREA 12 MUCKPILE AND PONDS - CAS 12-23-05, PONDS } \\
\hline \multirow{2}{*}{$\begin{array}{l}\text { 2. Photograph Documentation (optional): } \\
\text { a. Have photographs been taken of the site? }\end{array}$} & YES & NO & EXPLANATION \\
\hline & & & \\
\hline If yes, how many photos were taken? & \multicolumn{2}{|c|}{2} & $11,3,19$ \\
\hline If yes, has a photographic log been prepared? & \multicolumn{2}{|c|}{1} & 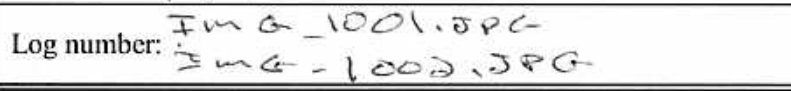 \\
\hline E. FIELD CONCLUSIONS & YES & NO & EXPLANATION (required if shaded box is checked) \\
\hline \multicolumn{2}{|l|}{ 1. Are more frequent inspections required? } & c & \\
\hline \multicolumn{2}{|l|}{ 2. Are existing maintenance/repair actions satisfactory? } & & \\
\hline \multicolumn{2}{|l|}{ 3. Is other maintenance/repair necessary? } & $山$ & \\
\hline \multicolumn{4}{|l|}{ 4. Field conclusions/recommendations: } \\
\hline \multicolumn{4}{|l|}{ F. CERTIFICATION } \\
\hline \multicolumn{4}{|c|}{$\begin{array}{l}\text { I have conducted an inspection of CAS 12-23-05, Ponds, in accordance with the procedures of the Post-Closure Plan as recorded on this checklist, attached } \\
\text { sheets, field notes, photographs, and photograph logs. }\end{array}$} \\
\hline \multicolumn{2}{|l|}{ Chief Inspector's Signature: / $/$ / G Richardson } & Date: & \\
\hline Printed Name: Glenn Fichardson & & Title: & Task Manager \\
\hline
\end{tabular}


CAU 554: AREA 23 RELEASE SITE 
THIS PAGE INTENTIONALLY LEFT BLANK 


\section{POST-CLOSURE INSPECTION CHECKLIST}

\section{CAU 554: AREA 23 RELEASE SITE - CAS 23-02-08, USTS 23-115-1,2,3/SPILL NO. 530-90-002}

\begin{tabular}{|l|l|}
\hline Inspection Date and Time: $/ / / 25 / 08 \quad 9: 06 \mathrm{AM}$ & Reason for Inspection: Annual \\
\hline Date of Last Post-Closure Inspection: $1 / 23 / 08$ & Reason for Last Post-Closure Inspection: Annua /
\end{tabular}

Responsible Entity: NSTec Environmental Restoration, Nevada Test Site, Mercury, Nevada

Responsible Facility Owner: Thomas A. Thiele, Project Manager, Industrial Sites, Environmental Restoration Project

\begin{tabular}{l|l} 
Chief Inspector: Glenn Fichardson & Title: Task Manager \\
\hline Assistant Inspector: Chris McGowin & Title: Field Technical Lead
\end{tabular}

\section{A. GENERAL INSTRUCTIONS}

1. All checklist items must be completed and detailed comments made to document the results of the site inspection. The completed checklist is part of the field record of the inspection. Additional pages should be used as necessary to ensure that a complete record is made. Attach the additional pages and number all pages upon completion of the inspection.

2. Any checklist line item marked by an inspector in a SHADED BOX must be fully explained or an appropriate reference to previous reports provided. The purpose of this requirement is to provide a written explanation of inspector observations and the inspector's rationale for conclusions and recommendations. Explanations are to be placed on additional attachments and cross-referenced appropriately. Explanations, in addition to narrative, will take the form of sketches, measurements, and annotated site maps.

3. The site inspection is a walking inspection of the entire site including the perimeter and sufficient transects to be able to inspect the entire surface and all features specifically described in this checklist.

4. Field notes taken to assist in completion of this checklist will become part of the inspection record. No form is specified for field notes; however, they must be legible and in sufficient detail to enable review by succeeding inspectors and the responsible agency.

5. This unit will be inspected annually with formal reporting to the Nevada Division of Environmental Protection to be done annually. The annual letter report will include a summary with this inspection checklist attached.

\begin{tabular}{|c|c|c|c|}
\hline B. PREPARATION (To be competed prior to site visit) & YES & NO & EXPLANATION (required if shaded box is checked) \\
\hline 1. Has the Post-Closure Plan been reviewed? & & & \\
\hline 2. Have the previous inspection reports been reviewed? & & & \\
\hline 3. Were anomalies or trends detected on previous inspections? & & & \\
\hline 4. Were maintenance or repairs performed since last inspection? & & & \\
\hline
\end{tabular}

\section{SITE INSPECTION PREPARATION}

Assemble the following, as needed, to conduct inspections:

a. Radio, pager, etc.

b. Previous letter report, inspection checklists, repair records, and as-built plans

c. Other miscellaneous support equipment

\section{SITE INSPECTION}

1. Site markers:

a. Are both brass plates intact and readable?

b. Have any posts been damaged or their anchoring weakened?

c. Are any of the 4 use restriction signs damaged or missing?

d. Are all use restriction signs legible?

e. How many signs need to be replaced?

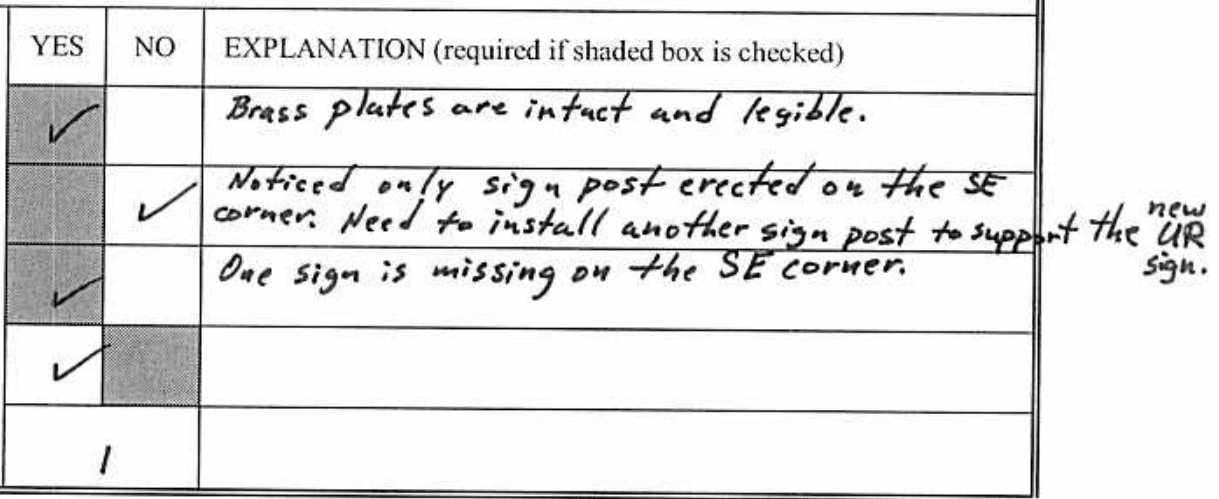




\section{POST-CLOSURE INSPECTION CHECKLIST}

\section{CAU 554: AREA 23 RELEASE SITE - CAS 23-02-08, USTS 23-115-1,2,3/SPILL NO. 530-90-002}

$\begin{aligned} & \text { 2. Photograph Documentation (optional): } \\ & \text { a. Have photographs been taken of the site? }\end{aligned}$
$\begin{aligned} & \text { If yes, how many photos were taken? } \\ & \text { If yes, has a photographic log been prepared? }\end{aligned}$

\section{F. CERTIFICATION}

I have conducted an inspection of CAS 23-02-08, USTs 23-115-1,2,3/Spill No. 530-90-002, in accordance with the procedures of the Post-Closure Plan as recorded on this checklist, attached sheets, field notes, photographs, and photograph logs.

\begin{tabular}{l|l}
\hline Chief Inspector's Signature: /s/ G Richardson & Date: $11 / 25 / 08$ \\
\hline Printed Name: Gleun Richardson & Title: Task Manager
\end{tabular} 